\section{НОВАЯ НАУКА}

Международный центр научного партнерства
NEW SCIENCE

International Center for Scientific Partnership

\author{
Т. Ю. Салова \\ Н. Ю. Громова
}

\title{
СТАБИЛИЗАЦИЯ СВОЙСТВ ТОПЛИВНО-ЭНЕРГЕТИЧЕСКИХ СИСТЕМ НА ОСНОВЕ ПРИРОДНЫХ И СИНТЕТИЧЕСКИХ ПОЛИМЕРОВ
}

\author{
Монография
}

г. Петрозаводск

МЦНП «Новая наука»

2021 
УДК 620.9

ББК 315

C16

\section{Авторы : \\ Салова Тамара Юрьевна \\ Громова Нина Юрьевна}

Рецензенты:

Беззубиева M.M., доктор технических наук, профессор, заведующая кафедрой Энергообеспечение предприятий и электротехнологии

Епифанов А.П., доктор технических наук, профессор кафедры Электроэнергетика и электрооборудование

\section{Салова, Тамара Юрьевна.}

С16 СТАБИЛИЗАЦИЯ СВОЙСТВ ТОПЛИВНО-ЭНЕРГЕТИЧЕСКИХ СИСТЕМ НА ОСНОВЕ ПРИРОДНЫХ И СИНТЕТИЧЕСКИХ ПОЛИМЕРОВ : монография / Т. Ю. Салова, Н. Ю. Громова. - Петрозаводск : МЦПП «Новая наука», 2021. - 224 с. : рис., табл.

ISBN 978-5-00174-312-5

Монография содержит теоретические основы и практические методы переработки органических отходов. Изложены научные принципы управления качеством природных и техногенных энергетических ресурсов. Разработаны научные основы методологии утилизации целлюлозосодержащих отходов и технологии получения возобновляемых энергетических ресурсов.

Книга адресована специалистам научно-исследовательских учреждений, инженерно-техническим работникам, обучающимся в высших учебных заведениях.

УДК 620.9

ББК 315

ISBN 978-5-00174-312-5

(С Салова Т.Ю., Громова Н.Ю., 2021

(C) МЦНП «Новая наука» (ИП Ивановская И.И.), оформление, 2021 


\section{ОГЛАВЛЕНИЕ}

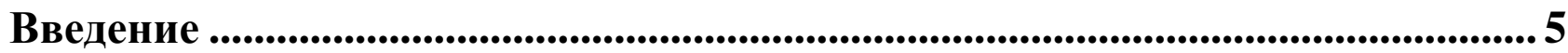

Глава 1. Инструментарии стабилизации качества природных и техногенных экосистем ........................................................................................8

1.1 Экологические основы безопасного функционирования природных экосистем. Концепция стабильного развития биосферы ....................................... 8

1.2 Методология мониторинга техногенных экосистем ................................... 12

1.2.1 Инструментарии химического мониторинга техногенных систем.............. 15

1.2.2 Производственный мониторинг лекарственных препаратов ....................... 20

1.2.3 Экологический мониторинг поверхностных вод в пределах

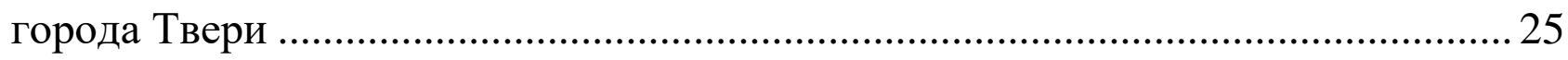

1.2.4 Биотестирование поверхностных вод и техногенных почв

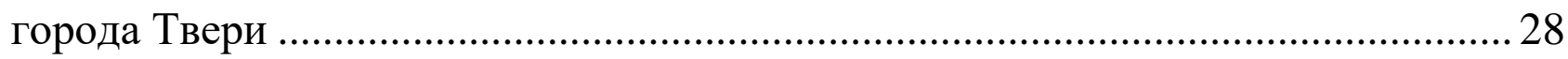

Глава 2. Методология стабилизации физико-химических свойств синтетических полимерных систем.................................................................39

2.1 Теоретические аспекты растворимости компонентов водоразбавляемых

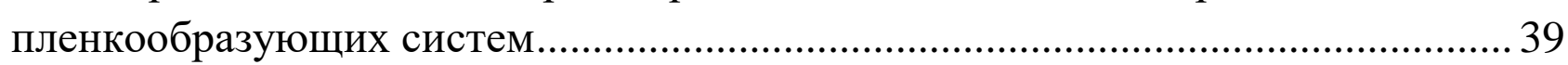

2.1.1 Особенности межмолекулярных взаимодействий низкомолекулярных

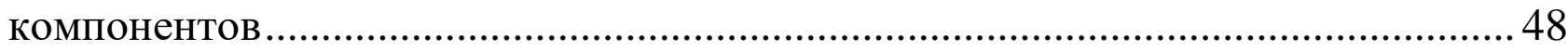

2.2 Отражение межмолекулярных взаимодействий низкомолекулярных компонентов на стабильность пленкообразующих систем ..................................5 52

2.2.1 Физико-химический анализ летучей части пленкообразующих систем .... 52

2.2.2 Фазовые равновесия в тройных системах с низкомолекулярными компонентами

2.2.3 Влияние эффективных гомогенизаторов на стабильность пленкообразующих систем.

2.2.3.1 Фазовые равновесия в бинарных и тройных системах с модельными олигоэфирами

2.2.3.2 Фазовые равновесия в системах с модифицированным олигоэфиром

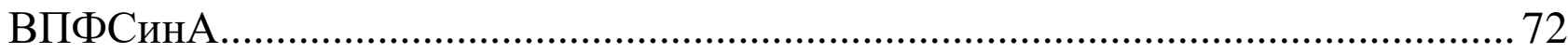

2.2.3.3 Фазовые равновесия в системах вода - ВМФ - растворитель................. 75

2.2.4 Влияние фазового состояния на реологию пленкообразующих систем .... 78

Глава 3. Методология оценки качества атмосферного воздуха

техногенных систем .................................................................................................................. 86

3.1 Физико-химические инструментарии стабильности экосистем...................... 86

3.2 Термодинамические инструментарии стабильности экосистем ..................... 96 
3.3 Моделирование образования продуктов деструкции жидкого

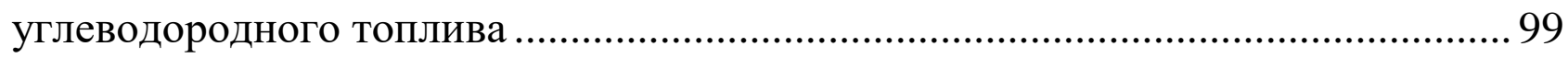

3.3.1 Теоретическое обоснование выбора модели горения углеводородов ...... 101

3.3.2 Термодинамическая модель образования оксидов азота .......................... 111

Глава 4. Методология деструкции синтетических и природных

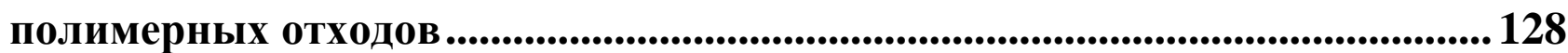

4.1 Теоретические аспекты утилизации полимерных отходов............................. 128

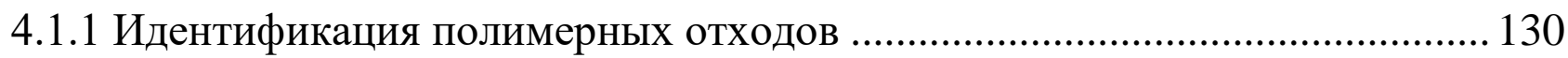

4.1.2 Состав и свойства синтетических и биополимерных отходов ................... 132

4.1.3 Современные инструментарии деструкции полимерных отходов ........... 140

4.2 Технологии утилизации углеродсодержащих биополимерных отходов .... 157

4.2.1 Разработка эффективной технологии биоконверсии твердых

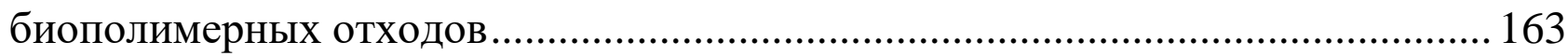

4.2.2 Оценка влияния параметров процесса биоконверсии твердых отходов на

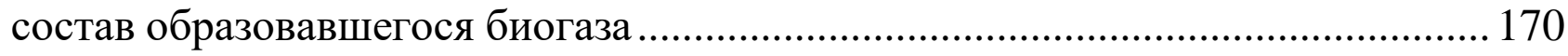

4.3 Модульные системы энергообеспечения................................................. 173

Глава 5. Теоретические аспекты рекультивации техногенных почв ........ 181

5.1 Почва как возобновляемый природный ресурс ............................................ 181

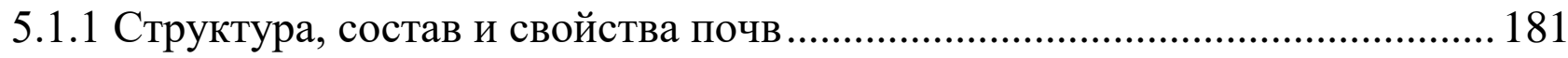

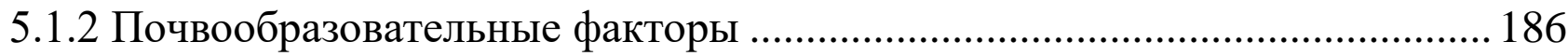

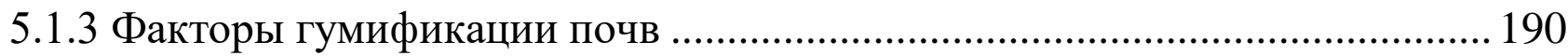

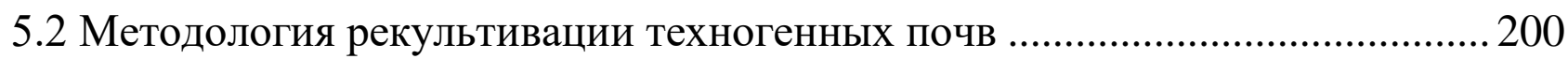

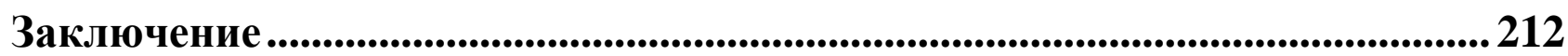

Список литературы........................................................................................................2213 


\section{СТАБИЛИЗАЦИЯ СВОЙСТВ ТОПЛИВНО-ЭНЕРГЕТИЧЕСКИХ СИСТЕМ НА ОСНОВЕ ПРИРОДНЫХ И СИНТЕТИЧЕСКИХ ПОЛИМЕРОВ}

\section{ВВЕДЕНИЕ}

В процессе развития цивилизации при взаимодействии человека со средой обитания изменились границы, качество и стабильность биосферы, природных экосистем, что привело к деградации природного ландшафта, снижению общей продуктивности живых организмов, замещению высших форм жизни низшими формами. Сформировались техносфера и агросфера, возникли опасности - токсичные техногенные отходы не свойственные природным экосистемам с длительным периодом полураспада, которые непосредственно или косвенно (через объекты окружающей среды) снижают качества пищевых продуктов, наносят вред здоровью человека. Более $70 \%$ ядов попадают в организм человека с пищей, $20 \%$ - с воздухом, $10 \%$ - с водой [1]. Смертность от несчастных случаев занимает третье место после смертности от сердечно сосудистых и онкологических заболеваний. Функционирование техносферы и агросферы увеличивает экологический риск от загрязнения атмосферы, гидросферы, литосферы. Наибольшую опасность для жизнедеятельности людей представляют крупнотоннажные техногенные отходы (II класс опасности) нефтехимической, химической, горнодобывающей, целлюлозной, деревоперерабатывающей промышленности с длительным периодом разложения. Увеличение объёма потребления синтетических полимерных материалов ведет к накоплению неразлагающихся биологическими объектами отходов не свойственных природным экосистемам, складированию их на полигонах, к отчуждению земель агропромышленного комплекса, деградации почв, ландшафтов. Токсичные бытовые и технологические отходы с длительным периодом распада на полигонах литосферы под действием тепловой, световой энергий и атмосферных осадков подвергаются деструкции, образуя токсичные летучие вещества, которые в атмосферном воздухе формируют фотохимический смог или кислотные дожди, 


\section{СТАБИЛИЗАЦИЯ СВОЙСТВ ТОПЛИВНО-ЭНЕРГЕТИЧЕСКИХ СИСТЕМ НА ОСНОВЕ ПРИРОДНЫХ И СИНТЕТИЧЕСКИХ ПОЛИМЕРОВ}

вызывая изменение $\mathrm{pH}$ среды обитания, угнетение или гибель живых организмов [2, с. 70$]$.

Наибольшую опасность для атмосферы представляют стационарные источники загрязнения - тепловые электростанции (ТЭЦ, ТЭС) и передвижные - автомобильный, железнодорожный, авиационный транспорт, которые выбрасывают газообразные вещества, такие как, диоксид азота $\left(\mathrm{NO}_{2}\right)$, диоксид серы $\left(\mathrm{SO}_{2}\right)$, оксиды углерода $\left(\mathrm{CO}_{2}, \mathrm{CO}\right)$, углеводороды $\left(\mathrm{C}_{\mathrm{n}} \mathrm{H}_{\mathrm{m}}\right)$. Чрезмерный вынос биогенных элементов при выращивании пищевого сырья в агропромышленном комплексе привел к снижению гумуса и продуктивности фитоценозов, обеспечивающих человека продовольствием, топливом, строительными материалами, сырьем для многих видов промышленности. Негативное антропогенное воздействие, изменяя состав и структуру почв селитебных и санитарно-защитных 30н, формирует опасности для последующих фитоценозов и биометрические свойств почвы. Аккумулирование или депонирование токсичных веществ в поверхностном слое почвы изменяют ее структуру, физико-химические свойства (плотность, гидрологический режим), содержание гумуса, которое возобновляется в течение $10 \ldots 100$ тыс. лет.

Безопасное функционирование природных экосистем на современном этапе во многом зависит от управления качеством техногенных систем, разработки эффективных инструментариев решения глобальных проблем и производства возобновляемых энергетических ресурсов.

В связи с истощением мировых запасов нефти и природного газа техногенные углеродсодержащие отходы жизнедеятельности можно рассматривать как потенциальные возобновляемые энергетические ресурсы. Низкая степень использования отходов в России связана с их неоднородным химическим составом, нестабильными физико-химическими свойствами и энергетическими затратами на деструкцию полимерных связей. 


\section{СТАБИЛИЗАЦИЯ СВОЙСТВ ТОПЛИВНО-ЭНЕРГЕТИЧЕСКИХ СИСТЕМ НА ОСНОВЕ ПРИРОДНЫХ И СИНТЕТИЧЕСКИХ ПОЛИМЕРОВ}

Для получения дешевого и экологически безопасного возобновляемого энергетического сырья, повышения эффективности производства и рационального управления технологическими процессами разработана эффективная методология стабилизации свойств энергетических систем на принципах интегральной оценки качества техногенных почв, поверхностных вод при замене природного сырья (биополимеров) на синтетические аналоги. Разработанная методология позволяет минимизировать количество летучих компонентов в составе промышленных материалах, значительно сократить тепловые и газообразные выбросы в атмосферный воздух при утилизации синтетических и природных полимерных целлюлозосодержащих отходов при получении биогаза и гумифицированной почвы. Замена природного сырья (биополимеров) на синтетические аналоги позволит замедлить скорость потребления возобновляемых природных ресурсов и восстановить энергетический баланс природных экосистем. 


\section{ГЛАВА 1.}

\section{ИНСТРУМЕНТАРИИ СТАБИЛИЗАЦИИ КАЧЕСТВА ПРИРОДНЫХ И ТЕХНОГЕННЫХ ЭКОСИСТЕМ}

\section{1 Экологические основы безопасного функционирования природных экосистем. Концепция стабильного развития биосферы}

Для получения дешевого и экологически безопасного возобновляемого энергетического сырья, повышения эффективности производства и рационального управления технологическими процессами разработана эффективная методология стабилизации свойств энергетических полимерных систем. На первом этапе исследований проведен теоретический анализ структуры и свойств природных экосистем, причин нарушения их стабильности, современных инструментариев выхода из экологического кризиса. Разработана концепция интегральной оценки качества техногенных почв, поверхностных вод.

Концепция преобладающей роли человека в биосфере привела к увеличению техногенного риска, возникновению глобальных проблем, решение которых затрагивает многие отрасли техносферы и агросферы. Поэтому в основе концепции стабильного развития биосферы лежат принципы экологической безопасности, гармонического управления динамическим равновесием потоков вещества и энергии в природных экосистемах. В основе управления энергетическими потоками биосферы лежит человеческий разум, формирующий мировоззрение о целостности природных экосистем, возобновления природных ресурсов.

В основе структуры и функционирования природных экосистем лежит концепция единства физического и биологического миров (рис.1.1), самопроизвольного распределения вещества между компонентами экосистемы и направленного распределения энергетических потоков. В состав абиотической (А) части экосистемы входят энергия, вода, газовый состав 
атмосферы, почва, почва - грунт. Основные компоненты биотической (Б) части: растения (продуценты), синтезирующие органическое вещество; животные (консументы), потребляющие готовое органическое вещество; микроорганизмы (редуценты), разлагающие органическое вещество до неорганических веществ (минеральные соли, газы, воду). Взаимодействие компонентов абиогенной части экосистемы между собой и с компонентами биогенной части осуществляется в результате круговорота биогенных элементов: азота $(\mathrm{N})$, фосфора (Р), углерода (C), водорода (H), кислорода (O), серы (S), который протекает циклично и неравномерно во времени, поддерживая стабильные условия экосистемы. Сообщества растений - фитоценоз, животных - зооценоз, микроорганизмов - микробиоценоз при совместном взаимодействии друг с другом и экологическими факторами образуют более крупную экосистему биоценоз. Передача информации осуществляется на молекулярном уровне. Отходы вещества, выпадающие из круговорота вещества, накапливаются в абиогенных объектах (почве, поверхностных водах) экосистемы и подвергаются биохимической деструкции до биогенных элементов, которые вновь вовлекаются в круговорот веществ или переходят в связанное состояние и депонируются в виде природных энергетических ресурсов: гумуса, каменного или бурого угля, известняка, торфа, сапропеля, сланцев, нефти [3, с.73].

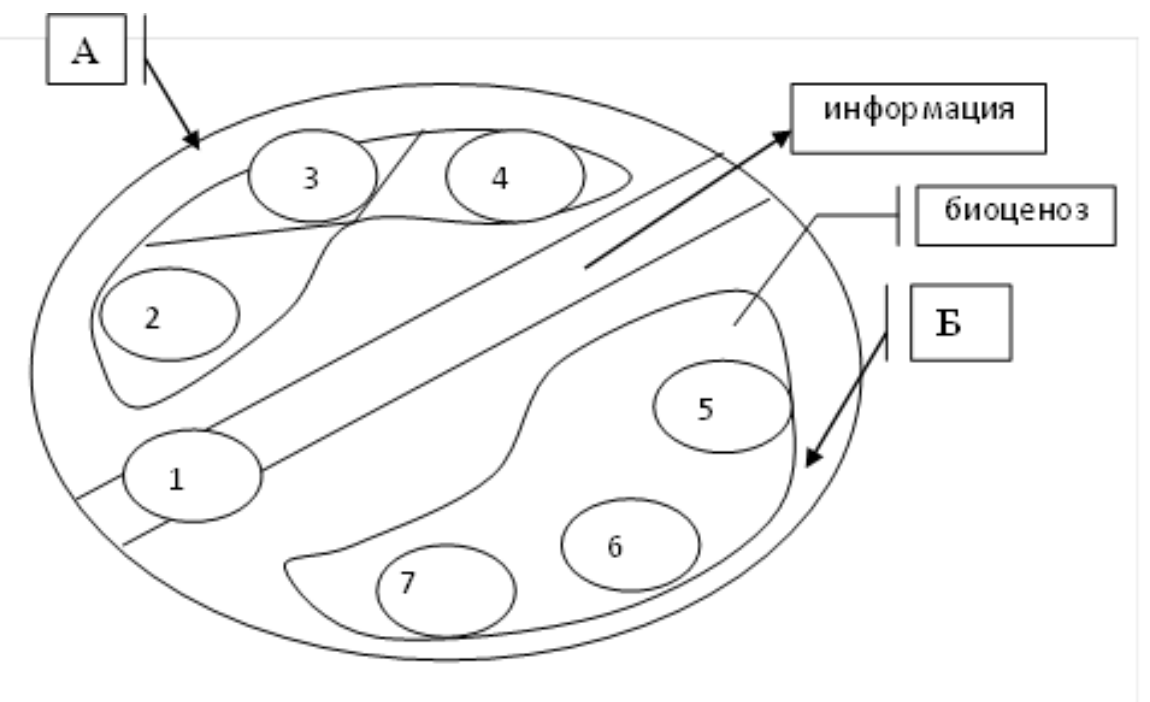

Рис. 1.1. Схема экосистемы: 1 - почва, грунт; 2 - газовый состав; 3 - энергия, 4 - вода; 5 - консументы; 6 - редуценты; 7 - продуценты 


\section{СТАБИЛИЗАЦИЯ СВОЙСТВ ТОПЛИВНО-ЭНЕРГЕТИЧЕСКИХ СИСТЕМ НА ОСНОВЕ ПРИРОДНЫХ И СИНТЕТИЧЕСКИХ ПОЛИМЕРОВ}

При изменении какого-либо экологического фактора от оптимальных значений равновесие в экосистеме нарушается и восстанавливается при новых условиях в течение длительного промежутка времени и зависит от адаптации живых организмов. В зависимости от того, насколько быстро экосистема возвращается в состояние равновесия при новых условиях, будет зависеть ее стабильность.

Глобальная экосистема - биосфера включает атмосферу, гидросферу верхнюю часть литосферы (3 км), между которыми происходит обмен биогенными элементами. В результате круговорота веществ подвижные формы биогенных элементов поступают из почвы, воды и атмосферного воздуха в живые организмы и переходят в связанное полимерное состояние. Часть живого вещества выпадает из биосферы в виде детрита - мертвого вещества, подвергаясь деструкции, возвращается в круговорот вещества или остается в виде отходов - органогенные природные ресурсы. Наиболее замедленная часть круговорота веществ связана с процессами миграции и циркуляции. Так, например, подземные воды обновляются за 5 тыс. лет, воды океана за 3 тыс. лет, атмосферные воды за 10 суток. В результате круговорота веществ происходят также процессы самоочищения атмосферы, гидросферы, литосферы. Человеческое общество, используя живое вещество и энергию преобразовала часть биосферы в техносферу, агросферу и мегаполисы и нарушила гомеостаз природных экосистем, механизмы саморегулирования и самовосстановления живого вещества. Рост населения и увеличение границ техносферы привело к экологическому кризису и необходимости разработки современных инструментариев решения глобальных проблем. Антропогенная деятельность, направленная на улучшение условий жизни людей, привела к увеличению экологического риска от реальных и потенциальных опасностей. Возросла частота природных катастроф и техногенных аварий. Глобальные проблемы связаны с интересами всего человечества (ноосферы) и взаимосвязаны друг с другом (рис. 1.2) [4, с.166]. Нельзя решать 
продовольственную проблему, не затрагивая энергетику, использующую природные ресурсы. Чрезмерное использование природных ресурсов приводит к исчезновению мест обитаний живых организмов, что в свою очередь приводит к их гибели, снижению индекса разнообразия, нарушению гомеостаза природных экосистем.

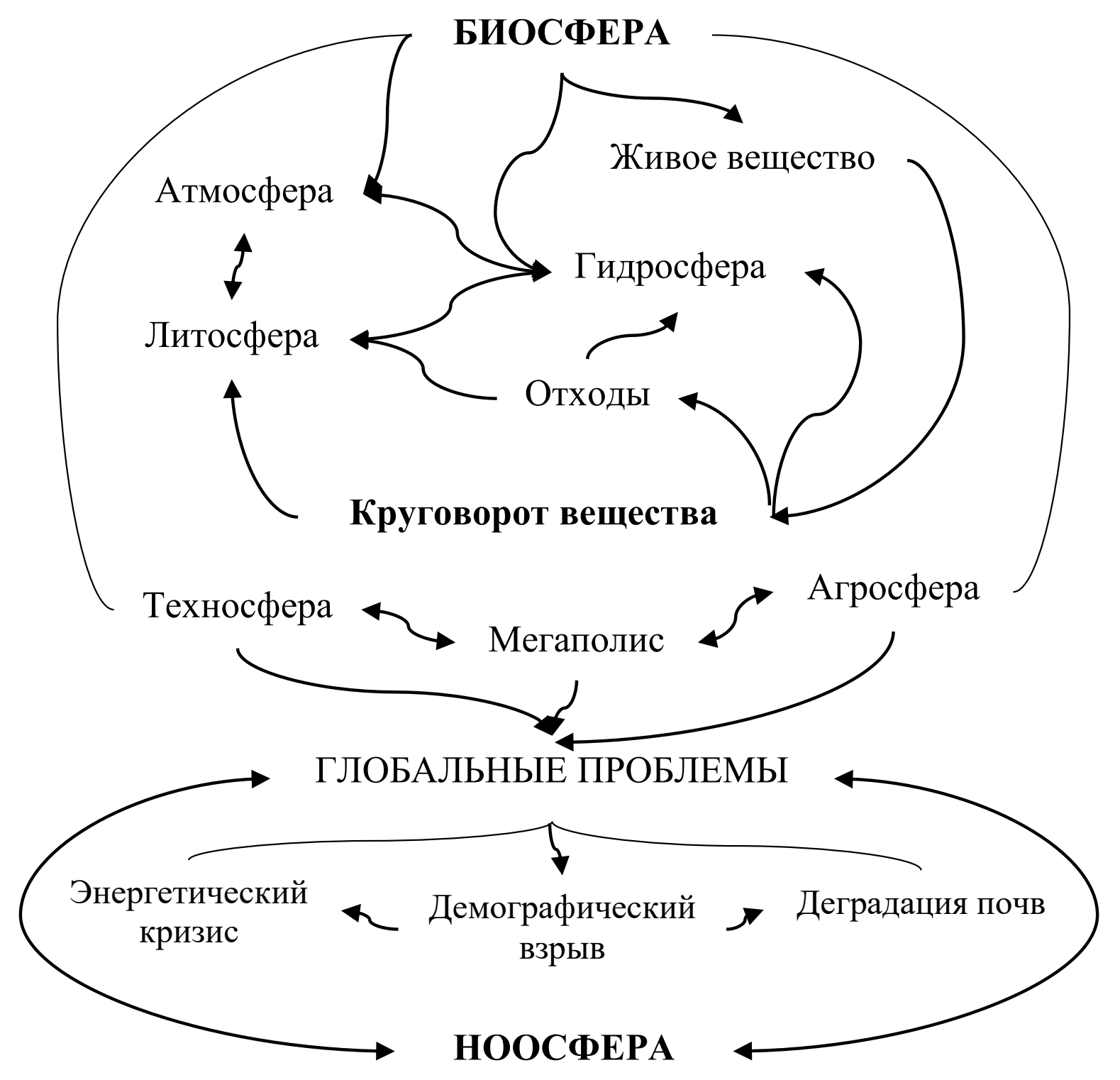

Рис. 1.2. Модель возникновения глобальных проблем

Выход из экологического кризиса невозможен без формирования ноосферы и разумного решения глобальных проблем. Поэтому первостепенную роль в управлении стабильности качества природных и техногенных систем и 
минимизации техногенного риска отводят мониторингу природных и техногенных экосистем для выявления приоритетных факторов риска и разработки методологии стабилизации качества техногенных экосистем.

\section{2 Методология мониторинга техногенных экосистем}

В основе методологии количественной оценки факторов риска лежат регулярные наблюдения в пространстве и времени по приоритетным загрязнителям и факторам, связанных с загрязнениями. Единая государственная система экологического мониторинга (ЕГСЭМ) предусматривает создание двух взаимосвязанных блоков: мониторинг загрязнения экосистем и мониторинг экологических последствий такого загрязнения [5, с. 180]. Принципы классификации мониторинга представлены на рисунке 1.3. Основной целью глобального мониторинга является сбор информации путем регулярных наблюдений в пространстве и времени по приоритетным стандартным показателям качества и безопасности. Мониторинг загрязнения природных экосистем проводят с учетом фоновых загрязнений, так как естественные природные загрязнители ассимилируются биосферой в процессе эволюции и образуют естественный фон загрязнений. Данные мониторинга «прошлого» биосферы необходимы для анализа динамики биосферы (по материалам палеозоологии и палеоботаники, отложениям озер, коралловым рифам, ледникам, годичным кольцам деревьев и т. д.), временем заметного воздействия на биосферу, началом глобального загрязнения.

Наблюдением за скоростью поступления, миграцией, трансформацией чрезвычайно опасных химических веществ в биосфере и накоплением их в производственном цикле источников загрязнения занимается химический мониторинг. При возникновении техногенных аварий и ликвидации их последствий возникают чрезвычайно опасные зоны, в которых наблюдение за распространением опасных веществ проводится в рамках импактного 
мониторинга. Физический мониторинг - наблюдения за изменениями геофизического состояния биосферы, которые приводят к изменению климата, природным катастрофам. Биологический мониторинг наблюдает за изменением биологической продуктивности биоценозов. Недостатком этих методов является малая вероятность прогноза взаимодействий опасных загрязнителей с компонентами экосистемы и образование со временем устойчивых связей в биомассе живого вещества, снижающих степень их миграции в трофических цепях и депонирования в почве.

\section{МОНИТОРИНГ}

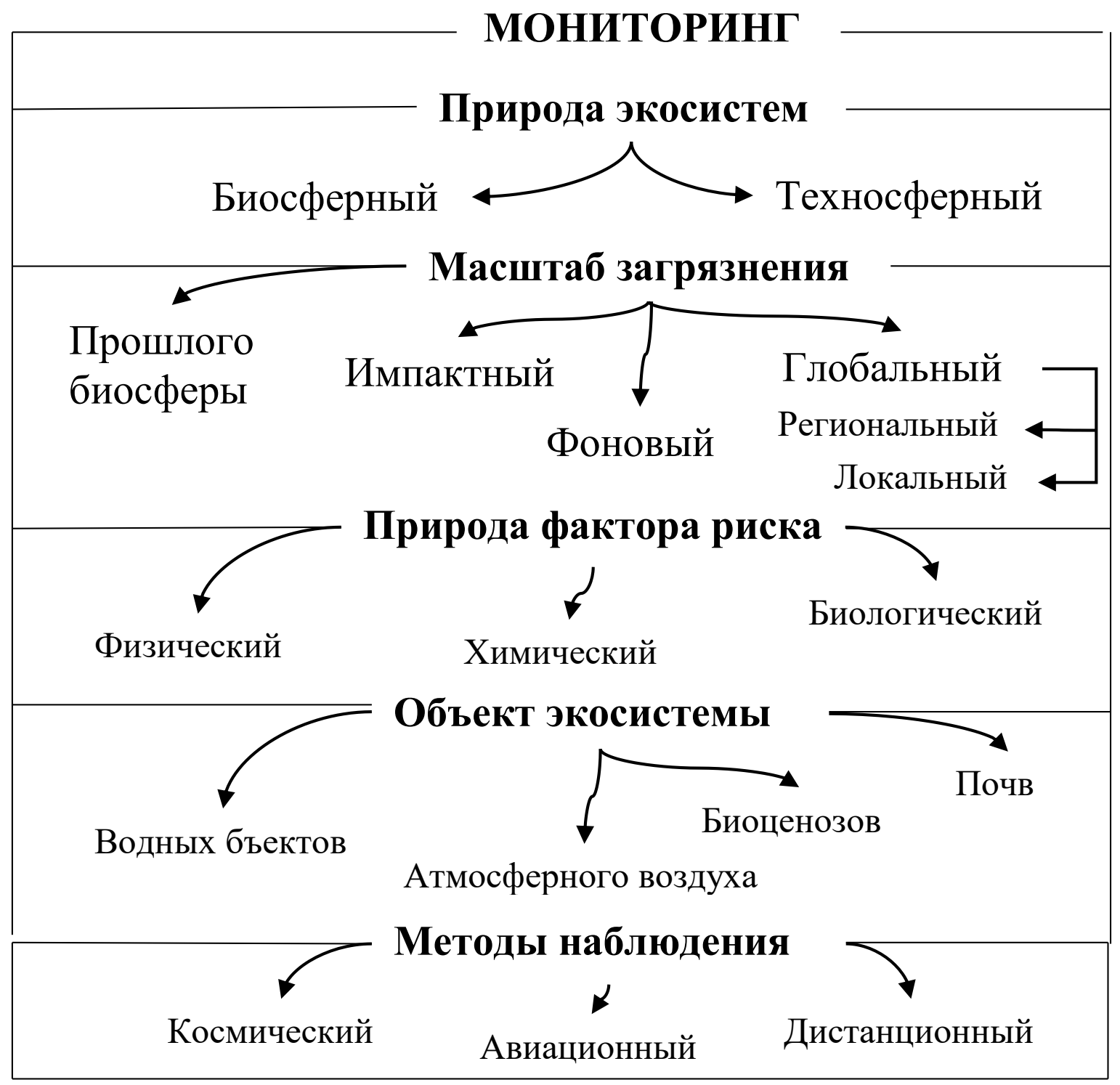

Рис. 1.3. Схема классификации мониторинга 


\section{СТАБИЛИЗАЦИЯ СВОЙСТВ ТОПЛИВНО-ЭНЕРГЕТИЧЕСКИХ СИСТЕМ НА ОСНОВЕ ПРИРОДНЫХ И СИНТЕТИЧЕСКИХ ПОЛИМЕРОВ}

Стабильность природных и техногенных экосистем определяется продуктивностью почв и фитоценозов. Поэтому приоритетом мониторинга техногенных экосистем должен стать почвенно-биотический комплекс, в котором центральное звено занимают почвы (рис. 1.4). Мониторинг почв позволит проследить миграционный путь опасного вещества в почвеннобиотической системе и оценить стабильность качества и минимизировать техногенный риск. Миграционный путь опасного вещества в системе связан с биохимической деструкцией в пищевых цепях почвы и сопредельных компонентах системы: воздухе, воде, растениях, животных, микроорганизмах, пищевом сырье или локализацией подвижных форм токсичных веществ в почвенных коллоидах с последующим переводом в недоступную форму для биотического круговорота.

\section{ФАКТОР РИСКА}
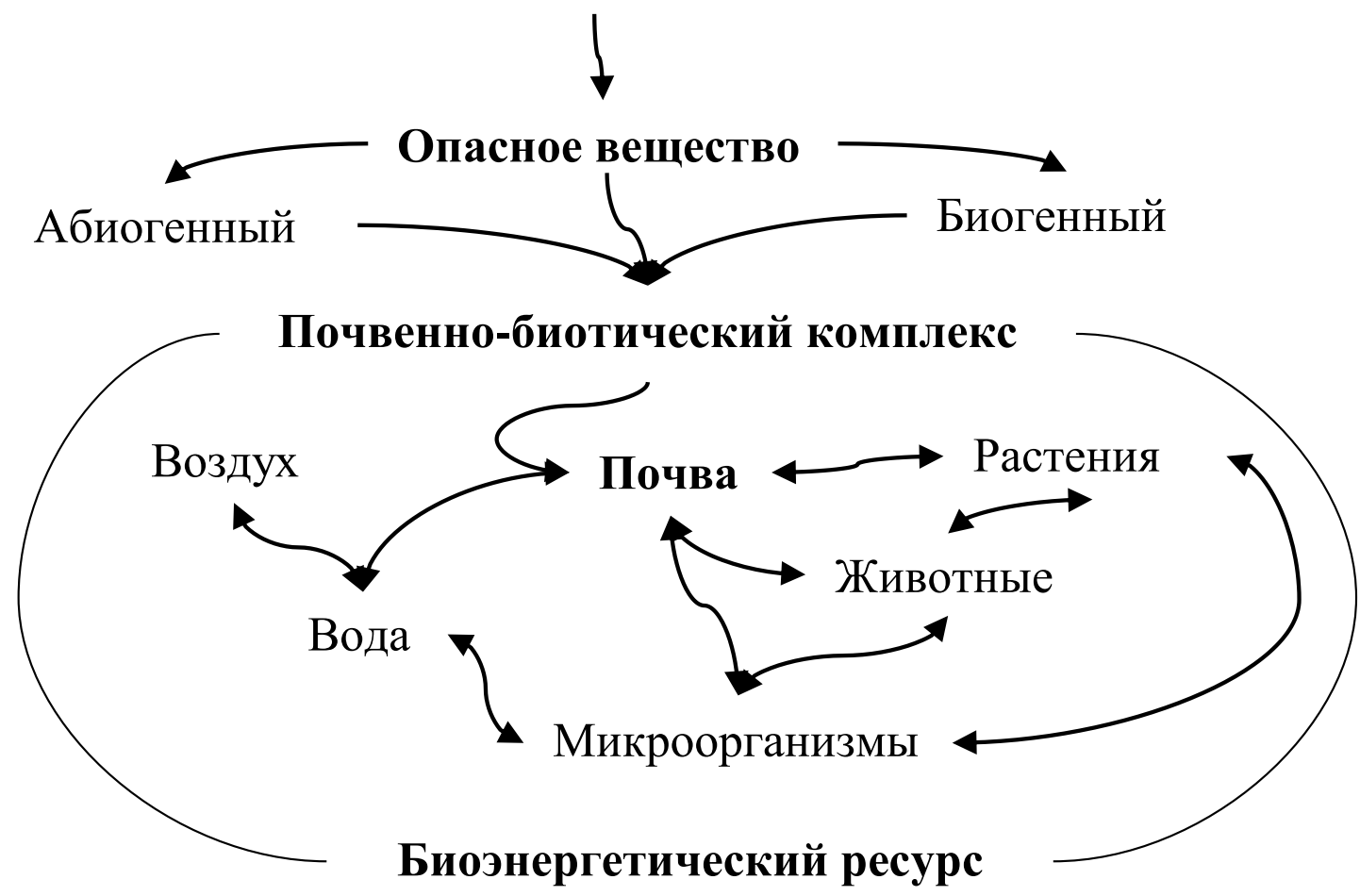

Рис. 1.4. Модель миграции факторов риска

в почвенно-биотическом комплексе 


\section{СТАБИЛИЗАЦИЯ СВОЙСТВ ТОПЛИВНО-ЭНЕРГЕТИЧЕСКИХ СИСТЕМ НА ОСНОВЕ ПРИРОДНЫХ И СИНТЕТИЧЕСКИХ ПОЛИМЕРОВ}

При длительном воздействии факторов риска на растения тормозится экспрессия генов, усиливаются гидролитические процессы, нарушается биосинтез фитогормонов, синтезируются стрессовые белки [6, с. 16]. Снижение защитных функций растений по изменению биометрических показателей (цвета листовой пластинки, раннее усыхание или опадание листьев, хлороза и некроза листьев, свертывание листьев) чрезвычайно трудно, поскольку при длительном воздействии токсичных веществ на живые организмы суммируются все без исключения биологически важные изменения [7, с. 108]. Поэтому качество фитоценоза часто оценивают по динамике ферментативной активности почвы, катализирующей окислительные или восстановительные реакции деструкции биогенных отходов и трансформацию в почве соединений азота и фосфора, углеводов. Снижения защитных функций растений проявляется на расстоянии $5 . .10$ км от источника выброса.

\subsection{1 Инструментарии химического мониторинга техногенных систем}

Экологическая безопасность функционирования производственнопромышленных техногенных систем основана на концепции минимизации техногенного риска и использовании традиционных инструментариев химического мониторинга, регламентированных требованиями ГОСТ или СанПиН. Современные инструментарии качества, достоверно оценивая наблюдение за источниками загрязнения техногенных экосистем, базируются на термодинамических и кинетических законах превращения вещества и энергии (рис. 1.5). В настоящее время установлена тесная взаимосвязь между термодинамическими функциями, физико-химическими, физикомеханическими и структурными особенностями различных тел. 


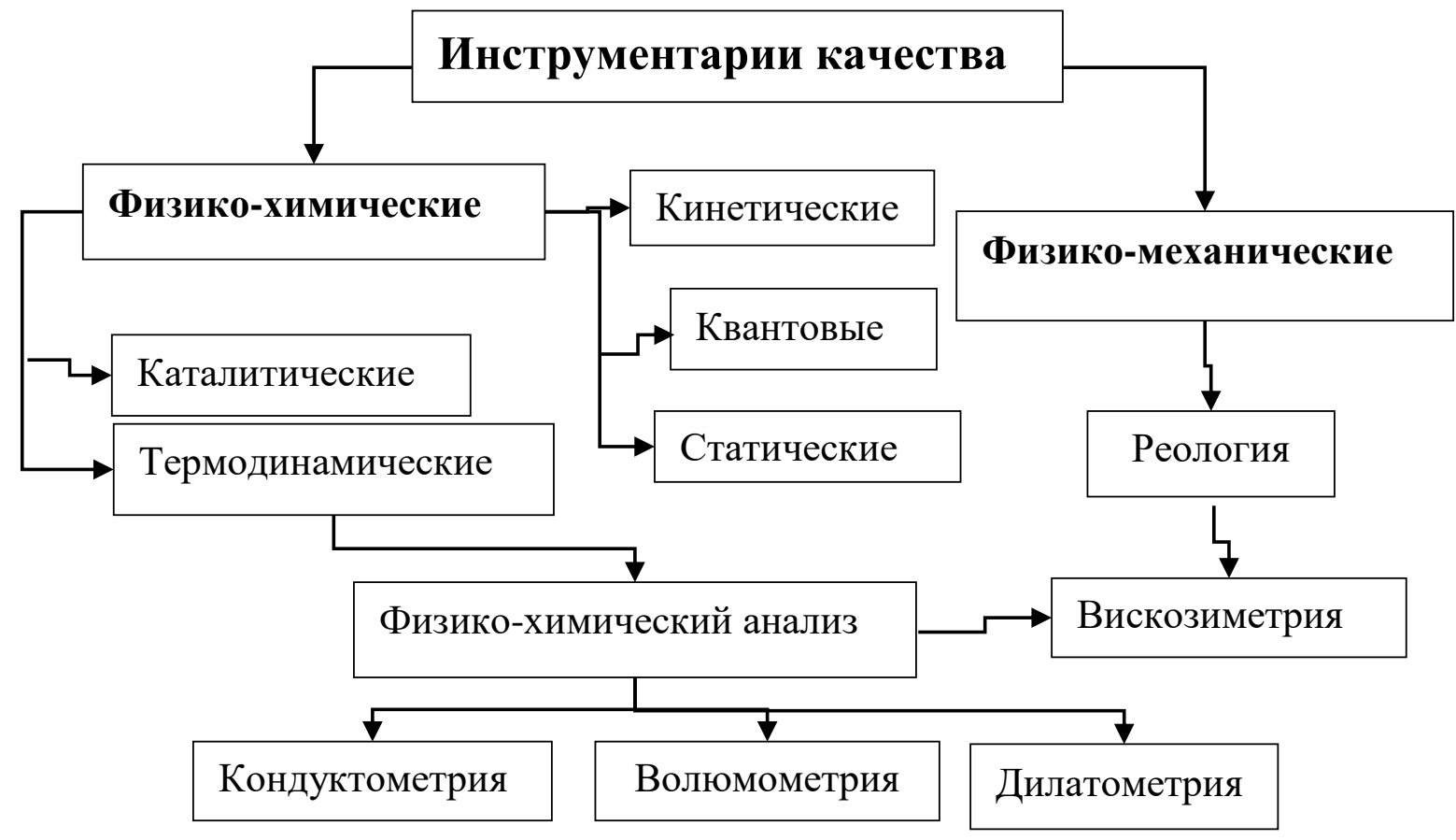

Рис. 1.5. Схема инструментариев качества

C помощью математических законов устанавливается соотношение между энергией и термодинамическими равновесными свойствами системы (давление, объем, температура, концентрация), не учитывая строение молекул и механизм взаимодействия. Если изменяется какое-либо из термодинамических свойств, то одновременно будут изменяться и другие свойства системы. Изменение термодинамических функций объясняют возможности и направление протекания химической реакции, межмолекулярные взаимодействия в жидкофазных системах, устанавливают закономерности изменения структурно-термодинамических характеристик во всем диапазоне составов, моделируют химические реакции в агрессивных средах [5, с.8- 63] и оптимизируют параметры технологических процессов [9, с.9].

Методы квантовой механики опираются на законы волновой механики движения электронов, ионов, атомов, молекул. Устойчивое динамическое состояние системы микрочастиц по теории вероятности описывается состоянием электронов совокупностью квантовых чисел с использованием уравнения Шредингера. 


\section{СТАБИЛИЗАЦИЯ СВОЙСТВ ТОПЛИВНО-ЭНЕРГЕТИЧЕСКИХ СИСТЕМ НА ОСНОВЕ ПРИРОДНЫХ И СИНТЕТИЧЕСКИХ ПОЛИМЕРОВ}

Особенности движения микрочастиц и их активацию во времени исследуют кинетическими методами. Физико-химический анализ позволяет судить о взаимодействии веществ по зависимости свойств равновесных систем (температуры, электропроводности, коэффициента термического расширения, твердости, плотности, вязкости, поверхностного натяжения, показателя преломления и другие) от состава. Методы физико-химического анализа: термический, микроструктурный, рентгенографический, кондуктометрия, дилатометрия, вискозиметрия основаны на принципах непрерывности и соответствия Н.С. Курнакова [10, с. 9].

Молекулярная спектроскопия, радиоспектроскопия, ЯМР, электронное сканирование позволяют объяснить строение молекул за счет изменения внутримолекулярных сил, связывающих атомы в молекулу, рассчитать термодинамические свойства, моделировать механизм химических реакций. Результатом подобных исследований является графическое построение фазовых диаграмм состав - свойство. Геометрический анализ диаграмм состояния позволяет установить характер взаимодействия между компонентами, области существования и составы равновесных фаз.

Термодинамический метод используется при моделировании процесса горения топлива в тепловых двигателях (ДВС). Горение топлива в ДВС представлен как многостадийный динамический равновесный процесс последовательных, обратимых и параллельных химических реакций, протекающих при температуре $500 \ldots 700 K$ и выше с образованием многокомпонентной смеси газообразных веществ $\left(\mathrm{N}_{2}, \mathrm{~N}_{2} \mathrm{O}, \mathrm{NO}_{2}, \mathrm{NO}, \mathrm{NH}, \mathrm{N}\right.$, $\mathrm{C}_{\mathrm{n}} \mathrm{H}_{\mathrm{m}}$ и других соединений). Определена лимитирующая стадия горения деструкции азотсодержащих веществ. Разработан алгоритм расчета концентраций оксидов азота в отработавших газах и обоснован способ снижения концентрации оксидов азота, предложена методология минимизации токсичных веществ в отработавших газах ДВС [11, с.38.]. На основании 


\section{СТАБИЛИЗАЦИЯ СВОЙСТВ ТОПЛИВНО-ЭНЕРГЕТИЧЕСКИХ СИСТЕМ НА ОСНОВЕ ПРИРОДНЫХ И СИНТЕТИЧЕСКИХ ПОЛИМЕРОВ}

многолетних исследований выброса токсичных веществ в атмосферный воздух передвижными и стационарными источниками загрязнений, загрязнения дерново-подзолистых почв, предложена методология оценки техногенного риска [4, с.167], основанная на концепции максимально приемлемого риска и принципах безопасного и стабильного функционирования техногенных экосистем (рис. 1.6).

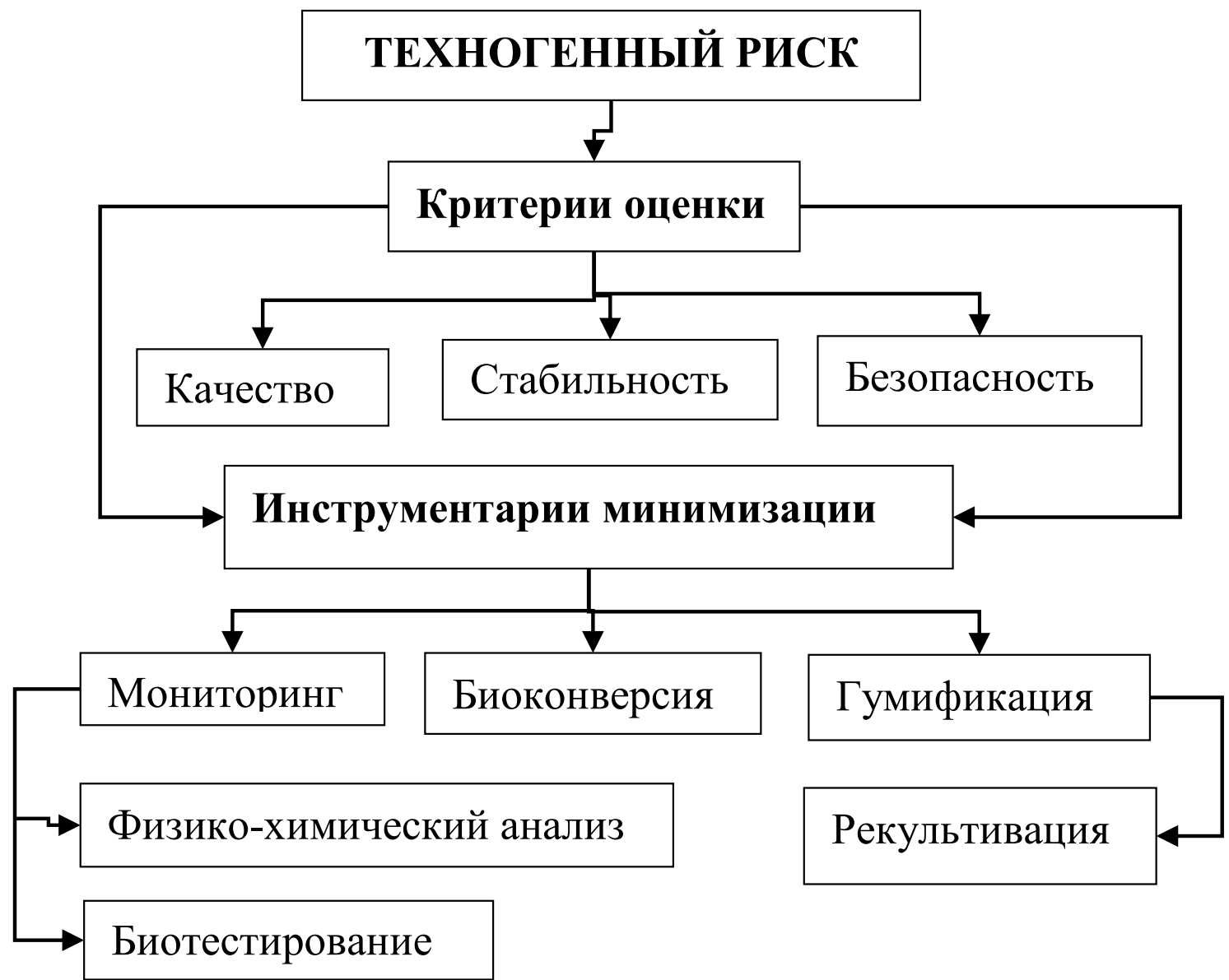

Рис. 1.6. Методология минимизации техногенного риска

Оценку стабильности качества техногенных объектов проводился с использованием инструментариев химического и биологического мониторинга. Управление минимизацией техногенного риска осуществлялся с помощью инструментариев физико-химического анализа, путем гумификации целлюлозосодержащих отходов анаэробной биоконверсией с последующей 


\section{СТАБИЛИЗАЦИЯ СВОЙСТВ ТОПЛИВНО-ЭНЕРГЕТИЧЕСКИХ СИСТЕМ НА ОСНОВЕ ПРИРОДНЫХ И СИНТЕТИЧЕСКИХ ПОЛИМЕРОВ}

рекультивацией техногенных почв. Экологически-безопасное

функционирование производственно-промышленных объектов техногенных систем гарантирует технологические показатели качества и защиту от фальсифицированной продукции на глобальном рынке. Особенности производственного мониторинга заключаются в наблюдении за динамикой распространения загрязняющих веществ на всех стадиях жизненного цикла продукции: сырье $\rightarrow$ технологические массы $\rightarrow$ конечный продукт инструментариями химического мониторинга (рис. 1.7).

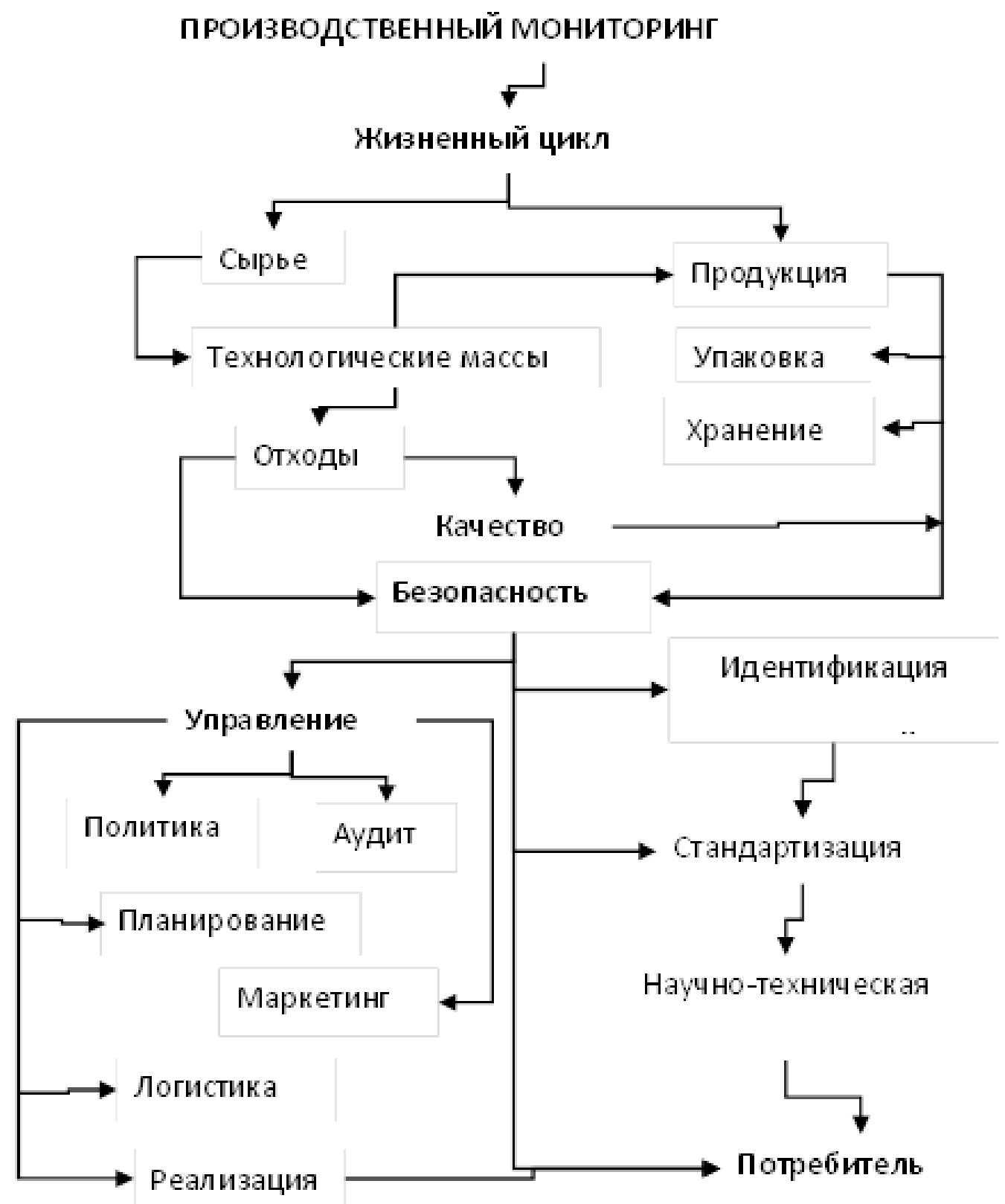

Рис. 1.7. Производственный мониторинг продукции 


\section{СТАБИЛИЗАЦИЯ СВОЙСТВ ТОПЛИВНО-ЭНЕРГЕТИЧЕСКИХ СИСТЕМ НА ОСНОВЕ ПРИРОДНЫХ И СИНТЕТИЧЕСКИХ ПОЛИМЕРОВ}

Управление качеством и безопасностью изготавливаемой продукции начинается с момента разработки технологической схемы, проведения лабораторных, опытно-промышленных испытаний до реализации готового изделия потребителю. Мониторинг начинается с идентификации опасностей сырья, технологических масс, конечного продукта, отходов в течение квартала, года.

Контроль качества на производстве осуществляется системой менеджмента качества, политикой, планированием, маркетингом, логистикой с учетом ориентации на потребителя, аудитом, экономии ресурсов, стандартизации, техническому регулированию при разработке технической документации, гарантирующей предприятию стабильные технологические показатели качества.

\subsection{2 Производственный мониторинг лекарственных препаратов}

Производственный мониторинг проводился на примере производства лекарственных препаратов группы антибиотиков для лечения заболеваний, вызванных бактериальными инфекциями и пирацетама для лечения сосудов головного мозга. Использование лекарственных препаратов, изготовленных с нарушением правил хранения, упаковки, очистки субстанций на стадии жизненного цикла приводят к экстренной госпитализации пациентов или летальным исходам. Уровень фальсифицированных антибиотиков, препаратов для лечения сердечно сосудистых заболеваний доходит до $30 . .50 \%$ [12, с. 15].

Биологическая активность лекарственных препаратов определяется химическим строением молекул действующего вещества и расположением свободных функциональных групп. Лечебное действие антибиотиков, вырабатываемых микроорганизмами, основано на ингибировании роста патогенных микроорганизмов и их гибели. Избирательное действие антибиотиков связано не только с влиянием на микробную клетку, но и с 
химической структурой, со степенью токсичности. Опасность антибиотиков зависит от индивидуального восприятия больного, частого применения, что приводит к обострению болезни, возникновению хронических заболеваний и осложнениям [13, с. 23]. Наибольшее распространение в лечебной практике получили эффективные антибиотики группы цефалоспоринов третьего поколения, преимущество которых заключается в высокой антибактериальной активности, низкой токсичности, высокой активности к широкому спектру бактерий, не поддающихся лечению другими антибиотиками (пенициллинами).

Идентификацию опасных факторов - содержание летучих низкомолекулярных веществ при производстве антибиотиков группы цефалоспоринов цефтриаксона осуществлялась с помощью стандартных методов Фармакопейных Статьей Предприятия (ФСП) [14]. Фармакодинамические и фармакокинетические характеристики цефтриаксона определяются химическим составом $\left(\mathrm{C}_{18} \mathrm{H}_{18} \mathrm{O}_{7} \mathrm{~N}_{8} \mathrm{~S}_{3}\right)$ действующего вещества (рис. 1.8).<smiles>CO/N=C(\C(=O)NC1C(=O)N2C(C(=O)O)=C(CSc3nc(=O)c(=O)[nH]n3C)CS[C@H]12)c1csc(N)n1</smiles>

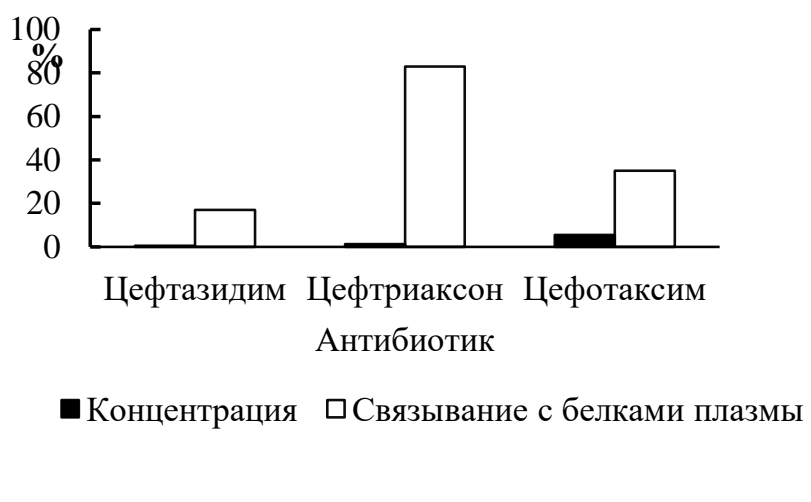

Рис. 1.8. Характеристика антибиотиков группы цефаллоспоринов:

а) структурная формула цефтриаксон; б) концентрация действующего вещества и связывание с белками плазмы

Характерным элементом химической структуры цефалоспоринов являются бета-лактамное и дигидротиазиновое кольцо 7 -аминоцефалоспорановой кислоты $[15$, с.50]. Характер радикала бета- 
лактамного кольца определяет степень связывания антибиотика белками, а дигидротиазинового кольца - стабильность. Расщепление $\beta$-лактамной связи приводит к исчезновению свойств антибиотика и появлению аллергического действия. Период полувыведения большинства цефалоспоринов из организма колеблется в пределах 1-2 часа. Более длительный период полувыведения имеет цефтриаксон $(\approx 8,5$ ч), что обеспечивает возможность их назначения один раз в сутки. Наибольшее взаимодействие с белками крови наблюдается $\mathrm{y}$ цефтриаксона, что позволяет снизить суточную дозу при лечении (рис. 1.8 б).

Наблюдение за динамикой показателей качества цефтриаксона проводилось по содержанию остаточных количеств токсичных низкомолекулярных летучих компонентов в сырье и конечном продукте: ацетона, метанола, хлорида метилена и триэтиламина (рис. 1.9). Количество этих примесей в составе готового продукта зависит от способа синтеза, очистки, типа лекарственной формы. Чаще всего очистку цефтриаксона осуществляют экстракцией водно-органическими растворителями (ацетон, хлорид метилена, метанол) в присутствии аминов (триэтиламином) [16, с.136]. Содержание остаточных количеств метанола (ацетона или триэтиамина) в субстанциях, отобранных в течение $1 . .4$ квартала не изменяется и в 100 раз меньше предельно допустимой концентрации (ПДК). Аналогичная зависимость обнаружена и в готовой форме цефтриаксона. Хлорид метилена не обнаружен во всех отобранных пробах за период $1 . .4$ квартал.
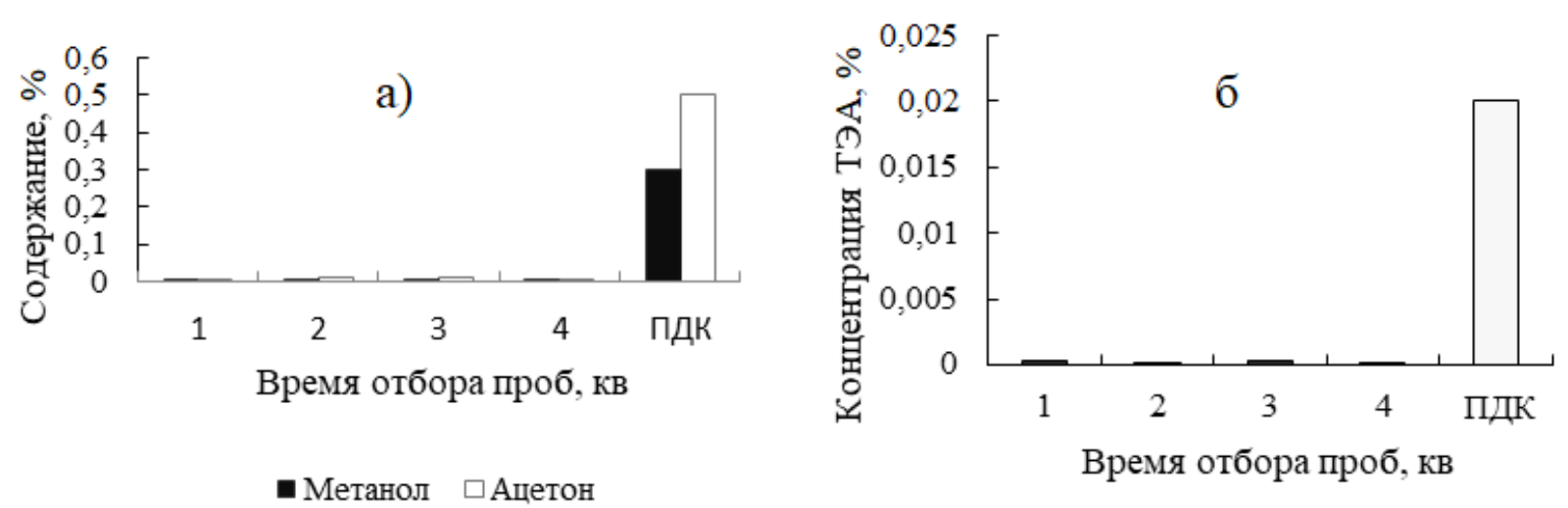

Рис. 1.9. Изменение содержания остаточных количеств низкомолекулярных веществ в цефтриаксоне от времени отбора проб: а) метанола и ацетона; б) триэтиамиа (ТЭА) 


\section{СТАБИЛИЗАЦИЯ СВОЙСТВ ТОПЛИВНО-ЭНЕРГЕТИЧЕСКИХ СИСТЕМ НА ОСНОВЕ ПРИРОДНЫХ И СИНТЕТИЧЕСКИХ ПОЛИМЕРОВ}

Мониторинг показателей качества антибиотика «цефтриаксона» по содержанию остаточных количеств токсичных низкомолекулярных летучих компонентов в сырье и конечном продукте: ацетона, метанола, хлорида метилена и триэтиламина свидетельствует о соответствии данного лекарственного средства нормативным показателям ФСП, гарантирует его стабильность и безопасность [16, с.136].

Основными этапами производственного мониторинга лекарственного препарата «пирацетама» в форме водного раствора 200 мг/мл для внутреннего и внутримышечного введения являются: приготовление раствора на стадии входного контроля (сухой порошок); стадии приготовления водного раствора концентрации 200 мг/мл; стадии запайки раствора в ампулы по стандартным показателям качества ФСП 42-0490-5125-04 - температуре плавления, влажность сухого порошка, $\mathrm{pH}$ водного раствора.

На стадии входного контроля, отобранные из реактора в течение I...IV кварталов пробы анализировались по показателям качества, идентифицирующих действующее вещество: содержание действующего вещества в 1 мл субстанции, температуре плавления (рис. 1.10a, б), pH, влажности (рис. 1.11а, б).

a)<smiles>NC(=O)CN1CCCC1=O</smiles>

б)

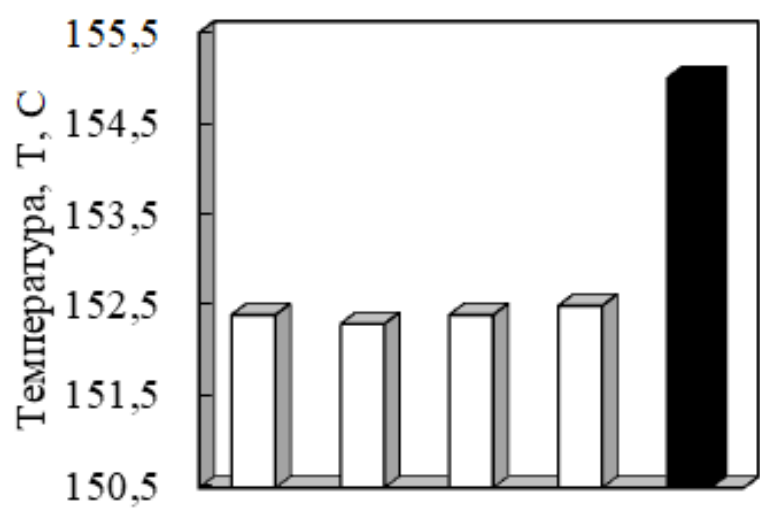

Время отбора пробы, кв

Рис. 1.10. Характеристика действующего вещества «Пирацетам» - 2-оксо-1-пирролидинил-ацетамид: а) структурная формула; б) температура плавления на входном контроле 
Температура плавления сухой субстанции «Пирацетам» соответствует нижней границе нормативного показателя качества фармакопейной статьи $151^{\circ} \mathrm{C}$ (рис. 1.10б). На протяжении всего периода наблюдения (рис. 1.11б) влажность сухого порошка соответствовал $0,2 \%$, а $\mathrm{pH}$ контролируемых проб составила 5,6 (рис. 1.11a). Контроль качества на этой стадии приготовления водного раствора 200 мг/мл осуществляли по изменению концентрации действующего вещества в 1 мл (рис. 1.12а); рН раствора (рис. 1.12б). Количество пирацетама в 1 мл раствора за период I...IV квартал изменяется в пределах 0,193... 0,2 г/мл (рис. 1.12a), а значения $\mathrm{pH}$ колеблются от 5,5 до 5,6 (рис. 1.12б), что свидетельствует о соответствии водного раствора пирацетама нормативным значениям ФСП и гарантирует безопасность препарата для инъекций (200 мг/мл).

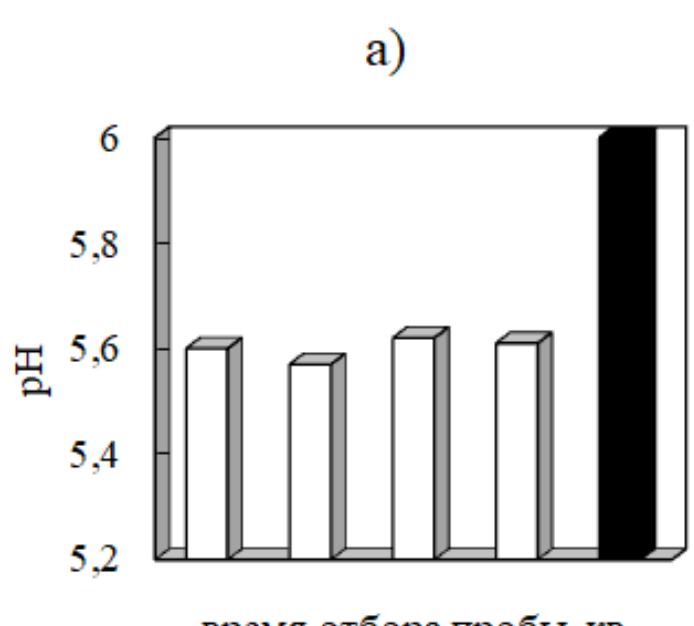

время отбора пробы, кв.

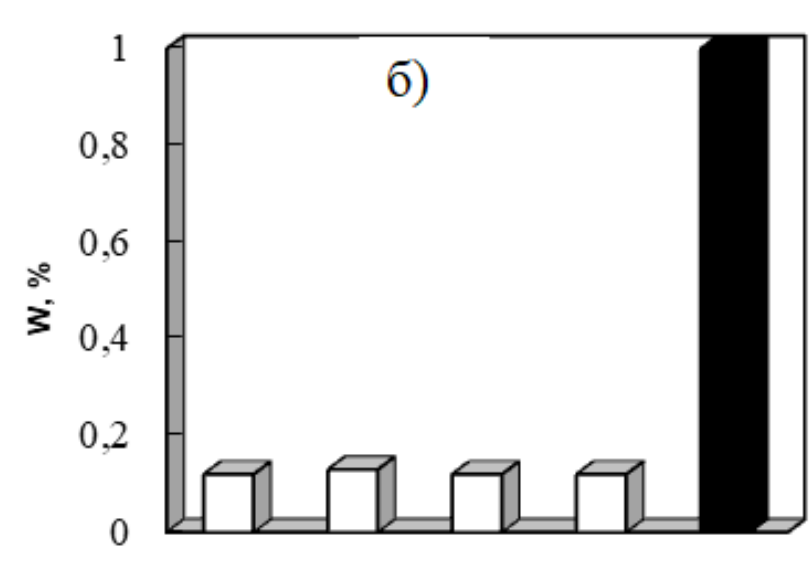

Время отбора пробы, кв.

Рис. 1.11. Изменение показателей качества пирацетама от времени отбора проб на входном контроле: а) рН водного раствора; б) влажность 


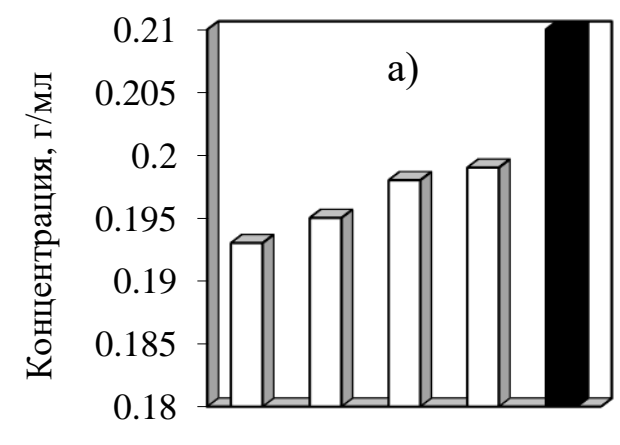

Время отбора пробы, кв.

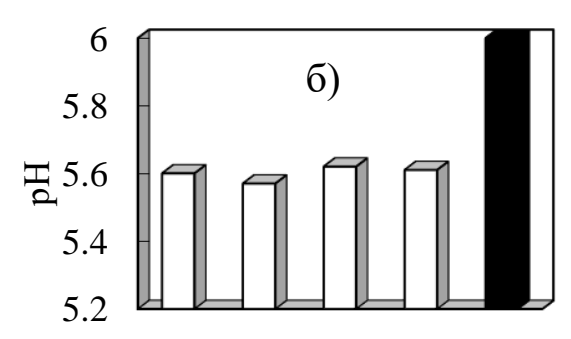

Время отбора пробы, кв.

\section{Рис. 1.12. Изменение показателей качества на стадии приготовления водного раствора пирацетама от времени отбора проб: а) концентрации действующего вещества в 1 мл; б) рН раствора}

Мониторинг лекарственного препарата «Пирацетам» на стадии входного контроля (сухой порошок); стадии приготовления водного раствора концентрации 200 мг/мл; стадии запайки гарантирует стабильные показатели качества и его соответствие фармакопейной статье предприятия (ФСП) 42-0490-5125-04.

Проведенные наблюдения в рамках производственного мониторинга лекарственных препаратов позволили минимизировать риск при изготовлении лекарственных препаратов: антибиотиков группы цефалоспоринов цефтриаксона и ноотропной группы - пирацетама, гарантировать стабильные показатели качества и безопасность готовой продукции, соответствие фармакопейной статье предприятия и удовлетворить требования потребителя.

\subsection{3 Экологический мониторинг поверхностных вод в пределах города Твери}

В единой государственной системе экологического мониторинга получение информации за источниками загрязнений на региональном уровне, установление путей попадания загрязняющих веществ в объекты окружающей 


\section{СТАБИЛИЗАЦИЯ СВОЙСТВ ТОПЛИВНО-ЭНЕРГЕТИЧЕСКИХ СИСТЕМ НА ОСНОВЕ ПРИРОДНЫХ И СИНТЕТИЧЕСКИХ ПОЛИМЕРОВ}

среды, качество атмосферного воздуха, воды и почвы небольших городов и районов, примыкающих к промышленным зонам, определяют по химическим, физическим, гидробиологическим свойствам регламентированных ГОСТ 17.1.3.07-82. Особую опасность для поверхностных вод представляет повышенное содержание растворимых в воде азотосодержащих соединений, которые ускоряют размножение сине-зеленых водорослей, что в свою очередь приводит к исчезновению осетровых рыб, подкислению почв и нарушению ее структуры. В весенне-летний период интенсивного развития водорослей содержание фитопланктона в поверхностных водах может достигать 50 тыс. клеток в 1 мл [17, с. 37]. Мониторинг качества поверхностных вод в пределах города Твери показал, что вода, используемая для питьевого водоснабжения, не отвечает санитарно-гигиеническим нормативам. Концентрация токсичных веществ увеличивается по длине водотока и сохраняется в контрольных створах (10-15 км вниз по течению) реки Волга и в устьях притоков малых рек $[18,19$, c.62].

Исследования качества поверхностной воды малых рек Тьмака (санитарно-защитная зона механического завода и ТЭЦ-1) и устье реки Тверца (Речной вокзал) в пределах города Тверь проводились с использованием инструментариев химического мониторинга. Качество воды не соответствует требованиям СанПиН 2.1.5.5980-00 по таким показателям качества, как содержание общего железа и химического потребления кислорода (ХПК) (рис. 1.13a, б), которые превышают ПДК в два три раза, что согласуется с данными экологического мониторинга, опубликованных в работе [19, с.62]. 

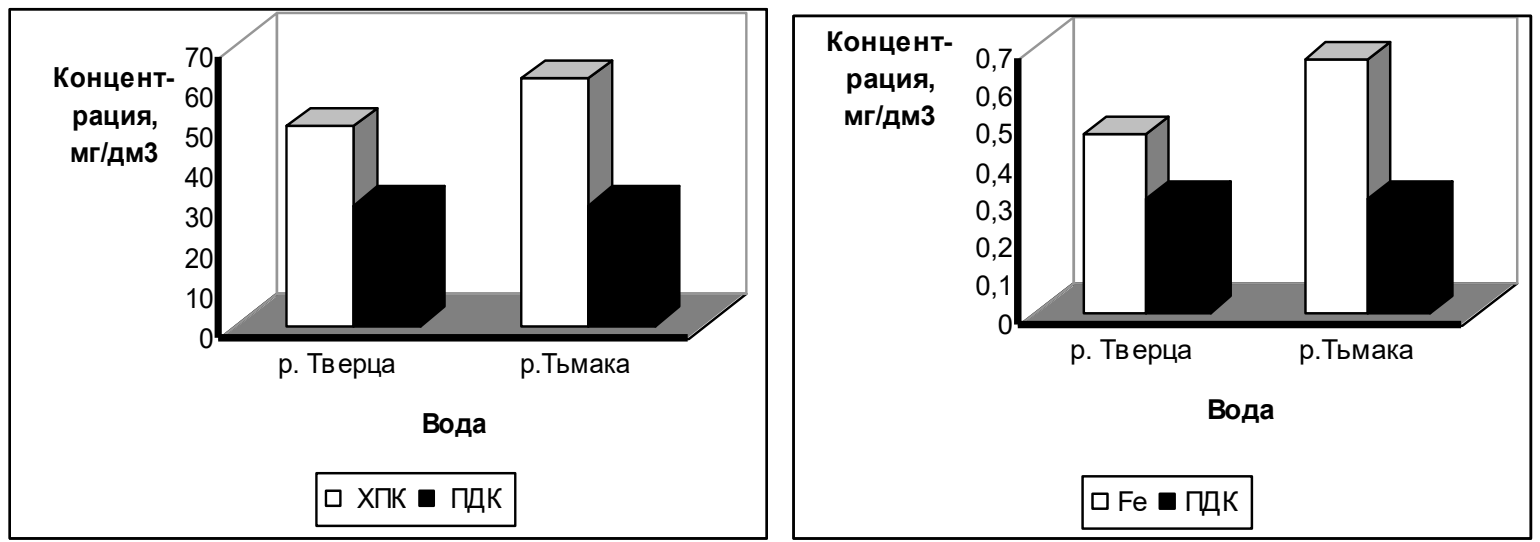

\section{Рис. 1.13. Изменение в реках Тверца и Тьмака: а) химического потребления кислорода (ХПК) и б) общего железа}

Содержание токсичных ионов тяжелых металлов (ТМ) свинца $\left(\mathrm{Pb}^{2+}\right)$, цинка $\left(\mathrm{Zn}^{2+}\right)$, меди $\left(\mathrm{Cu}^{2+}\right)$, никеля $\left(\mathrm{Ni}^{2+}\right)$, кобальта $\left(\mathrm{Co}^{2+}\right)$ в воде не превышает ПДК. Однако присутствие токсичных ионов ТМ в воде может привести к накоплению их в биомассе гидробионтов и гибели наиболее чувствительных видов среды обитания. При поливе культурных растений водой ионы ТМ адсорбируются на минеральной составляющей техногенной почвы, изменяя структуру почвенных коллоидов, или поступают через корни в наземную часть и вступают в конкуренцию с элементами коферментов, что приводит к нарушению биохимических реакций, угнетению растений и их гибели. Поэтому в дальнейших исследованиях проводили интегральную оценку качества воды малых рек с помощью биотестов растений. При длительном поливе водой рек Тьмака и Тверца замедлился рост корней (уменьшение длины в 1,5 раза) и вегетативной части (не происходит увеличение длины) тест растений [20, c.136]. 


\subsection{4 Биотестирование поверхностных вод \\ и техногенных почв города Твери}

Для интегрированной оценки техногенного загрязнения и расширения научных знаний в области физиологии и морфологии биологических объектов, функционирующих в техногенных экосистемах в Германии, Франции, США, Японии и других странах широко используются инструментарии качества биологического мониторинга. Преимущество биомониторинга состоит в универсальности, чувствительности биологических видов к загрязнению и быстрой реакции на изменения в экосистеме среды в целом, и дешевизне. Биологический мониторинг регистрирует форму и размер биологического «отклика» биологических систем, биологическую продуктивность под действием факторов окружающей среды и скорость накопления загрязнений. С помощью методов биоиндикации определяется влияние воздействия экологических факторов на состав, численность и скорость развития группы особей одного вида или сообщество организмов. Ответные реакции индикаторных видов зависят от экологического потенциала экосистемы и физиологической толерантности видов и проявляются изменением приоритетных показателей качества: морфологических признаков фракционного состава белков; структурно-функциональных свойств количества пыльцы и семян; генетических - частоты нарушения хромосом в клетках меристемы. При биотестировании исследуется влияние экологических факторов на отдельную функцию организма или систему организмов в контролируемых условиях. В качестве тест объектов применяются наиболее чувствительные организмы: высшие и низшие растения, бактерии, водоросли, водные и наземные беспозвоночные и другие. Преимущество живых индикаторов или тестов основано на их выживаемости, плодовитости, скорости роста или реакций, связанных с изменением клеточных функций в процессе их 


\section{СТАБИЛИЗАЦИЯ СВОЙСТВ ТОПЛИВНО-ЭНЕРГЕТИЧЕСКИХ СИСТЕМ НА ОСНОВЕ ПРИРОДНЫХ И СИНТЕТИЧЕСКИХ ПОЛИМЕРОВ}

роста и развития в загрязненных объектах. Поэтому с помощью них можно достоверно оценить качество объектов техногенных экосистем без использования дорогостоящего оборудования [21, с.13].

При биомониторинге почв целесообразно использовать представителей почвенной фауны, которые составляют 90 - 99\% биомассы и 95\% всех видов, входящих в наземный зооценоз. Наиболее универсальными являются тестрастения, которые позволяют проводить оценку всех природных сред (механического и кислотного состава почв, их плодородия, увлажнения и засоления, степени минерализации грунтовых вод и степени загрязнения атмосферного воздуха газообразными соединениями). При этом учитывается не уровень загрязнения, а вызываемый им биологические эффекты [22, с., 5, с. 233, 23, с.28]. Для контроля качества среды выбирают наиболее чувствительные, типичные для данной среды обитания виды биоиндикаторы или биотесты категории 1 и категории 2 (табл.1.1).

Таблица 1.1

\section{Стандартные тест-растения}

\begin{tabular}{|c|c|c|c|}
\hline Культура & $\begin{array}{c}\text { Латинское } \\
\text { название }\end{array}$ & Культура & $\begin{array}{c}\text { Латинское } \\
\text { название }\end{array}$ \\
\hline \multicolumn{2}{|c|}{ Категория 1} & \multicolumn{2}{|c|}{ Категория 2} \\
\hline Рожь & Secale cereale L. & Горчица белая & Sinapis alba \\
\hline $\begin{array}{c}\text { Рожь } \\
\text { многолетняя } \\
\end{array}$ & Lolium perenn L. & $\begin{array}{c}\text { Рапс (яровой или } \\
\text { озимый) }\end{array}$ & $\begin{array}{c}\text { Brassica napus (L.) } \\
\text { ssp. Napus }\end{array}$ \\
\hline Рис & Oryza sativa L. & Редис дикий & $\begin{array}{c}\text { Raphanus sativus } \\
\text { L. }\end{array}$ \\
\hline $\begin{array}{c}\text { Ячмень (яровой } \\
\text { или озимый) }\end{array}$ & Avena sativa L. & Репа дикая & $\begin{array}{l}\text { Brassica rapa ssp. } \\
\text { (DC) Metzg. }\end{array}$ \\
\hline $\begin{array}{c}\text { Пшеница мягкие } \\
\text { сорта }\end{array}$ & $\begin{array}{c}\text { Triticum } \\
\text { aestivum L. }\end{array}$ & Салат & Lactuca sativa L. \\
\hline $\begin{array}{c}\text { Овес (яровой или } \\
\text { озимый) }\end{array}$ & $\begin{array}{c}\text { Hordeum vulgare } \\
\text { L. }\end{array}$ & Kpecc & $\begin{array}{c}\text { Lepidium sativum } \\
\text { L. }\end{array}$ \\
\hline Сорго (или просо) & $\begin{array}{l}\text { Sorghum bicolor } \\
\text { (L.) Moench }\end{array}$ & Томаты & $\begin{array}{c}\text { Lycopersicon } \\
\text { esculentum Miller }\end{array}$ \\
\hline Кукуруза & Zea mays L. & Бобы & $\begin{array}{c}\text { Phaseolus aureus } \\
\text { Roxb. }\end{array}$ \\
\hline
\end{tabular}




\section{СТАБИЛИЗАЦИЯ СВОЙСТВ ТОПЛИВНО-ЭНЕРГЕТИЧЕСКИХ СИСТЕМ НА ОСНОВЕ ПРИРОДНЫХ И СИНТЕТИЧЕСКИХ ПОЛИМЕРОВ}

Интегрированную оценку качества техногенных экосистем:

поверхностной воды рек Волга, Тьмака, Тверца, почвы, растений г. Твери проводили инструментариями биомониторинга на модельных системах почва растение по изменению биометрических показателей качества: всхожести, длины надземной и корневой систем, массе сухого вещества надземной и подземной части тест растений категории 1 - ячменя и категории 2 - салата с учетом скорости прорастания и специфики почв изучаемого региона. Семена тест культур высевали в почву (контрольную и загрязненную), и учитывались биометрические показатели качества. Техногенные почвы были отобраны в радиусе санитарно-защитных зон промышленных объектов: тепловой электростанции ТЭЦ-1 (зона 1), механического завода (зона 2) г. Твери. Выращивали тест-растения в цилиндрических пластиковых стаканах диаметром 8 см и высотой 11 см без дна, вмещающие около 500 г почвы, состоящей на 80 процентов из фракций диаметром частиц $\phi=0,2 \ldots 0,6$ мм. Содержание частиц $\phi=0,6$ мм не должно превышать 10 процентов, а частиц $\phi=0,2$ мм не должно быть меньше 10 процентов согласно международному стандарту ГОСТ Р ИСО 22030-2009 [24]. В качестве контроля 1 использовали песок, контроль 2 стандартную почву ТУ 0391-030-57302407-05 с агрохимическими показателями качества: $\mathrm{pH}=5,5 \ldots 6,5$, содержание азота $-300 \ldots 550$ мг/кг, фосфора $\left(\mathrm{P}_{2} \mathrm{O}_{5}\right)$ - 300...550 мг/кг, калия $\left(\mathrm{K}_{2} \mathrm{O}\right)$ - 450-850 мг/кг. Полив растений осуществлялся водой дистиллированной, водопроводной, речной, отобранной в створах реки Тьмака (санитарно-защитной зоне механического завода и ТЭЦ-1) и в устье реки Тверца (Речной вокзал). Наблюдения за тест растениями (салат, ячмень) проводились в лабораторных условиях. Статистическая обработка биометрических измерений проводилась с помощью коэффициента фитотоксичности $\left(K_{\phi}\right)$, который рассчитывался по формуле

$$
\mathrm{K}_{\phi}=\frac{\mathrm{M}_{\mathrm{K}-\mathrm{M}_{\mathrm{x}}}}{\mathrm{M}_{\mathrm{K}}} \cdot 100 \% \text {, }
$$

где $\mathrm{M}_{\mathrm{K}}$ - масса контрольных растений; $\mathrm{M}_{\mathrm{x}}$ - масса растений, выращенных на загрязненной почве. 
По результатам фракционирования семян тест - растений была отобрана фракция с оптимальной длиной проростков на фильтре $3,0 \ldots 5,0$ см (рис. 1.14) для посева в почву.

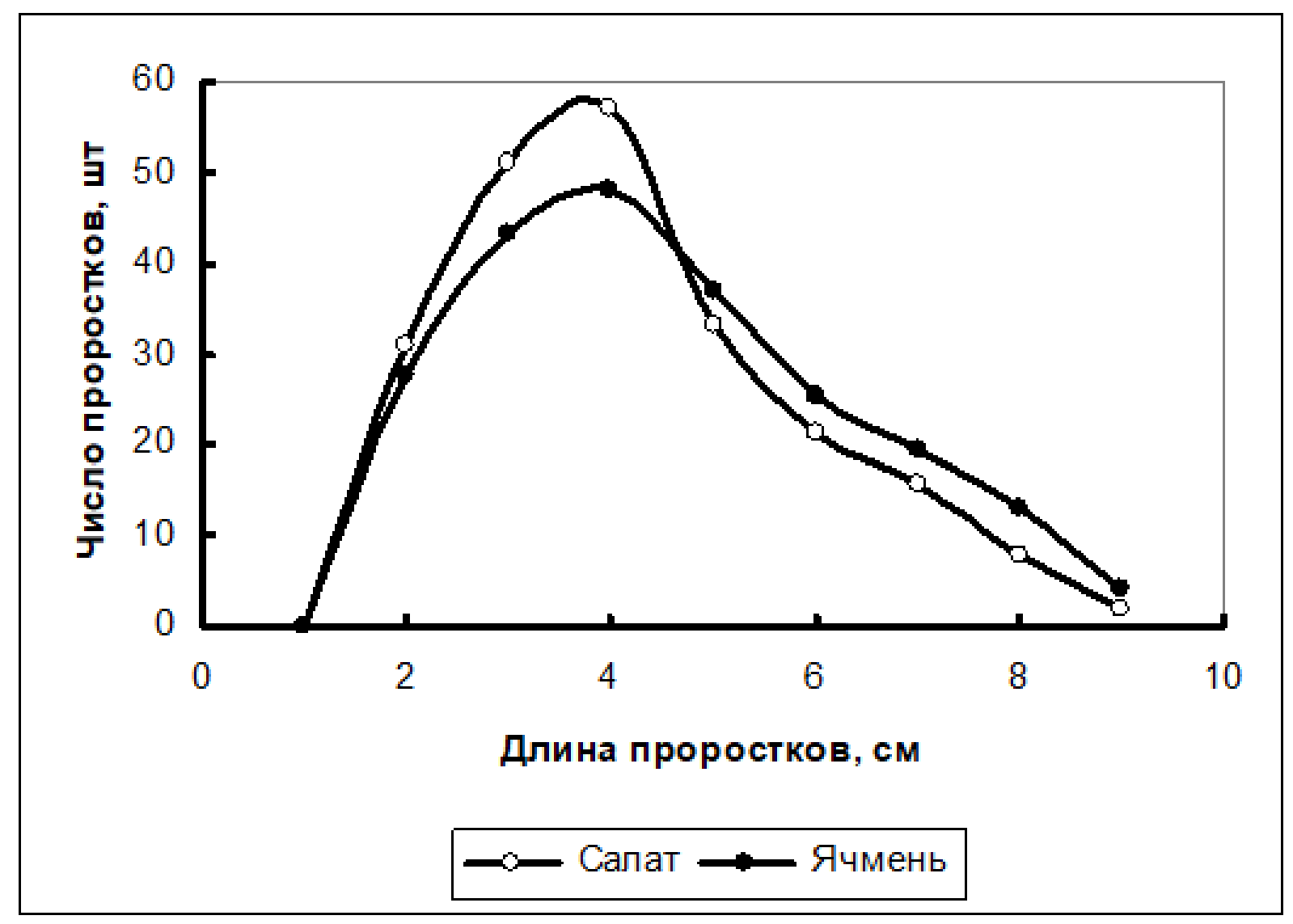

\section{Рис. 1.14. Фракционирование семян тест растений}

Посевная всхожесть отобранных фракций тест-салата или тест-ячменя в контрольных образцах почв (песок или стандартная почва ТУ 0391-030-57302407-05) составила 90..98 \%, а в техногенных образцах снизилась и составила $-60 \ldots 80 \%$ (для салата) и $30 \ldots 10 \%$ (для ячменя). По результатам фракционирования для оценки влияния качества воды на биометрические показатели техногенных почв города Твери использовали тест растения 1-й категории - ячмень и 2-й категории - салат. Изменение биометрических показателей: длины корней и стеблей салата в контрольных и техногенных образцах почв города Твери, представлены на рисунке 15. В контрольных субстратах развитие корневой системы и надземной вегетативной 
массы салата при поливе дистиллированной и водопроводной водой происходит равномерно (рис. 1.15a, б). Длина корней и стеблей в контроле 2 в два раза больше, чем в контроле 1, что связано с присутствием как минеральной, так и органической составляющей почвы.

Аналогичная зависимость биометрических показателей ячменя наблюдалась при поливе дистиллированной и водопроводной водой. При поливе водой из реки Тьмака длина корней и стеблей салата не изменилась, а ячменя значительно уменьшилась. Поэтому оценку качества техногенных почв проводили по изменению биомассы стеблей (рис. 1.16 а) и корней (рис. 1.16 б) ячменя.
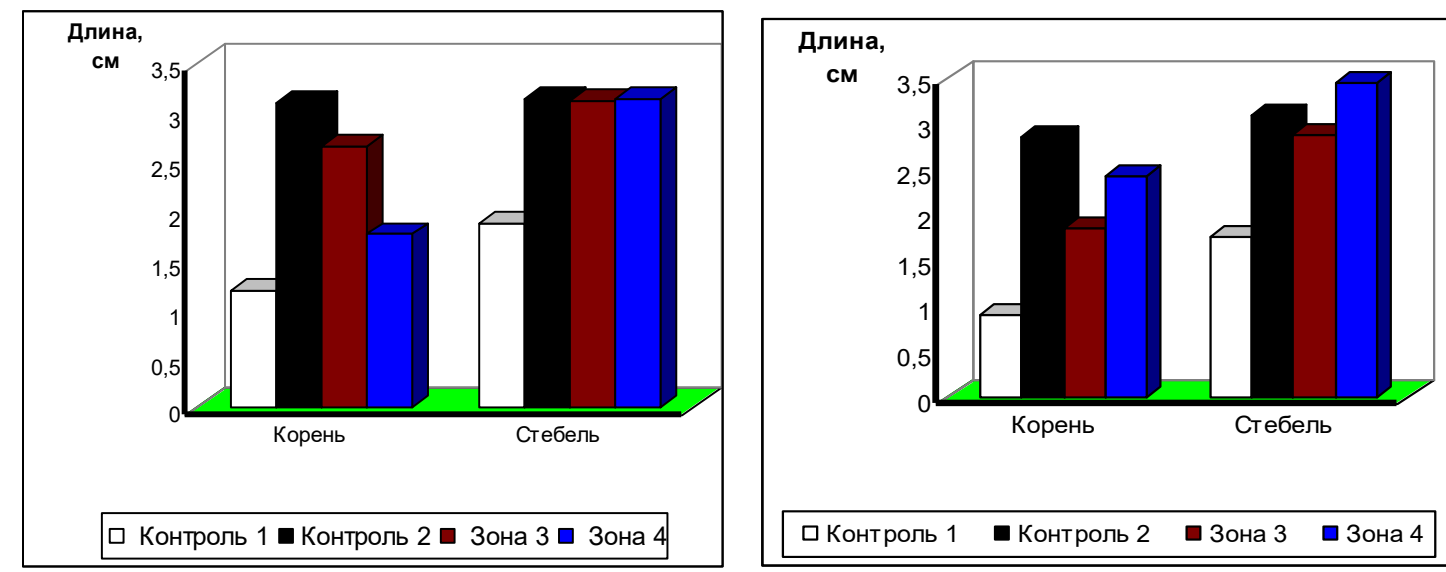

Рис. 1.15. Изменение длины корней и стеблей салата при поливе:

а) дистиллированной, б) водопроводной водой
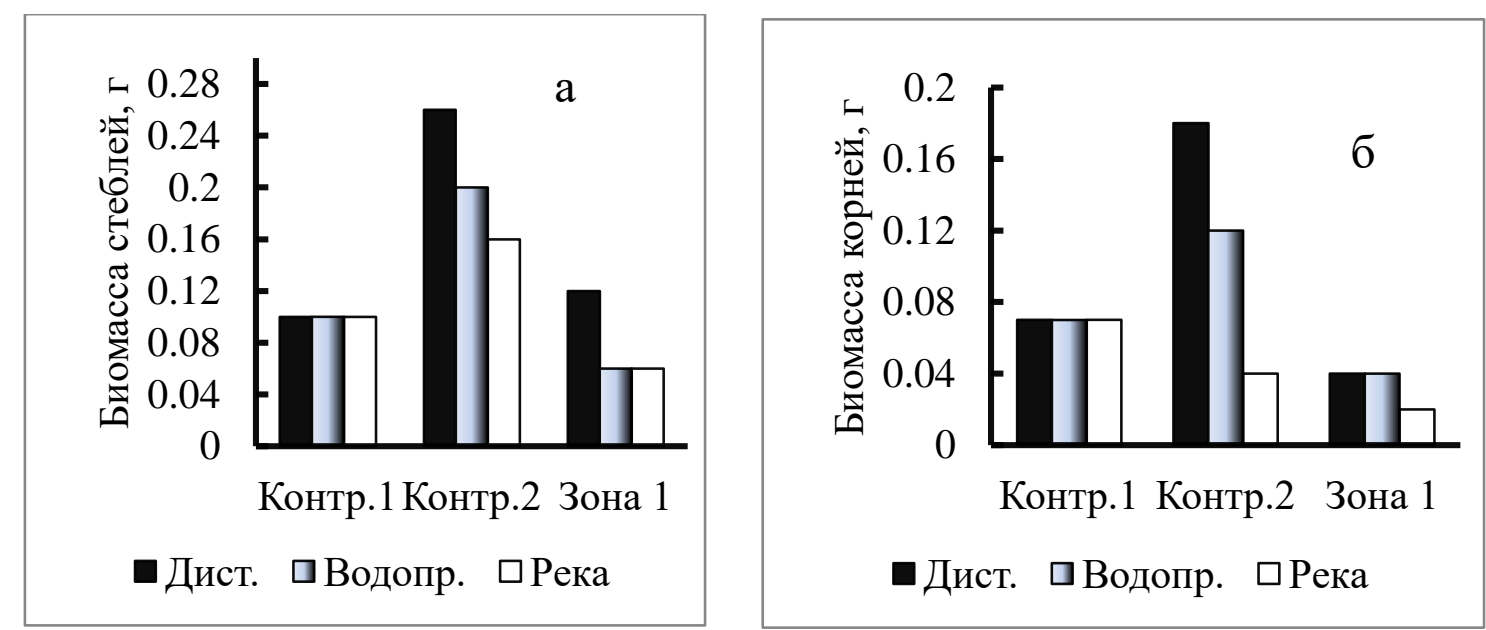

Рис. 1.16. Изменение биомассы ячменя в техногенной почве при поливе водой: а) стеблей; б) корней 


\section{СТАБИЛИЗАЦИЯ СВОЙСТВ ТОПЛИВНО-ЭНЕРГЕТИЧЕСКИХ СИСТЕМ НА ОСНОВЕ ПРИРОДНЫХ И СИНТЕТИЧЕСКИХ ПОЛИМЕРОВ}

При исследовании влияния качества воды на прирост биомассы обнаружено, что биомасса корней и стеблей ячменя постоянна в контроле 1 , содержащем только минеральную составляющую почвы и возрастает примерно в 2 раза в контроле 2, содержащем минеральную и органическую составляющие почв и уменьшается при поливе водой $\left(\mathrm{H}_{2} \mathrm{O}\right)$ в ряду:

$$
\mathrm{H}_{2} \mathrm{O}_{\text {dist }}>\mathrm{H}_{2} \mathrm{O}_{\text {водопр. }}>\mathrm{H}_{2} \mathrm{O}_{\text {реч. }} \text {. }
$$

Во всех вариантах биомасса стеблей превышает биомассу корней ячменя. В техногенной почве (рис.16) биомасса корней и стеблей ячменя в два - три раза уменьшилась по сравнению с контролем 2. Резкое снижение биомассы стеблей и корней ячменя усиливается с загрязненностью почвы, о чем свидетельствует угнетение и гибель тестов.

В связи с тем, что в процессе роста и развития растений различные органы формируются с различной скоростью, то в дальнейших исследованиях оценку качества техногенных почв проводили по степени прироста тест-салата и тест-ячменя. Степень прироста рассчитывали по соотношению корневой и вегетативной части растений по сравнению с контрольным субстратом. При поливе тест-растений водой из реки Тьмака степень прироста тест-ячменя (рис. 1.17б) и тест-салата (рис. 1.17a), ниже, чем в контрольных субстратах.
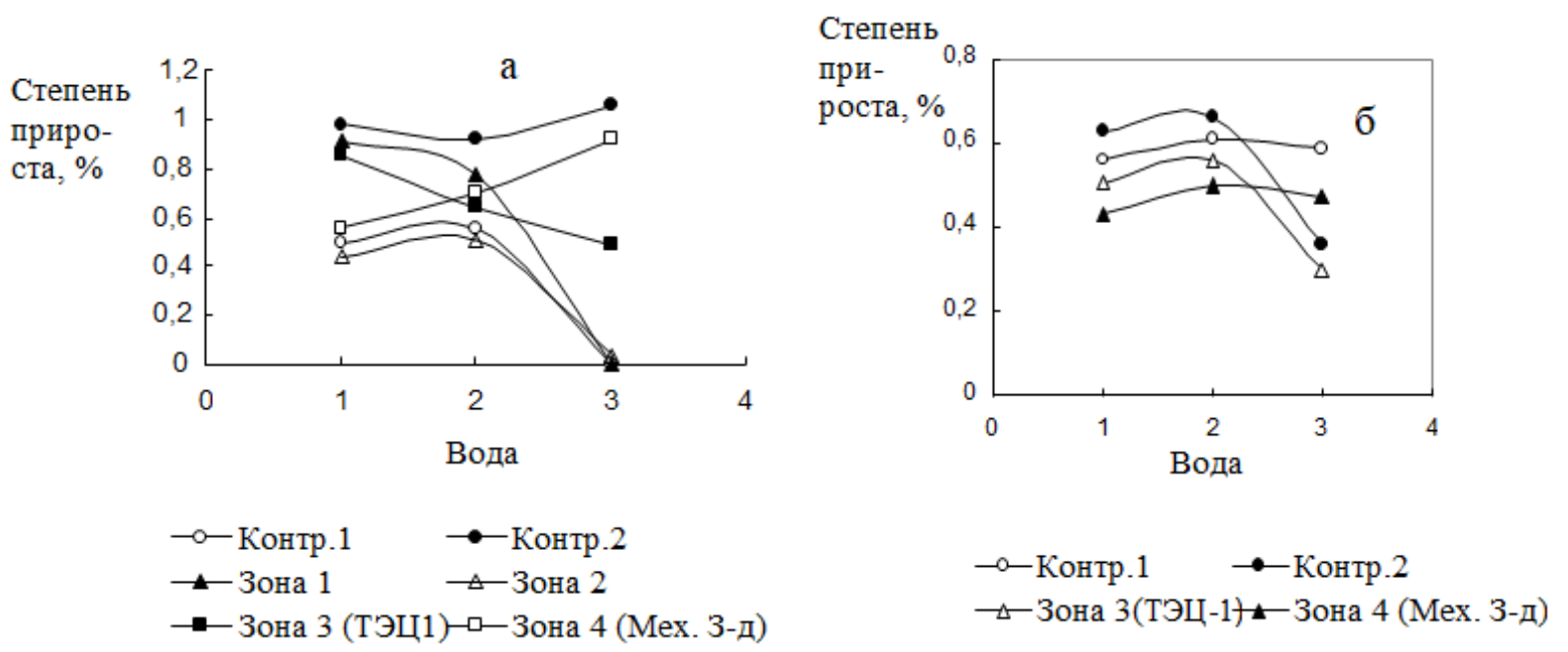

Рис. 1.17. Изменение степени прироста тест-растений при поливе водой: 1 -дистиллированной, 2 - водопроводной, 3 - речной; а) салата, б) ячменя 


\section{СТАБИЛИЗАЦИЯ СВОЙСТВ ТОПЛИВНО-ЭНЕРГЕТИЧЕСКИХ СИСТЕМ НА ОСНОВЕ ПРИРОДНЫХ И СИНТЕТИЧЕСКИХ ПОЛИМЕРОВ}

При длительном поливе речной водой тест-растения находятся в угнетенном состоянии или погибают, что свидетельствует о загрязненности речной воды реки Тьмака. Степень прироста салата в почвах техногенных зон меньше, чем в контрольных субстратах и уменьшается при поливе речной водой в ряду техногенных почв: Зона 3 > зона 4 > зона 1.

Проведенные биометрические исследования позволили дать интегрированную оценку загрязнения поверхностных вод реки Тьмака вблизи источников загрязнения ТЭЦ-1 (зона 1), механического завода (зона 2) г. Твери, которые коррелируются с данными химического мониторинга о несоответствии качества воды требованиям СанПиН 2.1.5.5980-00. В поверхностных водах реки Тьмака обнаружены токсичные ионы тяжелых металлов (ТМ): свинца $\left(\mathrm{Pb}^{2+}\right)$, цинка $\left(\mathrm{Zn}^{2+}\right)$, меди $\left(\mathrm{Cu}^{2+}\right)$, никеля $\left(\mathrm{Ni}^{2+}\right)$, кобальта $\left(\mathrm{Co}^{2+}\right)$, содержание которых находится в пределах ПДК. По всей видимости присутствие этих ионов приводит к снижению защитных функций тест-растений и оказывает влияние на скорость нарастания биомассы, объема, размеров растения так как являются аналогами микро- и макроэлементов, входящих в состав живых организмов и способны их замещать в тканях и органах животных и растений, нарушая обмен веществ [25, с.39]. Многие ТМ являются необходимыми элементами жизненного цикла растений. К числу необходимых растению ТМ относят макроэлементы: калий $(\mathrm{K})$, кальций $(\mathrm{Ca})$, магний $(\mathrm{Mg})$, железо $(\mathrm{Fe})$ и микроэлементы: медь (Cu), марганец $(\mathrm{Mn})$, цинк $(\mathrm{Zn})$, которые влияют на обмен веществ и каталитические функции ферментов. В природной системе: почва растение, растения адаптировались к подвижным формам ТМ содержащимся в почве и находятся в гомеостазе, используя их в жизненном цикле избирательно. Избыточное их количество проявляется не сразу, а на поздних этапах онтогенеза [26 - 28].

В дальнейших исследованиях изучено влияние солей токсичных ТМ на биометрические показатели тест растений. В качестве подвижных форм токсичных тяжелых металлов использовали соли марганца $(\mathrm{Mn})$, меди $(\mathrm{Cu})$, магния (Mg), цинка (Zn) из расчета 50, 100, 500, 1000 мг на 1кг воздушно сухой 
почвы с последующим ее увлажнением до 70 \%-ной влажности и посевом тест растений $[23$, с. 28]. Полив тест-растений осуществляли дистиллированной $\left(\mathrm{H}_{2} \mathrm{O}_{\text {dist. }}\right)$, водопроводной $\left(\mathrm{H}_{2} \mathrm{O}_{\text {водопр. }}\right)$, природной водой $\left(\mathrm{H}_{2} \mathrm{O}_{\text {реч. }}\right)$, отобранной в летнее время в реке Волга (Речной вокзал). Изменение биометрических показателей качества тест растений приведены на рисунках 1.18-1.20. В диапазоне концентраций солей $50 \ldots 100$ мг/кг длина корней ячменя уменьшилась в два раза по сравнению с контролем, а длина стеблей увеличилась (рис. 1.18a).
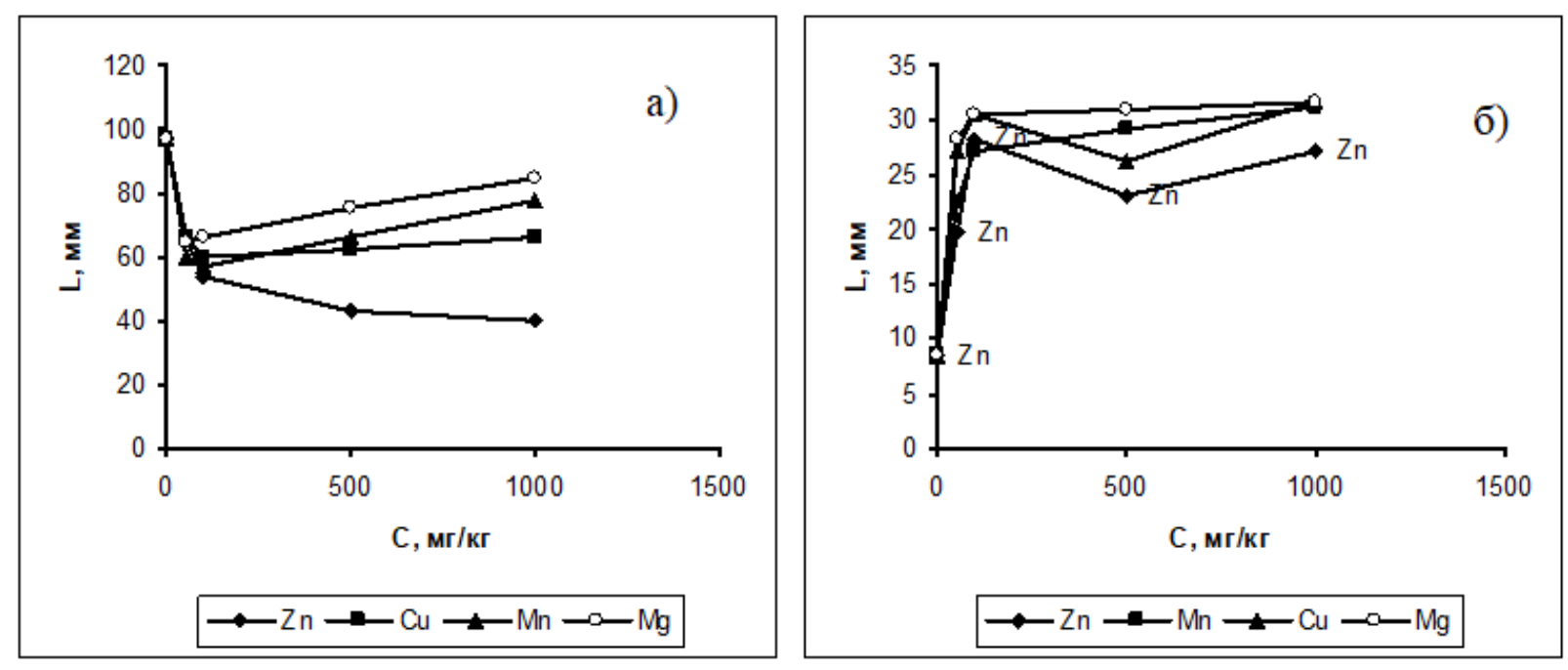

Рис. 1.18. Изменение длины корней от концентрации солей $\mathrm{ZnSO}_{4}, \mathrm{CuSO}_{4}, \mathrm{MgCl}_{2}, \mathrm{MnCl}_{2}$ в модельных субстратах: а) ячменя, б) салата

Однако, при дальнейшем увеличении содержания солей меди не наблюдается прироста корней. При увеличении содержания солей марганца и магния в почве (500 - 1000 мг/кг) происходит монотонное увеличение длины корней ячменя. По-видимому, это связано с тем, что $\mathrm{Mg}$ и $\mathrm{Mn}$ входят в состав фитогормона, регулирующего рост растений. Избыток содержания соли цинка приводит к снижению длины корней ячменя. Аналогичное влияние концентрации этих солей обнаружено и на рост вегетативной массы ячменя. Несколько иная картина наблюдается при воздействии этих солей на тестрастение второй категории - салат (рис. 1.18 б). При малом содержании солей 
$\mathrm{Mg}, \mathrm{Mn}, \mathrm{Zn}$ и $\mathrm{Cu}(50$ мг/кг) наблюдается увеличение длины корней салата по сравнению с контрольным образцом почти в три раза. В области средних концентраций $(100-500$ мг/кг) солей ТМ длина корней тест-салата не изменяется и соответствует длине теста-салата в контрольном субстрате. При более высоких дозах ТМ прирост биомассы прекращался и тест растения погибали. В целом биометрические показатели качества тест-ячменя и тестсалата уменьшаются при поливе водой, содержащей соли ТМ в ряду:

$$
\mathrm{Mn}>\mathrm{Cu}>\mathrm{Mg}>\mathrm{Zn} \text {. }
$$

Степень прироста теста-ячменя (рис. 1.19a) и коэффициента фитотоксичности (рис. 1.19б) так же зависят от концентрации солей ТМ в модельных субстратах. Максимальная степень прироста ячменя наблюдается при внесении в почву 50 мг/кг солей $\mathrm{Mg}, \mathrm{Cu}, \mathrm{Mn}$ (рис. 1.19a), а при внесении соли Zn при концентрации 100 мг/кг. Дальнейшее увеличение концентраций солей не приводит к приросту теста-ячменя. На кривых фитотоксичности модельных субстратов имеются максимумы, в которых растения ячменя находятся в активном состоянии, а за его пределами погибают (рис. 1.19 б).
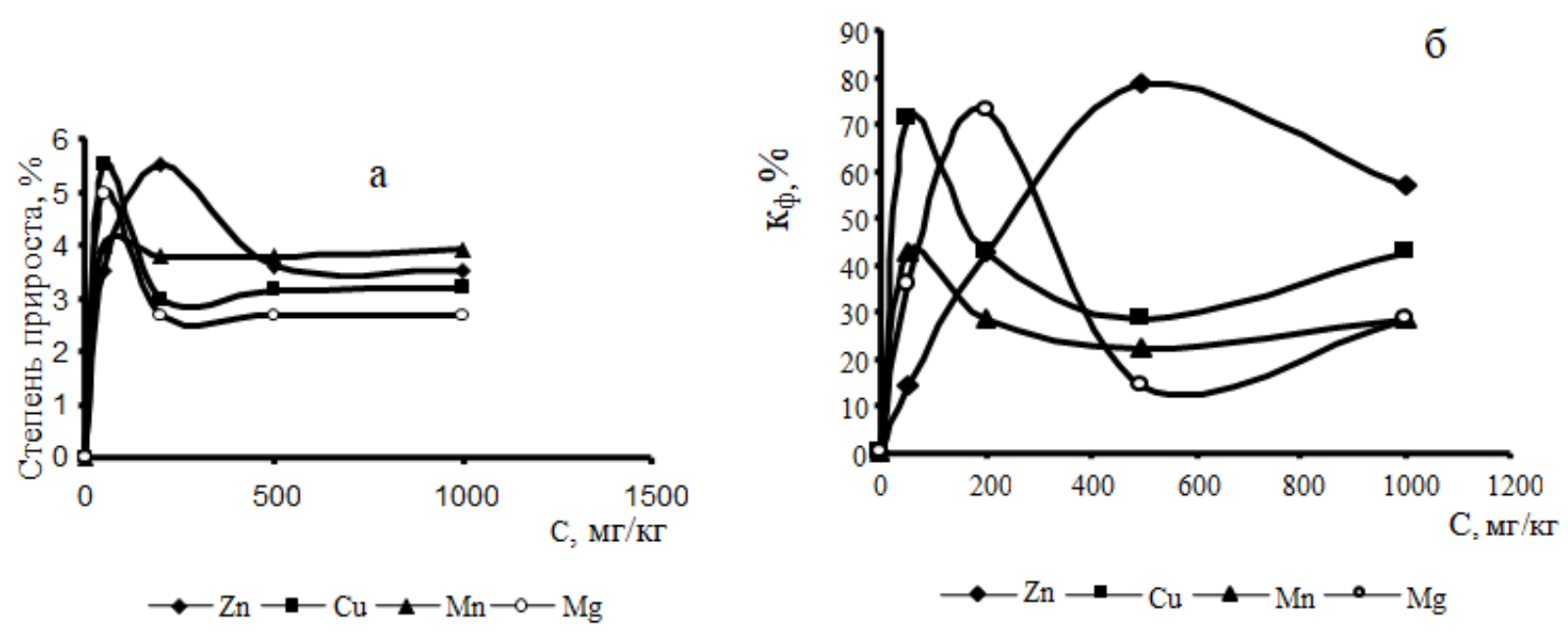

Рис. 1.19. Изменение в модельных системах почва - ячмень от концентрации $\mathrm{ZnSO}_{4}, \mathrm{CuSO}_{4}, \mathrm{MgCl}_{2}, \mathrm{MnCl}_{2}$ a) степени прироста; б) коэффициента фитотоксичности $\left(K_{\phi}\right)$ 


\section{СТАБИЛИЗАЦИЯ СВОЙСТВ ТОПЛИВНО-ЭНЕРГЕТИЧЕСКИХ СИСТЕМ НА ОСНОВЕ ПРИРОДНЫХ И СИНТЕТИЧЕСКИХ ПОЛИМЕРОВ}

Наиболее устойчивы тесты-ячменя к соли $\mathrm{ZnSO}_{4}$, так как погибают при более высоких значениях $K_{\phi}-600 \ldots 800$ мг/кг, а наименее устойчивы - к соли $\mathrm{MnCl}_{2}$, зона максимума на кривой коэффициента фитотоксичности значительно уже и находится в пределах концентраций 50...100 мг/кг. В целом коэффициент фитотоксичности для модельной системы почва - ячмень увеличивается при внесении солей ТМ в ряду: $\mathrm{Mn}>\mathrm{Cu}>\mathrm{Mg}>\mathrm{Zn}$ [21, с. 78]. Устойчивость салата к исследуемым солям ТМ значительно ниже. О чем свидетельствуют отрицательные значения коэффициента токсичности (рис. 1.20).

На всех кривых фитотоксичности имеется минимум, соответствующий концентрации солей $\mathrm{MnCl}_{2}$ и $\mathrm{CuSO}_{4} 50$ мг/кг, а для солей $\mathrm{MgCl}_{2}$ и $\mathrm{ZnSO}_{4}$ 100 мг/кг. Коэффициент фитотоксичности для модельной системы почва-салат в той же последовательности: $\mathrm{Mn}>\mathrm{Cu}>\mathrm{Mg}>\mathrm{Zn}$. Однако зона толерантности в два раз уже и максимум $\mathrm{K}_{\phi}$ находится в диапазоне концентраций $\mathrm{ZnSO}_{4}$ $100 \ldots 300$ мг/кг.

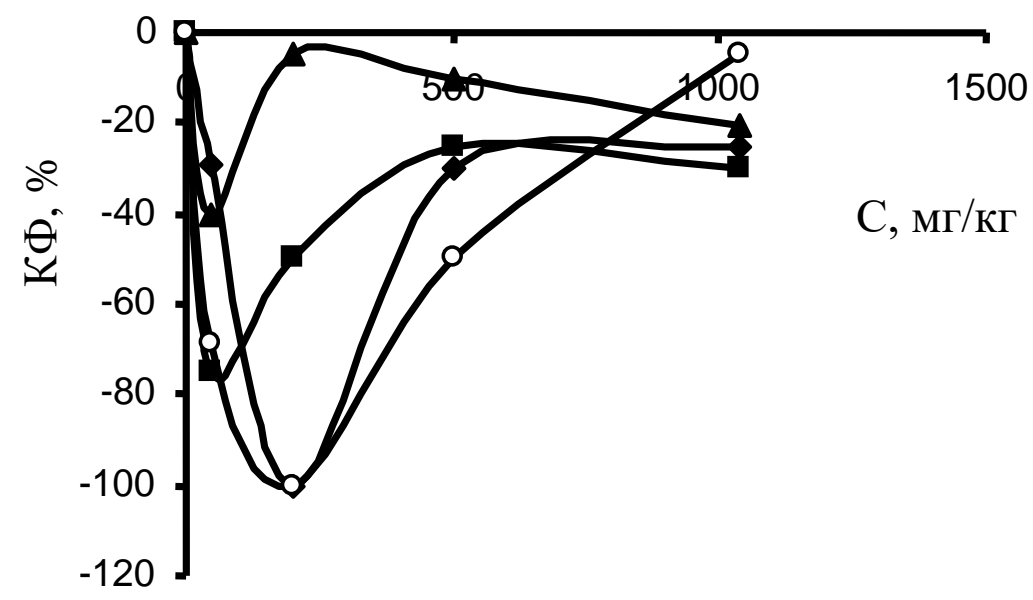

$$
\rightarrow \mathrm{Zn} \rightarrow-\mathrm{Cu} \longrightarrow \mathrm{Mn} \multimap \mathrm{Og}
$$

Рис. 1.20. Изменение коэффициента фитотоксичности $\left(K_{\phi}\right)$ от концентрации солей $\mathrm{ZnSO}_{4}, \mathrm{CuSO}_{4}, \mathrm{MgCl}_{2}, \mathrm{MnCl}_{2}$ 


\section{СТАБИЛИЗАЦИЯ СВОЙСТВ ТОПЛИВНО-ЭНЕРГЕТИЧЕСКИХ СИСТЕМ НА ОСНОВЕ ПРИРОДНЫХ И СИНТЕТИЧЕСКИХ ПОЛИМЕРОВ}

\section{Проведенный мониторинг техногенных объектов гарантирует}

экологически-безопасное функционирование производственно-промышленных объектов, стабильные технологические показатели качества и безопасность готовой продукции. Оценка качества поверхностной воды рек Волга, Тверца, Тьмака с использованием химических инструментариев определения индивидуальных стандартных показателей коррелирует с интегрированной оценкой загрязнения поверхностной воды с помощью тест растений. Использование биологических инструментариев качества позволило минимизировать экономические затраты и сроки на проведение на проведение экологического мониторинга. Проведенные наблюдения в рамках производственного мониторинга на примере лекарственных препаратов с использованием химических инструментариев позволили минимизировать риск при изготовлении лекарственных препаратов: антибиотиков группы цефалоспоринов - цефтриаксона и ноотропной группы - пирацетама, гарантировать стабильные показатели качества соответствие фармакопейной статье предприятия и удовлетворить требования потребителя. 


\section{ГЛАВА 2.}

\section{МЕТОДОЛОГИЯ СТАБИЛИЗАЦИИ ФИЗИКО-ХИМИЧЕСКИХ СВОЙСТВ СИНТЕТИЧЕСКИХ ПОЛИМЕРНЫХ СИСТЕМ}

На втором этапе методологии стабилизации свойств природных энергетических систем применялась концепция рационального использования природных энергетических ресурсов на принципах замены незаменимых природных ресурсов на возобновляемые ресурсы, в частности природного полимера - на синтетические аналоги; и минимизации летучих компонентов в составе промышленных материалов. Минимизация техногенного риска осуществлялась путем стабилизации физико-химических свойств водноорганических синтетических полимерных систем.

\section{1 Теоретические аспекты растворимости компонентов водоразбавляемых пленкообразующих систем}

С этой целью был проведен анализ критериев растворимости синтетических полимеров с низкомолекулярными органическими растворителями и разработана концепция повышения стабильности синтетических полимерных систем на принципах физико-химического анализа на примере водоразбавляемых олигоэфирных пленкообразующих систем.

Лакокрасочные материалы (ЛКМ) представляют собой многокомпонентные дисперсные системы, содержащие синтетические полимеры, пигменты, наполнители, органические растворители, отвердители, способные после нанесения на поверхность металла образовывать покрытие, защищающее от коррозии. Особое место в ассортименте ЛКМ занимают водоразбавляемые олигоэфирные материалы - аналоги алкидных ЛКМ, в которых токсичные летучие органические растворители частично замены на 
воду, что позволяет снизить содержание токсичных летучих веществ в рабочей зоне, обеспечить безопасность окрасочных работ, использовать электрохимический способ нанесения. С другой стороны, присутствие воды снижает стабильность при хранении и разбавлении растворителем до рабочей вязкости перед нанесением [29, с. 11].

Традиционным критерием оценки растворимости полимера и образования стабильного раствора с органическими растворителями принят параметр растворимости Гильдебранда $(\delta)$, который определяется по формуле

$$
\delta=\sqrt{\frac{\Delta \mathrm{E}_{0}}{\mathrm{~V}}}
$$

где $\Delta \mathrm{E}_{0}=\Delta \mathrm{H}_{0}-\mathrm{RT} ; \Delta \mathrm{H}_{0}-$ скрытая теплота испарения жидкости; $\mathrm{R}$ - универсальная газовая постоянная; Т - абсолютная температура; $\mathrm{V}$ - мольный объем жидкости.

Трудность оценки заключается в том, что экспериментально величину $\delta$ можно определить только для низкомолекулярных жидкостей, испаряющихся без разложения. Для полимеров, которые нельзя испарить без разложения, значения $\delta$ определяются косвенными методами или расчетным путем, предполагая отсутствие специфических сил взаимодействия. В этой концепции рассматривается лишь физический аспект взаимодействия макромолекул и молекул растворителя [30]. Влияние растворителя проявляется в изменении способности полимерных цепей к конформационным переходам, то есть влияние на их равновесную гибкость. Однако присутствие эфирной связи (一O-) придает макромолекулам олигомера гибкость, а полярных функциональных групп (- $\mathrm{COOH},-\mathrm{OH})$ обеспечивает образование внутри макромолекулы достаточно прочные водородные $\mathrm{H}-$ связи. Под действием молекул полярного растворителя происходит ослабевание внутримолекулярных $\mathrm{H}$ - связей и макромолекулы становятся более гибкими, образуя устойчивую спиралевидную конформацию, которая легко сворачивается в глобулы. При этом часть растворителя может находится внутри макромолекул и 


\section{СТАБИЛИЗАЦИЯ СВОЙСТВ ТОПЛИВНО-ЭНЕРГЕТИЧЕСКИХ СИСТЕМ НА ОСНОВЕ ПРИРОДНЫХ И СИНТЕТИЧЕСКИХ ПОЛИМЕРОВ}

образовывать новые водородные связи между структурными сегментами макромолекул, а часть находится в свободном состоянии. Кроме того, в бинарных низкомолекулярных системах: вода-амин или вода-полярный органический растворитель наблюдаются сильные положительные или отрицательные отклонения термодинамических функций от аддитивности, что свидетельствует о межмолекулярных взаимодействиях, приводящих к эффектам расслоения [31]. Поэтому использование концепции параметра растворимости не позволяет достоверно оценить влияние межмолекулярных взаимодействий многокомпонентных систем с низкомолекулярными компонентами (вода - амин - полярный растворитель) на структуру и стабильность олигоэфирных пленкообразующих систем (ПОС).

В связи с этим, для управления стабильностью качества водноорганических синтетических полимерных систем и минимизации техногенного риска использовались термодинамические инструментарии, основанные на принципах непрерывности и соответствия физико-химических, физикомеханических свойств, с последующим анализом геометрического облика кривых свойств $\mathrm{Y}(\rho, \eta, \mathrm{V})=f$ (состава) и кривых избыточных функций $\mathrm{Y}^{\mathrm{E}}\left(\rho^{\mathrm{E}}, \eta^{\mathrm{E}}, \mathrm{V}^{\mathrm{E}}\right)=f($ cocmaвa) гомогенных бинарных систем и диаграмм фазовых равновесий гетерогенных систем [32, 33]. Оптимизацию параметров стабилизации равновесных полимерных систем осуществлялась с помощью физико-химического анализа диаграмм состав-свойство и диаграмм фазовых равновесий модельных бинарных, тройных систем (рис.2.1). При непрерывном изменении параметров, определяющих состояние системы - давление, температура, концентрация, свойства отдельных ее фаз изменяются непрерывно до тех пор, пока не изменится число и характер фаз. При возникновении новых или исчезновение старых фаз свойства системы изменяются, как правило, скачком и отражают геометрические параметры пространственной структуры межмолекулярных соединений в растворе. На первом этапе диагностики стабильности показателей качества водоразбавляемых ПОС исследовались 


\section{СТАБИЛИЗАЦИЯ СВОЙСТВ ТОПЛИВНО-ЭНЕРГЕТИЧЕСКИХ СИСТЕМ НА ОСНОВЕ ПРИРОДНЫХ И СИНТЕТИЧЕСКИХ ПОЛИМЕРОВ}

изменение физико-химических свойств: плотности ( $\rho)$, вязкости (ๆ), мольного объема $(\mathrm{V})$ и их избыточных функций: $\rho^{\mathrm{E}}, \eta^{\mathrm{E}}, \mathrm{V}^{\mathrm{E}}$ от состава гомогенных бинарных низкомолекулярных систем. На втором этапе исследований проводился анализ фазового состояния бинарных и тройных систем с низкомолекулярными компонентами, так как согласно принципу соответствия, каждой фазе или каждому комплексу равновесных фаз соответствует на диаграмме определенный геометрический образ.

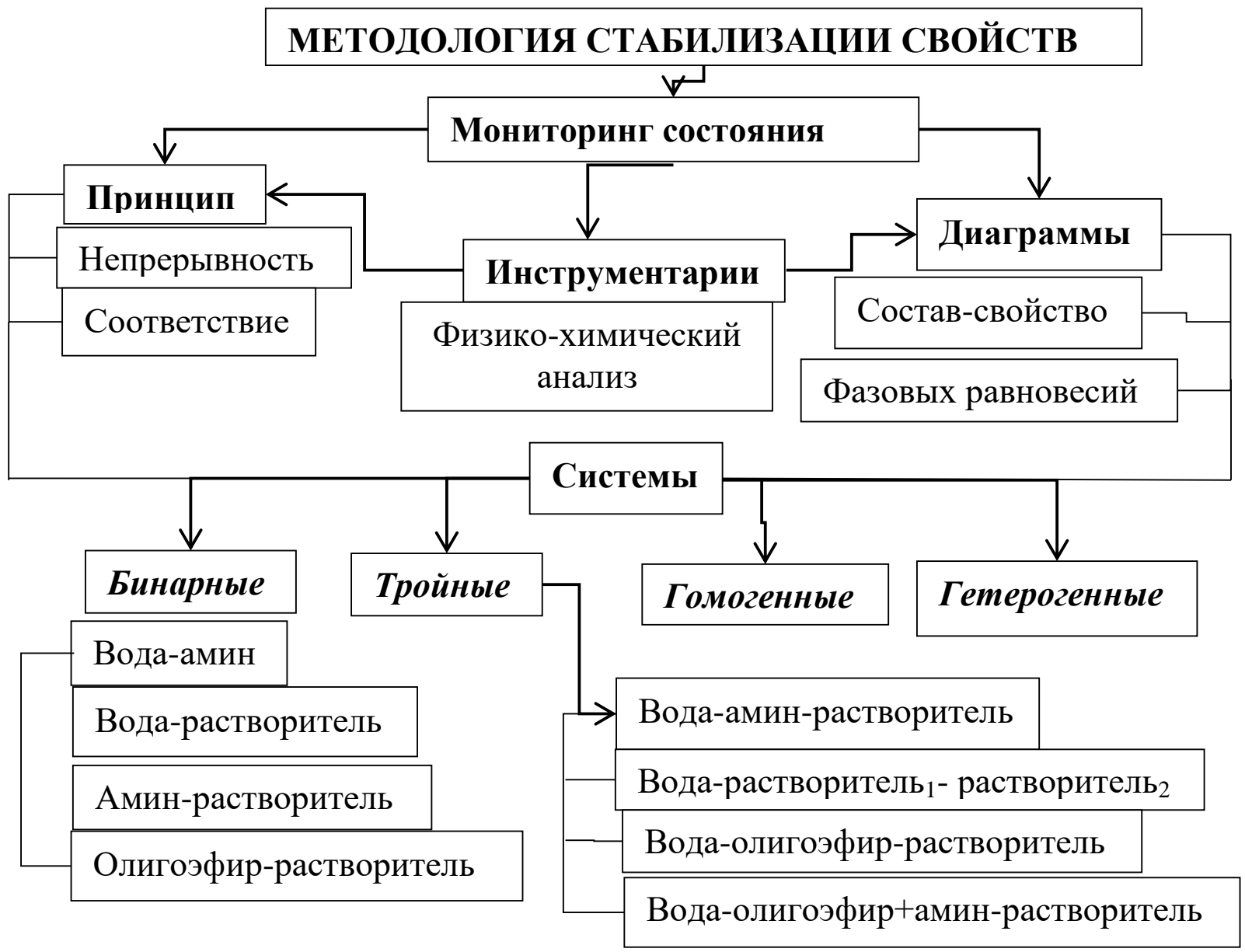

Рис. 2.1. Схема алгоритма стабилизации физико-химических свойств синтетических олигоэфирных систем

Исследования характера межмолекулярных взаимодействий проводились с помощью анализа геометрического облика кривых свойств $\mathrm{Y}(\rho, \eta, \mathrm{V})=f$ (состава) гомогенных бинарных низкомолекулярных систем типа: $\mathrm{H}_{2} \mathrm{O}$ - Амин; 
$\mathrm{H}_{2} \mathrm{O}$ - полярный органический растворитель; Амин - полярный органический растворитель. По наличию экстремумов и сингулярных точек на кривых свойств $\mathrm{Y}(\rho, \eta, \mathrm{V})=f$ (состава) выявлены сильные (вода-амин) и слабые межмолекулярные взаимодействия (амин - полярный органический растворитель). Состав образующихся межмолекулярных комплексов определялся по положению сингулярных точек на кривых избыточных функций $\mathrm{Y}^{\mathrm{E}}\left(\rho^{\mathrm{E}}, \eta^{\mathrm{E}}, \mathrm{V}^{\mathrm{E}}\right)=f($ состава), рассчитанных в предположении отсутствия взаимодействий по правилу аддитивности [10]. Расчет избыточных функций $\rho^{\mathrm{E}}$, $\eta^{\mathrm{E}}, \mathrm{V}^{\mathrm{E}}$ или их отклонений от аддитивности $(\Delta \rho, \eta, V)$, то есть, разности между действительной величиной данного свойства и его значением, выполнены по правилу смешения по формулам:

$$
\Delta \mathrm{V}\left(\text { или } \mathrm{V}^{\mathrm{E}}\right)=\mathrm{V}_{\text {эксп. }}-\mathrm{V}_{\text {ад }},
$$

где $V_{\text {эксп. }}-$ мольный объем, $V_{\text {ад }}$ - аддитивный мольный объем,

$$
\mathrm{V}_{\text {эксп. }}=\frac{\mathrm{M}_{\mathrm{A}} \cdot \mathrm{N}_{\mathrm{A}}+\mathrm{M}_{\mathrm{B}} \cdot \mathrm{N}_{\mathrm{B}}}{\rho},
$$

где $\mathrm{M}_{\mathrm{A}}$ и $\mathrm{M}_{\mathrm{B}}$ - молекулярные массы чистых веществ (А и В),

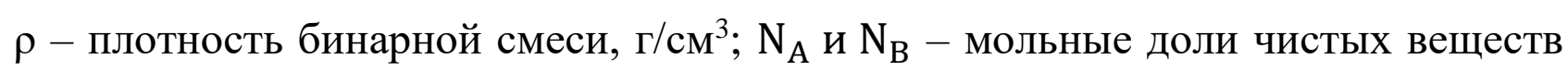
(А и B),

$$
\mathrm{V}_{\text {ад }}=\frac{\mathrm{M}_{\mathrm{A}}}{\rho_{\mathrm{A}}} \cdot \mathrm{N}_{\mathrm{A}}+\frac{\mathrm{M}_{\mathrm{B}}}{\rho_{\mathrm{B}}} \cdot \mathrm{N}_{\mathrm{B}},
$$

где $\mathrm{V}_{\text {ад }}$ - аддитивный мольный объем: $\mathrm{M}_{\mathrm{A}}$ и $\mathrm{M}_{\mathrm{B}}$ - молекулярные массы чистых веществ (А и В), $\rho$ - плотности чистых веществ (А и В); $\mathrm{N}_{\mathrm{A}}$ и $\mathrm{N}_{\mathrm{B}}-$ мольные доли чистых веществ (А и В);

$$
\Delta \eta=\eta_{\text {эксп. }}-\eta_{\text {расч. }}
$$

где $\eta_{\text {эксп. }}-$ динамическая вязкость, Па·с; $\eta_{\text {расч. }}$ - вязкость, рассчитанная по методу Фиалкова Ю.Я.;

$$
\eta_{\text {эксп. }}=\mathrm{k} \cdot \mathrm{t} \cdot \rho
$$

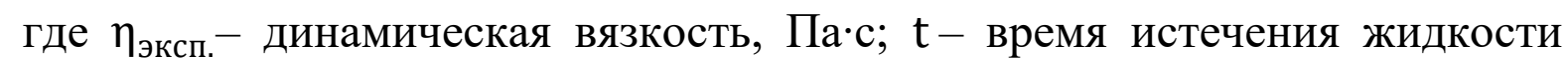
через капилляр, c; $\mathrm{k}$ - постоянная вискозиметра; 


$$
\eta_{\text {расч. }}=\eta_{\text {ад. }} \cdot \mathrm{L}_{\mathrm{i}}
$$

где $\eta_{\text {расч. }}$ - вязкость, рассчитанная по методу Фиалкова Ю.Я., $\eta_{\text {ад. }}-$ аддитивная вязкость, $\mathrm{L}_{\mathrm{i}}-$ эмпирический коэффициент;

$$
\eta_{\text {ад. }}=\eta_{\mathrm{A}} \cdot \mathrm{N}_{\mathrm{A}}+\eta_{\mathrm{B}} \cdot \mathrm{N}_{\mathrm{B}}
$$

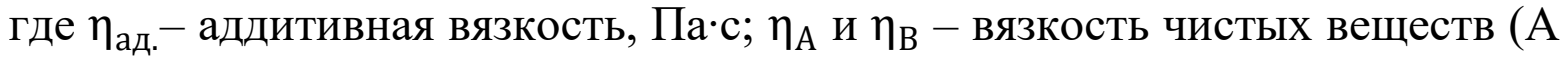
и В), Па·с; $\mathrm{N}_{\mathrm{A}}$ и $\mathrm{N}_{\mathrm{B}}$ - мольные доли чистых веществ (А и В);

$$
\mathrm{L}_{\mathrm{i}}=\frac{8}{\mathrm{~s}_{\mathrm{\eta}}+7}
$$

где $\mathrm{L}_{\mathrm{i}}$ - эмпирический коэффициент, рассчитанный относительно более вязкого компонента, $\mathrm{i}-0,25$ или 0,5 моль; где $\mathrm{S}_{\eta}-$ эмпирический коэффициент более вязкого компонента при условии, что $\eta_{\mathrm{A}}>\eta_{\mathrm{B}}$;

$$
\begin{gathered}
\mathrm{S}_{\eta}=\frac{\eta_{\mathrm{A}}}{\eta_{\mathrm{B}}}, \\
\mathrm{L}_{0,75}=\frac{8}{\mathrm{~s}_{\eta}+7}+\frac{\mathrm{s}_{\eta}-1}{5 \cdot \mathrm{S}_{\eta}+20},
\end{gathered}
$$

где $\mathrm{L}_{0,75}-$ эмпирический коэффициент, рассчитанный относительно 0,75 моль более вязкого компонента, $S_{\eta}$ - эмпирический коэффициент более вязкого компонента; $\eta_{\mathrm{A}}$ и $\eta_{\mathrm{B}}-$ вязкость чистых веществ (А и В), Па·с [10].

Для исследования отражения межмолекулярных взаимодействий низкомолекулярных компонентов на стабильность полимерных систем были использованы термодинамические инструментарии качества (рис. 2.2). Применение законов термодинамики к фазовым равновесиям, обоснованное Гиббсом, позволило найти критерий самопроизвольного протекания процесса растворения веществ, так называемую функцию Гиббса $(\Delta G)$. При самопроизвольном протекании процесса значения функции $\Delta G$ убывают $(\Delta G=\Delta H-T \Delta S<0)$ и равны нулю $(\Delta \mathrm{G}=0)$ при установлении в системе динамического равновесия. Самопроизвольное растворение молекул в растворителе сопровождается выделением (экзотермический эффект) или поглощением (эндотермический процесс) энергии в виде тепла, расходуемого 


\section{СТАБИЛИЗАЦИЯ СВОЙСТВ ТОПЛИВНО-ЭНЕРГЕТИЧЕСКИХ СИСТЕМ НА ОСНОВЕ ПРИРОДНЫХ И СИНТЕТИЧЕСКИХ ПОЛИМЕРОВ}

на разрушение межмолекулярных связей твердого (кристаллической решетки) или жидкого тела с образованием гомогенного (стабильного) раствора.

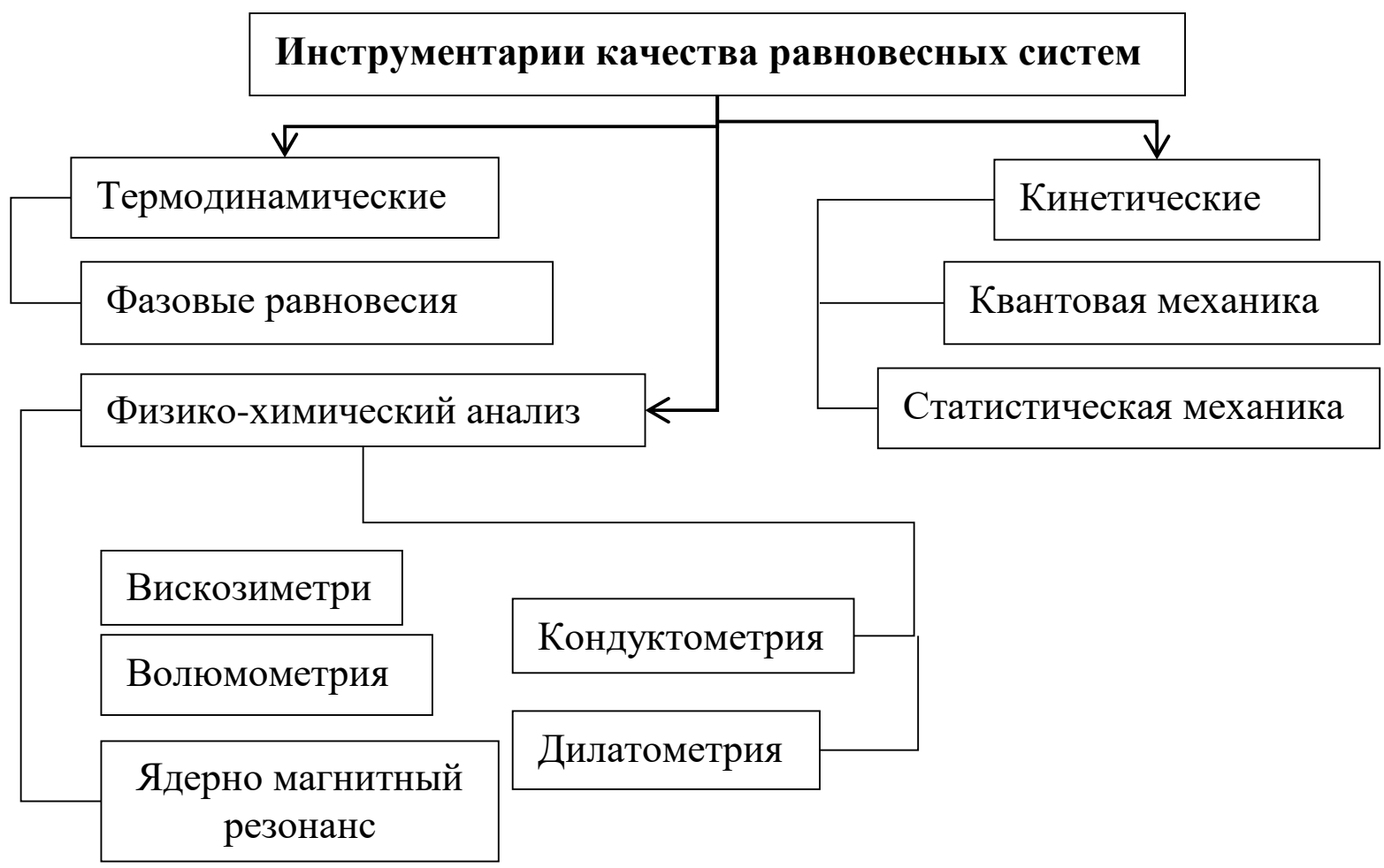

Рис. 2.2. Схема инструментариев качества равновесных систем

Динамическое состояние системы микрочастиц (электронов, ионов, атомов, молекул) описывается совокупностью квантовых чисел с помощью законов волновой механики. Особенности движения микрочастиц и их активацию во времени исследуются кинетическими методами. Физикохимический анализ позволяет судить о взаимодействии веществ по зависимости термодинамических свойств равновесных систем (температуры, объема, давления, плотности, вязкости и других) от состава. Методы физикохимического анализа: термический, микроструктурный, рентгенографический, кондуктометрия, дилатометрия, вискозиметрия описывают состояние равновесной системы по изменению термодинамических функций. Молекулярная спектроскопия, электроскопия, радиоспектроскопия, ядерномагнитный резонанс (ЯМР) позволяют объяснить строение молекул за счет 45 


\section{СТАБИЛИЗАЦИЯ СВОЙСТВ ТОПЛИВНО-ЭНЕРГЕТИЧЕСКИХ СИСТЕМ НА ОСНОВЕ ПРИРОДНЫХ И СИНТЕТИЧЕСКИХ ПОЛИМЕРОВ}

изменения внутримолекулярных сил, связывающих атомы в молекулу, рассчитать термодинамические свойства, моделировать механизм химических реакций. Исследование фазовых равновесий многокомпонентных систем основано на анализе геометрического облика диаграмм фазовых равновесий, построенных в виде равностороннего концентрационного треугольника ГиббсаРозебома (рис.2.3).

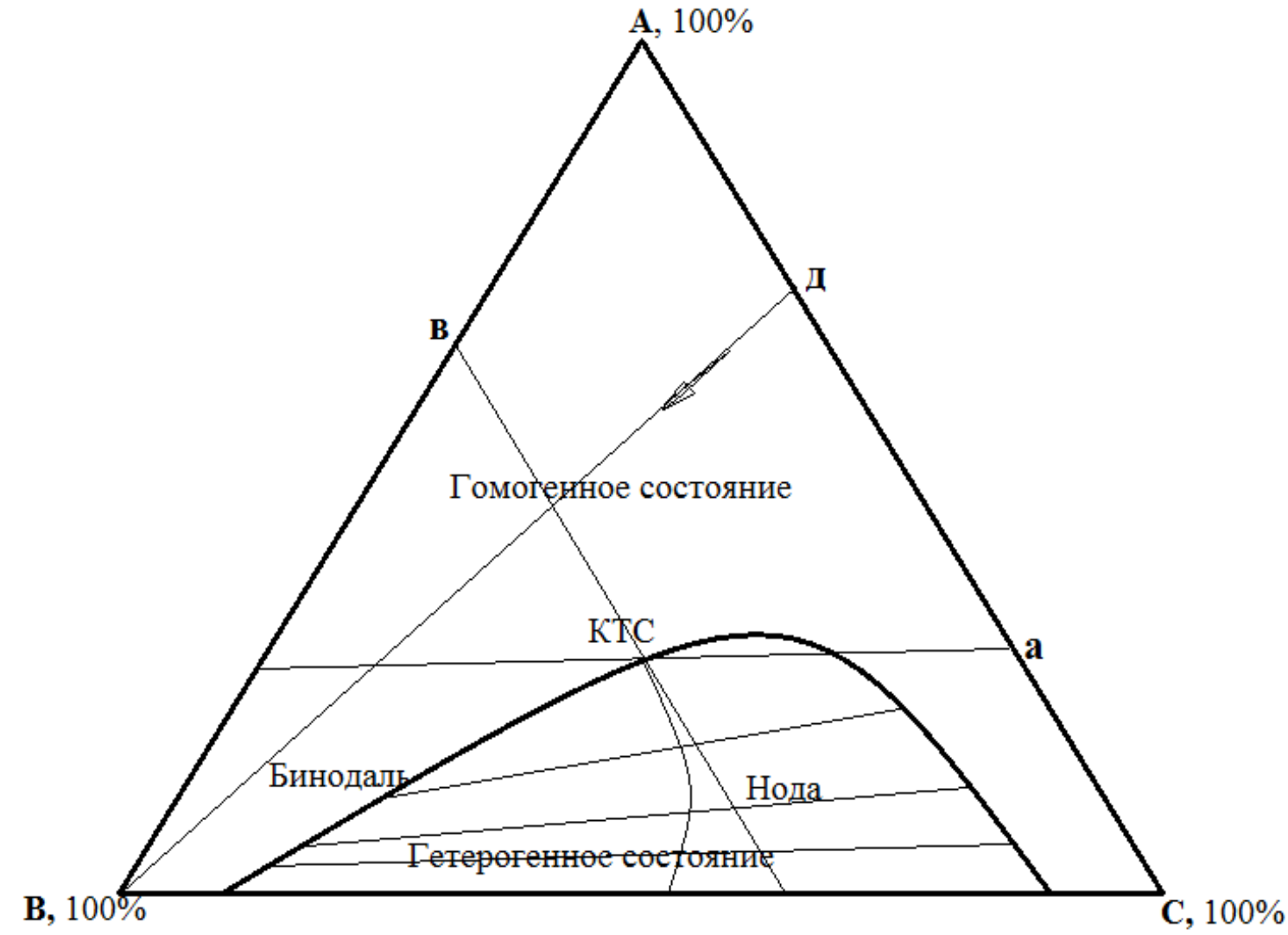

Рис. 2.3. Геометрический облик диаграммы фазовых равновесий в модельной трехкомпонентной системе А - В - C

Основные геометрические элементы модельной системы $\mathrm{B}-\mathrm{A}-\mathrm{C}$, используемые для анализа диаграмм состояния, это - вершина треугольника, сторона, луч, критическая точка, нода, бинодаль, область состояния. Вершины треугольника соответствуют содержанию чистых компонентов A, B, С. Каждая сторона характеризует состояние и состав бинарных систем $\mathrm{B}-\mathrm{C}, \mathrm{B}-\mathrm{A}, \mathrm{A}-\mathrm{C}$. 


\section{СТАБИЛИЗАЦИЯ СВОЙСТВ ТОПЛИВНО-ЭНЕРГЕТИЧЕСКИХ СИСТЕМ НА ОСНОВЕ ПРИРОДНЫХ И СИНТЕТИЧЕСКИХ ПОЛИМЕРОВ}

Бинарные системы В - A и А - C находятся в стабильном, гомогенном состоянии при любых соотношениях чистых компонентов.

Компоненты бинарной системы В - С ограниченно растворяются друг в друге. Полная взаимная совместимость в системе происходит при нижней критической температуре смешения (НКТС) или верхней критической температуре смешения (ВКТС). На диаграмме состояния бинарных гетерогенных систем бинодальная кривая имеет максимум - ВКТС или минимум - НКТС. Замкнутая бинодальная кривая имеет одновременно максимум и минимум. Бинодаль делит площадь треугольника на две части: гомогенную и гетерогенную. Гетерогенная область примыкает к стороне бинарной системы B-C. При введении в эту систему третьего компонента A происходит увеличение взаимной растворимости компонентов В и С до полной гомогенизации. Бинодальная кривая ассиметрична - левая ветвь длиннее правой, и вытянута в сторону $\mathrm{A}-\mathrm{C}$, имеет максимум, который не совпадает с критической точкой. За пределами критической точки тройная система $\mathrm{B}-\mathrm{A}-\mathrm{C}$ находится в гомогенном, стабильном состоянии. Ноды расходятся в сторону $\mathrm{A}-\mathrm{C}$, линия, проведенная через их середины, представляет собой кривую. Эти признаки свидетельствуют о преобладающем взаимодействии компонентов А и С в тройной системе. Состав критической точки находится по правилу Алексеева. На параллельных линиях содержание компонентов $\mathrm{A}=$ const, a соотношение $\mathrm{C}$ : В изменяется; или $\mathrm{B}=$ const, a соотношение $\mathrm{A}: \mathrm{C}$ изменяется. На лучах треугольника соотношение двух компонентов А : С постоянно, а содержание третьего компонента В изменяется от 0 \% до 100 \%. Распределение третьего вещества А между двумя жидкими фазами в состояние равновесия подчиняется законом распределения

$$
\mathrm{K}=\frac{\mathrm{C}_{1}^{\mathrm{A}}}{\mathrm{C}_{2}^{\mathrm{A}}}=\text { konst, }
$$

где $\mathrm{C}_{1}^{\mathrm{A}}$ - насыщенный раствор гомогенизатора А в растворителе 1 (фаза 1); $\mathrm{C}_{2}^{\mathrm{A}}$ - насыщенный раствор гомогенизатора А в растворителе 2 (фаза 2); К - коэффициент распределения (экстракции). 


\subsection{1 Особенности межмолекулярных взаимодействий}

низкомолекулярных компонентов

Характер межмолекулярных взаимодействий во многом определяется структурой и свойствами индивидуальных веществ и, в первую очередь, воды, молекулы которой при самопроизвольном взаимодействии образуют циклические ассоциаты за счет водородных связей (рис.2.4), полости которых частично заполнены мономерными (тетраэдрическими) молекулами. По мере заполнения полостей образуется равновесная смесь ассоциатов с менее плотной $\left(\mathrm{H}_{2} \mathrm{O}\right)_{\mathrm{L}}$ и более плотной $\left(\mathrm{H}_{2} \mathrm{O}\right)_{\mathrm{H}}$ упаковкой тетраэдрических молекул: $\left(\mathrm{H}_{2} \mathrm{O}\right)_{\mathrm{L}} \leftrightarrow\left(\mathrm{H}_{2} \mathrm{O}\right)_{\text {H }}$ [31]. Создаются предпосылки для образования более сложных стабильных структур типа жидких кристаллов (клатратов или кластеров) $[34,35]$.

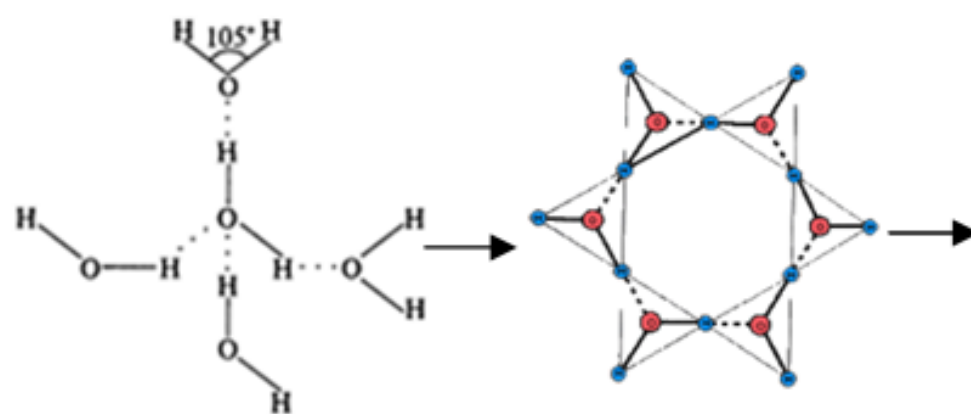

Тетраэдрическая

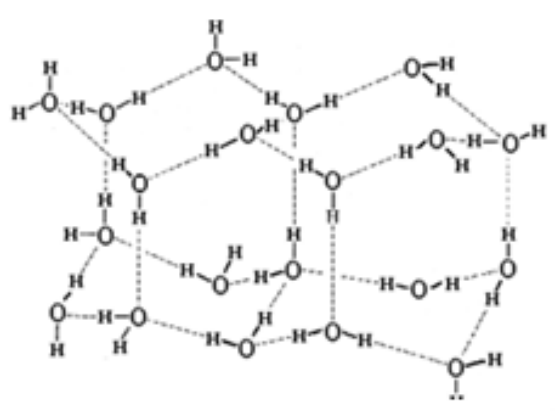

Клатратная

\section{Рис. 2.4. Схема образования циклических структур}

Стабилизация кластеров в приповерхностном слое воды связана с высокой структурной упорядоченностью слоя. При удалении от поверхности раздела упорядоченных слоев вглубь жидкости степень упорядоченности понижается. При некотором расстоянии от поверхности упорядоченность свободных молекул соответствует состоянию жидкости в объемной фазе [37]. Образование квазиклатратных водных структурных элементов вокруг 
растворенных в ней молекул неэлектролита стабилизирует свойства бинарных систем вода-полярный органический растворитель (этилцеллозольв, бутилцеллозольв) [38].

В клатратной модели из ассоциатов-пентамеров $\left(\mathrm{H}_{2} \mathrm{O}\right)_{5}$, образуется конфигурация правильного додекаэдра водного кластера с «мерцающей» структурой из 20 молекулы воды и больше (рис. 2.5), что можно обнаружить методом ЯМР.

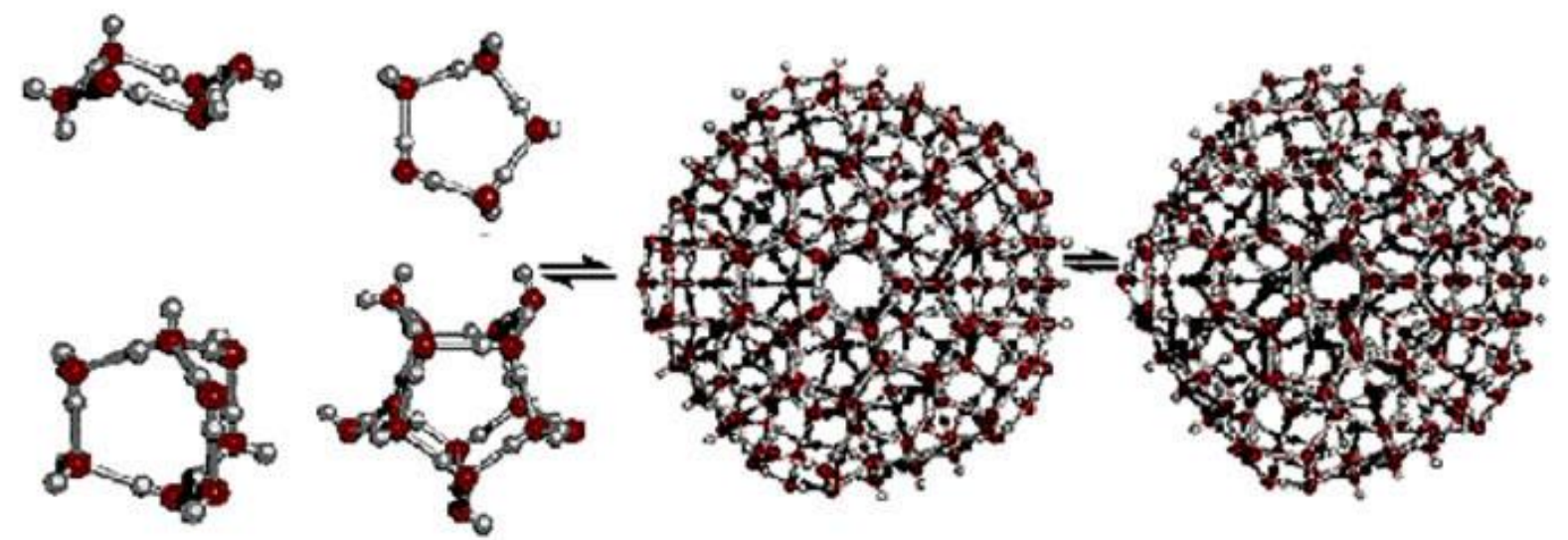

Рис. 2.5. Схема образования полимерных кластеров воды

Гетерофазные кластеры воды размером 3,5.. 30 мкм могут содержать в своей структуре как ассоциированные молекулы воды, так и фрагменты, обладающие развитой или сильно выраженной ближней упорядоченной структурой $[34,35]$.

Механизм растворения низкомолекулярных органических веществ в воде включает образование полостей с последующим размещением растворяемой частицы в полости с учетом ближних и дальних сил межмолекулярных взаимодействий с окружающими молекулами растворителя и собственного объема для размещения в свободном пространстве растворителя. В области критических точек размеры молекулы неэлектролита становятся несоизмеримыми с размерами кластеров воды и неспособны проникать внутрь их. Это связано с межмолекулярным взаимодействием молекул неэлектролитов на границе неупорядоченной зоны кластеров со свободными молекулами воды 
и образованием водородных связей. Молекулы растворителя находятся между кластерами чистой воды. Происходит пространственное разделение мест локализации молекул воды и неэлектролита, и система переходит в метастабильное микрогетерогенное состояние. При этом возрастает вероятность образования за счет тепловых флуктуаций полимерных упорядоченных межмолекулярных кластеров в виде глобул, что обеспечивает медленное расслаивание (опалесценсия) [38]. При соизмеримости геометрических параметров низкомолекулярных органических веществ с размерами кластеров воды происходит их внедрение в пустоты и стабилизация структуры воды.

Структура и свойства молекул аминов, используемых для увеличения растворимости синтетических полимеров в смешанных водно-органических растворителях, имеют сходство со структурой и свойствами молекулы аммиака, в которой один (первичный $\mathrm{R}^{1}-\mathrm{NH}_{2}$ ), два (вторичный $\mathrm{R}^{1}-\mathrm{NH}_{2}-\mathrm{R}^{2}$ ) или три атома водорода (третичный) замещены на углеводородные радикалы. Молекулы аминов способны к образованию более сильной донорноакцепторной связи. Протон $\mathrm{H}^{+}$, являясь акцептором электронов, образует ковалентную связь $\mathrm{N}-\mathrm{H}$ в ионе $\mathrm{R}_{3} \mathrm{NH}^{+}$(рис.2.6). Причем электронно-донорная способность аминов более выражена, чем электронно-акцепторная. Поэтому молекулы аминов слабо ассоциированы и хорошо растворяются в воде. Проявляют ярко выраженные свойства оснований. Энергия Н-связи между алифатическими аминами и водой составляет $23,8-24,7$ кДж•моль ${ }^{-1}$.

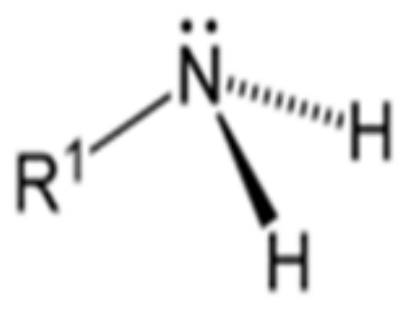

Первичный

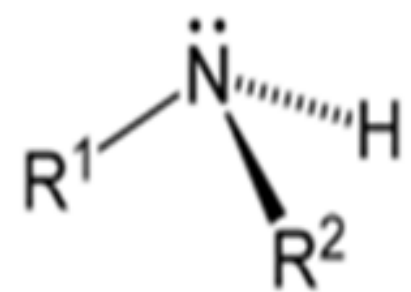

Вторичный

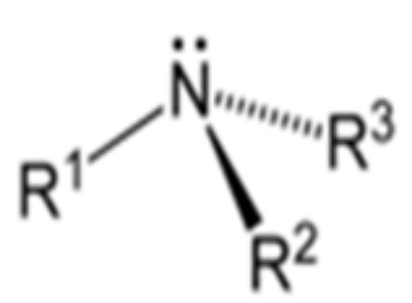

Третичный амин

\section{Рис. 2.6. Структура аминов}




\section{СТАБИЛИЗАЦИЯ СВОЙСТВ ТОПЛИВНО-ЭНЕРГЕТИЧЕСКИХ СИСТЕМ НА ОСНОВЕ ПРИРОДНЫХ И СИНТЕТИЧЕСКИХ ПОЛИМЕРОВ}

При взаимодействии алифатических аминов с водой образуются гидроксиды алкиламмония (реакция 1), а при взаимодействии с кислотами (HAn) - алкиламмониевые соли (реакция 2), растворимые в воде:

$$
\begin{gathered}
\mathrm{CH}_{3} \mathrm{NH}_{2}+\mathrm{HOH} \leftrightarrow\left[\mathrm{CH}_{3} \mathrm{NH}_{3}\right] \mathrm{OH} \\
\mathrm{CH}_{3} \mathrm{NH}_{2}+\mathrm{HAn} \leftrightarrow\left[\mathrm{CH}_{3} \mathrm{NH}_{3}\right] \mathrm{A}_{\mathrm{n}}+\mathrm{H}^{+}
\end{gathered}
$$

В области низких концентраций амина (<0,4 молей) образуются гидраты за счет образования двух типов Н-связей: Н... N и Н...О [39]. Из-за отсутствия свободного атома водорода в молекуле триэтиламина (ТЭА), взаимодействие с водой происходит только за счет связи N...H (рис.2.7). Образование гидратов триэтиламина данного состава за счет связей N...H возможно только при температуре ниже критической (табл.2.1), так как с повышением температуры уменьшаются силы взаимодействия молекул ТЭА с молекулами воды и происходит уменьшение их взаимной растворимости.

a

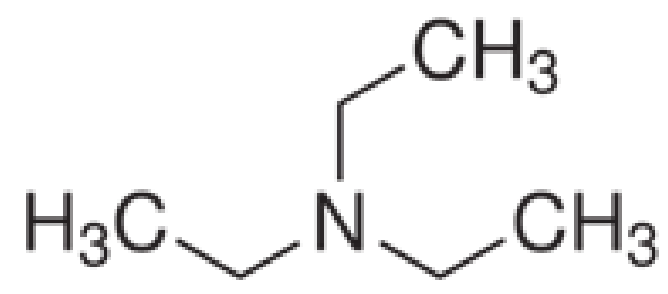

6

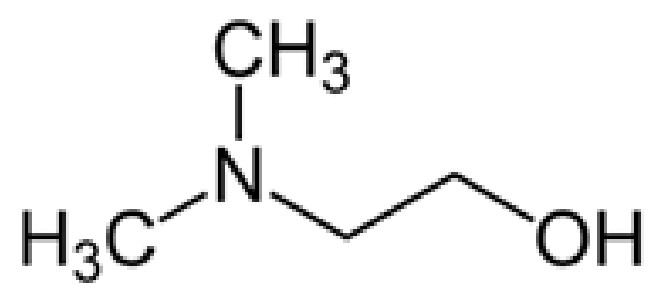

Рис. 2.7. Структурные формулы: а) триэтиламина и б)диметилэтаноламина

Таблица 2.1

Критические температуры смешения в бинарных системах

\begin{tabular}{|l|c|c|}
\hline \multirow{2}{*}{ Бинарные системы } & \multicolumn{2}{|c|}{ Критические температуры смешения, ${ }^{0} \mathrm{C}$} \\
\cline { 1 - 3 } & Нижняя, НКТС & Верхняя, ВКТС \\
\hline Вода-диэтиламин & 140 & - \\
\hline Вода-триэтиламин & 18,6 & - \\
\hline Вода-бутилцеллозольв & 49,1 & 128 \\
\hline вода-н-бутанол & - & 290.05 \\
\hline
\end{tabular}




\section{СТАБИЛИЗАЦИЯ СВОЙСТВ ТОПЛИВНО-ЭНЕРГЕТИЧЕСКИХ СИСТЕМ НА ОСНОВЕ ПРИРОДНЫХ И СИНТЕТИЧЕСКИХ ПОЛИМЕРОВ}

C увеличением числа, и размера углеводородного радикала (R) в молекуле амина ослабевает электронно-донорная способность аминов и их растворимость в воде, которая во многом определяется энтропийным $\left(\mathrm{TS}^{\mathrm{E}}\right)$ и энтальпийным $\left(\mathrm{H}^{\mathrm{E}}\right)$ факторами [31, 40, 41, 42]. При смешении аминов (ДЭА, ТЭА) с водой обнаружен минимум значений избыточной энтальпии $\left(\mathrm{H}^{\mathrm{E}}\right)$, лежащий в средней области концентрационного интервала, что свидетельствует об экзотермическом эффекте смешения. Сходные концентрационные зависимости (одинаковая форма кривых) обнаружены и для других термодинамических функций $\left(\mathrm{G}^{\mathrm{E}}\right.$ и $\left.\mathrm{TS}^{\mathrm{E}}\right)$. При концентрациях амина $\mathrm{X}_{\mathrm{RNH}_{2}} \leq 1,5 \%$ (моль.) объемная структура воды не нарушена. При $\mathrm{X}_{\mathrm{RNH}_{2}} \approx 0,45 \%$ (моль.) происходит деформация и перестройка структуры воды с образованием смешанных ассоциатов по типу замещения. Образование межмолекулярных комплексов вода:амин $=1: 2$ и 1:1 подтверждается и при изучении ИК-спектров системы вода-триэтиламин. При этом приблизительно $30 \%$ молекул воды входит в состав комплексов $1: 1$ и $70 \%$ - в состав комплексов 1:2. При уменьшении содержания амина происходит уменьшение содержания комплексов 1:2 и возрастает число комплексов 1:1. Энергия $-\mathrm{H}$ связи в этих комплексах составила 21,3 кДж·моль ${ }^{-1}$. Тепловые эффекты образования комплексов 17,6 и 6,7 кДж·моль ${ }^{-1}$ [37-42].

\section{2 Отражение межмолекулярных взаимодействий низкомолекулярных} компонентов на стабильность пленкообразующих систем

\subsection{1 Физико-химический анализ летучей части пленкообразующих систем}

В связи с тем, что формирование покрытия ЛКМ происходит в температурном режиме $\left(130 \ldots 150^{\circ} \mathrm{C}\right)$ испарения низкомолекулярных компонентов раствора ПОС, дальнейшие исследования по проверке гипотезы: 


\section{СТАБИЛИЗАЦИЯ СВОЙСТВ ТОПЛИВНО-ЭНЕРГЕТИЧЕСКИХ СИСТЕМ НА ОСНОВЕ ПРИРОДНЫХ И СИНТЕТИЧЕСКИХ ПОЛИМЕРОВ}

отражения межмолекулярных взаимодействий низкомолекулярных

компонентов на стабильность пленкообразующих систем проводились с помощью инструментариев физико-химического анализа в диапазоне температур $25^{0} \ldots 75^{\circ} \mathrm{C}$ и области составов $0 \ldots 100 \%$. При этих условиях исследовали геометрический облик кривых свойств $\mathrm{Y}(\rho, \eta, \mathrm{V})=f($ состава) и кривых избыточных функций $\mathrm{Y}^{\mathrm{E}}\left(\rho^{\mathrm{E}}, \eta^{\mathrm{E}}, \mathrm{V}^{\mathrm{E}}\right)=f$ (состава) широкого спектра бинарных и тройных низкомолекулярных систем, в составе которых использовали воду, амины: вторичный - диэтиламин (ДЭА), третичный триэтиламин (ТЭА) и аминоспирт - диметилэтаноламин (ДМЭА); полярные органические растворители: н- алифатический спирт бутанол (н-Б), содержащий полярную гидроксильную группу (-OH), эфиры: бутилацетат (БАЦ), содержащий простую эфирную связь (-О-), этилцеллозольв (ЭЦ), бутилцеллозольв (БЦ), которые являясь эфирами этиленгликоля, содержат как -ОН группы, так и эфирную связь (-O-).

Наиболее ярко межмолекулярные взаимодействия отразились на геометрическом облике кривых свойств $\eta=f$ (состава) в системах Вода-ДЭА (ДМЭА) (рис.2.8) или Вода - БЦ (ЭЦ) (рис.2.9), имеющих ярко выраженные максимумы при $25^{\circ} \mathrm{C}$, что свидетельствует о сильном взаимодействии аминов и целлозольвов с водой за счет образования водородных связей. В системе Вода - ДЭА максимум находится в области высоких концентраций воды, а в системе вода - ДМЭА - в области средних концентраций воды и ДМЭА. С повышением температуры максимум становится размытым, а положение максимума на кривых свойства не меняется. Высота максимума в системе вода - ДЭА меньше примерно в два раза, чем в системе вода - ДМЭА [43- 45]. 

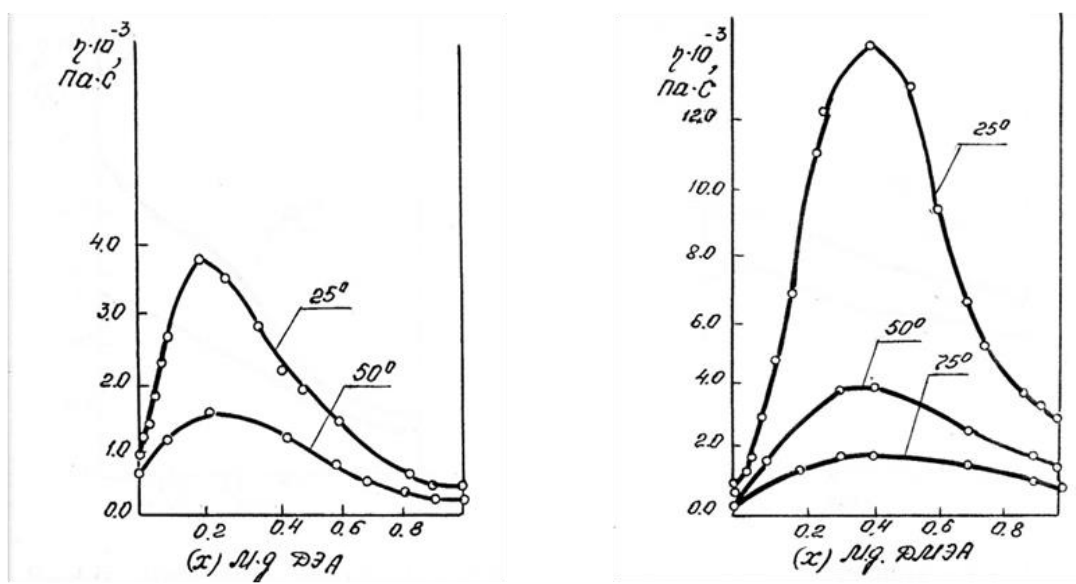

Рис. 2.8. Изменение вязкости при температурах $25,50,75^{\circ} \mathrm{C}$ в системах:

а) Вода - ДЭА; б) Вода - ДМЭА

В системах вода - БЦ (ЭЦ) (рис. 2.9) максимум смещен в область высоких концентраций воды. Смешение аминов с полярными органическими растворителями: БЦ, ЭЦ, н-Б, БАЦ, сопровождается более слабыми межмолекулярными взаимодействиями, чем при смешении аминов с водой, которое отражается на характере кривых свойств. В системах ДМЭА-БЦ или ДМЭА-ЭЦ (рис. 2.10) присутствуют точки перегиба на S-образных изотермах. Аналогичный характер изотерм вязкости обнаружен и в системах ДЭА (ТЭА) - н-Б при $25^{\circ} \mathrm{C}$.
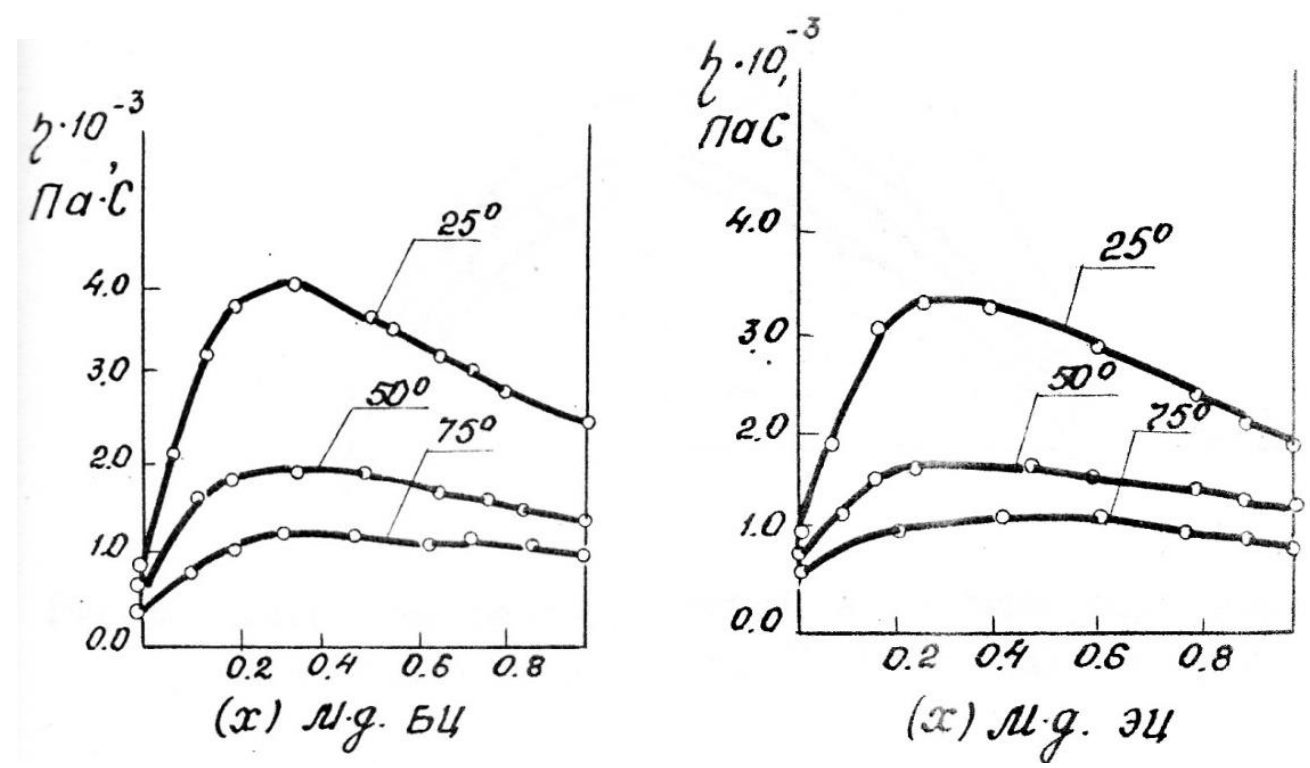

Рис. 2.9. Изменение вязкости при температурах $25,50,75^{\circ} \mathrm{C}$ в системах:

а) вода - БЦ; б) вода - ЭЦ 
Повышение температуры до $50 . .75^{\circ} \mathrm{C}$ отражается на геометрическом облике кривых - свойств: S-образные кривые от оси состава стремятся к монотонно выпуклым. Это связано с разрушением более слабой водородной связи Н...О в межмолекулярных соединениях и отражается в исчезновении точки перегиба.
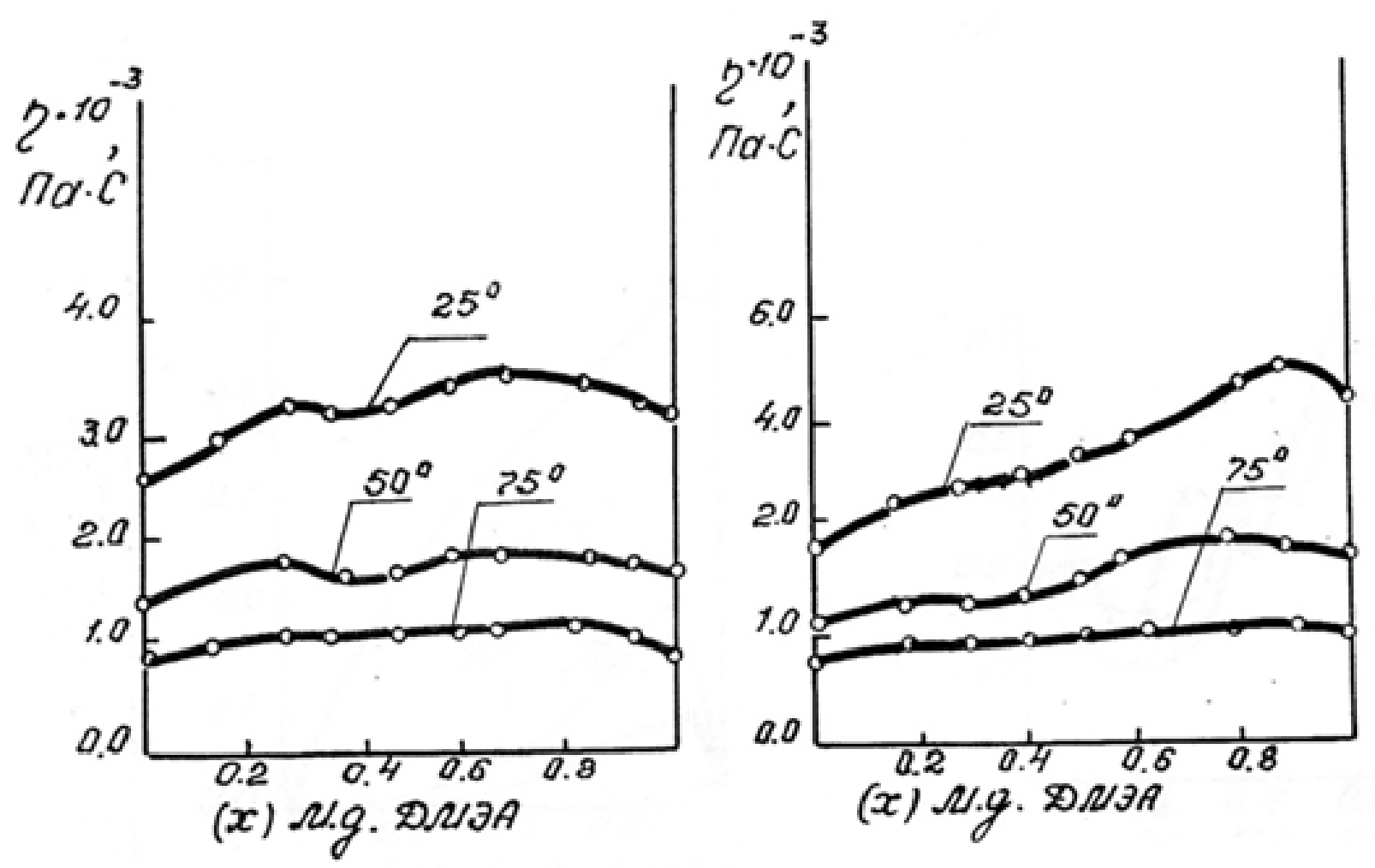

Рис. 2.10. Изотермы вязкости при температуре $25,5^{\circ}, 7^{\circ} \mathrm{C}$ в системах:

$$
\text { а) БЦ - ДМЭА; б) ЭЦ - ДМЭА }
$$

Изотермы вязкости в бинарных гомогенных системах Амин - БАЦ монотонно выпуклы от оси состава, что свидетельствует о слабом межмолекулярном взаимодействии между компонентами системы. Полученные данные коррелируют с данными ЯМР исследований (рис.2.11) [46]. 

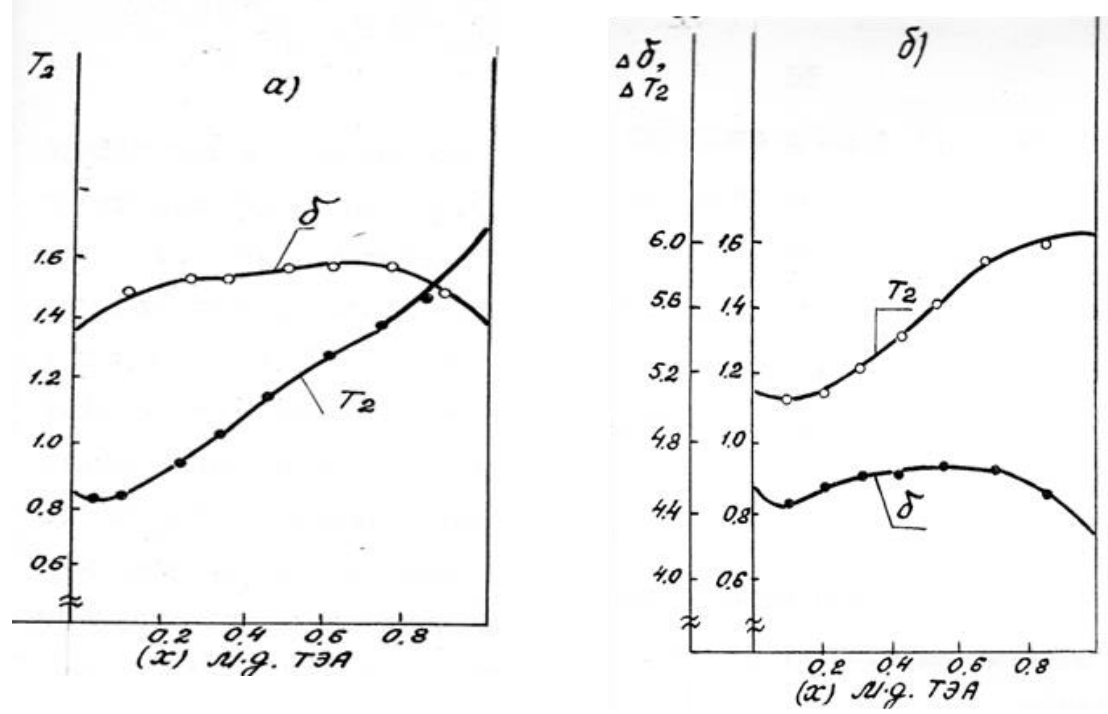

\section{Рис. 2.11. Изменения химического сдвига (ס), времени релаксации $\left(\mathrm{T}_{2}\right)$ и} отклонений $\Delta \delta$ и $\Delta T_{2}$ от состава в системах: а) БЦ-ТЭА; б)ЭЦ-ТЭА

Состав образующихся межмолекулярных соединений в гомогенных бинарных системах вода - амин, вода - полярный органический растворитель (ПОР), вода - целлозольв определялся по положению максимума на кривых избыточных функций $\mathrm{Y}^{\mathrm{E}}\left(\rho^{\mathrm{E}}, \eta^{\mathrm{E}},\right)=f\left(\right.$ состава) или минимума кривых $\Delta \mathrm{V}\left(\mathrm{V}^{\mathrm{E}}\right)=f$ (состава). При взаимодействии ДЭА с водой образуются комплексы состава вода:ДЭА=2:1 (рис. 2.12а) и вода:ДЭА=1:1 (рис.2.12б) устойчивые в интервале температур $25 \ldots 50^{\circ} \mathrm{C}$.

Взаимодействие воды с диметилэтаноламином протекает с образованием сольватных $\quad$ комплексов $\quad$ вода:ДМЭА=1:1 (рис.2.13), вода:ДМЭА=2:1 и вода:ДМЭА=1:9. Образование аминогидратов при мольном соотношении $\mathrm{H}_{2} \mathrm{O}:$ ДМЭА $=2: 1$ (1:1) согласуется с данными [31, 41]. Энергия водородной связи в этих комплексах составила 21,3 кДж·моль-1. Тепловые эффекты образования комплексов 17,6 и 6,7 кДж·мол. 

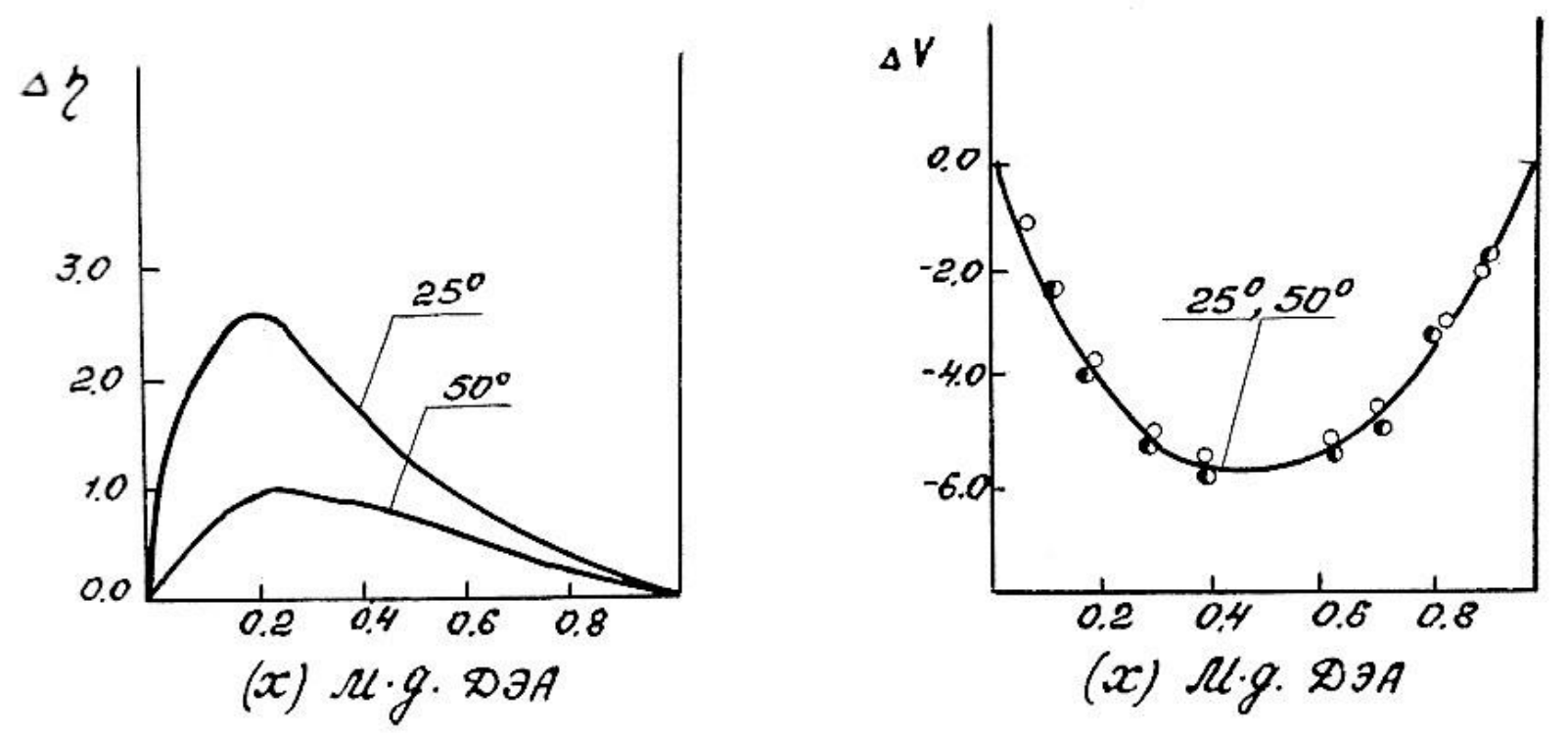

Рис. 2.12. Зависимость отклонений вязкости $\Delta \eta$ (а) и мольного объема $\Delta \mathrm{V}$ (б) от состава в системе вода - диэтиламин (ДЭА) при температурах $25,5^{\circ} \mathrm{C}$

a)

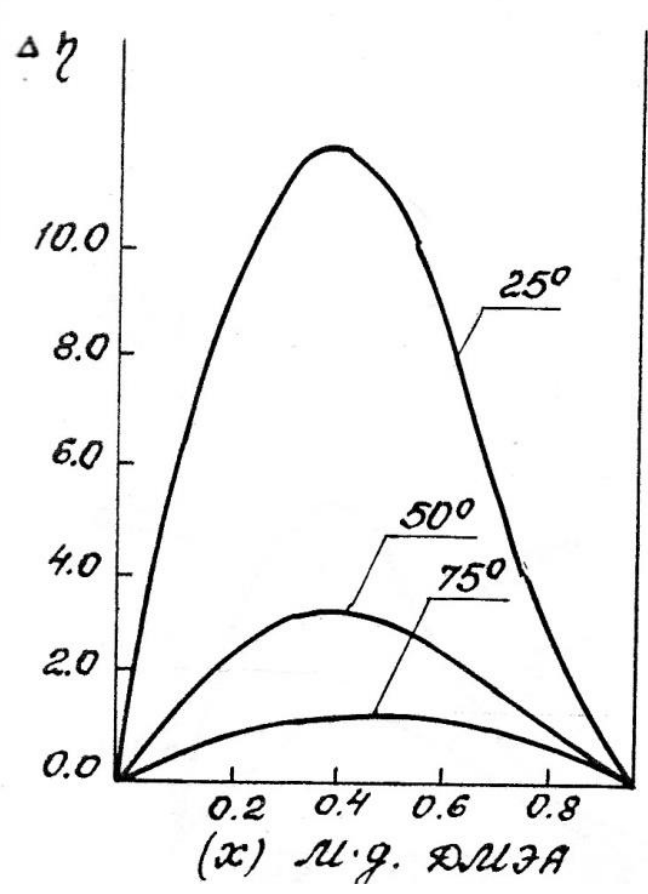

б)

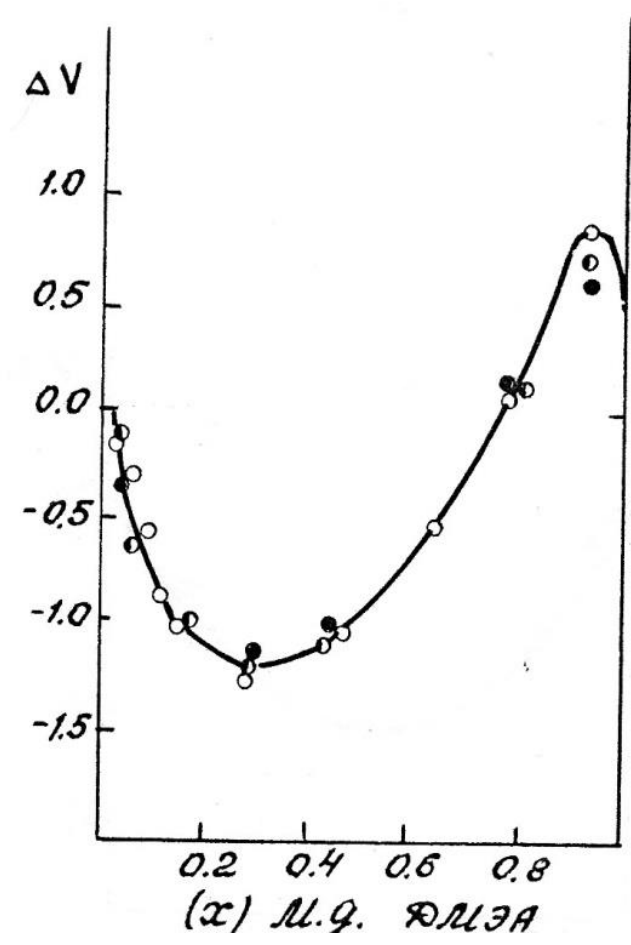

Рис. 2.13. Изотермы отклонений вязкости $\Delta \eta$ (а) и мольного объема $\Delta V$ (б) в системе вода - диметилэтаноламин (ДМЭА) при температурах $25,50,7^{\circ} \mathrm{C}$ 


\section{СТАБИЛИЗАЦИЯ СВОЙСТВ ТОПЛИВНО-ЭНЕРГЕТИЧЕСКИХ СИСТЕМ НА ОСНОВЕ ПРИРОДНЫХ И СИНТЕТИЧЕСКИХ ПОЛИМЕРОВ}

Взаимодействие ДМЭА с водой преобладает по силе взаимодействие ДЭА с водой за счет изменения соотношения донорно-акцепторных сил. В этой же последовательности уменьшается растворимость данных аминов в воде. Система Вода - ДМЭА гомогенная во всем диапазоне концентраций $0 \ldots 100 \%$ и температур $25 \ldots 75^{\circ} \mathrm{C}$, система Вода - ДЭА расслаивается при температуре $140^{\circ} \mathrm{C}$, а система Вода - ТЭА при температуре $18,6^{\circ} \mathrm{C}$.

C увеличением числа, и размера углеводородного радикала (R) в молекуле амина ослабевает электронно-донорная способность аминов и их растворимость в воде. В структуре молекулы ДМЭА кроме двух гидрофобных радикалов $\mathrm{CH}_{3}$ и свободных атомов водорода, имеется полярная гидроксильная группа (-OH), которая также может образовывать два типа водородных связей Н...N и Н...О. Этим можно объяснить образование комплекса $\mathrm{H}_{2} \mathrm{O}:$ ДМЭА $=1: 9$. Энергия Н-связи между алифатическими аминами и водой составляет 23,8 ..24,7 кДж·моль ${ }^{-1}$, что превышает примерно на 6 кДж·моль ${ }^{-1}$ энергии Н-связи спирт-вода. Более сильная Н-связь аминов с водой обуславливает их растворимость в воде.

В системах Амин - полярный органический растворитель (ЭЦ, БЦ, н-Б, БАЦ) максимальное отклонение на изотермах отклонений вязкости и мольного объема примерно в $5 \ldots 10$ раз меньше, чем в системах вода - амин. Устойчивость межмолекулярных комплексов определяется структурой амина. При анализе избыточных кривых вязкости и мольного объема в системах с вторичным амином ДЭА - БЦ (рис. 2.14) или ДЭА - н-Б (рис. 2.15) имеются ярко выраженный максимум (рис.2.14a, 2.15a) и минимум (рис. 2.14 б, 2.15 б), которые отвечают составам комплексов ДЭА•БЦ и ДЭА•н-Б или ДЭА•ЗБЦ и ДЭА•ЗН-Б устойчивых в диапазоне температур $25 \ldots 50^{\circ} \mathrm{C}$.

В системах с третичным амином на изотермах избыточных функций: вязкости $\Delta \eta\left(\eta^{\mathrm{E}}\right)=f$ (состава) или мольного объема $\Delta \mathrm{V}\left(\mathrm{V}^{\mathrm{E}}\right)=f$ (состава) 
имеются несколько экстремальных точек. На изотермах избыточной вязкости в системе ТЭА - БЦ имеется максимум, приходящийся на состав комплекса ТЭА•2БЦ и минимум, приходящийся на состав соединения БЦ•9ТЭА (рис. 2.16а). При мольном соотношении ТЭА:БЦ равном $1: 1$ на кривой $\Delta \eta\left(\eta^{\mathrm{E}}\right)=f$ (состава) имеется точка перегиба, а на изотерме $\Delta \mathrm{V}\left(\mathrm{V}^{\mathrm{E}}\right)=f$ (состава) при этом соотношении компонентов обнаружен максимум (рис. 2.16 б).

Можно предположить, что при взаимодействии ТЭА с БЦ в области средних концентраций происходит перестройка структуры комплекса ТЭА•2БЦ с образованием промежуточного активного комплекса БЦ•ТЭА, который при дальнейшем повышении концентрации ТЭА разрушается с образованием соединения БЦ•9ТЭА.
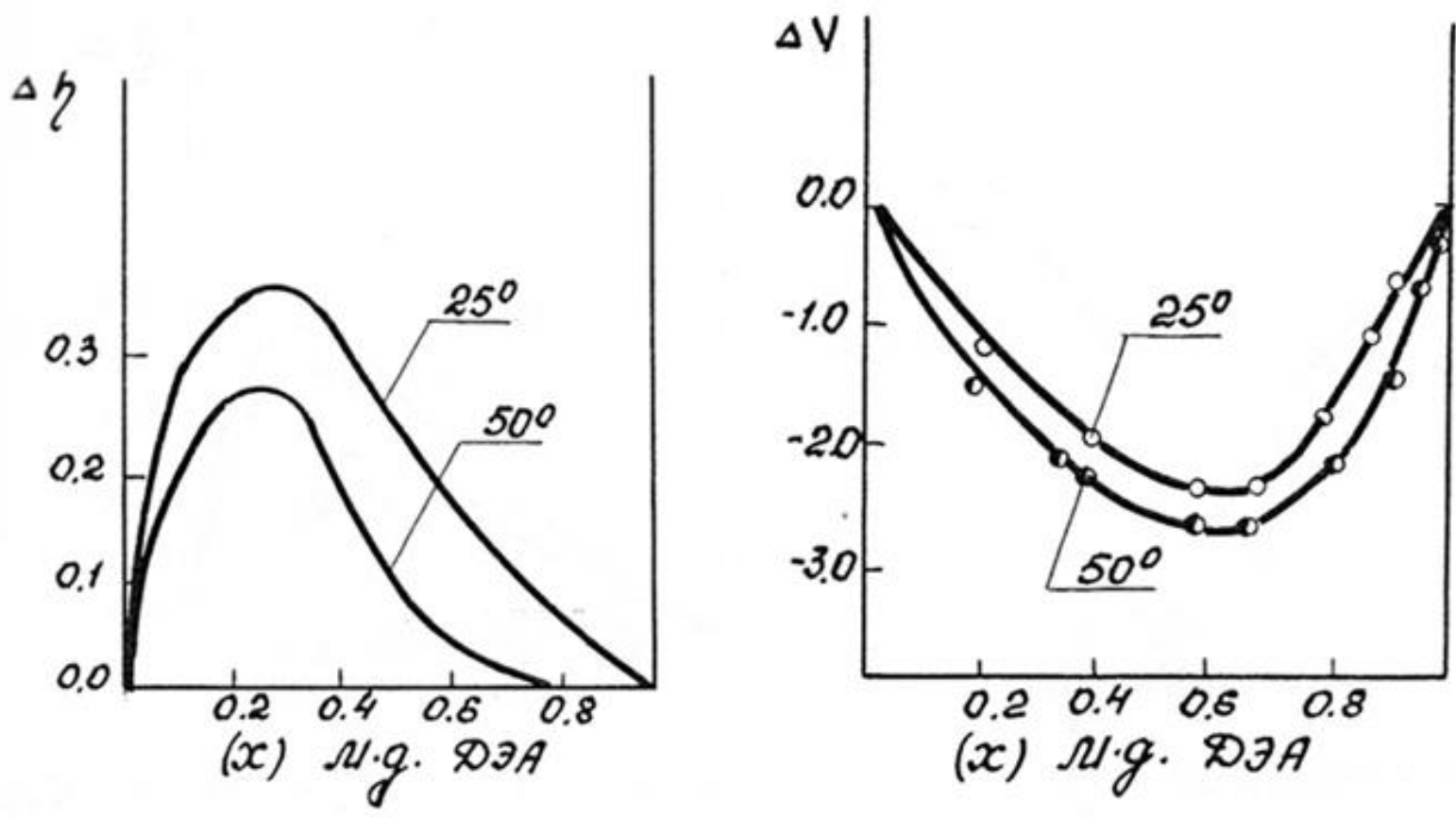

Рис. 2.14. Изотермы отклонений вязкости $\Delta \eta$ (а) и мольного объема $\Delta V$ (б) в системе ДЭА - БЦ при температурах $25,50^{\circ} \mathrm{C}$ 

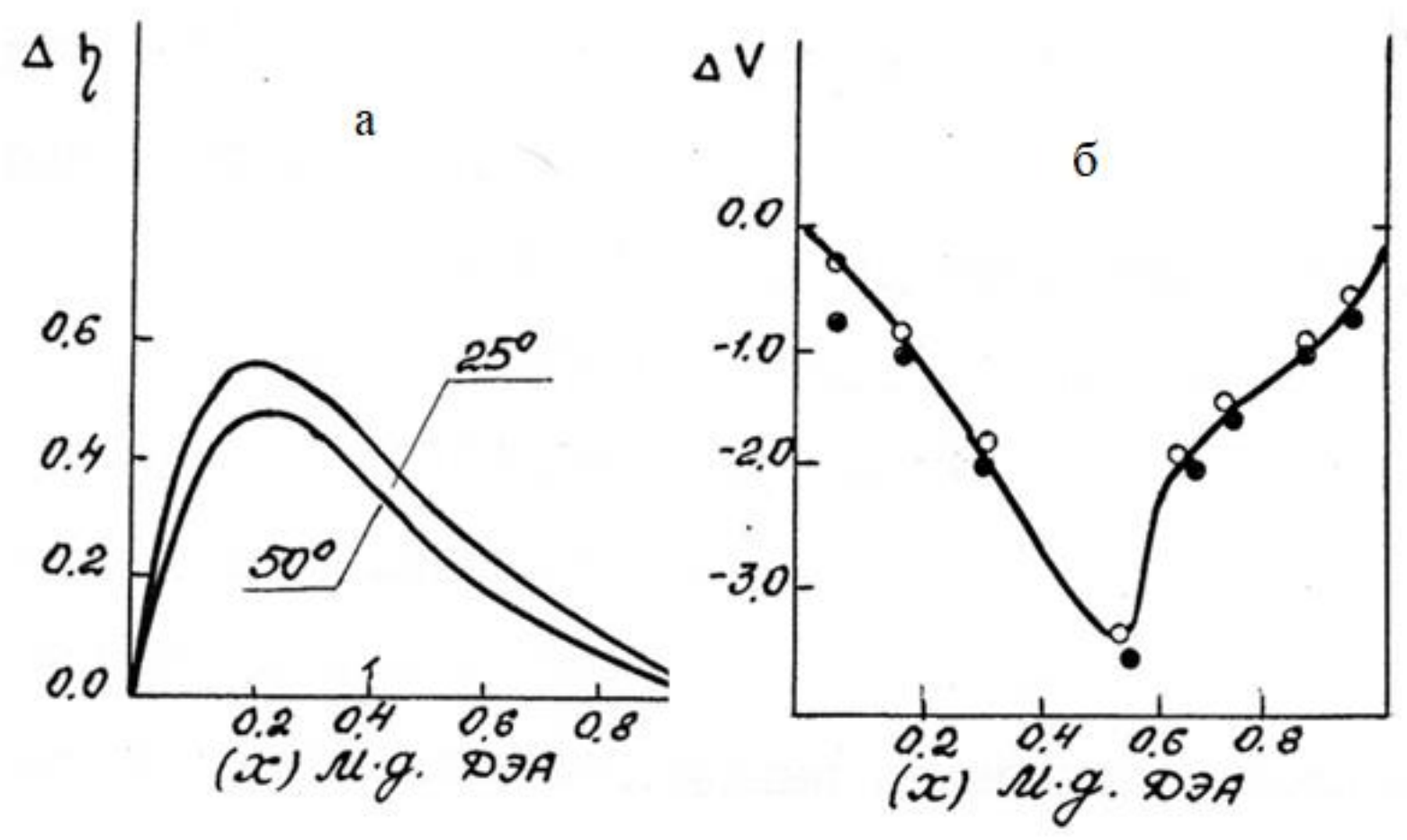

Рис. 2.15. Изотермы отклонений вязкости $\Delta \eta$ (а) и мольного объема $\Delta \mathrm{V}$ (б) в системе ДЭА - н-Бутанол при температурах $25,50^{\circ} \mathrm{C}$

Более слабое взаимодействие ТЭА с БЦ или н-Б по-видимому связано со стерическим фактором, с образованием менее прочной водородной связи Н...О. Аналогичная зависимость избыточных функций обнаружена и в системах ТЭА - ЭЦ (БАЦ). В системах ДМЭА - полярный органический растворитель отклонения мольного объема положительны, что свидетельствует о преобладании внутримолекулярных сил диметилэтаноламина (ДМЭА-ДМЭА) или бутилцеллозольва (БЦ-БЦ) по сравнению с межмолекулярными силами в комплексах переменного состава (ДМЭА•БЦ, ЗДМЭА•БЦ, 9ДМЭА•БЦ). 

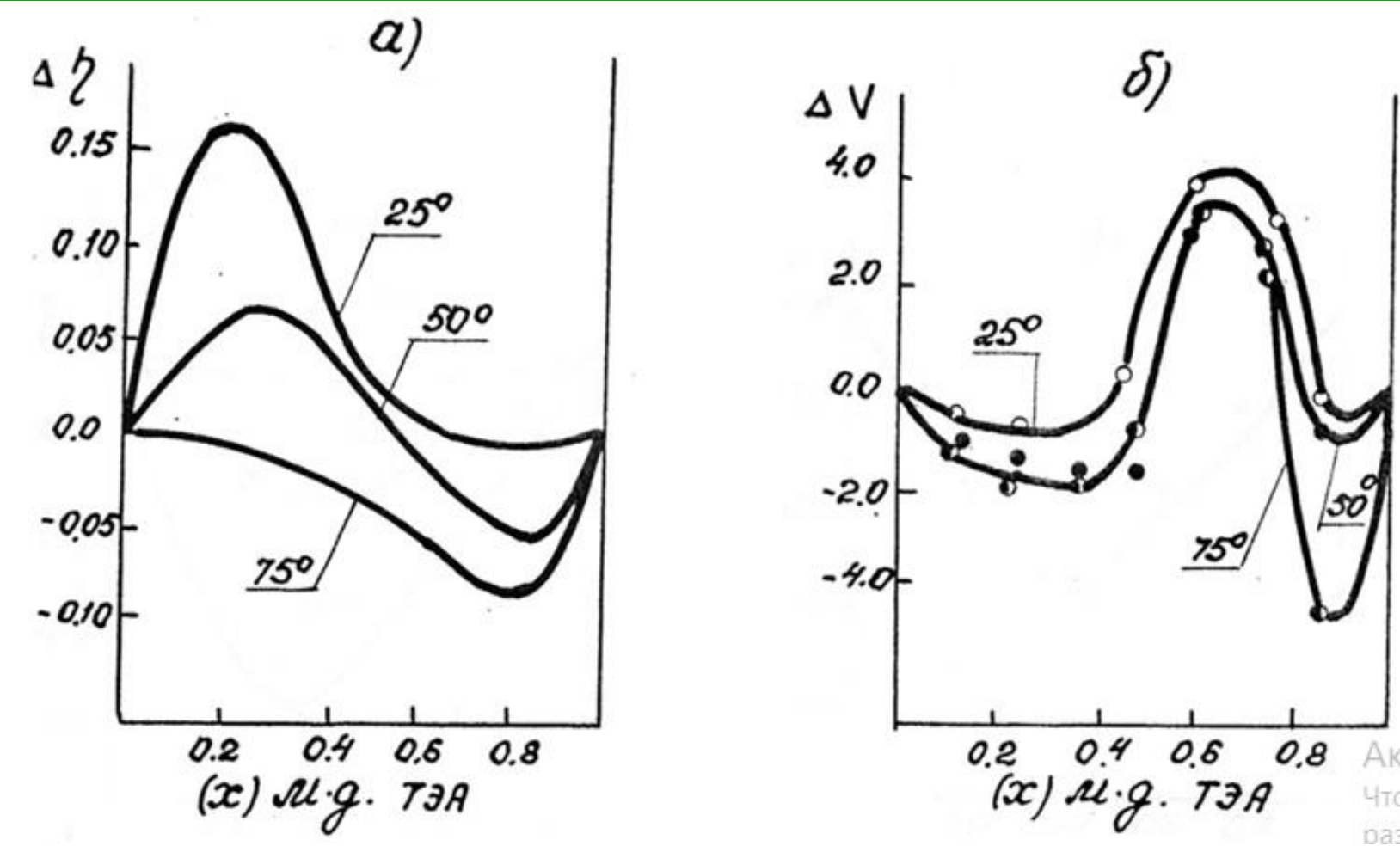

Рис. 2.16. Изотермы отклонений вязкости $\Delta \eta$ (а) и мольного объема $\Delta \mathrm{V}$ (б) в системе БЦ - ТЭА при температурах $25,50,75^{\circ} \mathrm{C}$

Проведенные исследования по изменению физико-химических свойств бинарных гомогенных систем: амин $-\mathrm{H}_{2} \mathrm{O} ; \mathrm{H}_{2} \mathrm{O}-$ полярный органический растворитель; амин - полярный органический растворитель выявили сильное межмолекулярное взаимодействие с образованием соединений: Амин $-\mathrm{H}_{2} \mathrm{O}$; Амин - ПОР и $\mathrm{H}_{2} \mathrm{O}-$ ПОР за счет образования межмолекулярных водородных связей, что коррелируется с данными [10, 31, 41, 42]. Силы межмолекулярных взаимодействий и стабильность комплексов убывает в ряду аминов: ДМЭА > ДЭА > ТЭА и в ряду растворителей: вода $>$ БЦ > ЭЦ> н-Б > БАЦ. Структура комплексов зависит от состава гомогенной бинарной системы и температуры. При $25^{\circ} \mathrm{C}$ состав межмолекулярных комплексов можно представить обобщенной формулой: $\mathrm{A} \cdot(1 \div 3) \cdot \mathrm{X}$, где $\mathrm{A}$ - молекула амина; $\mathrm{X}$ - молекулы воды или органического растворителя. При $50 \ldots 75^{\circ} \mathrm{C}$ комплексы частично разрушаются. 


\subsection{2 Фазовые равновесия в тройных системах \\ с низкомолекулярными компонентами}

Для исследования отражения бинарных межмолекулярных взаимодействий на стабильность пленкообразующих систем были изучены фазовые равновесия тройных систем с низкомолекулярными компонентами вода - амин - полярный органический растворитель (ПОР - БЦ, н-Б, БАЦ) и вода $-\Pi_{1}-\mathrm{OО}_{2}$, представляющие летучую часть ПОС в диапазоне температур $25 \ldots 75^{\circ} \mathrm{C}$. Методом изотермического титрования построены диаграммы фазовых равновесий, проведен анализ геометрического облика диаграмм, описан характер взаимодействий низкомолекулярных компонентов, определены границы стабильного состояния, найдены составы сосуществующих фаз. По положению критической точки на бинодальной кривой, направлению нод определено преобладающее взаимодействие бинарной системы. Корреляция нод проводилась по методу Бахмана: $\mathrm{X}_{\mathrm{BB}}=r+b\left(\mathrm{X}_{\mathrm{BB}} \mid \mathrm{X}_{\mathrm{AA}}\right)[47,48]$.

Влияние аминов, нейтрализаторов карбоксильных групп $-\mathrm{COOH}$ пленкообразователя на гетерогенные системы вода - ПОР показано на примере диаграмм фазовых равновесий в тройных системах вода - амин - БЦ (н-Б, БАЦ), представленных на рисунках 2.17 - 2.19, а целлозольвов - на рисунках $2.20-2.21$.

Тройные системы $\mathrm{H}_{2} \mathrm{O}$ - амин - ПОР образованы двумя бинарными гомогенными системами $\mathrm{H}_{2} \mathrm{O}$ - ДМЭА (ДЭА) и ДМЭА (ДЭА) - БЦ (н-Б или БАЦ) при температурах $25 \ldots 75^{\circ} \mathrm{C}$, в которых как было установлено ранее, протекают межмолекулярные взаимодействия с образованием комплексов переменного состава. Бинарная система вода - БЦ стабильна (гомогенна) в диапазоне концентраций $0 \ldots 100 \%$ при $25^{\circ} \mathrm{C}$ и не стабильна при $50 \ldots 75^{\circ} \mathrm{C}$ и расслаивается, так как имеет НКТС равную $49,1^{\circ} \mathrm{C}$. На диаграмме это 
отражается наличием одной гетерогенной области, примыкающей к стороне $\mathrm{H}_{2} \mathrm{O}$ - БЦ концентрационного треугольника, площадь которой увеличивается с увеличением температуры (рис.2.17).

a

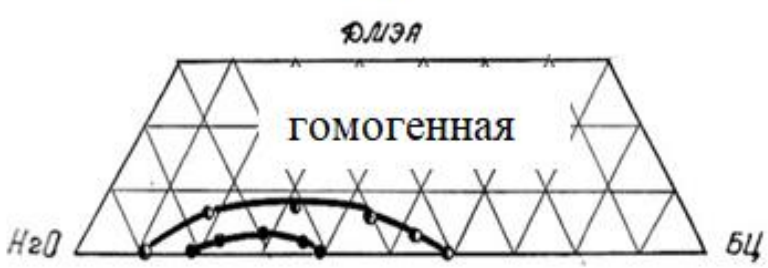

6

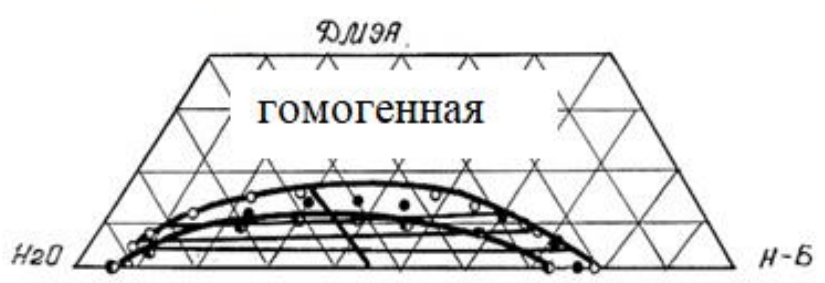

Рис. 2.17. Диаграммы фазовых равновесий при температурах $25,50,7^{\circ} \mathrm{C}$ в системах: а) вода-ДМЭА-БЦ; б) вода-ДМЭА-н-Б

Бинодальная кривая имеет максимум, который не совпадает с критической точкой изотермического титрования (КТС). За пределами критической точки тройная система находится в гомогенном, стабильном состоянии. При введении в эту систему ДМЭА происходит увеличение взаимной растворимости компонентов воды и БЦ до полной гомогенизации. Максимальный расход ДМЭА на гомогенизацию гетерогенной системы $\mathrm{H}_{2} \mathrm{O}$ - БЦ при $50^{\circ} \mathrm{C}$ составляет 0,5\%, а при $75^{\circ} \mathrm{C}-9 \%$ (рис.2.17). Снижение гомогенизирующего действия ДМЭА вызвано наличием НКТС и ВКТС в бинарной системе $\mathrm{H}_{2} \mathrm{O}$ - БЦ. Гомогенизирующее действие аминов обнаружено и в системе $\mathrm{H}_{2} \mathrm{O}$ - н-Б (рис.2.17 б, 2.18 б) и на системы $\mathrm{H}_{2} \mathrm{O}$ - БАЦ.
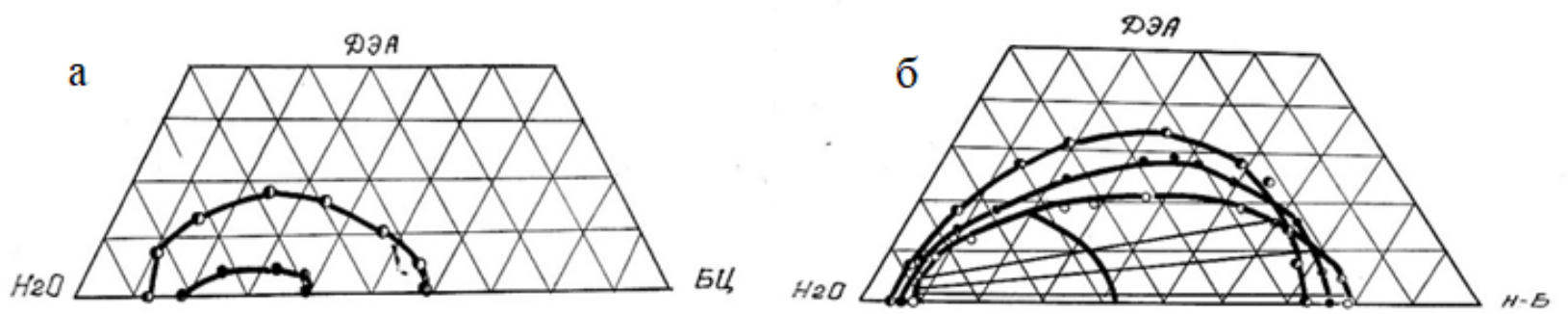

Рис. 2.18. Диаграммы фазовых равновесий в системах:

а) $\mathrm{H}_{2} \mathrm{O}$ - ДЭА - БЦ при температурах $50,7^{\circ} \mathrm{C}$; б) $\mathrm{H}_{2} \mathrm{O}$ - ДЭА - н-Б при температурах $25,50,7^{\circ} \mathrm{C}$ 
В системе вода-ДМЭА-н-Б (рис.2.17б) ноды расходятся в сторону ДМЭА-н-Б, что свидетельствуют о преобладающем взаимодействии комплексов ДМЭА•н-Б, перестройке состава и структуры гомогенизирующего комплекса и образования сложных структурных элементов. Максимальный расход ДМЭА на систему $\mathrm{H}_{2} \mathrm{O}-\mathrm{H}-Б$ составляет $11 \ldots$ 18\% при температурах $25 \ldots 75^{\circ} \mathrm{C}$. Расход на гомогенизацию сольватов ДМЭА или ДЭА на систему $\mathrm{H}_{2} \mathrm{O}$ - БАЦ увеличивается и составляет 30..50\%. ДМЭА [49]. При этом преобладающим взаимодействием в системе $\mathrm{H}_{2} \mathrm{O}$-БАЦ-ДЭА обладают комплексы БАЦ•ДЭА, а в системе вода-ДМЭА-БАЦ - водные комплексы амина $\mathrm{H}_{2} \mathrm{O}$. Аналогичное действие на гетерогенные системы $\mathrm{H}_{2} \mathrm{O}$ - БЦ и $\mathrm{H}_{2} \mathrm{O}$ - н-Б оказывает и ДЭА (рис. 2.18 а, б). Гомогенизирующее действие сольватных комплексов ДЭА в 10 раз меньше, чем ДМЭА.

В отличие от ДЭА и ДМЭА триэтиамин ограниченно совмещается с водой при $25^{\circ} \mathrm{C}$, так как имеет НКТС равную $18,6^{\circ} \mathrm{C}$. Поэтому в дальнейшем были исследованы фазовые равновесия в тройных низкомолекулярных системах вода - ТЭА - ЭЦ (БЦ, н-Б, БАЦ) при $25 . .75^{\circ} \mathrm{C}$ во всем диапазоне концентрационного треугольника Гибса-Розебома (рис.2.19). На диаграммах фазовых равновесий бинодальная кривая при $25^{\circ} \mathrm{C}$ в этих системах, разделяющая гомогенную и гетерогенную области, имеет максимум, а при увеличении температуры да $50 . .75^{\circ} \mathrm{C}$ в системе $\mathrm{H}_{2} \mathrm{O}$ - ТЭА - БЦ происходит слияние ее с бинодальной кривой системы $\mathrm{H}_{2} \mathrm{O}$ - БЦ и она приобретает вид полосы (рис. 2.19.б).
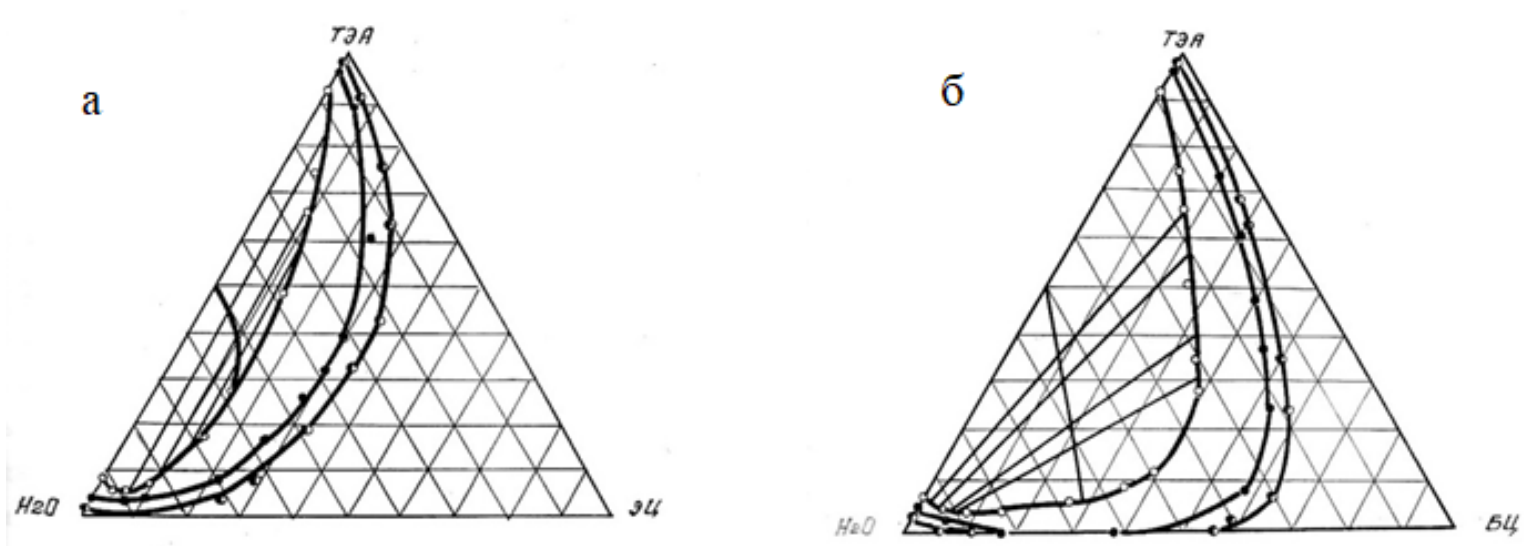

Рис. 2.19. Диаграммы фазовых равновесий при температурах $25,50,7^{\circ} \mathrm{C}$ в системах: а) $\mathrm{H}_{2} \mathrm{O}-$ ТЭА - ЭЦ; б)Н $2 \mathrm{O}-\mathrm{TЭА-БЦ}$ 


\section{СТАБИЛИЗАЦИЯ СВОЙСТВ ТОПЛИВНО-ЭНЕРГЕТИЧЕСКИХ СИСТЕМ НА ОСНОВЕ ПРИРОДНЫХ И СИНТЕТИЧЕСКИХ ПОЛИМЕРОВ}

Слияние бинодальных кривых происходит из-за уменьшения взаимной растворимости компонентов в бинарных системах $\mathrm{H}_{2} \mathrm{O}-$ ТЭА и $\mathrm{H}_{2} \mathrm{O}-$ БЦ с повышением температуры. Сольватные комплексы целлозольвов оказывают гомогенизирующее действие на систему вода - ТЭА при $25^{\circ} \mathrm{C}$, то есть увеличивают взаимную растворимость компонентов гетерогенных бинарных систем. Гомогенизирующий эффект комплексов ЭЦ больше, чем БЦ и уменьшается с повышением температуры в $2 \ldots 3$ раза. Ноды в системе $\mathrm{H}_{2} \mathrm{O}$ - ТЭА - ЭЦ расходятся в сторону $\mathrm{H}_{2} \mathrm{O}$ - ЭЦ, а $\mathrm{H}_{2} \mathrm{O}$ - ТЭА - БЦ в сторону ТЭА - БЦ и свидетельствуют о преобладающем взаимодействии в этих бинарных системах. В системе $\mathrm{H}_{2} \mathrm{O}$ - ТЭА - БЦ наблюдается конкуренция между эффектом гомогенизации (всаливанием) БЦ в гетерогенной системе $\mathrm{H}_{2} \mathrm{O}$-ТЭА и высаливанием ТЭА в системе $\mathrm{H}_{2} \mathrm{O}$ 一БЦ, то есть уменьшение взаимной растворимости между молекулами БЦ и $\mathrm{H}_{2} \mathrm{O}$ при добавлении к ним ТЭА. Гомогенизирующее действие целлозольвов (ЭЦ и БЦ) проявляется не только на гетерогенную систему $\mathrm{H}_{2} \mathrm{O}$ - ТЭА, но и на гетерогенные системы $\mathrm{H}_{2} \mathrm{O}$ - БЦ (н-Б или БАЦ) (рис.2.20).

a

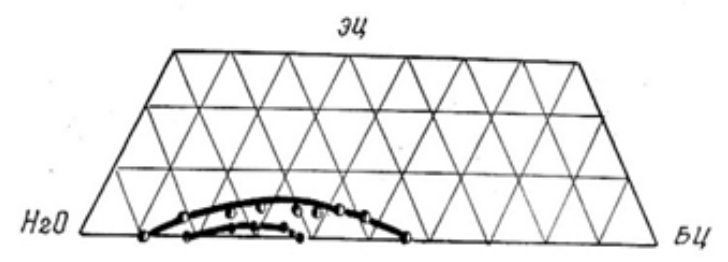

б

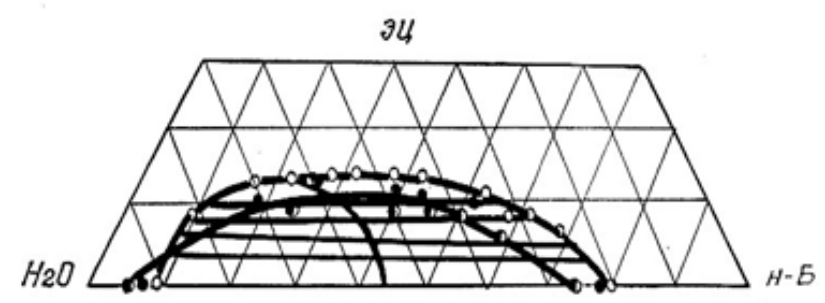

Рис. 2.20. Диаграммы фазовых равновесий при температурах $50,75^{\circ} \mathrm{C}$ в системах: a) $\mathrm{H}_{2} \mathrm{O}$ - БЦ - ЭЦ; б) $\mathrm{H}_{2} \mathrm{O}$ - БЦ - н-Б

Следует отметить, эффект гомогенизации ЭЦ больше, чем ДМЭА (рис. $2.17 \mathrm{a})$ в системе $\mathrm{H}_{2} \mathrm{O}$ - БЦ (рис. 2.20a). С повышением температуры на $25^{\circ} \mathrm{C}$ гомогенизация ЭЦ в системе так же ослабевает. Положение критической точки изотермического титрования и направление нод (рис. 2.20б) указывают на преобладающее взаимодействие комплекса состава ЭЦ•н-Б. Гомогенизирующее 
действие ЭЦ больше БЦ и уменьшается в ряду ПОР: БЦ > н-Б > БАЦ. Меньший гомогенизирующий эффект БЦ на гетерогенные смеси $\mathrm{H}_{2} \mathrm{O}-$ н-Б и $\mathrm{H}_{2} \mathrm{O}$ - БАЦ обусловлен его ограниченной совместимостью с водой при $50 \ldots 75^{\circ} \mathrm{C}$.

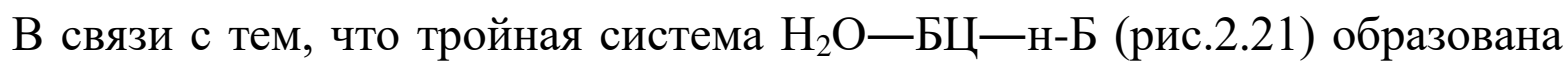
двумя гетерогенными бинарными системами $\mathrm{H}_{2} \mathrm{O}-$ БЦ и $\mathrm{H}_{2} \mathrm{O}-$ н-Б, то гомогенизирующее действие БЦ проявляется только при $25^{\circ} \mathrm{C}$.

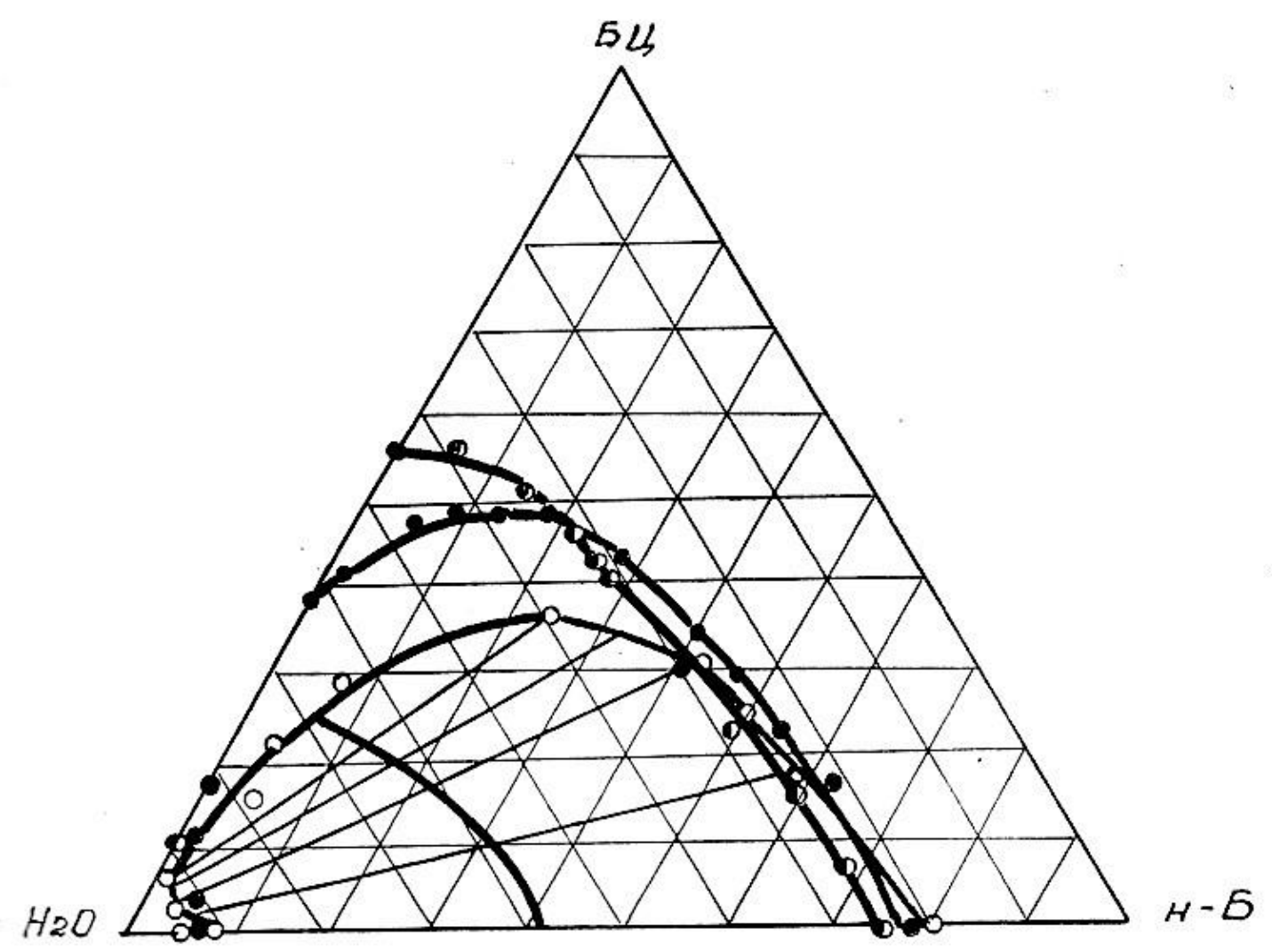

Рис. 2.21. Диаграмма фазовых равновесий в системе $\mathrm{H}_{2} \mathrm{O}-$ БЦ - н-Б при температурах $25,50,75^{\circ} \mathrm{C}$

С повышением температуры уменьшается взаимная растворимость в бинарных системах и исчезает гомогенизирующий эффект БЦ на систему $\mathrm{H}_{2} \mathrm{O}$ - н-Б. На диаграмме фазовых равновесий это отражается в изменении вида бинодальной кривой (полосы) и увеличении площади гетерогенного 
состояния. Ноды расходятся в сторону гомогенной системы БЦ - н-Б. Гомогенизирующий эффект БЦ при $25^{\circ} \mathrm{C}$ на гетерогенную систему $\mathrm{H}_{2} \mathrm{O}-$ н-Б больше, чем на систему $\mathrm{H}_{2} \mathrm{O}$ - БАЦ в 2 раза.

Таким образом, исследования фазовых равновесий тройных низкомолекулярных систем вода - амин - ПОР позволили выявить гомогенизирующее действие аминов (ДЭА и ДМЭА) на гетерогенные бинарные системы вода - ПОР, которое ослабевает при повышении температуры $50 \ldots 75^{\circ} \mathrm{C}$ ряду: $\mathrm{H}_{2} \mathrm{O}>$ БЦ $>$ ЭЦ $>$ н-Б $>$ БАЦ и в ряду аминов: ДМЭА > ДЭА > ТЭА, коррелирующее с уменьшением межмолекулярного взаимодействия в комплексах переменного состава в бинарных системах в ряду аминов: ДМЭА > ДЭА > ТЭА и в ряду: $\mathrm{H}_{2} \mathrm{O}>$ БЦ $>$ ЭЦ $>$ н-Б $>$ БАЦ. Полученные результаты позволили сформулировать гипотезу о роли низкомолекулярных комплексов переменного состава на гомогенизирующий эффект тройных низкомолекулярных систем вода - амин - ПОР, обосновать выбор эффективного амина для нейтрализации -СООН групп ПО, определить области стабильного состояния ПОС.

\subsection{3 Влияние эффективных гомогенизаторов на стабильность пленкообразующих систем}

\subsubsection{1 Фазовые равновесия в бинарных и тройных системах с модельными олигоэфирами}

Для подтверждения данной гипотезы исследовались фазовые равновесия в системах вода - ОЭФ $\Phi_{1}\left(О Э \Phi_{2}\right.$, ОЭФ $\left.{ }_{3}\right)-$ ПОР. В качестве водоразбавляемых олигэфирных пленкообразователей использовались модельные олигоэфиры, синтезированные на основе мономеров адипиновой кислоты и пентаэритрита при их мольном соотношении кислота:спирт $=1,0: 0,84$ поликонденсационным способом с содержанием концевых карбоксильных групп 6, 30, 50 мг (ОЭФ $)$ 


\section{СТАБИЛИЗАЦИЯ СВОЙСТВ ТОПЛИВНО-ЭНЕРГЕТИЧЕСКИХ СИСТЕМ НА ОСНОВЕ ПРИРОДНЫХ И СИНТЕТИЧЕСКИХ ПОЛИМЕРОВ}

КОН/г. Исследования фазовых равновесий бинарных систем ОЭФ - полярный растворитель проводились при нагревании гетерогенных составов со скоростью один градус в минуту. Переход из гетерогенного в гомогенное состояние происходит через область метастабильного состояния и на диаграмме фазовых равновесий имеются две равновесные кривые: бинодальная -1 и спинодальная - 2. Олигоэфиры с кислотными числами 6 мг КОН/г - ОЭФ 1 и 30 мг КОН/г ОЭФ $\Phi_{2}$ при температуре $20^{\circ} \mathrm{C}$ не совмещаются с $\mathrm{H}_{2} \mathrm{O}$, ЭЦ или БЦ во всем диапазоне концентраций. $\mathrm{C}$ повышением температуры увеличивается совместимость модельных олигоэфиров с ЭЦ (рис. 2.22 а,б) или БЦ (рис.2.22 в) и достигает $30 \ldots 40 \%$ при $80 \ldots 90^{\circ} \mathrm{C}$. Повышение кислотного числа до 50 мг КОН/Г приводит к повышению растворимости модельного олигоэфира в области концентраций ОЭФ $30 \ldots 70 \%$ (рис.2.22 г).

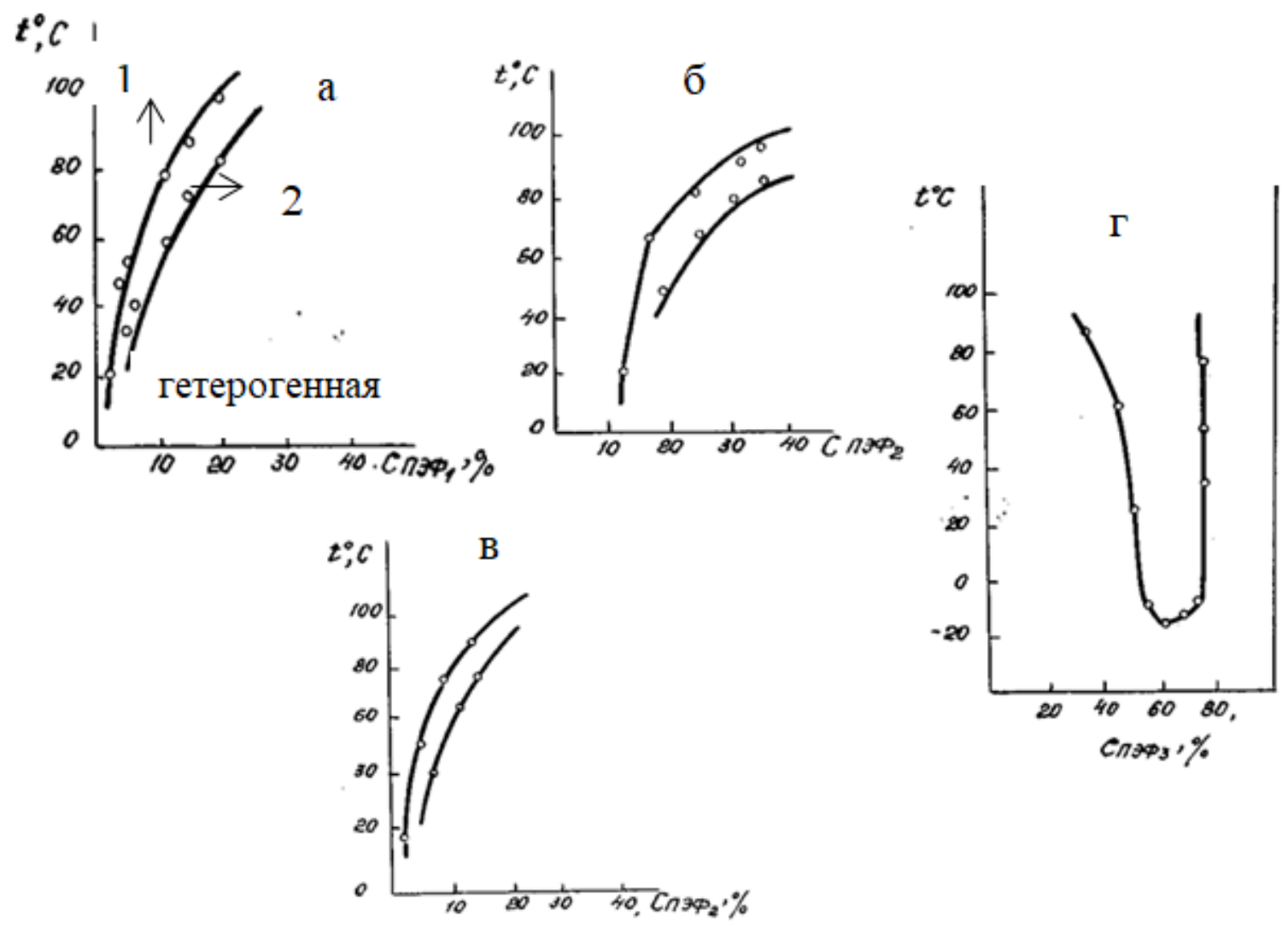

Рис. 2.22. Диаграммы фазовых равновесий систем: а) ОЭФ - ЭЦ; б) ОЭФ 2 -ЭЦ; в) ОЭФ - БЦ; г) Н2О - ОЭФ кривая 2 - спинодаль 
Растворимость ОЭФ увеличивается в смешенном полярном растворителе, например, $\mathrm{H}_{2} \mathrm{O}$-ЭЦ (БЦ) (синергизм). Бинодальная кривая ассиметрична, имеет максимум, который смещен к стороне ОЭФ - ЭЦ (рис. 2.23 а) или находится в области средних концентраций треугольника Гиббса-Розебома (рис. 2.23 б). Гомогенная область примыкает к стороне $\mathrm{H}_{2} \mathrm{O}-$ ЭЦ (БЦ) концентрационного треугольника.

a)

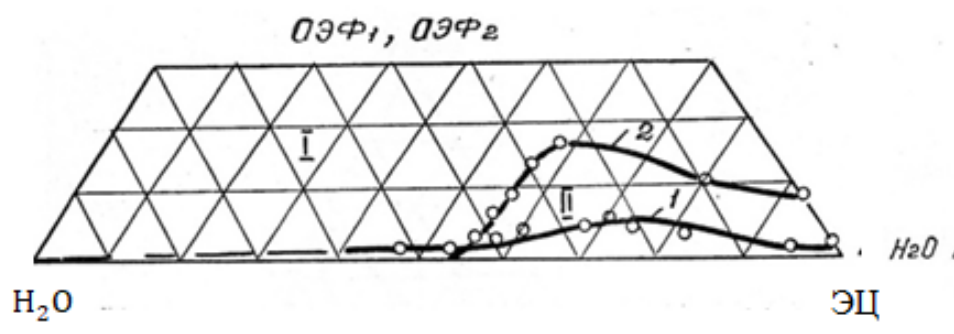

б)

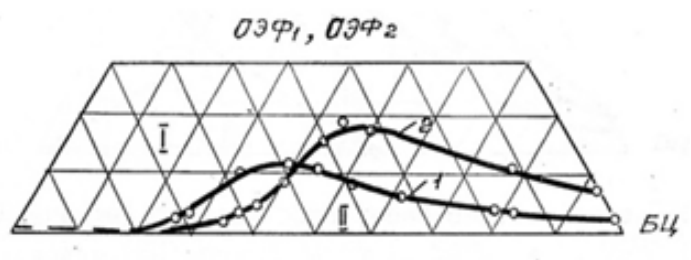

Рис. 2.23. Диаграммы фазовых равновесий при температуре $25^{\circ} \mathrm{C}$ в системах: а) вода-ОЭФ-этилцеллозольв,

б) вода-ОЭФ-бутилцеллозольв; кривая 1 - ОЭФ 1 ; кривая 2 - ОЭФ I -гетерогенная область; II-гомогенная область

Большую часть концентрационного треугольника $(\approx 80 \%)$ занимает область гетерогенного состояния. Пленкообразующая система стабильна только в области низких концентраций пленкообразователя и узком концентрационном интервале низкомолекулярных растворителей, например $\mathrm{H}_{2} \mathrm{O}: Б Ц=1: 1$, и при концентрации ПО 10 ... 20\%. В этом диапазоне концентраций обнаружено сильное межмолекулярное взаимодействие низкомолекулярных компонентов с образованием устойчивых комплексов БЦ• $2 \mathrm{H}_{2} \mathrm{O}$. Можно предположить, что эффект синергизма обусловлен сильным влиянием низкомолекулярного комплекса на конформацию олигомерных молекул ОЭФ и повышение их растворимости в смеси $\mathrm{H}_{2} \mathrm{O}-$ БЦ. 

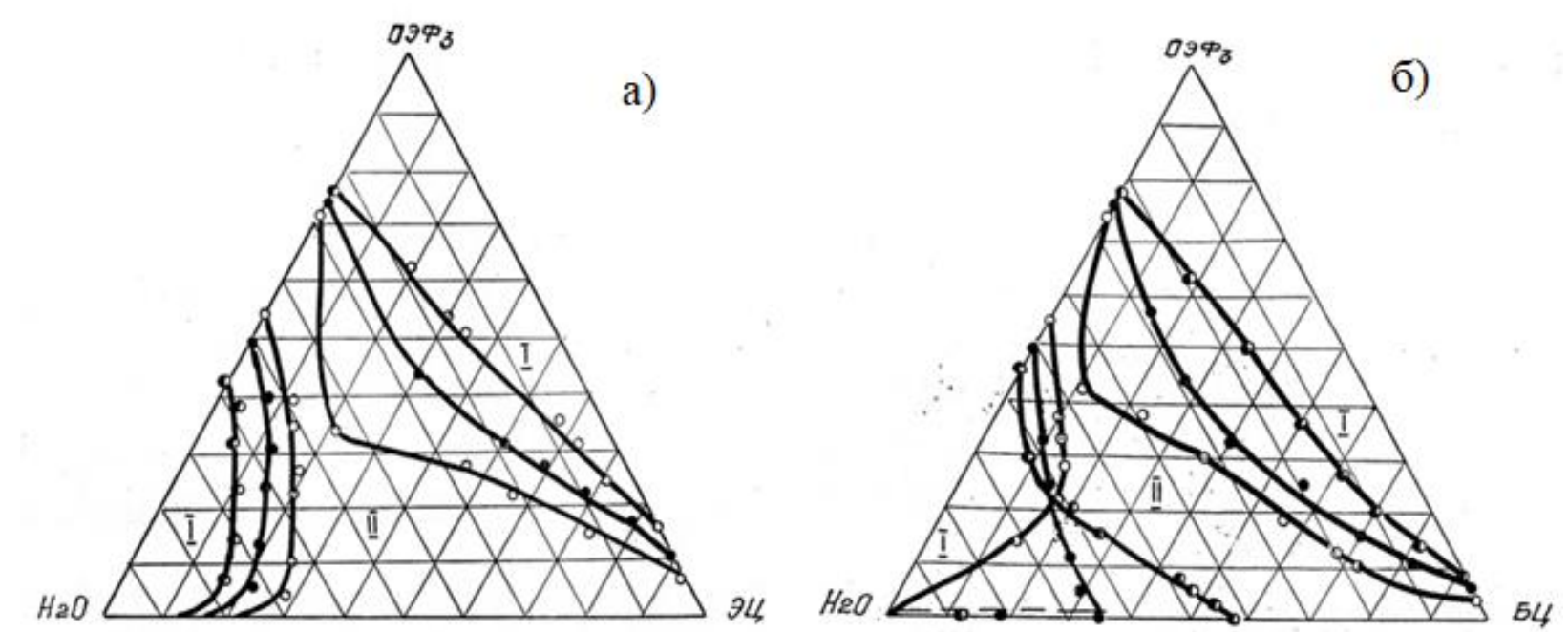

Рис. 2.24. Диаграммы фазовых равновесий при температурах $25,50,7^{\circ} \mathrm{C}$ в системах: а) вода - ОЭФ 3 - ЭЦ, б) вода - ОЭФ 3 - БЦ;

I -гетерогенная область; II- гомогенная область

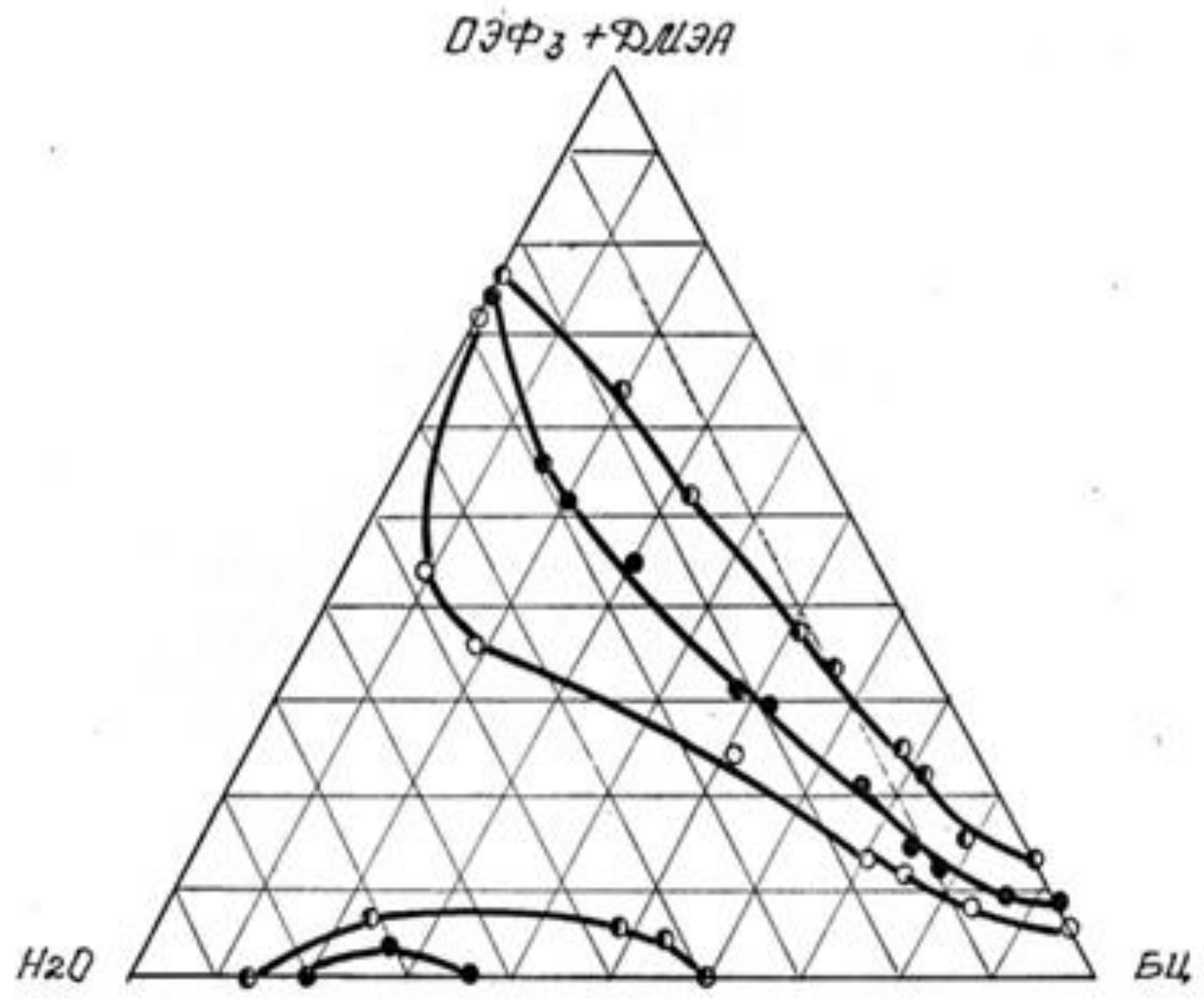

Рис. 2.25. Диаграмма фазовых равновесий в системе

Вода-ОЭФ область, II - гомогенная область 


\section{СТАБИЛИЗАЦИЯ СВОЙСТВ ТОПЛИВНО-ЭНЕРГЕТИЧЕСКИХ СИСТЕМ НА ОСНОВЕ ПРИРОДНЫХ И СИНТЕТИЧЕСКИХ ПОЛИМЕРОВ}

Дальнейшее исследование влияния межмолекулярных взаимодействий низкомолекулярных компонентов на фазовое состояние осуществляли на примере модельной системы $\mathrm{H}_{2} \mathrm{O}-$ ОЭФ 3 - ЭЦ (БЦ) (рис.2.24) и $\mathrm{H}_{2} \mathrm{O}-$

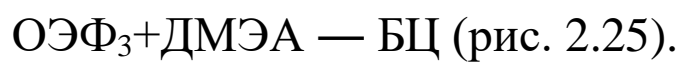

Выбор исходных компонентов обусловлен повышенной растворимостью ОЭФ $\Phi_{3}$ в воде, гомогенизирующим действием ДМЭА на гетерогенные системы, меньшим расходом ДМЭА на нейтрализацию карбоксильных групп ОЭФ Диаграмма фазовых равновесий Вода - ОЭФ 3 - БЦ имеет сложный геометрический облик. При $25^{0} \mathrm{C}$ имеются две гетерогенные области, примыкающие к стороне вода - ОЭФ и БЦ- ОЭФ $_{3}$ (рис. 2.24 a).

С повышением температуры $50 \ldots 75^{\circ} \mathrm{C}$ система $\mathrm{H}_{2} \mathrm{O}-$ БЦ начинается расслаиваться, так как имеет НКТС и площадь гетерогенной области увеличивается. При $50^{\circ} \mathrm{C}$ гетерогенная область примыкает к стороне бинарной системы вода - БЦ. При нейтрализации ОЭФ ${ }_{3}$ ДМЭА наблюдается гомогенизирующий эффект аминосоли олигоэфира на систему $\mathrm{H}_{2} \mathrm{O}$ - БЦ (рис. 2.25), который коррелируется с эффектом гомогенизации ДМЭА на эту бинарную систему (рис.2.19a).

Максимальный расход аминосоли ОЭФ ...ДМЭА на гомогенизацию гетерогенных составов вода-БЦ при $50^{\circ} \mathrm{C}$ составляет $0,5 \%$, а при $75^{\circ} \mathrm{C}-9 \%$.

Растворимость модельных олигоэфиров в полярном растворителе увеличивается с увеличением кислотного числа с 6мг КОН/г до 30 мг КОН/г в ряду синтетических олигоэфиров: ОЭФ $<$ ОЭФ $2<$ ОЭФ $\Phi_{3}$ и ряду полярных растворителей: $\mathrm{H}_{2} \mathrm{O}<$ БЦ <ЭЦ. Обнаруженный эффект синергизма обусловлен взаимодействием низкомолекулярных комплексов с полярными функциональными группами макромолекул олигоэфира. При нейтрализации карбоксильных групп амином наблюдается гомогенизирующий эффект, коррелирующий с эффектом гомогенизации этих аминов на гетерогенные низкомолекулярные системы $\mathrm{H}_{2} \mathrm{O}$ - полярный органический растворитель $[50$, c. 72$]$. 


\subsubsection{2 Фазовые равновесия в системах с модифицированным олигоэфиром ВПФСинА}

Модифицированный олигоэфир ВПФСинА (к.ч. = 48 мг КОН/г), синтезирован в ГИПИ ЛКП, входит в состав эмали ВПЭ-1179 [51] и имеет сходство с модельным олигоэфиром ОЭФ. В отличие от модельного олигоэфира ОЭФ ${ }_{3}$ модифицированный опытный образец олигоэфира ВПФСинА неограниченно совмещается с полярными органическими растворителями (ЭЦ, БЦ, н-Б, БАЦ) и не совмещается с водой при $25 \ldots 75^{\circ} \mathrm{C}$. Исследование геометрического облика диаграмм фазовых равновесий тройных систем $\mathrm{H}_{2} \mathrm{O}-\mathrm{BПФсин.А-ПОР} \mathrm{(рис.} \mathrm{2.26)} \mathrm{показало,} \mathrm{что} \mathrm{большую} \mathrm{площадь}$ треугольника занимает гетерогенная область, которая примыкает к стороне $\mathrm{H}_{2} \mathrm{O}$-ВПФсинА.

Переход из гетерогенного в гомогенное состояние осуществляется через область метастабильного состояния (II), которая исчезает при повышении температуры до $50 \ldots 75^{\circ} \mathrm{C}$. Аналогичный геометрический облик диаграмм фазовых равновесий обнаружен и в системах $\mathrm{H}_{2} \mathrm{O}-$ ВПФСинА - н-Б (рис. 2.26 б) или $\mathrm{H}_{2} \mathrm{O}$ - ВПФСинА - ЭЦ (БАЦ).
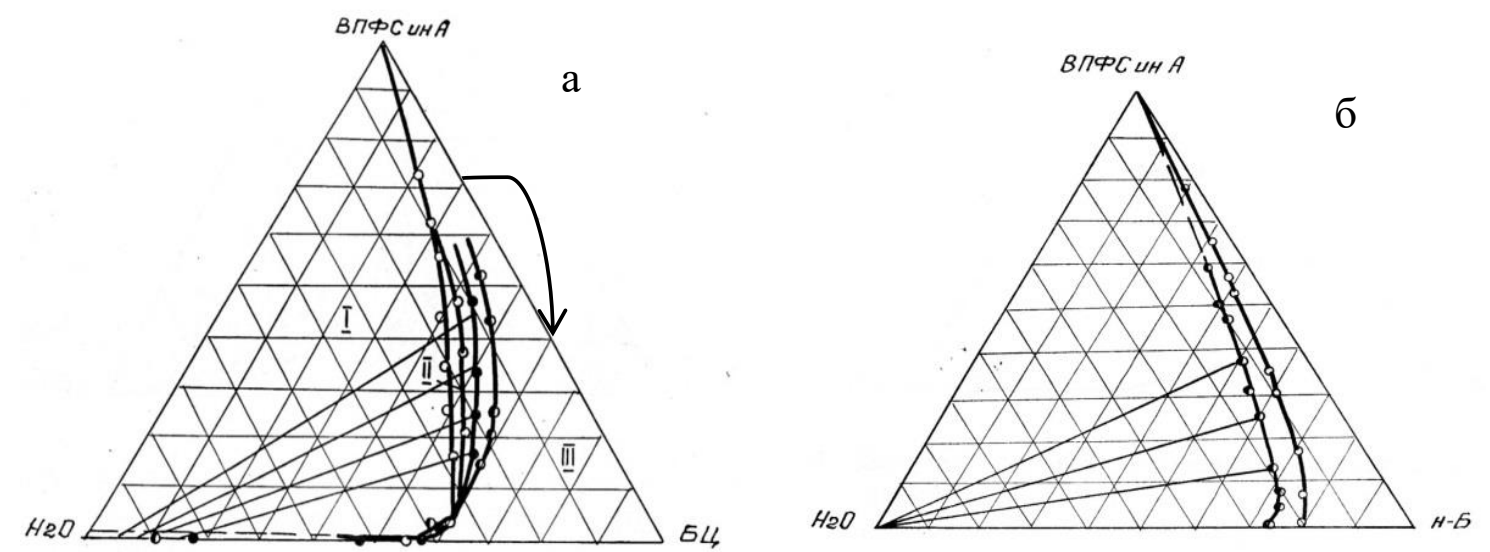

Рис. 2.26. Диаграммы фазовых равновесий при температурах $25,50,75^{\circ} \mathrm{C}$ в системах: а) $\mathrm{H}_{2} \mathrm{O}$ - ВПФСинА - БЦ; б) $\mathrm{H}_{2} \mathrm{O}$ - ВПФСинА - н-Б;

I-гетерогенная область; II-метастабильная область; III -гомогенная область 
Направление нод указывает на преобладающее взаимодействие олигоэфира с органическим растворителем. Площадь гомогенного состояния уменьшается с повышением температуры в ряду растворителей: БЦ > ЭЦ > Н-Б > БАЦ.

При разбавлении исходного лака разбавителем до рабочей вязкости концентрация пленкообразователя снижается с 70\% до $30 \ldots 40 \%$. Если в качестве разбавителя использовать воду, то при этих условиях ПОС будет находится в области гетерогенного состояния и с течением времени будет расслаиваться. Данная ПОС будет стабильна при содержании воды до 5\% (рис. $2.26 \mathrm{a}$ ).

Дальнейшее исследование влияния низкомолекулярных компонентов на стабильность водоразбавляемых ПОС оценивали по изменению геометрического облика диаграмм фазовых равновесий $\mathrm{H}_{2} \mathrm{O}$ ВПФСинА+амин - ПОР. Наибольший эффект при нейтрализации карбоксильных групп ВПФСинА обнаружен при использовании ДМЭА в среде БЦ. На диаграмме фазовых равновесий это отражается в увеличении области гомогенного, стабильного состояния (рис. 2.27 а). Площадь стабильного состояния системы при $25^{\circ} \mathrm{C}$ увеличивается в 2,5 раза в широком диапазоне концентраций воды и может составлять до $60 \ldots 70 \%$. При повышении температуры до $50^{\circ} \mathrm{C}$ увеличивается область метастабильного состояния, которая исчезает при температуре $75^{\circ} \mathrm{C}$ (рис. 2.27 б).

a

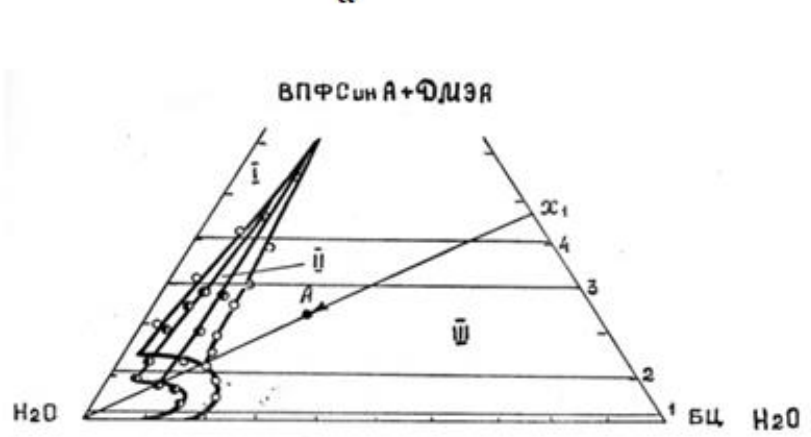

Рис. 2.27. Диаграммы фазовых равновесий в системе б

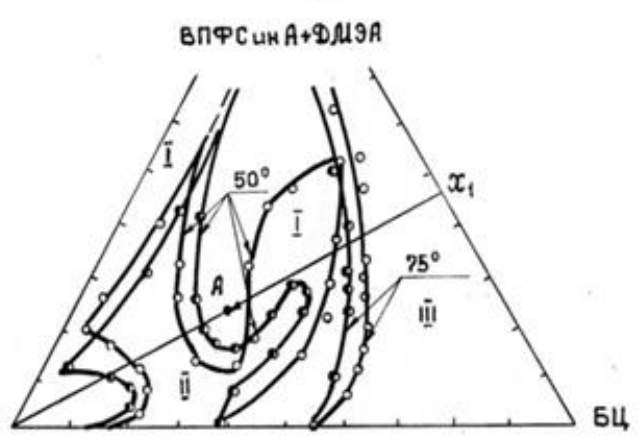
64

ВПФСинА+ДМЭА — БЦ при температурах: а) $25^{\circ} \mathrm{C}$; б)50,750

I-гетерогенная область; II-метастабильная область; III -гомогенная область 


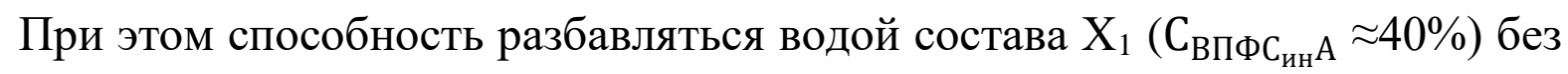
нарушения стабильности резко снижается и становится такой же как и без ДМЭА. Аналогичная зависимость обнаружена при нейтрализации олигоэфира ВПФСинА ДЭА и ТЭА. При замене основного растворителя для ВПФСинА бутилцеллозольва на ЭЦ, н-Б или БАЦ эффективность амина, как нейтрализатора - $\mathrm{COOH}$ групп резко снизилась, что отразилось на геометрическом облике диаграмм фазовых равновесий (рис. 2.28). Вероятно, это связано с ограниченной растворимостью бинарной системы вода - БЦ (н-Б, БАЦ) и снижением гомогенизирующего действия ДМЭА в этих системах и более слабым взаимодействием ДМЭА с н-Б или БАЦ.

a

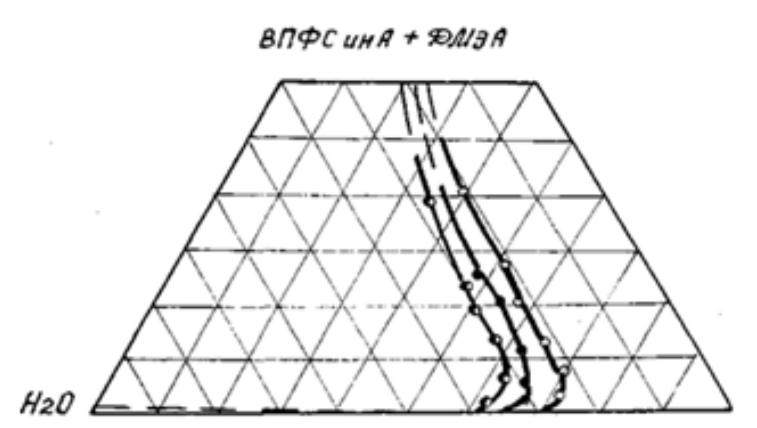
94

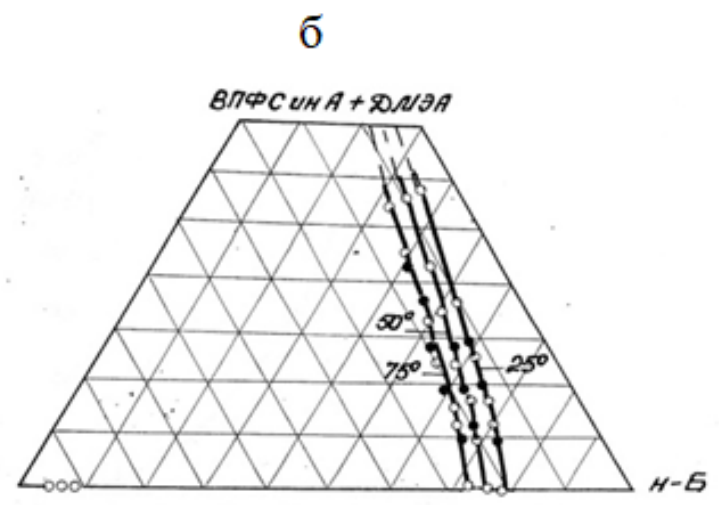

Рис. 2.28. Диаграммы фазовых равновесий при температурах $25^{\circ}, 50,75^{\circ} \mathrm{C}$ в системах: а) $\mathrm{H}_{2} \mathrm{O}$ - ВПФСинА+ДМЭА - ЭЦ;

б) $\mathrm{H}_{2} \mathrm{O}-$ ПФСИнА+ДМЭА - н-Б

Обобщенные данные анализа фазовых равновесий в системах с модифицированным опытным образцом олигоэфиром ВПФСинА свидетельствуют об уменьшении площади гомогенного стабильного состояния ПОС ряду полярных органических растворителей: БЦ > ЭЦ > н-Б > БАЦ и в ряду аминов: ДМЭА > ДЭА > ТЭА в интервале температур $25 \ldots . .75^{\circ} \mathrm{C}$, что коррелируется с изменением характера межмолекулярных взаимодействий низкомолекулярных органических соединений. Эффективность амина как нейтрализатора карбоксильных групп олигоэфира и гомогенизатора 


\section{СТАБИЛИЗАЦИЯ СВОЙСТВ ТОПЛИВНО-ЭНЕРГЕТИЧЕСКИХ СИСТЕМ НА ОСНОВЕ ПРИРОДНЫХ И СИНТЕТИЧЕСКИХ ПОЛИМЕРОВ}

гетерогенных смесей коррелируется с отклонением избыточных функций вязкости, плотности, мольного объема, времени релаксации, химического сдвига низкомолекулярных гомогенных бинарных смесей амин - вода (или полярный органический растворитель) и подтверждает выдвинутую ранее гипотезу о роли низкомолекулярных взаимодействий на растворимость синтетических полимеров в полярных растворителях и на стабильность растворов пленкообразующих систем.

Предложена модель строения раствора олигоэфира в смеси водаполярный органический растворитель, в основе которой лежит гипотеза о послойном формировании сольватных оболочек вокруг ионогенных (- $\mathrm{COOH})$ и не ионогенных групп (-OH) олигоэфира, при взаимодействии которых образуются структурные элементы олигоэфира, стабилизирующие структуру воды:

$$
\left\{\mathrm{R}_{-(\mathrm{OH})_{m}}^{-(\mathrm{COOH})_{n}} \vdots \mathrm{M}_{\mathrm{a}}\right\} \vdots \mathrm{M}_{\mathrm{p}} \vdots \mathrm{M}_{\mathrm{t}} \vdots \mathrm{M}_{\text {}},
$$

где $R$ - углеводородная часть олигоэфира; $\mathrm{n}$ - число - $\mathrm{COOH} \mathrm{групп;} \mathrm{m}-$ число - $\mathrm{OH}$ групп; $\mathrm{M}_{\mathrm{a}}$ - молекулы амина, находящихся в ближнем окружении; $\mathrm{M}_{\mathrm{p}}$ - молекулы воды, находящихся в дальнем окружении; $\mathrm{M}_{\mathrm{t}}-$ молекулы полярного органического растворителя, находящихся в дальнем окружении; $\mathrm{M}_{\text {ж }}$ - число свободных молекул растворителя; : - границы оболочек структурных элементов олигоэфира.

\subsubsection{3 Фазовые равновесия в системах вода - ВМФ - растворитель}

Водорастворимые аминоформальдегидные олигомеры используют в ЛКМ для ускорения процесса отверждения водоразбавляемой полиэфирной эмали ВПЭ-1179 и представляют собой продукты конденсации мочевины (карбамида) или меламина с формальдегидом, модифицированный бутанолом (к.ч. 2 .. 5 мг КОН /г. Недостатком исходного раствора меламиноформальдегидной смолы в н-бутаноле ( $\approx 50$ \%) является низкая 
стабильность при хранении вследствие реакций конденсации и разбавлении водой.

Структурный элемент меламиноформальдегидной смолы представлен на рисунке 2.29 .

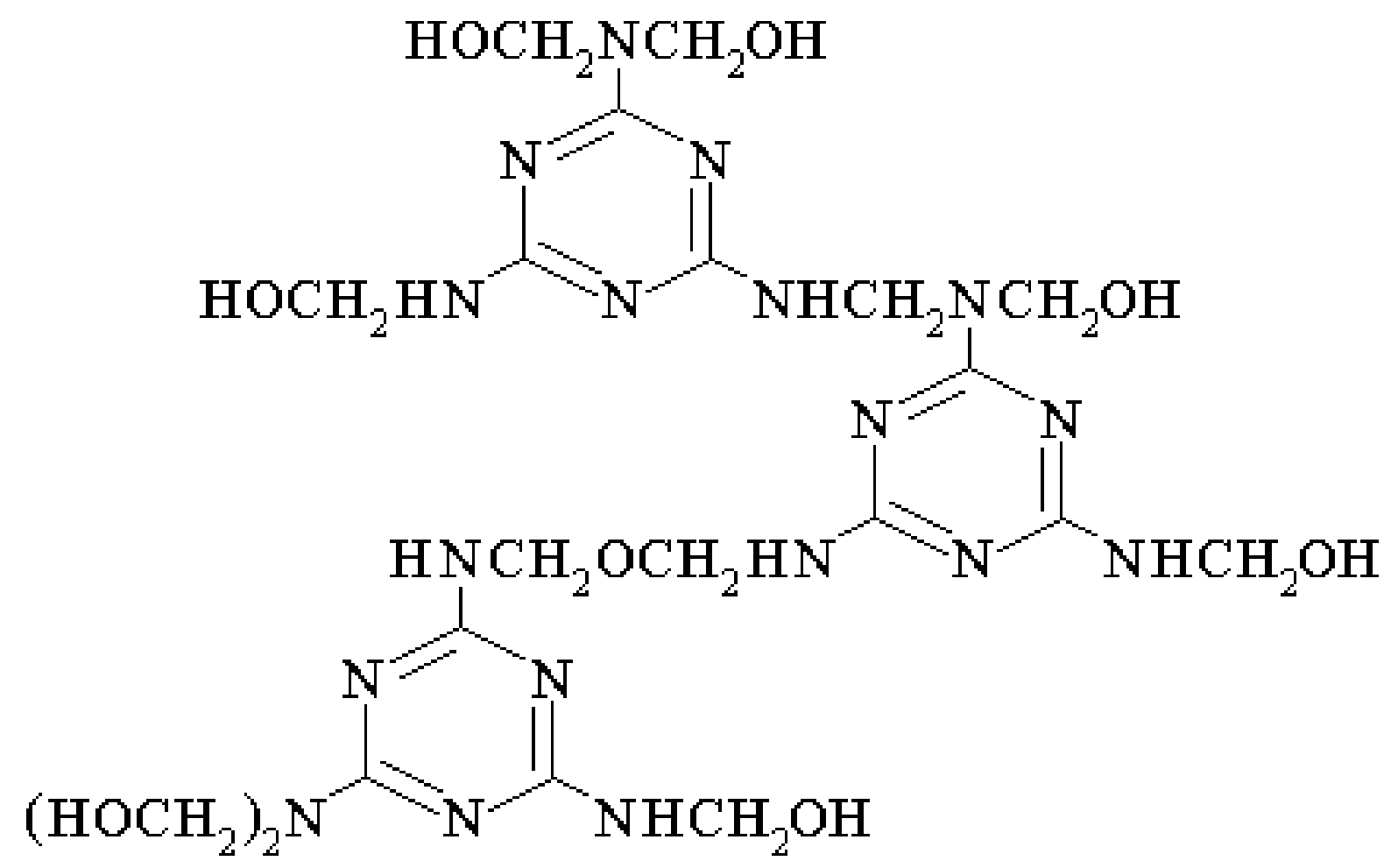

Рис. 2.29. Структура меламиноформальдегидного пленкообразователя

Анализ геометрического облика диаграмм фазовых равновесий систем вода - ВМФ - н-Б (ЭЦ, БЦ) при $25 \ldots 75^{\circ} \mathrm{C}$ свидетельствует об узком диапазоне концентраций воды 5..15\% (рис. 2.30a), при котором эта система стабильна. Нарушение стабильности в области высоких концентраций полимера (50...70\%) меламиноформальдегидной смолы в н-бутаноле при разбавлении водой обусловлено высаливающим действием ВМФ на гетерогенную низкомолекулярную систему вода - н-бутанол при температурах ниже ВКТС. 
a)

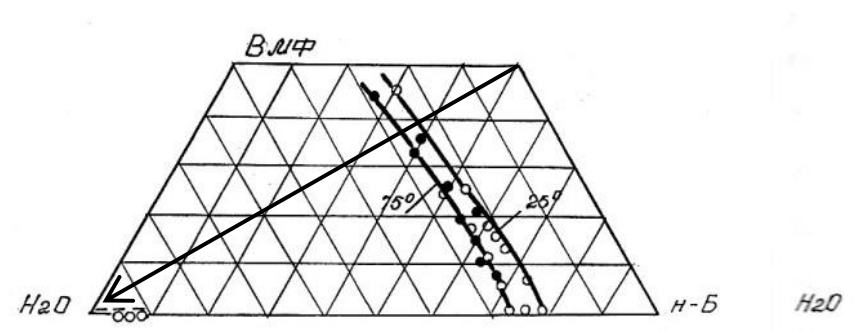

$\mathrm{BM}+{ }_{\mathrm{H}-\mathrm{Б}}$

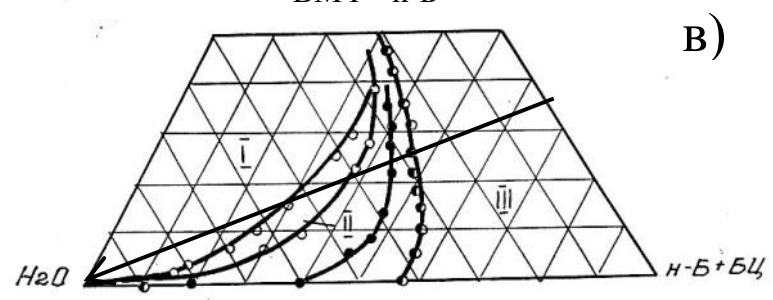

б)

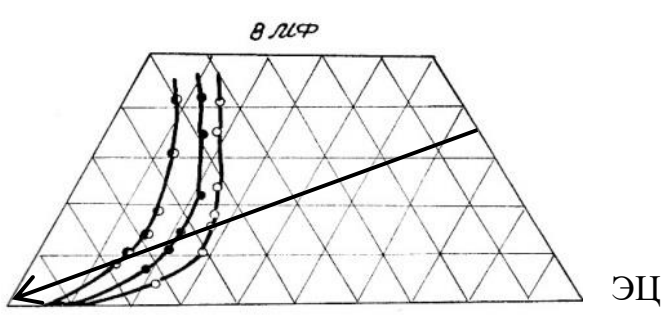

в)

\section{Рис. 2.30. Диаграммы фазовых равновесий при температурах $25,50,75^{\circ} \mathrm{C}$ систем: a) $\mathrm{H}_{2} \mathrm{O}-$ ВМФ-H-Б; б) $\mathrm{H}_{2} \mathrm{O}-$ ВМФ - ЭЦ; в) $\mathrm{H}_{2} \mathrm{O}-$ ВМФ - БЦ}

При добавлении сильного гомогенизатора ЭЦ резко сокращается площадь гетерогенного состояния системы, увеличивается площадь гомогенного стабильного состояния и увеличивается предел разбавления водой до 40\% (рис. 2.30 б). Более слабое гомогенизирующее действие БЦ обусловлено расслоением низкомолекулярной системы $\mathrm{H}_{2} \mathrm{O}-$ БЦ при $50^{\circ} \mathrm{C}$ и усилением высаливающего действия ВМФ на эту систему. Способность разбавлять 50\% -го раствора ВМФ в БЦ водой без нарушения стабильности снижается в два раза при $25^{\circ} \mathrm{C}$ (рис.2.30 в). При повышении температуры до $50^{\circ} \mathrm{C}$ появляется область метастабильного состояния, исчезающая при $75^{\circ} \mathrm{C}$. Повысить стабильность раствора ВМФ в н-бутаноле при разбавлении водой, как показали результаты анализа фазовых равновесий систем $\mathrm{H}_{2} \mathrm{O}-\mathrm{BMФ} \mathrm{-} \mathrm{н-Б,} \mathrm{можно} \mathrm{с} \mathrm{помощью}$ сильного гомогенизатора (ЭЦ) неограниченно совмещающейся с водой во всем диапазоне концентраций при температуре $25 \ldots 75^{\circ} \mathrm{C}$.

Проведенные исследования позволили обосновать гипотезу минимизации летучих компонентов в составе водоразбавляемых ПОС путем использования 


\section{СТАБИЛИЗАЦИЯ СВОЙСТВ ТОПЛИВНО-ЭНЕРГЕТИЧЕСКИХ СИСТЕМ НА ОСНОВЕ ПРИРОДНЫХ И СИНТЕТИЧЕСКИХ ПОЛИМЕРОВ}

эффективного гомогенизатора. Для подтверждения данной гипотезы был выбран роданид аммония - $\mathrm{NH}_{4} \mathrm{CNS}$, который оказывает гомогенизирующее действие на гетерогенную систему $\mathrm{H}_{2} \mathrm{O}-\mathrm{H}-Б$. Анализ диаграммы фазовых равновесий в системе $\mathrm{H}_{2} \mathrm{O}-\mathrm{BM} \Phi+\mathrm{NH}_{4} \mathrm{CNS}-$ н-Б показал, что $\mathrm{NH}_{4} \mathrm{CNS}$ резко увеличивает диапазон стабильного состояния системы, как и в случае с ЭЦ. Гипотеза минимизации летучих компонентов пленкообразующих систем, подтвержденная патентом РФ, гарантирует стабильность меламиноформальдегидной смолы разбавлении водой и безопасность окрасочных цехов, снижение токсичности, пожаро- и взрывоопасности рабочей зоны, выбросов в приземный слой атмосферы [52].

\subsection{4 Влияние фазового состояния на реологию пленкообразующих систем}

В связи с тем, что формирование покрытия водоразбавляемой эмали ВПЭ-1179 протекает при температуре выше $130^{\circ} \mathrm{C}$, то состав, структура и свойства тонкого слоя лакокрасочного покрытия будут отличаться от таковых объемной фазы, из которой образовалось покрытие. Движение сферической формы сольватных молекул ПО из объема жидкости к поверхности металлраствор происходит со скоростью своего слоя. Молекулы более сложной конфигурации способные проникать в соседний слой и взаимодействовать с низкомолекулярными комплексами и препятствуют скольжению соседних слоев. Несовпадение скорости движения сольватных частиц ПО в разных слоях создает возможности для сцепления подвижных сегментов макромолекул пленкообразователя с образованием новых структурных форм и отражением на физико-химические свойства раствора ПОС в объеме жидкости. Моделирование движения реальных тел основывается на использовании классических законов механики, описывающих движение идеальных тел в идеальных средах и отклонений от этих законов при движении реальных тел в реальных средах. Построение конкретных моделей движения частиц реальных 


\section{СТАБИЛИЗАЦИЯ СВОЙСТВ ТОПЛИВНО-ЭНЕРГЕТИЧЕСКИХ СИСТЕМ НА ОСНОВЕ ПРИРОДНЫХ И СИНТЕТИЧЕСКИХ ПОЛИМЕРОВ}

тел сводится к изучению изменений физико-химических или физикомеханических свойств частицы в процессе движения или деформации от времени или состава с учетом свойств и строения среды. Однако поведение многих материалов в реальных условиях не описывается закономерностями, лежащими в основе классических моделей [23, с. 87].

Изучение влияния фазового состояния и межмолекулярных взаимодействий низкомолекулярных компонентов с подвижными сегментами олигоэфира ВПФСинА на реологические свойства в объемной фазе ПОС проводили по изменению кривых вязкости от состава бинарного растворителя $\mathrm{H}_{2} \mathrm{O}$ - БЦ. Концентрация олигоэфира ВПФсинА при этом остается постоянной величиной и соответствует концентрациям: 3, 10, 20, 30\%. Содержание ДМЭА в ПОС также постоянно и соответствует эквивалентной степени нейтрализации карбоксильных групп о чем свидетельствует постоянное значение $\mathrm{pH}=7$ выбранных.

В гомогенной области при $\mathrm{C}_{\text {ВПФСинА }}=3 \%$ с увеличением содержания воды в ПОС вязкость постепенное увеличивается, достигает максимального значения при 30-40\% воды, а затем резко падает при расслоении системы. Аналогичный характер имеет изотерма вязкости при $\mathrm{C}_{\text {ВПФСинА }}=10 \%$ (рис. 2.31a). При более высоких концентрациях олигоэфира ВПФСинА $\left(\mathrm{C}_{\text {ВПФСинА }} 30 \%\right)$ в гомогенных составах вязкость постепенно увеличивается и достигает максимума в области метастабильного состояния, а в гетерогенных составах постепенно снижается. 

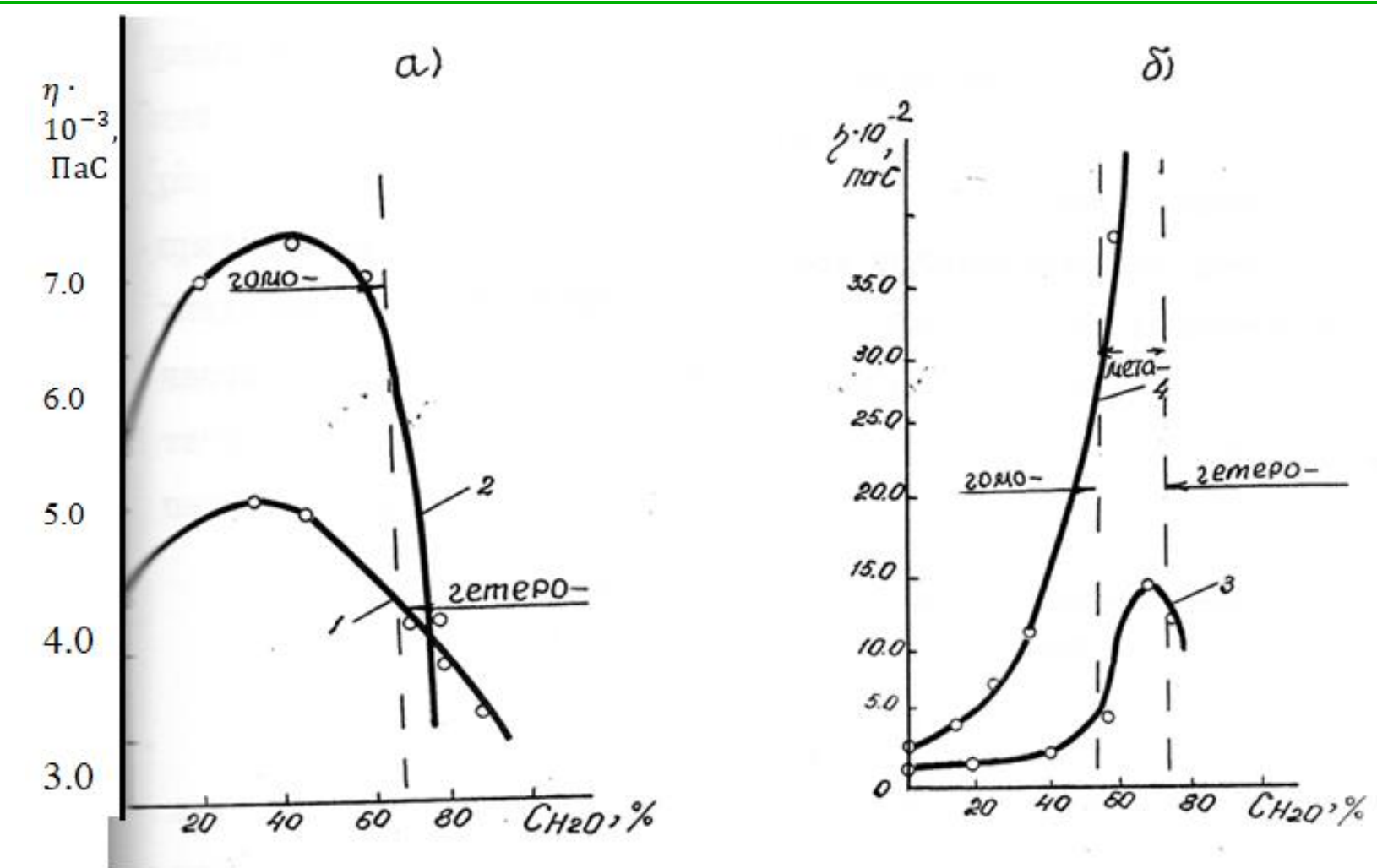

Рис. 2.31. Изменение вязкости от состава бинарной системы $\mathrm{H}_{2} \mathrm{O}$ - БЦ и фазового состояния системы ПОС Н2О - ВПФСинА+ДМЭА - БЦ

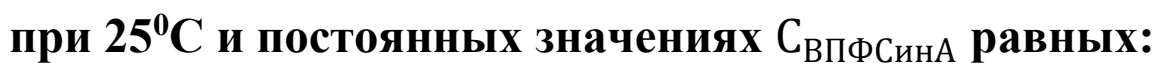

кривая $1-3 \%$, кривая $2-10 \%$, кривая $3-20 \%$, кривая $4-30 \%$

Нарастание вязкости гомогенных составов при разбавлении водой можно связать с перестройкой низкомолекулярных сольватных оболочек макромолекул и изменении ориентации вблизи полярных сегментов макромолекул олигоэфира под действием активных низкомолекулярных комплексов БЦ· $2 \mathrm{H}_{2} \mathrm{O}$. При этом изменяется конформация макромолекул олигоэфира и образуются новые структурные олигомерные ассоциаты. При увеличении содержания воды (>50\%) в пленкообразующей системе происходит переход из гомогенного в гетерогенное состояние и вязкость резко падает. Можно предположить, что в области высоких концентраций воды стабилизируется полимерная структура воды, которая разрушает сольватные олигомерные кластеры. Макромолекулы приобретают более свернутую 


\section{СТАБИЛИЗАЦИЯ СВОЙСТВ ТОПЛИВНО-ЭНЕРГЕТИЧЕСКИХ СИСТЕМ НА ОСНОВЕ ПРИРОДНЫХ И СИНТЕТИЧЕСКИХ ПОЛИМЕРОВ}

конфигурацию, вытесняя низкомолекулярные комплексы в дальнее окружение (прослойку макромолекул). Полученные данные согласуются с кластерной моделью строения водно-органических растворов и объясняют аномальное изменение физико-химических, физико-механических свойств при изменении состава низкомолекулярных веществ вода:ПОР.

Для подтверждения гипотезы о влиянии межмолекулярных взаимодействий и состава низкомолекулярного комплексов: и силами межмолекулярных взаимодействий их с функциональными группами макромолекул пленкообразующего олигоэфира на структуру образующихся и структуру и физико-механические свойства свободных тонких пленок: микротвердости $(\mathrm{H})$; предела прочности при удлинении $(\sigma)$; относительного удлинения (L). Скорость перехода молекул низкомолекулярных компонентов в газовую фазу будет определяться силами межмолекулярных комплексов переменного состава: A $(1 \div 3) \cdot \mathrm{X}$, где $\mathrm{A}$ - молекула амина; X - молекулы воды или органического растворителя. По мере удаления низкомолекулярных веществ будет изменяться структура подвижных сольватов сегментов в объемной фазе:

$$
\left\{\mathrm{R}_{-(\mathrm{OH})_{m}}^{-(\mathrm{COOH})_{n}}: \mathrm{M}_{\mathrm{a}}\right\}: \mathrm{M}_{\mathrm{p}}: \mathrm{M}_{\mathrm{t}} \vdots \mathrm{M}_{\%}
$$

где $R$ - углеводородная часть олигоэфира; $\mathrm{n}$ - число - СООН групп; m - число -ОН групп; $\mathrm{M}_{\mathrm{a}}$ - молекулы амина, находящихся в ближнем окружении; $\mathrm{M}_{\mathrm{p}}$ - молекулы воды, находящихся в дальнем окружении; $\mathrm{M}_{\mathrm{t}}$ - молекулы полярного органического растворителя, находящихся в дальнем окружении; $\mathrm{M}_{ж}$ - число свободных молекул растворителя; : - границы оболочек структурных элементов олигоэфира.

При этом переход в газовую фазу может происходить из гомогенного, гетерогенного или метастабильного состояния ПОС в объемном слое, которое в свою очередь может предопределить структуру формируемого покрытия, его физико-механические и защитные свойства. Поэтому на следующем этапе было 
изучено влияние фазового состояния объемной фазы на свойства свободных пленок. Свободные лаковые пленки получали из гомогенных и гетерогенных составов по ГОСТ $14243-78$ на фторопласте при температуре $130^{\circ} \mathrm{C}$ в течении 45 минут из пленкообразующих систем с суммарным содержанием пленкообразователя (ВПФСинА) и смолы отвердителя (ВМФ) 40\%, постоянном соотношении ВМФ:ВПФСинА=1:3 и варьировании состава бинарной смеси вода:БЦ (рис. 2.32).

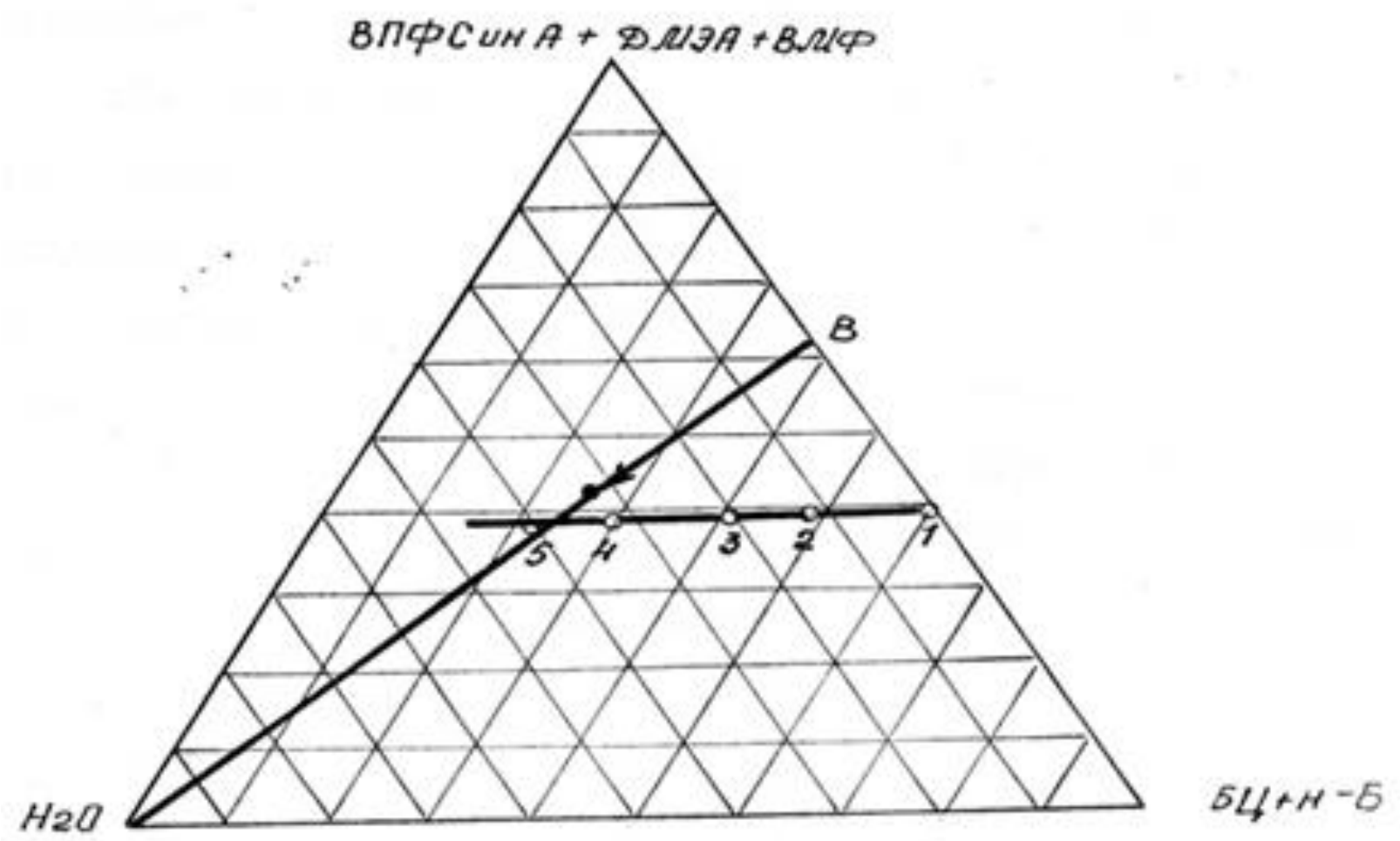

\section{Рис. 2.32. Модель оценки фазового состояния составов \\ Н2 $_{2}$ - ВПФСинА+ДМЭА+ВМФ -БЦ+н-Б для получения свободных пленок}

На модельной диаграмме фазового состояния эти составы находятся на прямой параллельной стороне $\mathrm{H}_{2} \mathrm{O}-$ БЦ+н-Б концентрационного треугольника: составы 1, 2, 3 - гомогенные, а составы 4 и 5 - гетерогенные.

Структуру свободных тонких пленок оценивали по изменению физикомеханических свойств от состава: микротвердости $(\mathrm{H})$ - кривая 1 ; предела прочности при удлинении $(\sigma)$ - кривая 2 ; относительного удлинения 
(L) - кривая 3 (рис. 2.33). При эквивалентной степени нейтрализации физикомеханические свойства (микротвердость, относительное удлинение, предел прочности при удлинении) монотонно убывают (рис. 2.33a). При избыточной степени нейтрализации на кривых свойств имеется ярко выраженный минимум в метастабильной области.

Микротвердость и предел прочности свободных пленок при увеличении содержания воды и приближении к области расслоения системы резко падают, а эластичность пленок изменяется монотонно (рис. 2.33, кривая 2). Электронномикроскопическое исследование свободных пленок позволило определить размер и форму структурных элементов (рис. 2.34). Обнаружено бимодальное распределение частиц в свободных пленках, сформированных из исходных составов 1...5. Преобладают частицы размером 50..60 нм - гомогенные кластеры и «вторичные» сферические частицы - гетерогенные кластеры размером $100 \ldots 500$ нм.

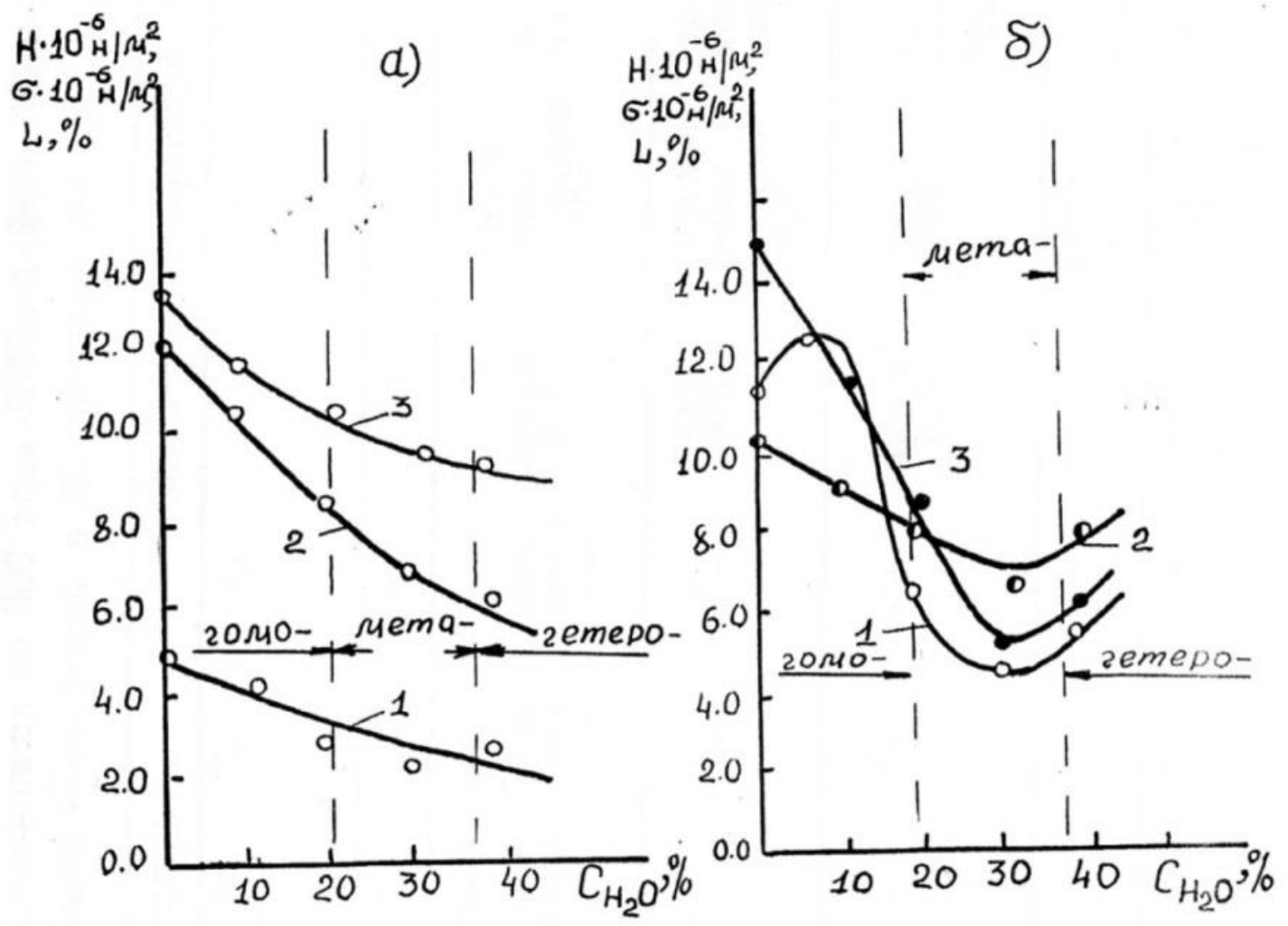

Рис. 2.33. Изменение микротвердости Н (кривая 1), предела прочности при удлинении $\sigma$ (кривая 2), относительного удлинения L (кривая 3) свободных пленок при эквивалентной степени нейтрализации (а) и при избыточной степени нейтрализации (б) 


\section{СТАБИЛИЗАЦИЯ СВОЙСТВ ТОПЛИВНО-ЭНЕРГЕТИЧЕСКИХ СИСТЕМ НА ОСНОВЕ ПРИРОДНЫХ И СИНТЕТИЧЕСКИХ ПОЛИМЕРОВ}

Образование крупных сферических частиц $100 \ldots 500$ нм по всей видимости связано с протеканием реакции поликонденсации между макромолекулами олигоэфира ВПФСинА и смолы отвердителя ВМФ в микроблоках. При испарении низкомолекулярных компонентов макромолекулы олигомера приобретают развернутую конфигурацию, уменьшается расстояние между свободными функциональными группами макромолекул и увеличивается взаимодействие между реакционными группами олигоэфира и смолы отвердителя. Предложена гипотеза стабилизации водоразбавляемых пленкообразующих систем за счет образования в растворе стабильных олигомерных кластеров, сольватированных низкомолекулярными составляющими лакокрасочных материалов. На формирование первичных частиц оказывают влияние полимерные кластеры воды и водно-органические кластеры, которые образуются размещением растворяемых в воде низкомолекулярных комплексов переменного состава в полости полимерного кластера воды с учетом ближних и дальних взаимодействий с окружающими молекулами растворителя и собственного объема для размещения в свободном пространстве растворителя.

a)

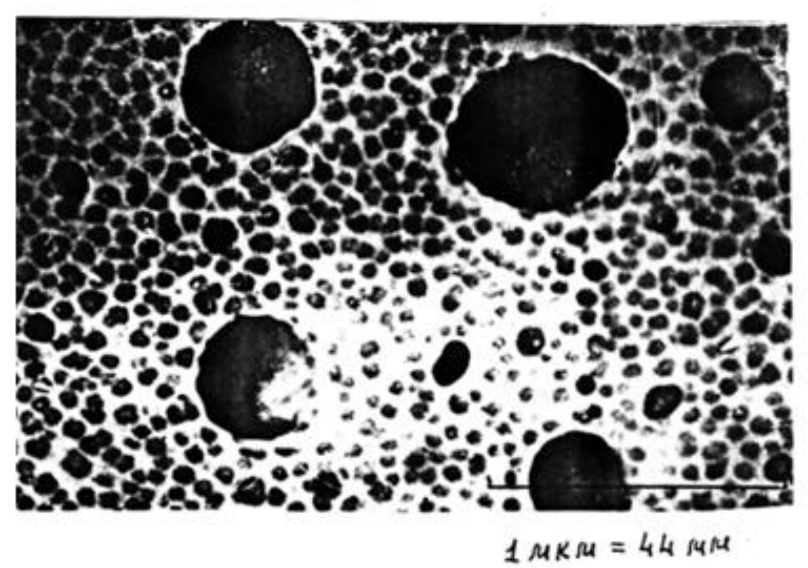

б)

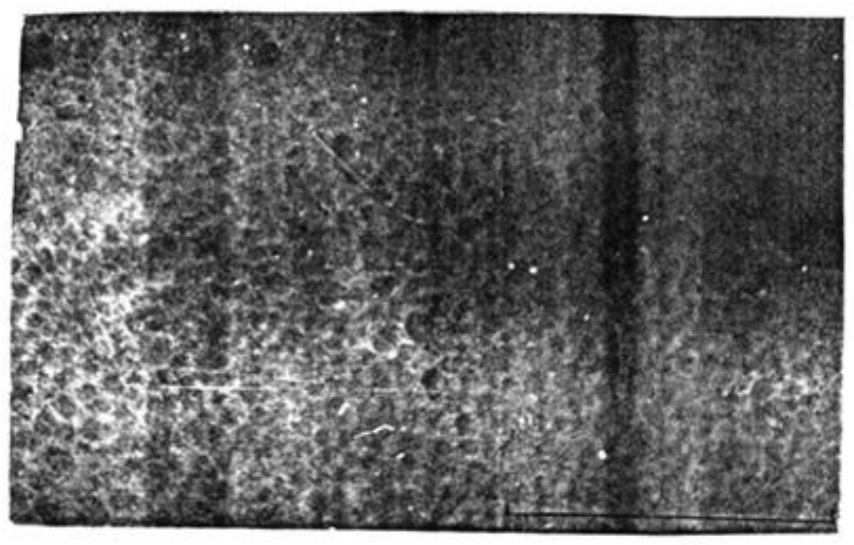

$1 \mu K M=44 \mu \mu$

Рис. 2.34. Структура пленок, сформированных из гомогенных (a) и гетерогенных $40 \%$ составов (б) 


\section{СТАБИЛИЗАЦИЯ СВОЙСТВ ТОПЛИВНО-ЭНЕРГЕТИЧЕСКИХ СИСТЕМ НА ОСНОВЕ ПРИРОДНЫХ И СИНТЕТИЧЕСКИХ ПОЛИМЕРОВ}

Установленная с помощью термодинамических инструментариев качества корреляция межмолекулярных взаимодействий низкомолекулярных компонентов и их гомогенизирующим действием на гетерогенные бинарные системы, позволила, сформулировать и подтвердить гипотезу о роли низкомолекулярных комплексов переменного состава на гомогенизирующий эффект гетерогенных бинарных систем, обосновать выбор эффективного амина для нейтрализации - $\mathrm{COOH}$ групп ПО и определить области стабильного состояния ПОС.

Разработанная методология стабилизации водоразбавляемых пленкообразующих систем и концепция минимизации содержания токсичных, летучих низкомолекулярных веществ в их составе защищены патентом РФ и внедрены при корректировке летучих компонентов рецептур опытнопромышленных партий водоразбавляемых лакокрасочных материалов, выпускаемых на Торжокском заводе полиграфических красок и ЛНПО «ПИГМЕНТ». Снижение содержания, органических растворителей позволило гарантировать качество и воспроизводство физико-химических, физико-механических лакокрасочных материалов и защитных свойств покрытий, повысить безопасность: пожаро- и взрывоопасность окрасочных цехов, минимизировать содержание токсичных веществ в промышленных выбросах, энергетические затраты при изготовлении и нанесении данных материалов на изделие расширяет возможности прогнозирования стабильности качества полимерных систем. 


\section{ГЛАВА 3. \\ МЕТОДОЛОГИЯ ОЦЕНКИ КАЧЕСТВА АТМОСФЕРНОГО ВОЗДУХА ТЕХНОГЕННЫХ СИСТЕМ}

\section{1 Физико-химические инструментарии стабильности экосистем}

Стабильное функционирование техногенных систем основано на единстве физических и химических и биологических процессов: горение, грозовые разряды, гниение, фотосинтез. Природные экосистемы, функционируя по экологическим законам, обмениваясь веществом и энергией в процессе круговорота биогенных элементов на молекулярном, клеточном, тканевом, популяционном, биоценотическом уровнях существования живого вещества с образованием устойчивых связей между живой и неживой частью экосистемы, регулирующих динамическое равновесие экосистемы - гомеостаз. При отклонении экологических факторов от оптимальных значений равновесие в экосистеме нарушается и устанавливается при новых условиях в течение определенного промежутка времени за счет адаптации живых организмов. Способность экосистемы поддерживать гомеостаз определяет ее стабильность. Стабильное функционирование техногенных систем во многом определяется качеством атмосферного воздуха, необходимого для дыхания живых организмов. Живое вещество в атмосфере (пыльца, споры) находится в виде дисперсных систем: суспензий, эмульсий, аэрозолей (пыль, дым, туман), стабильность которых связана с кинетическими параметрами взаимодействия частиц - расстоянием друг от друга и от поверхности контакта, временем свободного пробега. В этом случае по теории ДЛФО (Дерягина, Ландау, Фервея, Овербека) критерием устойчивости является соотношение энергетического барьера и энергии броуновского движения частиц. Высота энергетического барьера является основным критическим параметром, 


\section{СТАБИЛИЗАЦИЯ СВОЙСТВ ТОПЛИВНО-ЭНЕРГЕТИЧЕСКИХ СИСТЕМ НА ОСНОВЕ ПРИРОДНЫХ И СИНТЕТИЧЕСКИХ ПОЛИМЕРОВ}

определяющим их поведение. Выведение частиц из атмосферного воздуха происходит при седиментации - сухого осаждения или слипания - коагуляции твердых частиц [53], коалесценсии - слияния жидких частиц, кристаллизации формировании зародыша новой фазы, центра кристаллизации с атмосферными осадками в объекты экосистемы, с последующей миграцией, трансформацией аккумуляцией в отходах. Скорость седиментации - оседание частиц под действием силы тяжести, пропорциональна приблизительно квадрату размера частиц и составляет нескольких десятков см/с для частиц размером 100 мкм, нескольких мм/с для частиц в 10 мкм и чрезвычайно мала для частиц меньше 1 мкм. Броуновское движение частиц - хаотичное, тепловое, равновесное делается заметным лишь в случае частиц меньше 1 мкм. Под действием броуновского движения частицы осаждаются на любых поверхностях, с которыми аэрозоли соприкасаются. Коагуляция частиц в аэрозолях происходит при столкновениях между частицами либо в результате броуновского движения, неодинаковой скорости седиментации, влияния электростатических сил и пр. Твёрдые частицы слипаются (коагуляция) при столкновениях, а жидкие сливаются (коалесценсия), и число свободно движущихся частиц уменьшается. Скорость коагуляции, т.е. уменьшение числа частиц в единицу времени, пропорциональна квадрату их концентрации. Поэтому при концентрации частиц $10^{10}$ в см$^{3}$ частицы оседают за 0,7 секунд, а при концентрации $10^{6}$ в $\mathrm{cm}^{3}-$ за 12 минут.

Распределение загрязняющих веществ в атмосфере зависит от природной зоны, размещения производственно-промышленных комплексов, типа воздействия (основного, смешенного, сопутствующего) и характера удаления токсичных отходов (поверхностное складирование, подземное захоронение, сброс в море, мировой океан и т.д.), продолжительности и вида воздействия. Особую опасность для окружающей среды представляют пространственнораспределенные загрязнения (рис. 3.1) передвижных источников (автомобильный транспорт), лесных пожаров, извержений вулканов, обработки 


\section{СТАБИЛИЗАЦИЯ СВОЙСТВ ТОПЛИВНО-ЭНЕРГЕТИЧЕСКИХ СИСТЕМ НА ОСНОВЕ ПРИРОДНЫХ И СИНТЕТИЧЕСКИХ ПОЛИМЕРОВ}

хлор и фосфор содержащими пестицидами больших массивов для борьбы с вредителями, болезнями и сорными растениями. С одной стороны, они загрязняют большие территории, а с другой стороны, их трудно обнаружить, пока они себя не проявятся в виде кислотных дождей, фотохимического смога. Газообразные выбросы: диоксид углерода $\mathrm{CO}_{2}$, закись азота или «веселящий газ» $-\mathrm{N}_{2} \mathrm{O}$, диоксид серы $-\mathrm{SO}_{2}$, оксид углерода $-\mathrm{CO}$, оксиды азота $\mathrm{NO}_{\mathrm{x}}$ участвуют в фотохимических реакциях с образованием озона в приземном слое атмосферы и поглощая инфро-красные лучи создают парниковый эффект.

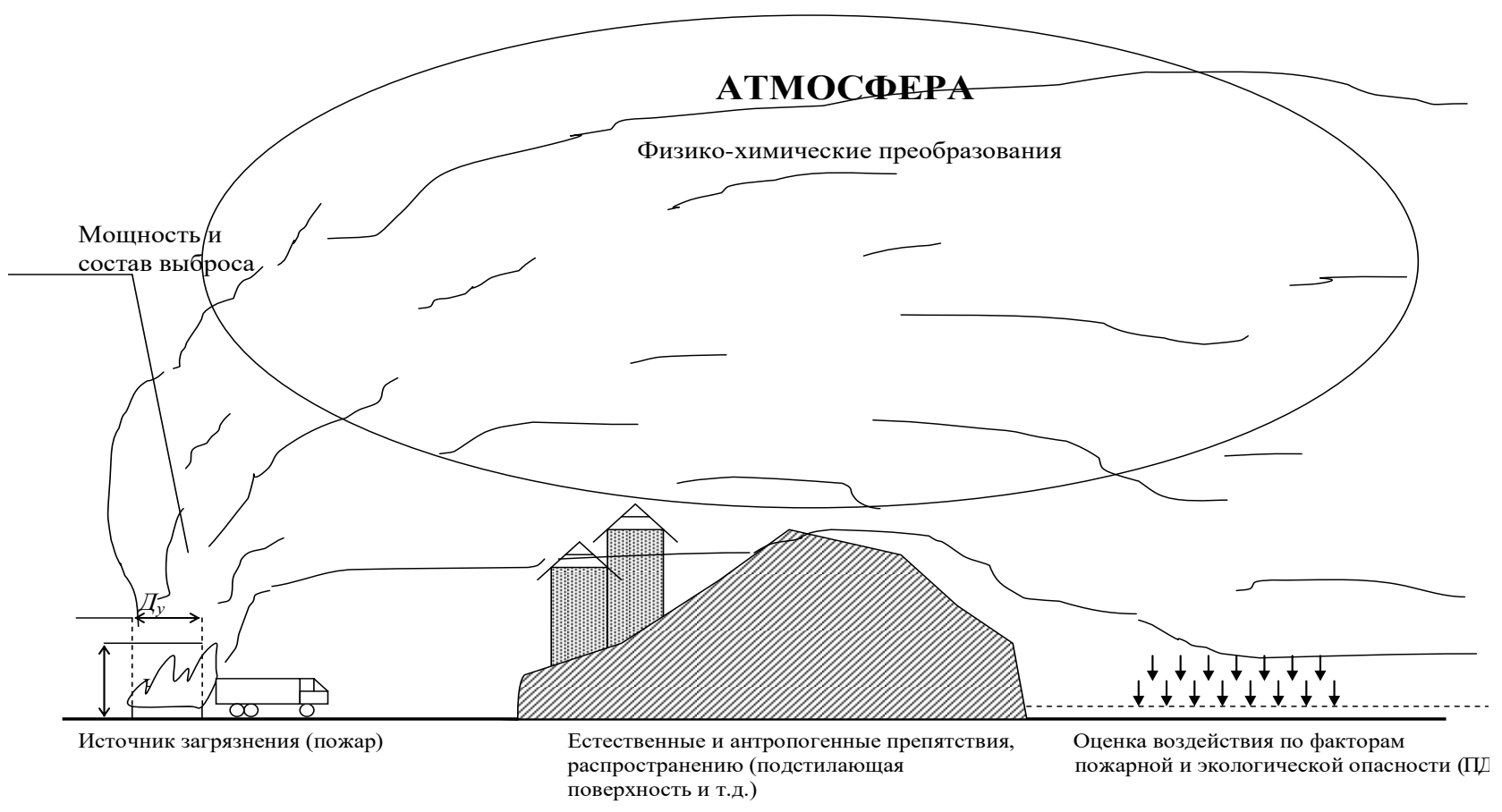

Рис. 3.1. Схема распределения газообразных загрязняющих веществ

Поступающие из различных источников загрязняющие вещества переносятся воздушными и водными потоками и распределяются под влиянием их турбулентного перемешивания. В случае атмосферных переносов примеси перемещаются не только по горизонтали, но и по вертикали. Интенсивность этих выпадений зависит от турбулентности течения воздуха, при котором частицы совершают движение по сложным траекториям; в зависимости от 


\section{СТАБИЛИЗАЦИЯ СВОЙСТВ ТОПЛИВНО-ЭНЕРГЕТИЧЕСКИХ СИСТЕМ НА ОСНОВЕ ПРИРОДНЫХ И СИНТЕТИЧЕСКИХ ПОЛИМЕРОВ}

рельефа местности и характера подстилающей поверхности. При средней скорости западных воздушных потоков (30.. 35 м/с) в верхних слоях атмосферы, наблюдаемой в умеренных широтах, аэрозольные выбросы успевают обогнуть земной шар за $10 \ldots 12$ суток. Переносы в вертикальном направлении осуществляются медленнее, чем в горизонтальном направлении. Важнейшие свойства аэрозолей - способность частиц сохраняться во взвешенном состоянии, перемещаться преимущественно как единое целое и при столкновении прилипать друг к другу или к какой-либо поверхности с вероятностью равной единице [54]. В покоящейся среде частицы аэрозолей поддерживаются во взвешенном состоянии в поле гравитации благодаря их собственному тепловому движению, энергия которого для частиц любой массы равна

$$
E=3 / 2 k T,
$$

где $k$ - постоянная Больцмана, Т - абсолютная температура вследствие обмена энергией с молекулами среды.

Распределение частиц по высоте обычно характеризуют параметром $H_{p}$ - Перреновская высота, рассчитанного по формуле

$$
H_{p}=\frac{k T}{m g},
$$

где $\mathrm{g}$ - ускорение силы тяжести, $\mathrm{m}$ - масса частицы.

Для достаточно малых частиц, когда $H_{p}$ намного превосходит их линейный размер $H_{p} \gg r$, энергии теплового движения достаточно для поддержания частиц во взвешенном состоянии. Если же размер частиц сравним с параметром $H_{p}\left(r \approx H_{p}\right)$ или больше него $r \geq H_{p}$, то для поддержания частиц во взвешенном состоянии необходима энергия, получаемая при соударениях с молекулами дисперсионной среды (ДС), то есть воздуха. Скорость движения частиц определяется внешней силой и силой сопротивления среды движению частиц. В большинстве случаев эти силы уравновешивают друг друга, и частицы движутся $\mathrm{c}$ постоянной скоростью. В средах $\mathrm{c}$ сильной 
турбулентностью и в акустических полях частицы движутся с ускорением. Отношение скорости $v$ стационарного движения частицы к действующей на нее силе называется подвижностью частицы $B$.

Процессы переноса описываются уравнениями, конечный вид которых зависит от числа Кнудсена $K n$

$$
K n=\frac{l}{d},
$$

где $l$ - длина свободного пробега газовых молекул, $d$ - диаметр частицы дисперсной фазы (ДФ) аэрозоля.

При $K n \ll l, d_{p} \gg l$ дисперсионная среда может рассматриваться как сплошная, в этом случае говорят о континуальном режиме процессов переноса.

В континуальном режиме рассчитывают подвижность частицы $B$ по формуле Стокса

$$
\mathrm{B}=\left(3 \pi d_{p} \eta v\right)^{-1},
$$

где $\eta$ - вязкость среды.

Эта формула позволяет рассчитывать подвижность $B$ с точностью до $10 \%$ при $K n>0,1$ и числе Рейнольдса $R e<0,6$. При больших $R e$ вводят поправочные множители, являющиеся функциями $R e$.

В области $1<K n<0,1$ в формулу Стокса вводят поправочный множитель Кеннингема, равный

$$
1+A_{1} K n,
$$

где $A_{l}$ - эмпирическая постоянная.

В свободномолекулярном режиме при $K n>10$ подвижность равна

$$
B=A_{1}+Q / 3
$$

- формула Эпштейна, где $Q$ - эмпирическая постоянная.

В переходном режиме для расчета $B$ предложен ряд эмпирических формул, из которых наиболее распространена формула Милликена

$$
\mathrm{B}=\left[1+\mathrm{A}_{1} \mathrm{~K} n+Q \cdot \mathrm{K} n \exp ^{(-b / \kappa n)}\right] 3 \pi \eta d_{\mathrm{p}},
$$

где $b$ - эмпирическая постоянная. 


\section{СТАБИЛИЗАЦИЯ СВОЙСТВ ТОПЛИВНО-ЭНЕРГЕТИЧЕСКИХ СИСТЕМ НА ОСНОВЕ ПРИРОДНЫХ И СИНТЕТИЧЕСКИХ ПОЛИМЕРОВ}

Значение $B$ позволяет определить коэффициент тепловой броуновской диффузии частиц

$$
D=k T B .
$$

Если $K n>>1$, то аэрозоль можно рассматривать как смесь двух газов, молекулы одного из которых - частицы аэрозоля, намного тяжелее молекул дисперсионной среды. В такой системе процессы переноса описываются с помощью уравнений газокинетической теории (свободномолекулярный режим).

При $K n \approx 1$ (диаметр частиц при атмосферном давлении равен $0,01 \ldots 1,0$ мкм) процессы переноса рассчитываются приближенными методами динамики разреженных газов (переходный режим). Точность уравнений, описывающих процессы переноса в свободномолекулярном и континуальном режимах на границах указанного интервала размера частиц, определяющего значения $K n$, составляет $10 \%$.

На процессы переноса в аэрозолях влияет движение частиц относительно среды под действием внешних сил или сил инерции; оно характеризуется числом Маха

$$
M=u_{p} / u_{\partial}
$$

где $u_{p}$ - скорость частиц относительно среды, $u_{\partial}$ - скорость теплового движения молекул среды. При анализе характера переноса импульса вместо числа Маха часто используют число Рейнольдса

$$
R e=4 M / K n .
$$

Частицы аэрозолей размером менее 1 мкм всегда прилипают к твердым поверхностям при столкновении с ними. Столкновение частиц друг с другом при броуновском (тепловом) движении приводит к коагуляции. Для монодисперсных аэрозолей со сферическими частицами скорость коагуляции равна

$$
d n / d t=-K n^{2},
$$




\section{СТАБИЛИЗАЦИЯ СВОЙСТВ ТОПЛИВНО-ЭНЕРГЕТИЧЕСКИХ СИСТЕМ НА ОСНОВЕ ПРИРОДНЫХ И СИНТЕТИЧЕСКИХ ПОЛИМЕРОВ}

где $n$ - число частиц в единице объема, $K$ - коэффициент броуновской коагуляции.

В континуальном режиме $K$ рассчитывают по формуле Смолуховского

$$
K=4 \pi d_{p} D_{p},
$$

в свободномолекулярном - по формуле

$$
\kappa=\pi \sqrt{2} d_{p}^{2} u_{p} \beta,
$$

где $u_{p}$ - средняя скорость теплового движения аэрозольных частиц, $\beta$ - коэффициент, учитывающий влияние межмолекулярных сил и для различных веществ имеющий значение от 1,5 до 4.

Для переходного режима точных формул для вычисления $K$ не существует.

Помимо броуновского движения коагуляция аэрозолей может иметь и другие причины: градиентная коагуляция обусловлена разностью скоростей частиц в сдвиговом потоке; кинематическая - различной скоростью движения частиц относительно среды (например, в поле гравитации); турбулентная и акустическая обусловлены тем, что частицы разного размера сближаются и сталкиваются, будучи в разной степени увлечены пульсациями или звуковыми колебаниями среды (последние две причины существенны для инерции частиц размером не менее $10^{-6}$ м). На скорость коагуляции влияет наличие электрического заряда на частицах и внешнего электрического поля.

Основными источниками загрязнения атмосферного воздуха при неполном сгорании углеводородного топлива ДВС и тепловых электростанций

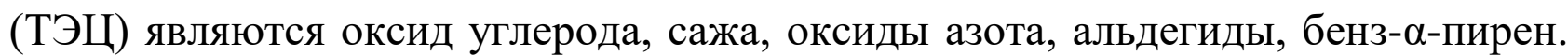
Приоритетными показателям качества и безопасности глобального мониторинга является регулярные наблюдения за содержанием и распределением в атмосферном воздухе чрезвычайно опасных загрязнителей (1-й класс опасности), например, нитрозоамины или бенз- $\alpha$-пирен (рис.3.2). 


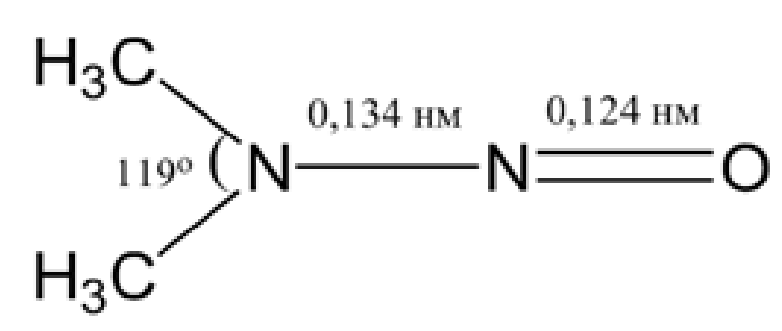

Нитрозоамин

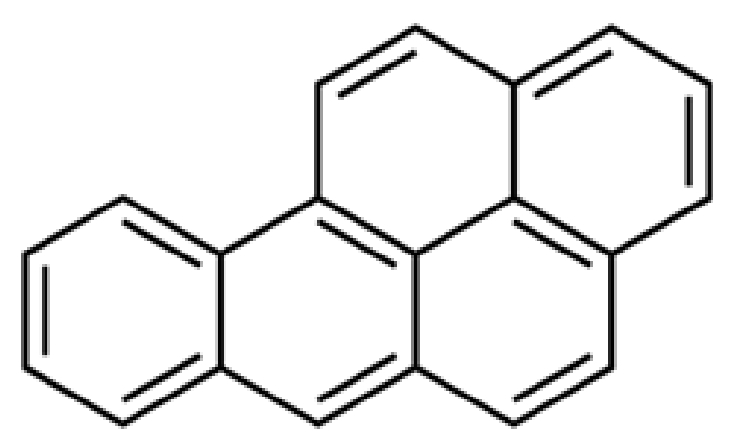

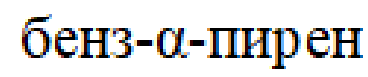

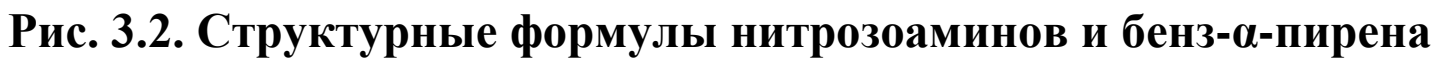

Нирозоамины, образуясь при биохимической трансформации оксидов азота (2 класс опасности) в биологических объектах обладают канцерогенным действием, окисляя железо $\left(\mathrm{Fe}^{+2}\right)$ гемоглобина в железо $\left(\mathrm{Fe}^{+3}\right)$. При этом нарушается состав эритроцитов крови и транспортировка кислорода ко всем элементам организма и при 80\%-м окислении наступает гибель теплокровных организмов. При растворении оксидов азота в воде образуются нитрит ион $\mathrm{NO}_{2}{ }^{-}$, способный при взаимодействии с аминокислотой изменять ее структуру

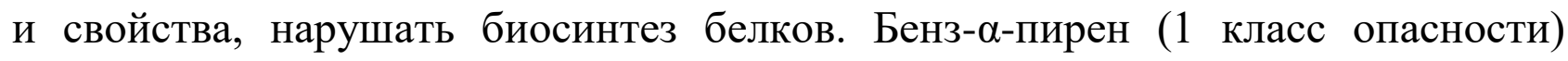
относится к полициклическим углеводородам также обладает канцерогенным действием для теплокровных организмов, адсорбируясь на частицах сажи, выпадает из атмосферного воздуха и накапливается в поверхностном слое почвы. С помощью рентгеноструктурного анализа, электронной микроскопии было установлено, что сажа, образующаяся при сгорании углеводородного жидкого топлива в ДВС имеет аморфную структуру с размером частиц 0,2 мкм [55]. Под действием квантов света молекулярный кислород и оксиды азота, которые накапливаются в атмосфере во время устойчивой безветренной погоды, поглощают энергию ультрафиолетового излучения Солнца, переходят в возбужденное электронное состояние, инициируя фотохимические реакции с образованием в нижних слоях атмосферы озона $\mathrm{O}_{3}$ : 


$$
\begin{gathered}
\mathrm{NO}_{2}+\mathrm{hv} \rightarrow \mathrm{NO}+\mathrm{O}^{*} \\
\mathrm{O}_{2}+\mathrm{O}^{*}+\mathrm{hv} \leftrightarrow \mathrm{O}_{3} \\
\mathrm{NO}_{2}+\mathrm{O}^{*} \rightarrow \mathrm{NO}+\mathrm{O}_{2} \\
\mathrm{NO}+\mathrm{O}_{3} \rightarrow \mathrm{NO}_{2}+\mathrm{O}_{2} \\
\mathrm{O}_{3}+\mathrm{H}_{2} \mathrm{~S}=\mathrm{S} \mathrm{O}_{2}+\mathrm{H}_{2} \mathrm{O} \\
\mathrm{O}_{3}+\mathrm{H}_{2}=\mathrm{H}_{2} \mathrm{O}+\mathrm{O}_{2}
\end{gathered}
$$

Под влиянием фотохимического смога у растений набухают листья, затем на верхней части листовой пластины появляются пятна или белый налет, а на нижней появляется бронзовый или серебристый оттенок. При длительном воздействии озона растение быстро увядает и гибнет.

На полноту сгорания углеводородов в ДВС влияют фракционный состав топлива, температура и способ подачи топлива и воздуха в камеру и другие факторов. С увеличением доли высококипящей фракции углеводородов снижается полнота сгорания топлива. С помощью инструментариев хроматографии определен состав углеводородов, образующихся при термической деструкции топлива и показаны возможные пути образования бенз- $\alpha$-пирена и оксидов азота по цепному механизму [56, с. $36 ; 57$, с. 14].

Отработавшие газы (ОГ) выбрасываемы в окружающую среду при работе разомкнутого цикла ДВС - это гетерогенная смесь различных веществ с разнообразными химическими, физическими свойствами. Количественный состав и нормы содержания вредных выбросов ОГ ДВС различного назначения приведены в таблице 3.1 . 
Таблица 3.1

Основные характеристики вредных выбросов отработавших газов тепловых двигателей

\begin{tabular}{|c|c|c|c|c|c|}
\hline \multirow[b]{2}{*}{$\begin{array}{c}\text { Составляющие } \\
\text { отработавших газов }\end{array}$} & \multirow{2}{*}{$\begin{array}{l}\text { Концент- } \\
\text { рация в ОГ }\end{array}$} & \multirow{2}{*}{$\begin{array}{l}\text { Класс } \\
\text { опас- } \\
\text { ности }\end{array}$} & \multicolumn{3}{|c|}{ ПДК, мг $/ \mathrm{M}^{3}$} \\
\hline & & & $\begin{array}{c}\text { В } \\
\text { рабочей } \\
\text { зоне }\end{array}$ & $\begin{array}{l}\text { Макси- } \\
\text { мально- } \\
\text { разовая }\end{array}$ & $\begin{array}{l}\text { Средне- } \\
\text { суточная }\end{array}$ \\
\hline Окись углерода, \% & $0,01 \ldots 0,5$ & 4 & 20 & 3 & 1 \\
\hline $\begin{array}{l}\text { Окислы азота в } \\
\left.\text { пересчете на } \mathrm{NO}_{2}\right), \%\end{array}$ & $0,005 \ldots 0,5$ & 2 & 5 & 0,085 & 0,085 \\
\hline $\begin{array}{l}\text { Углеводород (в пере- } \\
\text { счете на метан), \% }\end{array}$ & $0,001-0,07$ & $2-4$ & $5-300$ & $1,4-200$ & $1-2,5$ \\
\hline 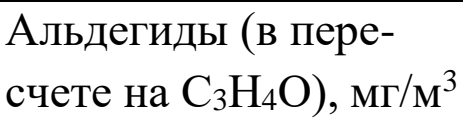 & $1-10$ & $2-3$ & $0,2-5$ & $0,01-3$ & $0,01-5$ \\
\hline Формальдегиды, \% & 0,002 & 3 & 0,5 & 0,035 & 0,003 \\
\hline Акролеин, \% & 0,0001 & 2 & 0,2 & 0,03 & 0,03 \\
\hline Бенз- $\alpha$-пирен, мг $/ \mathrm{m}^{3}$ & $0,5-1$ & 1 & 0,00015 & - & $1 \cdot 10^{-6}$ \\
\hline 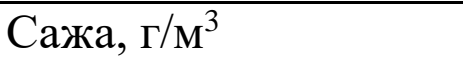 & $0,01-1$ & 3 & 4 & 0,15 & 0,05 \\
\hline
\end{tabular}

Основная масса вредных компонентов ОГ ( $98 \%$ \%) газообразная и состоит из оксидов углерода, оксидов азота и серы, углеводородов. Остальная часть вредных веществ ( 2 \% ОГ) выделяется в виде твердой фазы, на которой адсорбируется более 300 токсичных веществ и жидкой фазы. Твердая фаза представлена в основном в виде сажи и в меньшей степени минеральными частицами из воздуха (пыль) и топлива (зольные составляющие), а также металлическими частицами, образовавшимися в процессе износа пар трения.

Основу жидкой фазы составляют исходные и частично окисленные углеводороды топлива и масла. Часть этих выбросов связана с работой газовых котельных. Поэтому снижение выбросов $\mathrm{NO}_{\mathrm{x}}$ в атмосферу остается первостепенной задачей для техносферной безопасности. 


\section{2 Термодинамические инструментарии стабильности экосистем}

Распределение солнечной энергии в природных экосистемах (макросистемах) описывается законом однонаправленного изменения энергии. При этом большая часть полученной растениями солнечной энергии рассеивается в виде тепла (90\%) и лишь 10\% преобразуется во внутреннюю энергию (энергию химических связей биополимеров), которая в свою очередь передается по трофическим цепям, уменьшаясь в каждом звене. Равновесное состояние химических макросистем описывается с помощью трех основных законах классической термодинамики, которые объясняют законы химических и фазовых равновесий, тепловые эффекты химических реакций и определяет возможности и направление протекания химической реакции. Согласно закону сохранения энергии, энергия не исчезает и не возникает из ничего. Она лишь переходит их одной формы в другую. Количественной мерой этого закона является первый закон термодинамики в применении к процессам, связанным с превращением теплоты и работы, и выражается математическими уравнениями

$$
\begin{gathered}
\mathrm{Q}=\Delta \mathrm{U}+\mathrm{L}, \\
\delta \mathrm{Q}=\mathrm{dU}+\delta \mathrm{L},
\end{gathered}
$$

где $\mathrm{U}$ - внутренняя энергия (общий запас энергии системы); Q - теплота энергия, переданная от одного тела к другому в результате хаотичного движения частиц; $\mathrm{L}$ - работа - энергия, переданная от одного тела к другому в результате направленного движения частиц; $\Delta \mathrm{U}-$ изменение внутренней энергии; $\delta \mathrm{Q}$ - бесконечно малое изменение теплоты; $\delta \mathrm{L}$ - бесконечно малое изменение работы. Согласно выражению 3.12 теплота, переданная системе, расходуется на увеличение внутренней энергии системы $(\Delta \mathrm{U})$ и на совершение работы (L) системой против внешних сил. При бесконечно малом изменении теплоты, согласно уравнению 3.13 , внутренняя энергия становится функцией состояния и не зависит от способа передачи энергии (dU). 
По первому закону термодинамики, разность элементарных количеств теплоты $d Q$ и произведенной системой работой $d L n$ редставляет собой полный дифференциал функции состояния системы - внутренней энергии $\mathrm{dU}$

$$
\mathrm{dQ}-\mathrm{dL}=\mathrm{dU} \text {. }
$$

С другой стороны, первый закон термодинамики можно записать через разность $d Q-d L^{\prime}$, где $d L^{\prime}-$ полезная внешняя работа, и эта разность также есть полный дифференциал функции - энтальпии $\mathrm{H}$ тепловой функции или теплосодержания системы $\mathrm{dH}$

$$
\mathrm{dQ}-\mathrm{dL}^{\prime}=\mathrm{dH}
$$

Применяя I-й закон термодинамики к различным термодинамическим процессам и химическим реакциям, можно рассчитывать тепловые балансы и в направление, в котором они будут протекать [58, с. 200].

При изохорном процессе ( $\mathrm{T}=\mathrm{const}$ и $\mathrm{V}=\mathrm{const})$ выражения 3.12 и 3.13 примут вид

$$
\begin{gathered}
\mathrm{Q}=\Delta \mathrm{U}+\mathrm{PV} \\
\mathrm{Q}_{\mathrm{v}}=\Delta \mathrm{U}=\mathrm{U}_{\mathrm{K}}-\mathrm{U}_{\mathrm{H}} \\
\delta \mathrm{Q}_{\mathrm{v}}=\mathrm{dU}+\mathrm{PdV},
\end{gathered}
$$

где $\mathrm{P}$ - давление, V - объем, PV - работа против внешних сил. Теплота при этих условиях приобретет свойства функции состояния

$$
\delta \mathrm{Q}_{\mathrm{v}}=\mathrm{dU} .
$$

При изобарном процессе $(\mathrm{T}=$ const и $\mathrm{P}=\mathrm{const})$ математическую запись первого закона можно представить в виде уравнения

$$
\delta \mathrm{Q}=\mathrm{dU}+\mathrm{d}(\mathrm{PV})=\mathrm{dU}+\mathrm{P} \mathrm{dV}+\mathrm{V} \mathrm{dP} .
$$

При заданных термодинамических параметрах и $\mathrm{dP}=0$ можно записать

$$
\begin{gathered}
\mathrm{Q}_{\mathrm{p}}=\Delta \mathrm{U}+\mathrm{PV} \\
\delta \mathrm{Q}_{\mathrm{p}}=\mathrm{dU}+\mathrm{PdV} \\
\mathrm{Q}_{\mathrm{p}}=\Delta \mathrm{H}=\mathrm{H}_{\mathrm{K}}-\mathrm{H}_{\mathrm{H}} \\
\delta \mathrm{Q}_{\mathrm{p}}=\mathrm{dH},
\end{gathered}
$$

где $\mathrm{H}=(\mathrm{U}+\mathrm{PV})-$ энтальпия. 


\section{СТАБИЛИЗАЦИЯ СВОЙСТВ ТОПЛИВНО-ЭНЕРГЕТИЧЕСКИХ СИСТЕМ НА ОСНОВЕ ПРИРОДНЫХ И СИНТЕТИЧЕСКИХ ПОЛИМЕРОВ}

Выражения 3.19 - 3.22 являются математической записью закона Гесса, согласно которому теплота $\left(\mathrm{Q}_{\mathrm{v}}\right.$ и $\left.\mathrm{Q}_{\mathrm{p}}\right)$ приобретает свойства функции состояния (не зависит от пути процесса, а зависит только от начального и конечного состояния) при постоянных параметрах системы объема (V) и температуры (T) - изменение внутренней энергии $(\Delta \mathrm{U})$, а при постоянных давлении (Р) и температуры $(\mathrm{T})$ - изменение энтальпии $(\Delta \mathrm{H})$.

Следствия закона Гесса позволяют рассчитать тепловые эффекты химических реакций и термодинамических процессов как разность алгебраических сумм тепловых эффектов, образования продуктов реакции и исходных веществ с учетом стехиометрических коэффициентов без учета промежуточных тепловых эффектов, которые нельзя измерить, используя уравнение

$$
\Delta \mathrm{H}_{\text {x.p. }}=\sum \mathrm{n} \Delta \mathrm{H}_{\text {npod. }}^{o \sigma p .}-\sum \mathrm{n} \Delta \mathrm{H}_{u c x .}^{o \sigma p .} .
$$

Второй закон химической термодинамики устанавливает критерий протекания самопроизвольного процесса в изолированной системе (нет обмена энергией и веществом). Впервые сформулирован Клаузисом - невозможен самопроизвольный переход теплоты от холодного тела к горячему. Физический смысл второго закона термодинамики состоит в том, что любой самопроизвольный процесс протекает в направлении, при котором система из менее вероятного состояния переходит в более вероятное состояние. В ходе самопроизвольного процесса система приближается к такому состоянию, из которого она самопроизвольно выйти не может - состоянию равновесия. Из этого состояния она может выйти лишь при внешнем воздействии.

Самопроизвольный процесс изменения состояния системы возможен при увеличении неупорядоченности - энтропии системы

$$
\mathrm{S}=\mathrm{k} \ln \mathrm{W},
$$

где $\mathrm{k}$ - постоянная Больцмана, $\mathrm{S}$ - энтропия, $\mathrm{W}$ - вероятность.

Для обратимых химических процессов энтропия - функция состояния 


$$
\begin{aligned}
& \mathrm{dS}=0 \quad \Delta \mathrm{S}=\mathrm{S}_{\mathrm{K}}-\mathrm{S}_{\mathrm{H}}, \\
& \Delta \mathrm{S}_{\text {x.p. }}=\sum \mathrm{n} \Delta \mathrm{S}_{\substack{\text { nopod. } \\
\text { ofp. }}}-\sum \mathrm{n} \Delta \mathrm{S}_{u c x \text {. }}^{o \sigma p .} .
\end{aligned}
$$

Термодинамические и химические потенциалы (функции) были введены Гиббсом и Гельмгольцем и нашли применение в учении о равновесии. Для описания самопроизвольных изохорно-изотермических процессов ( $\mathrm{T}=$ const, $\mathrm{V}=$ const) используют функцию Гельмгольца (F), а для изобарноизотермических процессов $(\mathrm{T}=$ const и $\mathrm{P}=\mathrm{const})-$ функцию Гиббса $(\mathrm{G})$ :

$$
\begin{gathered}
\mathrm{dF}=\mathrm{dU}-\mathrm{Td} S \\
\Delta \mathrm{F}=\Delta \mathrm{U}-\mathrm{T} \Delta \mathrm{S} \\
\mathrm{dG}=\mathrm{dH}-\mathrm{Td} S \\
\Delta \mathrm{G}=\Delta \mathrm{H}-\mathrm{T} \Delta \mathrm{S}
\end{gathered}
$$

Изменение функции Гиббса при образовании раствора определяется как разность между функции Гиббса раствора $\left(\mathrm{G}_{\mathrm{pa-pa}}\right)$ и суммарной функции Гиббса исходных компонентов $\left(\mathrm{G}_{\text {исх. }}\right)$.

\section{3 Моделирование образования продуктов деструкции жидкого углеводородного топлива}

Применение законов статической термодинамики позволяет объяснить образование возбужденных частиц и молекул при высоких скоростях движения и столкновении. В возбужденном состоянии за счет перераспределения электронной плотности меняется ориентация молекул, и они в пространстве образуют активные комплексы или радикалы, которые существуют непродолжительный период времени. В этом состоянии комплексы имеют максимальную внутреннюю энергию, энергию активации и являются вновь образовавшимися фазами с избыточными поверхностными силами. Стабильность активного комплекса зависит от прочности образовавшихся связей, а сами комплексы ускоряют или замедляют процессы. 


\section{СТАБИЛИЗАЦИЯ СВОЙСТВ ТОПЛИВНО-ЭНЕРГЕТИЧЕСКИХ СИСТЕМ НА ОСНОВЕ ПРИРОДНЫХ И СИНТЕТИЧЕСКИХ ПОЛИМЕРОВ}

Основным допущением термодинамики при этом является предположение о существовании в системе локального статистического равновесия частиц, которое дает возможность проводить расчеты с привлечением математического аппарата равновесной термодинамики.

Термодинамическое моделирование является разновидностью математического моделирования. Его основными этапами являются: 1- создание термодинамической модели; 2- разработка математической модели; 3- разработка алгоритма и программная реализация; 4- подготовка исходных данных; 5- проведение расчета; 6- анализ результатов вычислений.

Компонентами термодинамической модели являются: совокупность допущений о физико-химическом характере системы - степень достижения равновесия, перечень молекулярных форм, присутствующих в равновесной системе, условия равновесия (сведения об элементном составе и термодинамических параметрах, которые характеризуют равновесное состояние; информация о термодинамических свойствах веществ, которые образуют равновесную систему; физико-химические модели фаз системы уравнения состояния фаз или функциональные зависимости характеристических функций фаз от состава и термодинамических параметров системы. Далее формируется математическая модель, которая отражает термодинамические свойства химически реагирующих систем, важнейшие свойства физической модели. Иными словами, математическая модель - это математический образ физической модели. Затем на основании математических соотношений создается алгоритм расчета, который, в свою очередь реализуется в виде компьютерной программы. Для проведения вычислений необходимо задать параметры модели (термодинамические свойства веществ, параметры уравнений состояния и моделей растворов) и провести расчет [59]. 


\subsection{1 Теоретическое обоснование выбора модели горения углеводородов}

Построение термодинамической модели рассмотрим на примере исследования процесса горения углеводородов в двигателях внутреннего сгорания (ДВС). При температуре пламени выше 1500 К микрочастицы атомов и молекул в результате теплового движения движутся с большой скоростью и могут переходить с одного энергетического уровня на другой. Состав активных радикалов и соотношение между их концентрациями определяются кинетическими факторами. Элементарные равновесные реакции возникновения и исчезновения активных частиц протекают быстро и устанавливается квазистационарное равновесие, которое возможно описать с помощью законов статистической термодинамики - суммой состояния системы, учитывающая энергии всех отдельных частиц.

В связи с тем, что горение топлива протекает в камере сгорания ДВС при температурах 500..700K через стадию диспергирования (распыления) с образованием топливных эмульсий по типу жидкость - газ. В топливных эмульсиях дисперсной фазой являются капли жидкого углеводорода, которая затем переходит в газообразную дисперсную систему газ/газ с последующим окислением газообразных веществ.

Согласно законам статистической термодинамики, скорость активизации простых атомов $(\mathrm{H}, \mathrm{O}, \mathbf{N})$ и молекул $\left(\mathrm{H}_{2}, \mathrm{O}_{2}, \mathbf{N}_{2}, \mathrm{H}_{2} \mathrm{O}\right)$ во много выше скорости активизации углеводородных молекул $\mathrm{C}_{\mathrm{m}} \mathrm{H}_{\mathrm{n}}$. Поэтому общая скорость горения углеводородов определяется лимитирующей стадией деструкции углеводородов. Состав образующихся промежуточных активных частиц: атомов: азота - $\mathrm{N}^{*}$, кислорода - $\mathrm{O}^{*}$, водорода $-\mathrm{H}^{*}$, неорганических радикалов: $\mathrm{OH} \cdot, \mathrm{H} \cdot, \mathrm{CH} \cdot, \mathrm{HCN} \cdot, \mathrm{NH} \cdot$, углеводородных радикалы - R•; комплексов переменного состава: $\mathrm{HO}_{2}{ }^{*}, \mathrm{O}_{2} \mathrm{H}_{2}{ }^{*}, \mathrm{CH}_{2}{ }^{*}, \mathrm{NH}_{2}{ }^{*}$, зависит от состава и соотношения компонентов топливной эмульсии в начальный момент времени. 
Обобщенную реакцию горения газообразных углеводородов $\left(\mathrm{C}_{\mathrm{m}} \mathrm{H}_{\mathrm{n}}\right)$ протекающей с образованием диоксида углерода и воды можно представить уравнением

$$
\mathrm{C}_{\mathrm{m}} \mathrm{H}_{\mathrm{n}}+(m+0,25 n) \mathrm{O}_{2}=m \mathrm{CO}_{2}+0,5 n \mathrm{H}_{2} \mathrm{O} .
$$

Этот процесс происходит через ряд последовательных реакций:

$$
\begin{gathered}
\mathrm{C}_{\mathrm{m}} \mathrm{H}_{\mathrm{n}}=\mathrm{mC}+0,5 \mathrm{nH}_{2} \rightarrow \mathrm{C}+0,5 \mathrm{O}_{2}=\mathrm{CO} \rightarrow 2 \mathrm{H}_{2}+\mathrm{O}_{2}+\frac{79}{21} \mathrm{~N}_{2}=2 \mathrm{H}_{2} \mathrm{O}+ \\
+3,76 \mathrm{~N}_{2} \rightarrow \mathrm{CO}_{2}+\mathrm{C}=2 \mathrm{CO} .
\end{gathered}
$$

Молекула водорода $\mathrm{H}_{2}$, сталкиваясь с активным радикалом углеводорода $\mathrm{R} \cdot$, распадается на два активных атома водорода, который сталкиваясь с нейтральными молекулами кислорода, образуют новые активные радикалы $\mathrm{OH}$ и $\mathrm{H} \bullet$ по схеме:

$$
\begin{gathered}
\mathrm{H}_{2}+\mathrm{R} \cdot=2 \mathrm{H}^{*}+\mathrm{R} \rightarrow \mathrm{H}^{*}+\mathrm{O}_{2}=\mathrm{OH} \cdot+\mathrm{O}^{*} \\
\mathrm{H}^{*}+\mathrm{O}_{2}=\mathrm{OH} \cdot+\mathrm{H}^{*} \\
\mathrm{OH} \cdot+\mathrm{H}_{2}=\mathrm{H}_{2} \mathrm{O}+\mathrm{H}^{*} \quad \mathrm{OH} \cdot+\mathrm{H}^{*}=\mathrm{H}_{2} \mathrm{O} .
\end{gathered}
$$

Параллельные реакции можно записать в виде схемы

$$
\begin{gathered}
\mathrm{C}_{\mathrm{m}} \mathrm{H}_{\mathrm{n}}-\mathrm{CO}_{2}+\mathrm{H}_{2} \mathrm{O} \\
\mathrm{C}+\mathrm{H}_{2} \\
2 \mathrm{H}_{2}+\mathrm{O}_{2}+\frac{79}{21} \mathrm{~N}_{2}=2 \mathrm{H}_{2} \mathrm{O}+3,76 \mathrm{~N}_{2} .
\end{gathered}
$$

Общий итог единичного цикла записывают по схеме

$$
\begin{aligned}
\mathrm{H}^{*}+\mathrm{O}_{2}+3 \mathrm{H}_{2} & =3 \mathrm{H}^{*}+2 \mathrm{H}_{2} \mathrm{O} \\
\mathrm{O}_{2}+\mathrm{H}^{*} & =\mathrm{HO}_{2} .
\end{aligned}
$$

Горение углерода, серы, водорода можно описать реакциями

$$
\begin{gathered}
\mathrm{C}+\mathrm{O}_{2}=\mathrm{CO}_{2} \\
\mathrm{H}_{2}+0,5 \mathrm{O}_{2}=\mathrm{H}_{2} \mathrm{O} .
\end{gathered}
$$


Конечными продуктами полного сгорания углеводородов являются

$$
\mathrm{CO}_{2} \text { и } \mathrm{H}_{2} \mathrm{O} \text {. }
$$

При неполном сгорании углеводородов возможно образование сажи углерод (C) и газообразных оксидов углерода: $\mathrm{CO}$ (угарный газ).

С помощью кинетических инструментариев на примере модельных систем топливных смесей: : $\mathrm{C}_{\mathrm{m}} \mathrm{H}_{\mathrm{n}}-\mathrm{H}_{2}-$ воздух, $\mathrm{C}_{\mathrm{m}} \mathrm{H}_{\mathrm{n}}-\mathrm{H}_{2}-\mathrm{CO}-$ воздух изучен механизм горения углеводородов в ДВС и обоснована гипотеза цепного механизма образования оксидов азота: $\mathrm{NO}, \mathrm{NO}_{2}, \mathrm{~N}_{2} \mathrm{O}$, $\mathrm{NO}$ в условиях квазистационарного равновесия. Молекулярный кислород расходуется на образование активных частиц, которые при столкновении с молекулярным азотом - $\mathrm{N}_{2}$ образует оксиды азота $-\mathrm{NO}_{\mathrm{x}}$. Основной недостаток такой модели заключается в упрощении схемы образования оксидов азота до NO и низкой его селективности [60]. Состояние статистического термодинамического равновесия в реакционной зоне пламени устанавливается через ряд последовательных элементарных равновесных реакций линейных молекул (p.3.1 - p.3.4) мгновенно, примерно в начальный период времени:

$$
\begin{gathered}
\mathrm{OH}^{*}+\mathrm{H}_{2} \leftrightarrow \mathrm{H}_{2} \mathrm{O}+\mathrm{H}^{*}, \\
\mathrm{O}^{*}+\mathrm{H}_{2} \leftrightarrow \mathrm{OH}^{*}+\mathrm{H}^{*}, \\
\mathrm{H}^{*}+\mathrm{O}_{2} \leftrightarrow \mathrm{OH}^{*}+\mathrm{O}^{*}, \\
\mathrm{OH}^{*}+\mathrm{OH}^{*} \leftrightarrow \mathrm{O}^{*}+\mathrm{H}_{2} \mathrm{O} .
\end{gathered}
$$

При горении водорода с кислородом в стабильной зоне пламени уменьшение концентрации радикалов в направлении полного равновесия происходит через ряд основных относительно медленных равновесных реакций рекомбинаций:

$$
\begin{aligned}
& \mathrm{H} \bullet+\mathrm{O}_{2}+\mathrm{M} \leftrightarrow \mathrm{HO}_{2} \bullet+\mathrm{M}, \\
& \mathrm{H} \bullet+\mathrm{H} \bullet+\mathrm{M} \leftrightarrow \mathrm{H}_{2}+\mathrm{M}, \\
& \mathrm{H} \bullet+\mathrm{OH} \bullet+\mathrm{M} \leftrightarrow \mathrm{H}_{2} \mathrm{O}+\mathrm{M}, \\
& \mathrm{H} \bullet+\mathrm{O} \bullet+\mathrm{M} \leftrightarrow \mathrm{OH} \bullet+\mathrm{M}
\end{aligned}
$$


и дополнительных реакций с бимолекулярными радикалами:

$$
\begin{gathered}
\mathrm{H}+\mathrm{HO}_{2} \cdot \leftrightarrow \mathrm{OH} \cdot+\mathrm{OH}, \\
\mathrm{H}+\mathrm{HO}_{2} \cdot \leftrightarrow \mathrm{O}+\mathrm{H}_{2} \mathrm{O}, \\
\mathrm{H}+\mathrm{HO}_{2} \cdot \leftrightarrow \mathrm{H}_{2}+\mathrm{O}_{2}, \\
\mathrm{OH} \cdot+\mathrm{HO}_{2} \cdot \leftrightarrow \mathrm{H}_{2} \mathrm{O}+\mathrm{O}_{2}, \\
\mathrm{O}+\mathrm{HO}_{2} \cdot \leftrightarrow \mathrm{OH} \cdot+\mathrm{O}_{2} .
\end{gathered}
$$

Образование в продуктах сгорания углеводородного горючего других оксида и диоксида углерода возможно при протекании обратимых реакций:

$$
\begin{gathered}
\mathrm{OH} \cdot+\mathrm{CO} \leftrightarrow \mathrm{CO}_{2}+\mathrm{H}, \\
\mathrm{O}+\mathrm{CO}+\mathrm{M} \leftrightarrow \mathrm{CO}_{2}+\mathrm{M}, \\
\mathrm{H}+\mathrm{CO}+\mathrm{M} \leftrightarrow \mathrm{HCO}+\mathrm{M} .
\end{gathered}
$$

В то же время, при исследовании пламени смеси водород - оксид углерода - воздух было обнаружено, что при смещении от стехиометрического состава в сторону обогащения топливной смеси горючим углеводородом реакции р.3.1 и р.3.5 невозможны при температуре пламени ниже 1500 К.

Горение углеводородов при высоких температурах может протекать при малых и больших концентрациях радикалов. Первая ситуация характерна для процессов воспламенения в ударных условиях; вторая ситуация отвечает условиям стационарного пламени. В топливных смесях с низким содержанием метана $-\mathrm{CH}_{4}$ и кислорода $-\mathrm{O}_{2}$ с участие метана в реакции инициирования скорости реакций зарождения цепи незначительно и может не учитываться при моделировании продуктов сгорания. Наиболее эффективными методами расчета химического равновесия являются методы, разработанные Я.Б. Зельдовичем, В.П. Глушко, Н.С. Семеновым, которые в дальнейшем были расширены многочисленными исследованиями, и применяются при изучении образования оксидов азота [61]. 


\section{СТАБИЛИЗАЦИЯ СВОЙСТВ ТОПЛИВНО-ЭНЕРГЕТИЧЕСКИХ СИСТЕМ НА ОСНОВЕ ПРИРОДНЫХ И СИНТЕТИЧЕСКИХ ПОЛИМЕРОВ}

Модель реакций образования оксидов азота основана на гипотезе неразветвленной цепной реакции, в которой инициирование возможно при окисления атомарного азота:

$$
\begin{aligned}
& \mathrm{N}_{2}+\mathrm{O}=\mathrm{NO}+\mathrm{N}, \\
& \mathrm{N}+\mathrm{O}_{2}=\mathrm{NO}+\mathrm{O} .
\end{aligned}
$$

Согласно этой гипотезе механизм окисления азота воздуха при горении топлива в диапазоне температур 500..700К и выше состоит в образовании равновесной многокомпонентной смеси газообразных веществ: $\mathrm{N}_{2}, \mathrm{~N}_{2} \mathrm{O}, \mathrm{NO}_{2}$, $\mathrm{NO}, \mathrm{NH}, \mathrm{N}, \mathrm{C}_{\mathrm{n}} \mathrm{H}_{\mathrm{m}}$ и других соединений и определяется следующими основными положениями: 1. окисление азота происходит за фронтом пламени в зоне продуктов сгорания; 2. выход оксидов азота определяется максимальной температурой сгорания, концентрацией азота и кислорода в продуктах сгорания и не зависит от химической природы топлива, участвующего в реакции (при отсутствии в топливе азота); 3. окисление азота происходит по цепному механизму взаимодействия атомов и молекул азота и кислорода; 4. выход оксидов азота зависит от скорости охлаждения продуктов сгорания.

Неравномерное распределение температуры в зоне продуктов сгорания значительно влияет на образование оксидов азота. По термодинамической устойчивости образующиеся оксиды азота располагаются в ряд по убыванию [25]

$$
\mathrm{NO}, \mathrm{N}_{2} \mathrm{O}, \mathrm{NO}_{2}, \mathrm{~N}_{2} \mathrm{O}_{3}, \mathrm{~N}_{2} \mathrm{O}_{4}, \mathrm{~N}_{2} \mathrm{O}_{5}, \mathrm{~N} \text {, }
$$

то есть в равновесной газовой смеси преобладает оксид азота NO. Фактически, для изучения процесса образования оксидов азота необходимо применять математическое моделирование, используя схему из более, чем 200 химический реакций, приводящих к образованию основных оксидов азота геми (закись), ди- и окси-: $\mathrm{N}_{2} \mathrm{O}, \mathrm{NO}_{2}, \mathrm{NO}$.

Применение термодинамических инструментариев позволяет считать процесс горения жидкого топлива и образования оксидов азота равновесным процессом и представить как сумму элементарных реакций, для которых 105 


\section{СТАБИЛИЗАЦИЯ СВОЙСТВ ТОПЛИВНО-ЭНЕРГЕТИЧЕСКИХ СИСТЕМ НА ОСНОВЕ ПРИРОДНЫХ И СИНТЕТИЧЕСКИХ ПОЛИМЕРОВ}

условия протекания определяются численным моделированием процесса горения простейших углеводородов. Химические реакции взаимодействия веществ записываются в виде системы дифференциальных уравнений, учитывающих приход-расход вещества в этих реакциях. Система уравнений решается для всех прямых и обратных процессов по существующим данных о константах реакций.

Используя результаты моделирования изотермических систем, в частности горение смеси водорода и кислорода, метана и кислорода, пропана и кислорода, кроме того, суммируя известные данные протекания элементарных реакций и выделяя из них наиболее весомые представлены в таблице 3.2, исключая процессы с большим энергиями активации.

Основной вклад в образование $\mathrm{N}_{2} \mathrm{O}$ дают две реакции:

$$
\begin{aligned}
& \mathrm{N}_{2}+\mathrm{HO}_{2} \cdot \rightarrow \mathrm{N}_{2} \mathrm{O}+\mathrm{OH} . \\
& \mathrm{N}_{2}+\mathrm{O}+\mathrm{M} \rightarrow \mathrm{N}_{2} \mathrm{O}+\mathrm{M},
\end{aligned}
$$

при этом вклад реакции р.м.1.1 примерно в 5 раз больше влияния реакции p.M.1.2.

Таблица 3.2

Элементарные реакции образования оксидов азота

\begin{tabular}{|c|c|c|c|c|}
\hline $\begin{array}{c}\text { № } \\
\text { реакции } \\
\text { по } \\
\text { модели }\end{array}$ & $\begin{array}{c}\text { Реакция по модели } \\
\text { (р.м.) }\end{array}$ & $\begin{array}{c}\text { Относительное } \\
\text { количество } \\
\text { вещества }\end{array}$ & $\begin{array}{c}\text { Константы } \\
\text { реакции }\end{array}$ \\
\hline 1 & 2 & 3 & 4 & 5 \\
\hline 1. & 1.1. & $\mathrm{~N}_{2}+\mathrm{HO}_{2} \cdot \rightarrow \mathrm{N}_{2} \mathrm{O}+\mathrm{OH}$ & $5: 1=1.1: 1.2$ & \\
\hline & 1.2. & $\mathrm{~N}_{2}+\mathrm{O}+\mathrm{M} \rightarrow \mathrm{N}_{2} \mathrm{O}+\mathrm{M}$ & & $10^{13,88} \mathrm{e}^{-7600 / \mathrm{T}}$ \\
\hline 2. & 2.1. & $\mathrm{~N}_{2} \mathrm{O}+\mathrm{H} \rightarrow \mathrm{N}_{2}+\mathrm{OH} \cdot$ & & $2,39 \cdot 10^{17} \mathrm{e}^{-7549 / \mathrm{T}}$ \\
\hline & 2.2. & $\mathrm{~N}_{2} \mathrm{O}+\mathrm{OH} \rightarrow \mathrm{N}_{2}+\mathrm{HO}_{2} \cdot$ & $0,78: 0,22: 0,02=$ & $10^{13,84} \mathrm{e}^{-13400 / \mathrm{T}}$ \\
\hline & 2.3. & $\mathrm{~N}_{2} \mathrm{O}+\mathrm{O} \rightarrow \mathrm{N}_{2}+\mathrm{O}_{2}$ & $=2.1: 2.2: 2.3$ & $1,6 \cdot 10^{14} \mathrm{e}^{-51600 / \mathrm{T}}$ \\
\hline & 2.4. & $\mathrm{~N}_{2} \mathrm{O} \rightarrow \mathrm{N}_{2}+\mathrm{O}$ & &
\end{tabular}


Продолжение таблицы 3.2

\begin{tabular}{|c|c|c|c|c|}
\hline 3. & 3.1 . & $\mathrm{NO}_{2}+\mathrm{H} \rightarrow \mathrm{NO}+\mathrm{OH}$ & $97 \% \Sigma \mathrm{NO}_{2}$ & $10^{13,88} \mathrm{e}^{-7600 / \mathrm{T}}$ \\
\hline & 3.2. & $\mathrm{NO}_{2}+\mathrm{M} \rightarrow \mathrm{NO}+\mathrm{O}+\mathrm{M}$ & & $10^{16,04} \mathrm{e}^{-33000 / \mathrm{T}}$ \\
\hline & 3.3. & $\mathrm{NO}_{2}+\mathrm{O} \rightarrow \mathrm{NO}+\mathrm{O}_{2}$ & & $10^{13,0} \mathrm{e}^{-300 / \mathrm{T}}$ \\
\hline & 3.4 . & $\mathrm{NO}_{2}+\mathrm{N} \rightarrow \mathrm{NO}+\mathrm{NO}$ & & $10^{12,6}$ \\
\hline \multirow[t]{4}{*}{4.} & 4.1. & $\mathrm{NO}+\mathrm{HO}_{2} \cdot \rightarrow \mathrm{NO}_{2}+\mathrm{OH}$ & $38 \%$ от $\Sigma \mathrm{NO}_{2}$ & \\
\hline & 4.2. & $\mathrm{NO}+\mathrm{O}+\mathrm{M} \rightarrow \mathrm{NO}_{2} \cdot \mathrm{M}$ & & \\
\hline & 4.3. & $\mathrm{NO}+\mathrm{OH} \cdot \rightarrow \mathrm{NO}_{2}+\mathrm{H}$ & $52 \%$ от $\Sigma \mathrm{NO}_{2}$ & \\
\hline & 4.4. & $\mathrm{NO}+\mathrm{N}_{2} \mathrm{O} \rightarrow \mathrm{NO}_{2}+\mathrm{N}_{2}$ & & $10^{14} \mathrm{e}^{-49700 / \mathrm{T}}$ \\
\hline 5. & & $\mathrm{HNO}+\mathrm{O} \rightarrow \mathrm{NO}_{2}+\mathrm{H}$ & весь HNO в NO & \\
\hline 1 & 2 & 3 & 4 & 5 \\
\hline \multirow[t]{2}{*}{7.} & 7.1. & $\mathrm{~N}+\mathrm{OH} \cdot+\mathrm{M} \rightarrow \mathrm{HNO}+\mathrm{M}$ & & \\
\hline & 7.2. & $\mathrm{~N}+\mathrm{HO}_{2} \cdot \rightarrow \mathrm{HNO}+\mathrm{O}$ & весь $\mathrm{HNO}$ в NO & \\
\hline 9. & & $\mathrm{~N}_{2}+\mathrm{M} \rightarrow \mathrm{N}+\mathrm{N}+\mathrm{M}$ & & \\
\hline \multirow[t]{2}{*}{11.} & 11.1. & $\mathrm{~N}+\mathrm{OH} \cdot \rightarrow \mathrm{NO}+\mathrm{H}$ & $77,4 \%$ от $\mathrm{NO}$ & $1,0 \cdot 10^{14}$ \\
\hline & 11.2 . & $\mathrm{N}+\mathrm{O}_{2} \rightarrow \mathrm{NO}+\mathrm{O}$ & $0,6: 0,3=11.1: 11.2$ & $6,4 \cdot 10^{9} \mathrm{e}^{-3150 / \mathrm{T}}$ \\
\hline 12. & & $\mathrm{NO}+\mathrm{H} \rightarrow \mathrm{N}+\mathrm{OH}$. & & $10^{14,23} \mathrm{e}^{-24569 / \mathrm{T}}$ \\
\hline 13. & & $\mathrm{~N}+\mathrm{O}_{2} \rightarrow \mathrm{N}_{2} \mathrm{O}+\mathrm{O}$ & & $5,01 \cdot 10^{12}$ \\
\hline \multirow[t]{6}{*}{15.} & 15.1. & $\mathrm{HNO}+\mathrm{OH} \cdot \rightarrow \mathrm{NO}+\mathrm{H}_{2} \mathrm{O}$ & $8,6 \%$ от $\Sigma \mathrm{NO}$ & $10^{12,1} \cdot \mathrm{T}^{0,5} \mathrm{e}^{-1000 / \mathrm{T}}$ \\
\hline & 15.2 . & $\mathrm{HNO}+\mathrm{O} \rightarrow \mathrm{NO}+\mathrm{OH}$ & $14 \%$ от $\Sigma \mathrm{NO}$ & $10^{11,7} \cdot \mathrm{T}^{0,5} \mathrm{e}^{-1000 / \mathrm{T}}$ \\
\hline & 15.3. & $\mathrm{HNO}+\mathrm{M} \rightarrow \mathrm{NO}+\mathrm{H}+\mathrm{M}$ & & $10^{16,3} \mathrm{e}^{-24500 / \mathrm{T}}$ \\
\hline & 15.4 . & $\mathrm{HNO}+\mathrm{H} \rightarrow \mathrm{NO}+\mathrm{H}_{2}$ & весь в NO & $10^{13,1} \mathrm{e}^{-2000 / \mathrm{T}}$ \\
\hline & 15.5 . & $\mathrm{HNO}+\mathrm{HO}_{2} \cdot \rightarrow \mathrm{NO}+\mathrm{H}_{2} \mathrm{O}_{2}$ & & $10^{11,5} \cdot \mathrm{T}^{0,5} \mathrm{e}^{-1000 / \mathrm{T}}$ \\
\hline & 15.6. & $\mathrm{HNO}+\mathrm{N} \rightarrow \mathrm{NO}+\mathrm{NH} \cdot$ & & $10^{13,0} \mathrm{e}^{-1000 / \mathrm{T}}$ \\
\hline 16. & & $\mathrm{NO}+\mathrm{H}+\mathrm{M} \rightarrow \mathrm{HNO}+\mathrm{M}$ & $19 \%$ от $\Sigma \mathrm{NO}$ & \\
\hline 18. & & $\mathrm{NO}+\mathrm{HO}_{2} \cdot \rightarrow \mathrm{NH} \cdot+\mathrm{O}_{2}$ & & \\
\hline 19. & & $\mathrm{NH} \cdot+\mathrm{O} \rightarrow \mathrm{NO}+\mathrm{H}$ & & \\
\hline \multirow[t]{3}{*}{21.} & 21.1. & $\mathrm{~N}_{2} \mathrm{O}+\mathrm{O} \rightarrow \mathrm{NO}+\mathrm{NO}$ & & $10^{13,84} \mathrm{e}^{-13400 / \mathrm{T}}$ \\
\hline & 21.2 . & $\mathrm{N}_{2} \mathrm{O}+\mathrm{H} \rightarrow \mathrm{NO}+\mathrm{NH}$ & весь в $\mathrm{NO}_{2}$ в $\mathrm{NO}$ & $10^{14,28} \mathrm{e}^{-17360 / \mathrm{T}}$ \\
\hline & 21.3. & $\mathrm{~N}_{2} \mathrm{O}+\mathrm{N} \rightarrow \mathrm{NO}+\mathrm{N}_{2}$ & $90 \% \mathrm{NO}$ & $5,01 \cdot 10^{8} \mathrm{e}^{-5033 / \mathrm{T}}$ \\
\hline 22. & & $\mathrm{NO}+\mathrm{NH} \cdot \rightarrow \mathrm{N}_{2} \mathrm{O}+\mathrm{H}$ & & \\
\hline \multirow[t]{3}{*}{23.} & 23.1. & $\mathrm{NH} \cdot+\mathrm{OH} \cdot \rightarrow \mathrm{HNO}+\mathrm{H}$ & & \\
\hline & 23.2. & $\mathrm{NH}+\mathrm{NO}_{2} \rightarrow \mathrm{HNO}+\mathrm{NO}$ & & \\
\hline & 23.3 . & $\mathrm{NH} \cdot+\mathrm{HO}_{2} \cdot \rightarrow \mathrm{HNO}+\mathrm{OH}$ & & \\
\hline
\end{tabular}


Продолжение таблицы 3.2

\begin{tabular}{|c|c|c|c|c|}
\hline & 23.4 . & $\mathrm{NH} \cdot+\mathrm{N}_{2} \mathrm{O} \rightarrow \mathrm{HNO}+\mathrm{N}_{2}$ & & \\
\hline & 23.5 . & $\mathrm{NH} \cdot+\mathrm{O}_{2} \rightarrow \mathrm{HNO}+\mathrm{O}$ & & \\
\hline 25. & & $\mathrm{~N}_{2}+\mathrm{O} \rightarrow \mathrm{NO}+\mathrm{N}$ & $0,7 \%$ от $\Sigma \mathrm{NO}$ & $7,6 \cdot 10^{13} \mathrm{e}^{-38000 / \mathrm{T}}$ \\
\hline 1 & 2 & 3 & 4 & 5 \\
\hline 27. & 27. & $\mathrm{~N}_{2}+2 \mathrm{C} \rightarrow 2 \mathrm{CN}$ & & $10^{13} \mathrm{e}^{-2516 / \mathrm{T}}$ \\
\hline \multirow[t]{2}{*}{29.} & 29.1. & $\mathrm{~N}_{2}+\mathrm{CH} \cdot \rightarrow \mathrm{HCN} \cdot+\mathrm{N}$ & & \\
\hline & 29.2 . & $\mathrm{N}_{2}+\mathrm{CH}_{2} \cdot \rightarrow \mathrm{HCN} \cdot+\mathrm{NH} \cdot$ & $0,9 \%$ от $\Sigma \mathrm{HCN}$. & $1,0 \cdot 10^{13} \mathrm{e}^{-74000 / \mathrm{RT}}$ \\
\hline \multirow[t]{3}{*}{30.} & 30.1 . & $\mathrm{HCN} \cdot+\mathrm{H} \rightarrow \mathrm{CN} \cdot+\mathrm{H}_{2}$ & $10 \%$ от $\Sigma \mathrm{HCN}$. & \\
\hline & 30.2 . & $\mathrm{HCN} \cdot+\mathrm{OH} \cdot \rightarrow \mathrm{CN} \cdot+\mathrm{H}_{2} \mathrm{O}$ & $0,5 \Sigma \mathrm{HCN}$. & $1,45 \cdot 10^{3} \mathrm{e}^{-10929 / \mathrm{T}}$ \\
\hline & 30.3 . & $\mathrm{HCN}++\mathrm{O} \rightarrow \mathrm{CN} \cdot+\mathrm{OH}$ & & $2,7 \cdot 10^{9} \mathrm{e}^{-26800 / \mathrm{T}}$ \\
\hline \multirow[t]{4}{*}{31.} & 31.1 . & $\mathrm{CN} \cdot+\mathrm{H}_{2} \rightarrow \mathrm{HCN} \cdot+\mathrm{H}$ & & $2,95 \cdot 10^{5} \mathrm{e}^{-2237 / \mathrm{T}}$ \\
\hline & 31.2 . & $\mathrm{CN} \cdot+\mathrm{CH}_{4} \rightarrow \mathrm{HCN} \cdot+\mathrm{CH}_{3} \cdot$ & & $9,03 \cdot 10^{12} \mathrm{e}^{-1868 / \mathrm{T}}$ \\
\hline & 31.3 . & $\mathrm{CN} \cdot+\mathrm{OH} \cdot \rightarrow \mathrm{HCN} \cdot+\mathrm{O}$ & $0,1 \% \mathrm{CN}$. & \\
\hline & 31.4 . & $\mathrm{CN} \cdot+\mathrm{H}_{2} \mathrm{O} \rightarrow \mathrm{HCN} \cdot+\mathrm{OH} \cdot$ & $\mathrm{CN} \approx \mathrm{HCN}$. & \\
\hline 33. & & $\mathrm{HCN} \cdot+\mathrm{O} \rightarrow \mathrm{NH} \cdot+\mathrm{CO}$ & & $3,45 \cdot 10^{9} \mathrm{e}^{-4980 / \mathrm{T}}$ \\
\hline 34. & & $\mathrm{NH} \cdot+\mathrm{CH} \cdot \rightarrow \mathrm{HCN} \cdot+\mathrm{H}$ & весь $\mathrm{NH} \cdot$ в $\mathrm{HCN}$. & $10^{13} \mathrm{e}^{-2514 / \mathrm{T}}$ \\
\hline 35. & & $\mathrm{~N}+\mathrm{CH} \cdot \rightarrow \mathrm{CN} \cdot+\mathrm{H}$ & & $8 \cdot 10^{11} \mathrm{e}^{-5560 / \mathrm{T}}$ \\
\hline 36. & & $\mathrm{CN} \cdot+\mathrm{O} \rightarrow \mathrm{N}+\mathrm{CO}$ & весь CN. & $5,00 \cdot 10^{12}$ \\
\hline 37. & & $\mathrm{~N}+\mathrm{CH}_{2} \cdot \rightarrow \mathrm{HCN} \cdot+\mathrm{H}$ & & $5,0 \cdot 10^{13}$ \\
\hline 38. & & $\mathrm{HCN} \cdot+\mathrm{O} \rightarrow \mathrm{N}+\mathrm{CHO}$ & & \\
\hline
\end{tabular}

Механизм образования оксидов азота в процессе горения топлива в дизелях можно представлен граф-моделью (рис. 3.3). Весь процесс делится на две части: образование термических и быстрых NO. Дуги графа 1 . . 27 соответствуют основным реакциям, протекание которых определяет выход оксидов азота. В процессе горения характеризуется высокой скоростью образования и исчезновения активных частиц. Номерами обозначены комплексы реакций, приводящие к образованию соответствующего вещества. Обратные реакции обозначаются соответствующими четными номерами. Расход $\mathrm{N}_{2} \mathrm{O}$ осуществляется по реакциям:

$$
\mathrm{N}_{2} \mathrm{O}+\mathrm{H} \rightarrow \mathrm{N}_{2}+\mathrm{OH} \cdot
$$




$$
\begin{gathered}
\mathrm{N}_{2} \mathrm{O}+\mathrm{OH} \cdot \rightarrow \mathrm{N}_{2}+\mathrm{HO}_{2} \cdot \\
\mathrm{N}_{2} \mathrm{O}+\mathrm{O} \rightarrow \mathrm{N}_{2}+\mathrm{O}_{2},
\end{gathered}
$$

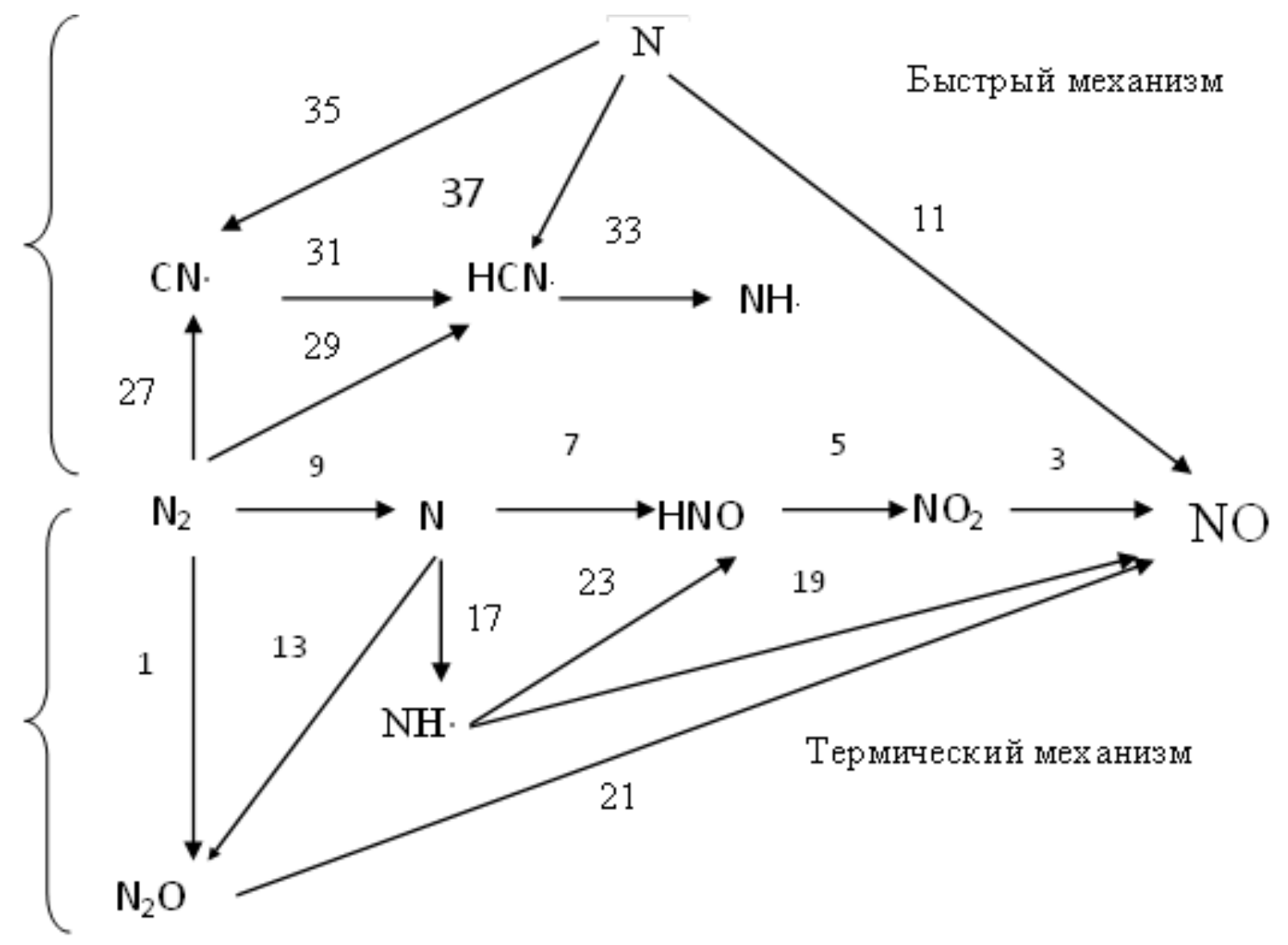

Рис. 3.3. Граф-модель образования оксидов азота в камере сгорания ДВС

Суммарный расход $\mathrm{N}_{2} \mathrm{O}$ составляет $93 \%$ от его суммарного прихода, т.е. только $7 \%$ от общего количества появившегося $\mathrm{N}_{2} \mathrm{O}$ сохраняется. Почти все образование диоксида идет за счет расхода оксида азота по реакциям р.м.4.1 и p.м.4.3 (90\%), в том числе приход по реакциям 4.3 и 5 составляет $52 \%$ :

$$
\begin{gathered}
\mathrm{NO}+\mathrm{HO}_{2} \cdot \rightarrow \mathrm{NO}_{2}+\mathrm{OH} \cdot \\
\mathrm{NO}+\mathrm{O}+\mathrm{M} \rightarrow \mathrm{NO}_{2}+\mathrm{M} \\
\mathrm{NO}+\mathrm{OH} \cdot \rightarrow \mathrm{NO}_{2}+\mathrm{H} . \\
\mathrm{HNO}+\mathrm{O} \rightarrow \mathrm{NO}_{2}+\mathrm{H} .
\end{gathered}
$$

Практически расход $\mathrm{NO}_{2}$ обеспечивается одной реакцией (97 \%):

$$
\mathrm{O}_{2}+\mathrm{H} \rightarrow \mathrm{NO}+\mathrm{OH} \cdot
$$


и суммарный уход равен приходу, причем $\mathrm{NO}_{2}$ может превращаться только в NO.

Реакции образования оксида азота р.м.11 - 15.1 поставляют 86 \% от всего прихода NO:

$$
\begin{gathered}
\mathrm{N}+\mathrm{OH} \cdot \rightarrow \mathrm{NO}+\mathrm{H} \\
\mathrm{N}+\mathrm{O}_{2} \rightarrow \mathrm{NO}+\mathrm{O} \\
\mathrm{HNO}+\mathrm{OH} \cdot \rightarrow \mathrm{NO}+\mathrm{H}_{2} \mathrm{O}
\end{gathered}
$$

остальные 14 \% образуются по реакциям:

$$
\begin{gathered}
\mathrm{H}+\mathrm{NO}_{2} \rightarrow \mathrm{NO}+\mathrm{OH} \cdot \\
\mathrm{N}_{2}+\mathrm{O} \rightarrow \mathrm{NO}+\mathrm{N} \\
\mathrm{HNO}+\mathrm{O} \rightarrow \mathrm{NO}+\mathrm{OH} \cdot \\
\mathrm{HNO}+\mathrm{M} \rightarrow \mathrm{NO}+\mathrm{H}+\mathrm{M} \\
\mathrm{HNO}+\mathrm{H} \rightarrow \mathrm{NO}+\mathrm{H}_{2} \\
\mathrm{HNO}+\mathrm{HO}_{2} \cdot \mathrm{NO}+\mathrm{H}_{2} \mathrm{O}_{2} \\
\mathrm{HNO}+\mathrm{N} \rightarrow \mathrm{NO}+\mathrm{NH}^{-} \\
\mathrm{NH}+\mathrm{O} \rightarrow \mathrm{NO}+\mathrm{H},
\end{gathered}
$$

при этом реакция 13 (табл.3.2) поставляет менее 0,7 \% от всего прихода NO. Расход NO по реакции 16 составляет $19 \%$ от общего прихода NO и по реакции р.м.4.1 - 2,5 \%, а $\mathrm{NO}_{2}$ и $\mathrm{HNO}$ преобразуются обратно в NO:

$$
\begin{gathered}
\mathrm{NO}+\mathrm{H}+\mathrm{M} \rightarrow \mathrm{HNO}+\mathrm{M} \\
\mathrm{NO}+\mathrm{HO}_{2} \cdot \rightarrow \mathrm{OH} \cdot+\mathrm{NO}_{2}
\end{gathered}
$$

Образование быстрых оксидов азота осуществляется по цепному механизму:

$$
\begin{gathered}
\mathrm{N}_{2}+2 \mathrm{C} \rightarrow 2 \mathrm{CN} \cdot \\
\mathrm{N}_{2}+\mathrm{CH} \cdot \rightarrow \mathrm{HCN} \cdot+\mathrm{N} \\
\mathrm{N}+\mathrm{CH} \cdot \rightarrow \mathrm{CN} \cdot+\mathrm{H} \\
\mathrm{CN} \cdot+\mathrm{OH} \cdot \rightarrow \mathrm{HCN} \cdot+\mathrm{O} .
\end{gathered}
$$


Обратная реакция р.м.30.1 превышает приход по реакциям р.м.29.1, p.м.31.3, т.е. половина $\mathrm{HCN}$, образовавшегося по реакциям р.м.29.1,31.3, превращается в $\mathrm{CN}$ :

$$
\mathrm{HCN} \cdot+\mathrm{O} \rightarrow \mathrm{CN} \cdot+\mathrm{OH} \cdot
$$

Еще около 10\%, образовавшегося в этих реакциях $\mathrm{HCN}$, переходит в $\mathrm{CN}$. по реакции:

$$
\mathrm{HCN} \cdot+\mathrm{H} \rightarrow \mathrm{CN} \cdot+\mathrm{H}_{2}
$$

а остальные 40 \% преобразуются в $\mathrm{N}$ по реакции:

$$
\mathrm{HCN} \cdot+\mathrm{O} \rightarrow \mathrm{CHO}+\mathrm{N}
$$

Весь образовавшийся $\mathrm{CN}$. переходит в $\mathrm{N}$ по реакции:

$$
\mathrm{CN} \cdot+\mathrm{O} \rightarrow \mathrm{CO}+\mathrm{N}
$$

Возникающие в процессе цепных реакций радикалы $\mathrm{CN}$, $\mathrm{HCN} \cdot \mathrm{NH} \cdot \mathrm{N}$ являются дополнительными центрами образования оксидов азота.

\subsection{2 Термодинамическая модель образования оксидов азота}

Используя системный подход, строится термодинамическая модель, в которой многообразие веществ и радикалов, участвующих в реакциях сгорания

$\left[\mathrm{N}, \mathrm{O}, \mathrm{OH}, \mathrm{H}, \mathrm{H}, \mathrm{HO}_{2}, \mathrm{O}_{2} \mathrm{H}_{2}, \mathrm{CH}, \mathrm{CH}_{2}, \mathrm{HCN}, \mathrm{NH}, \mathrm{NH}_{2}, \mathrm{NO}, \mathrm{NO}_{2}, \mathrm{~N}_{2} \mathrm{O}\right.$,

$$
\left.\mathrm{NO}, \mathrm{CO}, \mathrm{CO}_{2}, \mathrm{C} \ldots\right] \text {, }
$$

представляется топологическим пространством Т, которое включает области равновесного состояния $\mathrm{T}_{\mathrm{p}}$, и активных зон $\mathrm{T}_{3}$, состоящие из систем с общими свойствами

$$
\mathrm{T} \subset \mathrm{T}_{\mathrm{p}} \subset\left(\mathrm{T}_{\text {и }}+\mathrm{T}_{\mathrm{\kappa}}\right)+\mathrm{T}_{3} \subset(\mathrm{M}-+\mathrm{R}-),
$$

где $T$ пространство, которое состоит из двух областей - область равновесного состояния $T_{p}$, и область активных зон $T_{3}$ (табл. 3.3 ). 


\section{СТАБИЛИЗАЦИЯ СВОЙСТВ ТОПЛИВНО-ЭНЕРГЕТИЧЕСКИХ СИСТЕМ НА ОСНОВЕ ПРИРОДНЫХ И СИНТЕТИЧЕСКИХ ПОЛИМЕРОВ}

Область равновесного состояния $\mathrm{T}$ р включает системы исходных

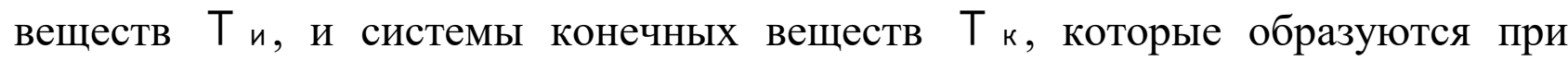
условии прохождения реакций до равновесного состояния.

Область активных зон $T_{3}$ включает системы активных комплексов $M i$ - зона активных комплексов, и системы активных центров $R i-$ зона активных центров, которые вступают во взаимодействие между собой, при этом реакции, протекающие внутри систем (между комплексами/радикалами) можно рассматривать, как реакции, протекающие в пространстве, ограниченном поверхностью раздела, то есть системы можно считать фазами.

Таблица 3.3

\section{Топология термодинамической модели}

\begin{tabular}{|c|c|c|c|}
\hline \multicolumn{4}{|c|}{ Пространство термодинамической модели $T$} \\
\hline \multicolumn{2}{|c|}{ Область равновесного состояния $\boldsymbol{T}_{\boldsymbol{p}}$} & \multicolumn{2}{|r|}{ Область активных зон $T_{3}$} \\
\hline \multirow[t]{4}{*}{$T_{u}$} & Система исходных веществ & \multirow{4}{*}{$M$} & Система активных комплексов \\
\hline & \multirow[t]{3}{*}{$\mathrm{N}_{2}, \mathrm{H}_{2}, \mathrm{O}_{2}, \mathrm{C}_{\mathrm{m}} \mathrm{H}_{\mathrm{n}}$} & & $\begin{array}{c}\mathrm{ONCH}, \mathrm{ONCO}+\mathrm{H}, \mathrm{ONC}+\mathrm{H} \\
\mathrm{CHN}+\mathrm{O}\end{array}$ \\
\hline & & & $\begin{array}{lll}\mathrm{ON}+\mathrm{HC} & \mathrm{ONH}+\mathrm{C} & \mathrm{OHC}+\mathrm{N} \\
& \mathrm{CN}+\mathrm{OH} & \end{array}$ \\
\hline & & & $\mathrm{CNH}, \quad \mathrm{CN}+\mathrm{H}, \quad \mathrm{CH}+\mathrm{N}$ \\
\hline \multirow[t]{3}{*}{$T_{\kappa}$} & $\begin{array}{l}\text { Система конечных веществ, } \\
\text { которые образуются при } \\
\text { условии прохождения } \\
\text { реакций до конца }\end{array}$ & \multirow[t]{3}{*}{$R$} & $\begin{array}{c}\text { Система } \\
\text { активных центров }\end{array}$ \\
\hline & $\mathrm{CO}_{2}, \mathrm{CO}, \mathrm{H}_{2} \mathrm{O}$ & & $\mathrm{CH}_{2}, \mathrm{CH}, \quad \mathrm{CH}_{3}$ \\
\hline & $\mathrm{NO}, \quad \mathrm{NO}_{2}, \quad \mathrm{~N}_{2} \mathrm{O}_{3}$ & & $\mathrm{HO}, \mathrm{HO}_{2}, \mathrm{H}_{2} \mathrm{O}_{2}$ \\
\hline
\end{tabular}

Системы - фазы взаимодействуют между собой, а также каждая фаза взаимодействует с областью равновесного состояния $T_{p}$, стремясь к состоянию равновесия, которое определяется из условия фазового равновесия. Для каждой системы $M_{i}, R_{i}$ и области $T_{3}$ определяются условия равновесия фаз по составу и значению химического потенциала в интервале значений давления и температур. 


\section{СТАБИЛИЗАЦИЯ СВОЙСТВ ТОПЛИВНО-ЭНЕРГЕТИЧЕСКИХ СИСТЕМ НА ОСНОВЕ ПРИРОДНЫХ И СИНТЕТИЧЕСКИХ ПОЛИМЕРОВ}

В разработанной методологии анализа деструкции топлива предлагается исследуемые процессы рассматривать как многофазные процессы многокомпонентной систем. В методологии исследований сложных систем при построении структурной модели используются следующие общие положения.

1. Основные положения классической и химической термодинамики, в том числе уравнение Гиббса, которое выполняется для каждой фазы гетерогенной системы, находящейся в равновесии.

2. При построении структурной модели, следуя принципу - от простого к сложному, за основу функциональной модели выбирается дифференциальное уравнение для бинарных систем ( $\mathrm{n}=2, \mathrm{r}=2)$ Ван-дер-Ваальса, которое определяет условие равновесия для бинарных двухфазных систем и является справедливым для любых двух сосуществующих фаз. Это уравнение совместно с условиями стабильности дает исчерпывающую характеристику термодинамических свойств двухкомпонентных двухфазных систем. Решение данной системы в общей форме дают известные законы Гиббса-Коновалова.

3. Методы Ван-дер-Ваальса и Гиббса, характеризующиеся использованием молярных дробей для выражения составов систем в барицентрических координатах при графическом изображении системы. Так как при этом способе выражение состава концентрации удовлетворяет условию

$$
\sum_{j} a_{i j} \cdot Y_{j}=b_{j},
$$

то число переменных сокращается на единицу, т.е. число независимых переменных состояний и число уравнений, необходимых для описания состояния системы, также уменьшается на единицу.

4. Термодинамические закономерности рассматриваются поэтапно, в следующей последовательности: равновесное $\rightarrow$ стабильное $\rightarrow$ экстремальное состояния.

5. Структурная модель имеет три уровня. 


\section{СТАБИЛИЗАЦИЯ СВОЙСТВ ТОПЛИВНО-ЭНЕРГЕТИЧЕСКИХ СИСТЕМ НА ОСНОВЕ ПРИРОДНЫХ И СИНТЕТИЧЕСКИХ ПОЛИМЕРОВ}

На первом уровне исследований процесс представляется системой, состоящей из многокомпонентной однофазной и однокомпонентной однофазной подсистемами, то есть система состоит из $\mathrm{n}$ компонентов в фазе $\mathrm{r}$ и одного компонента в фазе $r$; при допущении, что гравитационные и капиллярные силы оказывают незначительное влияние. На втором уровне ( $\mathrm{n}+$ 2) рассматривается многокомпонентная двухфазная система. На третьем уровне $(n+r)$ исследуется многокомпонентная $(n)$ многофазная $(r)$ система. На каждом уровне решаются две задачи: - составляются дифференциальные уравнения для сосуществующих фаз систем, которые являются условием равновесия системы, и определяются ограничения, необходимые для их решения; - определяется условие стабильности и экстремума сосуществующих фаз. Полученные закономерности, проявляющиеся в условиях экстремума значений характеристических функций, позволяют дать полную термодинамическую характеристику процессов сгорания топлива, в том числе качественное и количественное изменение состава топливо-воздушной смеси в зависимости от условий сгорания, - главным образом наблюдаемых температур и давлений

Процесс деструкции топливо-воздушной смеси рассматривается как взаимодействие веществ, заданных материальным балансом (уравнение 3.22). Значения постоянной $b_{i}$ в левой части уравнений (3.22) устанавливаются оценкой исходного состава газовой смеси. Для этого определяется соотношение топлива и воздуха рабочего процесса двигателя для определенного режима работы двигателя, условия смесеобразования, значений регулировочных параметров топливной аппаратуры.

Для исследования разработанной модели и ее элементов использовалась разработанная программа расчета «Расчет продуктов сгорания» [31], с помощью которой определяются экстремальные состояния систем или концентрация веществ в узловых точках материального баланса для 


\section{СТАБИЛИЗАЦИЯ СВОЙСТВ ТОПЛИВНО-ЭНЕРГЕТИЧЕСКИХ СИСТЕМ НА ОСНОВЕ ПРИРОДНЫХ И СИНТЕТИЧЕСКИХ ПОЛИМЕРОВ}

рассматриваемого варианта в виде множеств $\left\{L_{j}\right\}$ (рис. 3.5). Для составления материального баланса термодинамические системы задаются списками из $\mathrm{n}$ веществ $Y_{\mathrm{j}}$, где $\mathrm{j}=\{1 \ldots \mathrm{n}\}$, и $\mathrm{m}$ элементов $\mathrm{X}_{\mathrm{i}}$, где $\mathrm{i}=\{1 \ldots \mathrm{m}\}$ так, что любое j вещество $Y_{j}$ состоит только из $i$ элементов $X_{i} \quad c \quad$ учетом их стехиометрических коэффициентов (рис. 3.4).

В результате расчета получен массив данных, удовлетворяющий начальным условиям расчета и отображающий возможные изменения состояния систем в соответствии с изменением температурно-диффузионных характеристик процесса смесеобразования и сгорания топлива.

В качестве исходного состояния термодинамической модели Т системы (рис. 3.6) принимаются множество Lo из области равновесных состояний $\mathrm{Lp}_{\mathrm{p}}$, для которого значение функции Гиббса имеет максимальное значение.

При этом система $L_{0}$ располагается в центре многогранника, система L1 - одна из вершин многогранника материального баланса, условно принимается как первая вершина многогранника. Определив состав системы, на боковых сторонах призмы строятся диаграммы состояния двойных систем для определенных значениях температуры и давления линии изменения функции Гиббса при изменении состава систем. Определяется условие равновесия системы и искомый состав системы. 


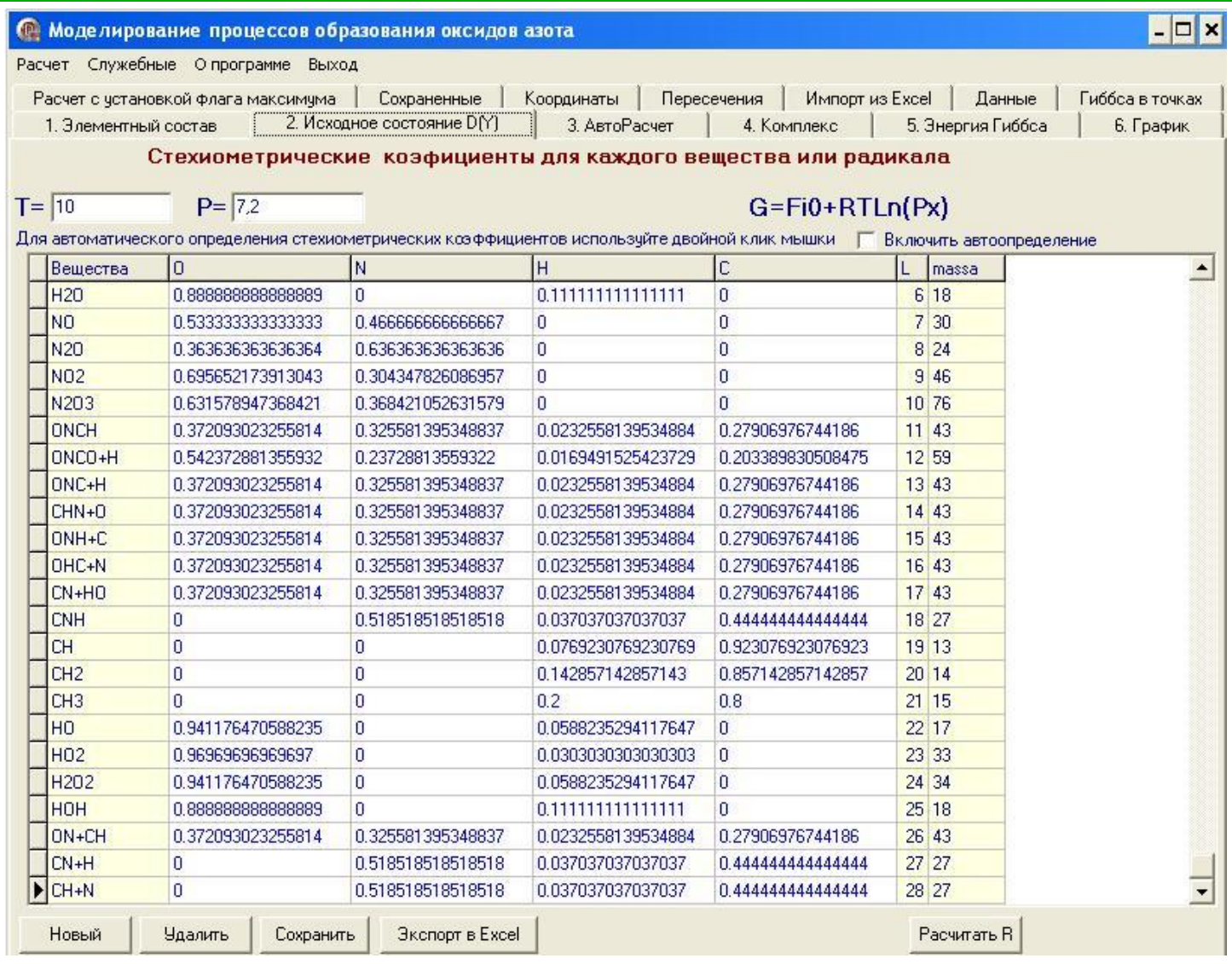

\section{Рис. 3.4. Расчет стехиометрических коэффициентов для веществ}

Программа «Моделирование» [31] предназначена для управления процессом моделирования, установки начальных значений процесса, управления результатами вычислительного эксперимента.

В качестве вычислительного сервера используется один из наиболее мощных и универсальных пакетов прикладных вычислительных программ MatLab. Сплайн-интерполяция используется для представления данных отрезками полиномов невысокой третей степени, что обеспечивает непрерывность первой и второй производных результата интерполяции в узловых точках. База данных обеспечивает хранение как промежуточных, так и окончательных результатов моделирования, структура программы позволяет полностью автоматизировать процесс моделирования процессов образования продуктов сгорания, лежащий в основе программного комплекса. 


\section{СТАБИЛИЗАЦИЯ СВОЙСТВ ТОПЛИВНО-ЭНЕРГЕТИЧЕСКИХ СИСТЕМ НА ОСНОВЕ ПРИРОДНЫХ И СИНТЕТИЧЕСКИХ ПОЛИМЕРОВ}

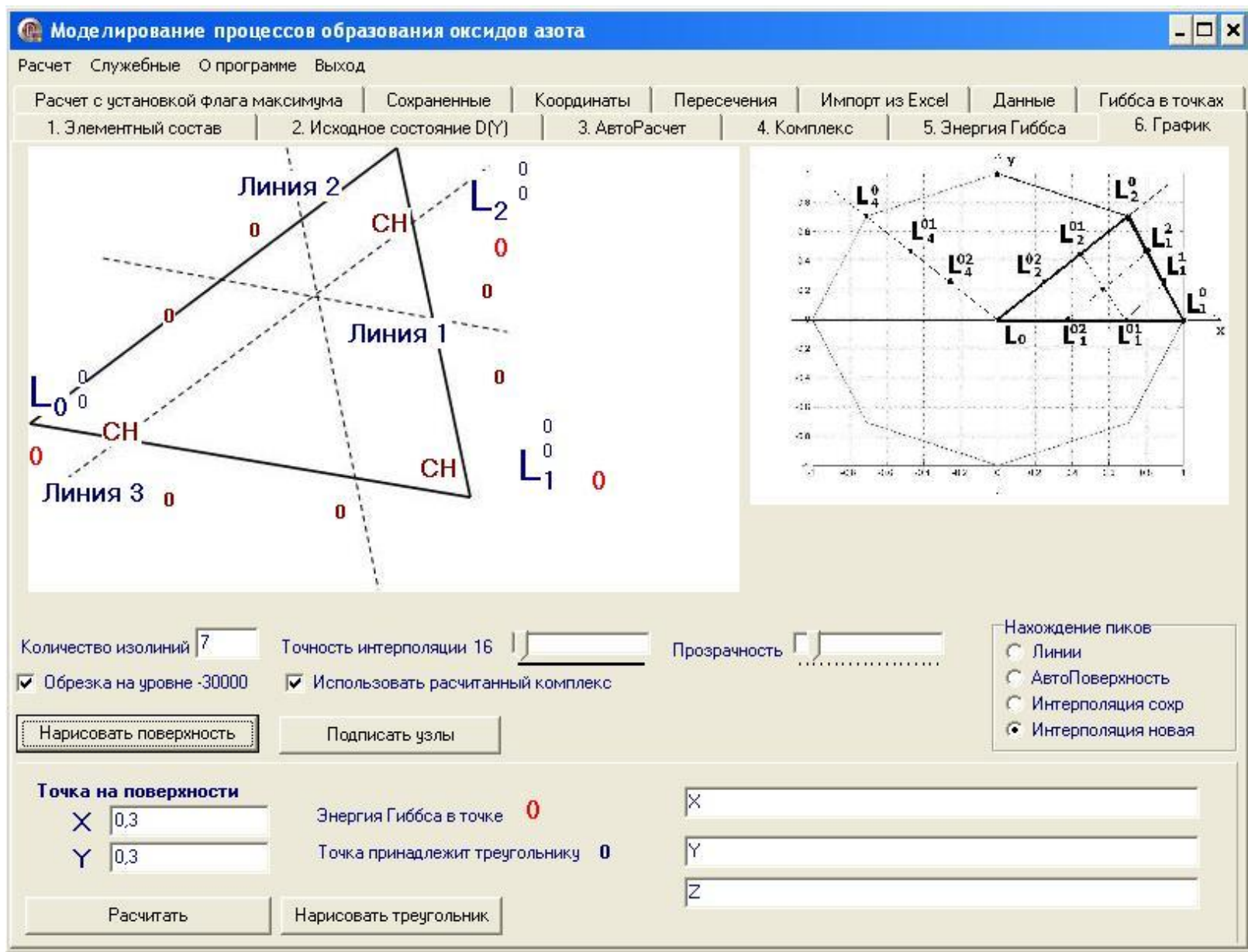

\section{Рис. 3.5. Инструментарий для графического отображения информации}

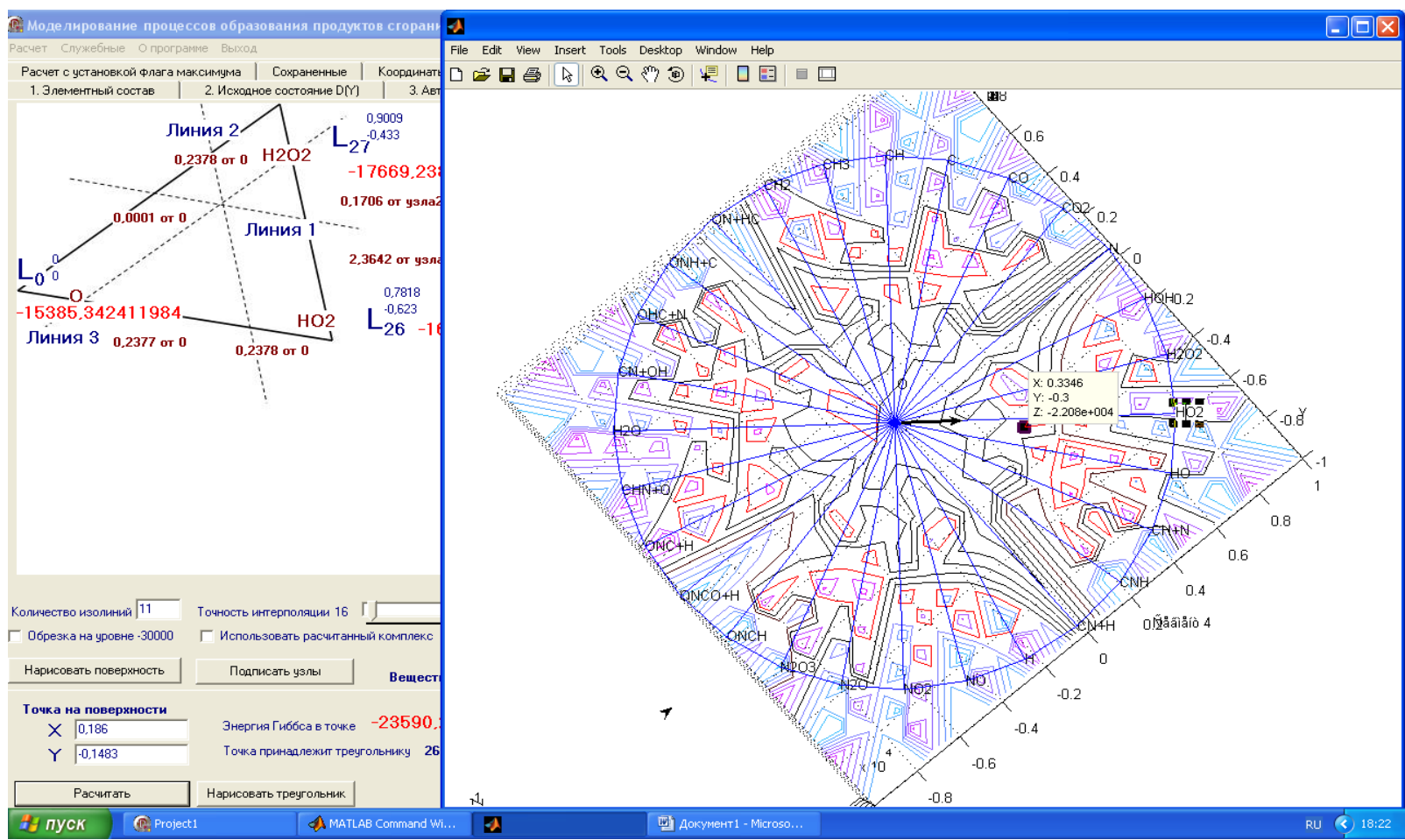

\section{Рис. 3.6. Исходное состояние термодинамической модели}




\section{СТАБИЛИЗАЦИЯ СВОЙСТВ ТОПЛИВНО-ЭНЕРГЕТИЧЕСКИХ СИСТЕМ НА ОСНОВЕ ПРИРОДНЫХ И СИНТЕТИЧЕСКИХ ПОЛИМЕРОВ}

Управление программным комплексом осуществляется через программу «Моделирование». Основные расчеты выполняются последовательно в следующих закладках: 1 - Элементный состав смеси, 2 - сходное состояние системы, 3 - Авторасчет, 4 - Комплекс, 5 - Функция Гиббса, 6 - Графические инструменты.

Перед началом моделирования необходимо указать химические элементы, из которых состоят вещества, присутствующие в смеси, а также определить их процентный состав из расчета 100 \%. Для этого предусмотрена закладка «Элементный состав смеси» (рис. 3.4). Эти данные являются исходным состоянием системы. Далее, необходимо в закладке 2 «Исходное состояние» указать вещества, исследуемые в системе, а также установить температуру и давление, при которых происходят процессы образования продуктов сгорания. Процесс рассматривается при постоянных объеме и температуре и заданном числе элементов - C, H, N, О. Для добавления вещества в систему необходимо нажать кнопку «Новый» и в появившемся окне ввести английскими буквами химическое название вещества. Здесь же можно проставить условный номер узла L в многоугольнике состояния. Решение задачи определения максимальных состояний каждого вещества в системе реализовано в закладке 3 «Авторасчет». В основе решения лежит численный метод решения оптимизационных задач - метод линейного программирования. При этом подготовленные данные в виде матриц передаются в MatLab, где применяется автоматизированный в системе MatLab метод linprog. Если при формировании комплекса установить галочку «Рассчитать энергию Гиббса», то при формировании комплекса одновременно будет произведен расчет энергии Гиббса. В закладке 6 представлены инструментарии для графического отображения результатов расчета (рис. 3.5).

Графические результаты моделирования представлены поверхностью над многоугольником, на котором указаны, какие именно вещества находятся в 118 
узлах и в центре модели. Удобно рассматривать проекцию этой поверхности на плоскость (рис. 3.7).

Модель переведена на алгоритмический язык и реализована в виде программного комплекса. В программном комплексе учтено, что термодинамическая модель позволяет исследовать влияние различных факторов: температуры и давления, условий смесеобразования, наличия диффузии в зонах реакций, на образование предельных концентраций искомых веществ, построить область оптимальных значений регулировочных параметров, влияющих на уменьшение концентрации токсичных компонентов, оценить действие различных режимов эксплуатации двигателей сгорания первый градиент функции Гиббса.

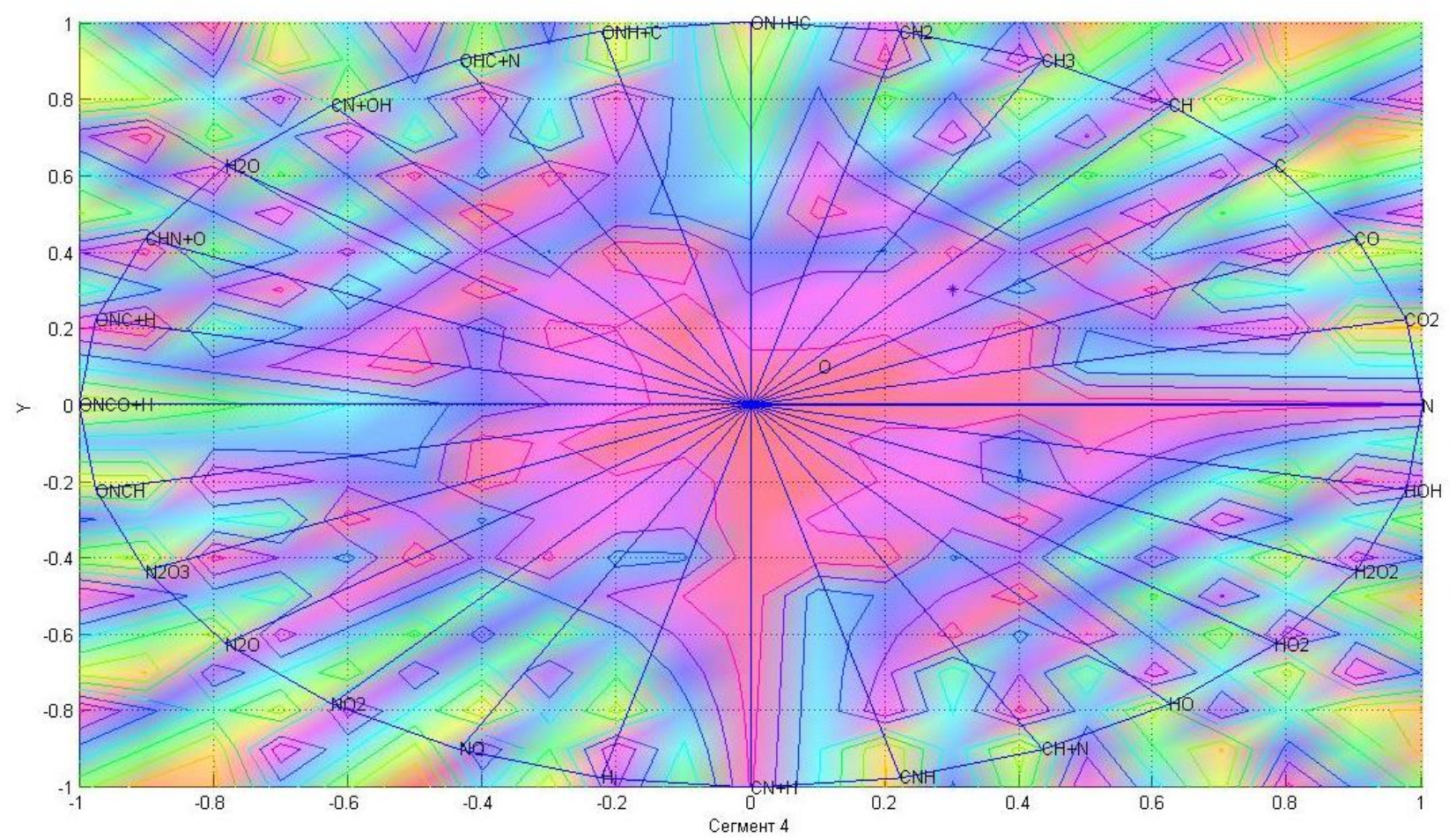

Рис. 3.7. Графическое отображения результатов расчета

Итоговая реакция процесса: $\mathrm{O}_{2}+\mathrm{N}_{2} \rightarrow 2 \mathrm{NO}$. Горение топлива представляется как механическое и тепловое динамическое равновесие последовательных, обратимых и параллельных химических реакций: системы, 


\section{СТАБИЛИЗАЦИЯ СВОЙСТВ ТОПЛИВНО-ЭНЕРГЕТИЧЕСКИХ СИСТЕМ НА ОСНОВЕ ПРИРОДНЫХ И СИНТЕТИЧЕСКИХ ПОЛИМЕРОВ}

состоящей из исходных веществ, и системы $\mathrm{D}_{\text {к., }}$ состоящей из конечных веществ - продуктов сгорания.

Если в процессе вещество может образоваться в разных формах, то сначала образуется наименее устойчивая форма, которая затем может превратиться в более устойчивую, проходя через формы промежуточной устойчивости. Эта закономерность объясняет образование метастабильных модификаций, которые в отсутствие более устойчивой фазы могут существовать неопределенно долго. Менее устойчивая форма обладает не только большим давлением паров, но и большей растворимостью, чем более устойчивая. Способность многих веществ находиться в метастабильном состоянии имеет большое практическое значение. Лимитирующей стадией горения является стадия преобразования азотсодержащих веществ. На диаграмме системы исходного состояния веществ представлены возможно достижимые состояния с максимальными концентрациями веществ.

Таким образом, анализ термодинамической модели $T$ процесса образования продуктов сгорания начинается в направлении от исходного состояния - системы множеств $\mathrm{L}_{0}$ и $\mathrm{L}_{1}$, к равновесному состоянию первого минимума функции Гиббса - области активных центров $A_{2}\left[\mathrm{~L} 25\{\mathrm{OH}\}, \mathrm{L}_{26}\left\{\mathrm{HO}_{2}\right\}\right.$, $\left.\mathrm{L}_{27}\left\{\mathrm{H}_{2} \mathrm{O}_{2}\right\}, \quad \mathrm{L}_{28}\{\mathrm{HOH}\}\right], \quad$ в направлении множества $\mathrm{L}_{26} \quad\left\{\mathrm{HO}_{2}\right\}, \quad$ где активированные центры систем $\left\{\mathrm{HO}_{2}\right\},\{\mathrm{HOH}\},\left\{\mathrm{H}_{2} \mathrm{O}_{2}\right\}$ формируют зону стабильных равновесных состояний (уровень замкнутых изолиний функции Гиббса, координата точки на поверхности $\mathrm{x}=0,3346$ и у=-0,3, рис. 3.6).

Используя разработанную программу, по установленному алгоритму расчета определяется фазовое равновесие систем области активных центров $A_{2}$ - множество $\left\{Z_{11}\right\}$, в котором наблюдается локальное равновесие систем L25, L26, L27, L28 (состояние на поверхности показано стрелкой, рис. 3.6). Состав множества $\left\{Z_{11}\right\}$ соответствует концентрации веществ равновесного состояния систем области активных центров А2, которому соответствует значение функции Гиббса $-\Phi_{p 1}$. В направлении второго минимума функции Гиббса - 
области активных комплексов $K_{1}\left[\mathrm{~L}_{16}\{\mathrm{OCNH}\}, \mathrm{L}_{15}\{\mathrm{ONCO}+\mathrm{H}\}, \mathrm{L}_{14}\{\mathrm{ONC}+\right.$ $\left.\mathrm{H}\}, \mathrm{L}_{13}\{\mathrm{CHN}+\mathrm{O}\}\right]$, образуется несколько локальных зон равновесия фаз, сдвигая равновесное состояние систем в сторону множества L15 $\{\mathrm{ONCO}+\mathrm{H}\}$. Исходной точкой в расчетах является множество $\left\{Z_{21}\right\}$, которое определяется пересечением равновесного уровня функции Гиббса $\Phi_{p l}$ с вектором градиента скорости убывания функции Гиббса $\Phi_{15}$ множества $\mathrm{L}_{15}, \max \{\mathrm{ONCO}+\mathrm{H}\}$. Далее по установленному алгоритму определяется фазовое равновесие систем области систем активных комплексов $K_{1}$ - множество $\left\{Z_{22}\right\}$ (координата точки на поверхности $\mathrm{x}=-0,5027$ и $\mathrm{y}=-0,07927$, рис. 3.8) и рассматривается локальное равновесие множеств $\left\{Z_{21}\right\}$ и $\left\{Z_{22}\right\}$.

В итоге, решая систему уравнений фазового равновесия для этих множеств, получают состав множества $\left\{\mathrm{Z}_{2}\right\}$, которому соответствует значение функции Гиббса $-\Phi_{p 2}$.

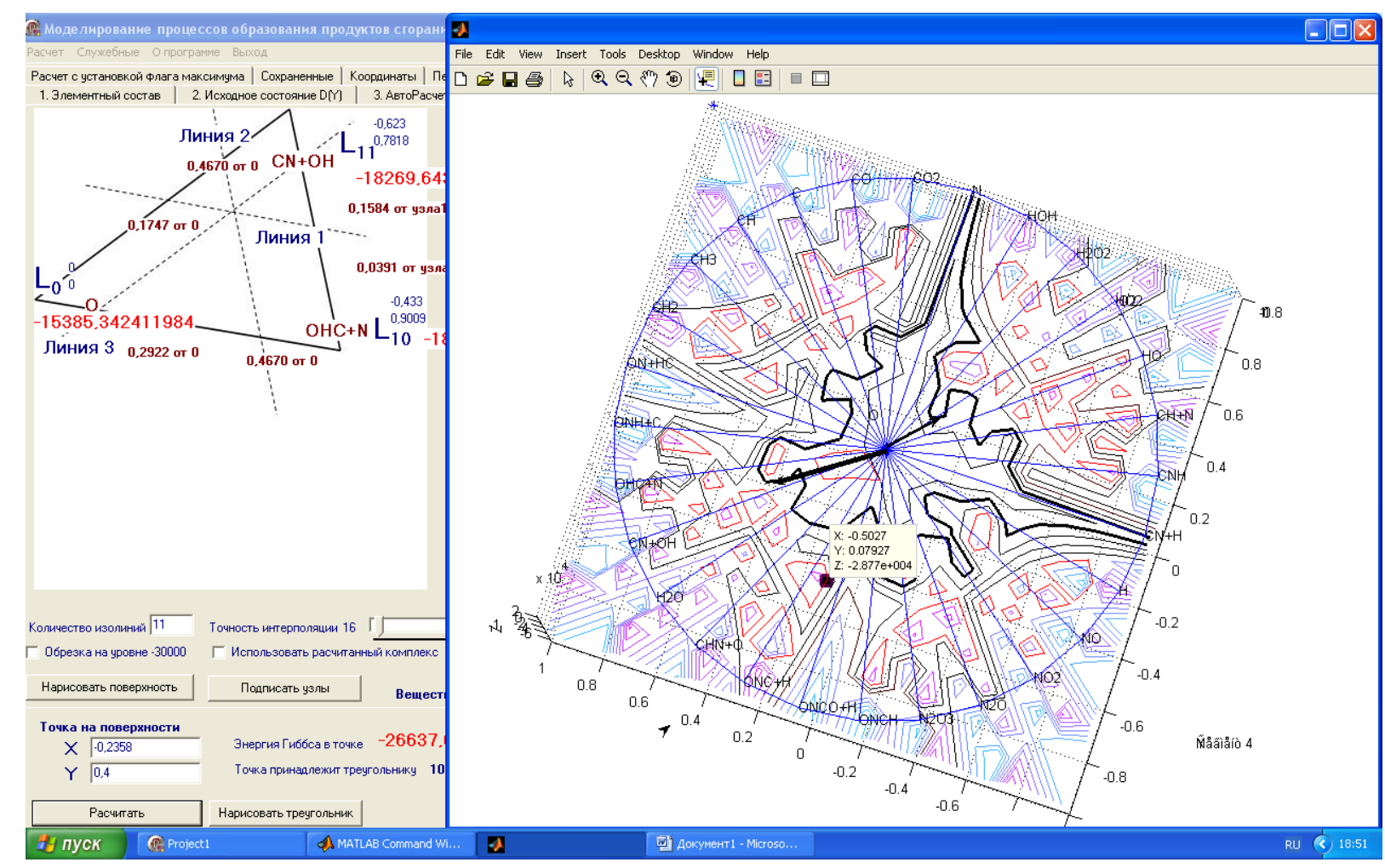

Рис. 3.8. Термодинамическая модель процесса образования продуктов сгорания - второй градиент функции Гиббса 
В направлении третьего и четвертого градиента функции Гиббса модели рассматривается аналогично развитие процесса деструкции топливовоздушной смеси в области активных комплексов $K_{2}[\mathrm{~L} 8\{\mathrm{ON}+\mathrm{HC}\}, \mathrm{L} 9\{\mathrm{ONH}+\mathrm{C}\}$, $\left.\mathrm{L}_{10}\{\mathrm{OHC}+\mathrm{N}\}, \mathrm{L}_{11}\{\mathrm{CN}+\mathrm{OH}\}\right]$ и в области систем конечного состояния $T_{\kappa}\left[\mathrm{L}_{17}\left\{\mathrm{~N}_{2} \mathrm{O}_{3}\right\}, \mathrm{L}_{18}\left\{\mathrm{~N}_{2} \mathrm{O}\right\}, \mathrm{L}_{19}\left\{\mathrm{NO}_{2}\right\} \mathrm{L}_{20}\{\mathrm{NO}\}\right]$, соответственно (рис. 3.9).

Равновесный уровень $\Phi_{p 4}$ можно считать устойчивым равновесным состоянием термодинамической системы $T$, которое определяет состав продуктов сгорания топливно-воздушной смеси.

Анализ распределения уровней равного потенциала термодинамической модели в зависимости от значений угла опережения впрыскивания топлива проводился по разработанной методики термодинамического анализа процесса сгорания топливо-воздушной смеси. Используя предложенную методику расчета, были построены диаграммы состояния, определяющие состав отработавших газов в зависимости от времени, отводимого на смесеобразование и сгорание топлива, организации процесса сгорания топлива - значений угла опережения и давления впрыскивания топлива.

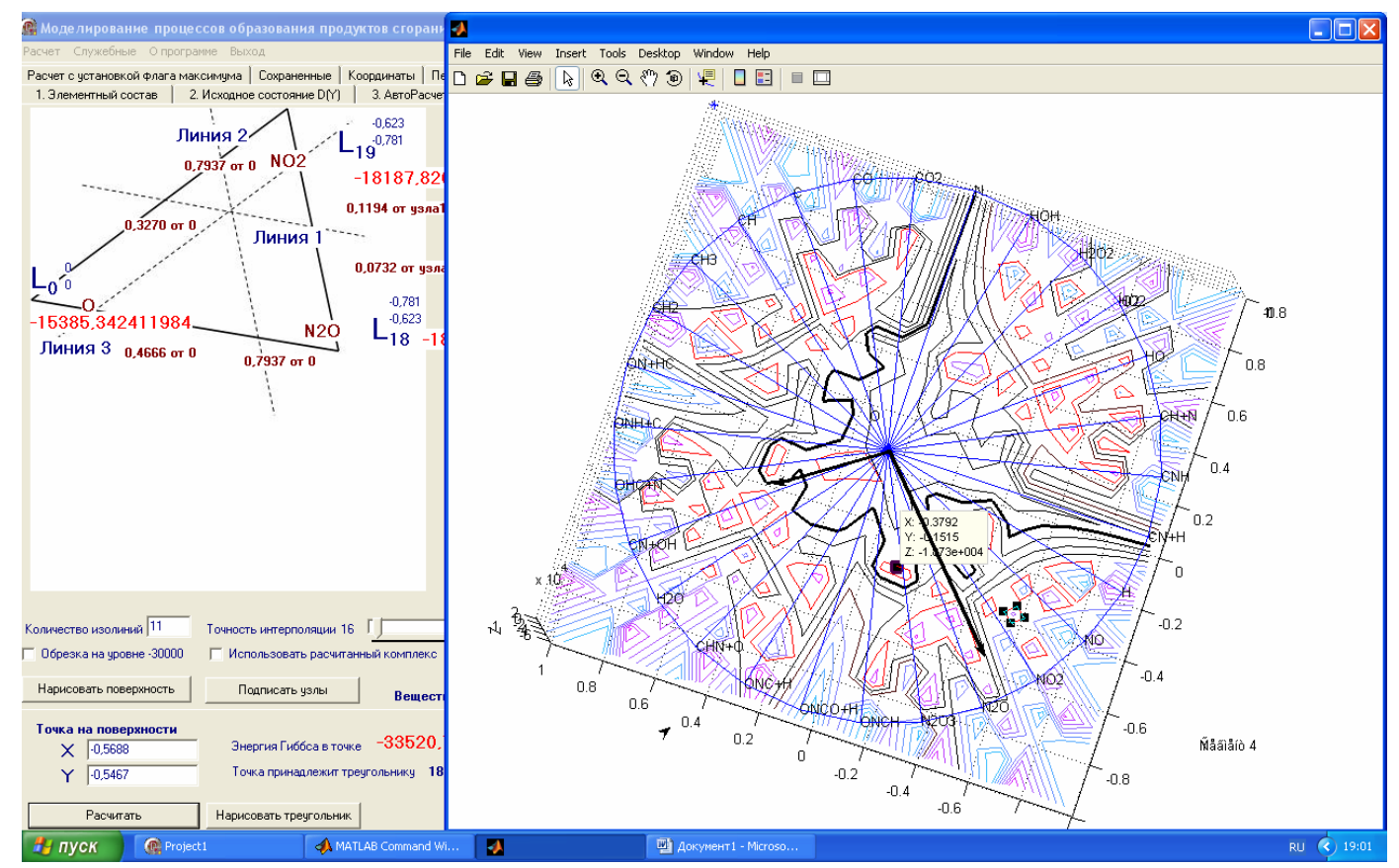

Рис. 3.9. Термодинамическая модель процесса образования продуктов сгорания - четвертый градиент функции Гиббса 


\section{СТАБИЛИЗАЦИЯ СВОЙСТВ ТОПЛИВНО-ЭНЕРГЕТИЧЕСКИХ СИСТЕМ НА ОСНОВЕ ПРИРОДНЫХ И СИНТЕТИЧЕСКИХ ПОЛИМЕРОВ}

Исследованиями установлено, что максимально возможный уровень, так же как и равновесный уровень функции Гиббса не достигаться в реальных условиях сгорания. Разрешимый термодинамический уровень определяется временем, отводимым на смесеобразование и сгорание топлива в дизеле. Весь процесс сгорания разбивается на временные интервалы $\tau 0, \tau 1, \tau 2$ и $\tau 3-$ время задержки воспламенения, период возрастания температур до максимальных значений и период наблюдения температур и от максимальных значений до конца такта расширения, которые определены по результатам индицирования рабочего процесса двигателя (табл.3.4).

Временной интервал $\tau 0$ значительно меньше термодинамически возможного времени $\varphi$ достижения множества $\left\{\mathrm{L}_{1}\right\}$, что ограничивает развитие процесса в области первого градиента равновесного уровня функции Гиббса $\Phi_{p 1 .}$ Таким образом, достижимое состояние будет множество $\left\{\mathrm{F}_{1}\right\}$, которому соответствует уровень функции Гиббса $Ф$ д 1 (координата точки $\mathrm{x}=0,186$ и

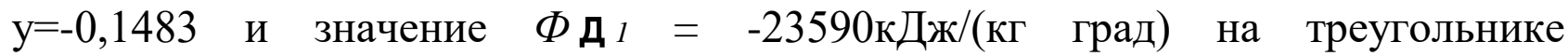
материального баланса, рис. 3.6) и смещает развитие процесса в направлении второго градиента.

Таблица 3.4

Соответствие временного интервала цикла дизеля $\tau_{i}$ и временного интервала, определяемого по термодинамической модели $\varphi_{i}$

\begin{tabular}{|c|c|c|c|c|c|c|}
\hline \multirow{2}{*}{\multicolumn{2}{|c|}{$\begin{array}{c}\text { Временной } \\
\text { интервал }\end{array}$}} & \multicolumn{5}{|c|}{$\begin{array}{c}\text { Интервалы времени для номинального режима и угла } \\
\text { опережения впрыска } \mathrm{Q}=20 \text { град ПКВ до ВМТ }\end{array}$} \\
\hline & & 1 & 2 & 3 & 4 & сумма \\
\hline$\varphi_{i}$ & MM & 0,2378 & 0,4670 & 0,4786 & 0,7937 & 1,9771 \\
\hline \multirow[t]{2}{*}{$\tau_{i}$} & млс & 1,4285 & 5 & 4,1515 & 3,0303 & 13,6103 \\
\hline & & \multicolumn{5}{|c|}{ Относительные значения } \\
\hline$\varphi_{i}$ & отн.ед & 0,1203 & 0,2362 & 0,2421 & 0,4015 & 1 \\
\hline \multirow[t]{2}{*}{$\tau_{i}$} & отн.ед & 0,10496 & 0,3674 & 0,3050 & 0,2227 & 1 \\
\hline & & \multicolumn{5}{|c|}{ При условии достижения локального равновесия } \\
\hline \multirow[b]{2}{*}{$\varphi_{i i}$} & MM & 0,2378 & 0,2351 & 0,4148 & 0,7937 & 1,6814 \\
\hline & отн.ед & 0,1414 & 0,1398 & 0,2467 & 0,4721 & 1 \\
\hline$\tau_{i}$ & отн.ед & 0,10496 & 0,3674 & 0,3050 & 0,2227 & 1 \\
\hline
\end{tabular}




\section{СТАБИЛИЗАЦИЯ СВОЙСТВ ТОПЛИВНО-ЭНЕРГЕТИЧЕСКИХ СИСТЕМ НА ОСНОВЕ ПРИРОДНЫХ И СИНТЕТИЧЕСКИХ ПОЛИМЕРОВ}

Время наблюдения максимальных температур цикла $\tau_{2}>\varphi 2$ и $\tau_{3}>\varphi 3$ или основного процесса сгорания не накладывают ограничения на развитие процесса сгорания. Поэтому термодинамически возможно достижение равновесного уровня в направлении второго и третьего градиента, однако равновесное состояние смещается из-за изменения исходного уровня функции Гиббса и достигается множество $\left\{\mathrm{F}_{2}\right\}$ в направлении второго градиента функции, которому соответствует уровень $Ф$ д 2. В направлении третьего градиента функции Гиббса достигается множество $\left\{\mathrm{F}_{3}\right\}$, которому соответствует уровень $\Phi$ д 3 (координата точки $\mathrm{x}=-0,2358$ и у $=0,4$ и значение $\Phi$ д $2=-26637$ кДж/(кг град) на треугольнике материального баланса (рис. 3.9). Процессу сгорания завершается на линии расширения, ему соответствует время $\tau_{4}=0,426$ усл.ед., что меньше термодинамически возможного времени $\varphi 4$, поэтому стабильный равновесный уровень в данной области недостижим, действительное равновесное состояние смещено в сторону множеств $\mathrm{L}_{11}\{\mathrm{NO}\}$ $\mathrm{L}_{12}\left\{\mathrm{~N}_{2} \mathrm{O}\right\}$. Достижимому равновесному состоянию со ответствует множество $\left\{\mathrm{F}_{4}\right\}$ и равновесным уровень $Ф \partial 4$ (координата точки $\mathrm{x}=-0,5688$ и $\mathrm{y}=-0,5467$ и значение $\Phi$ д $2=-3520$ кДж/(кг град). Анализ распределения уровней равного потенциала термодинамической модели позволяет установить зависимости изменения состава системы при заданных условиях смесеобразования и сгорания.

При увеличении угла опережения впрыскивания топлива по сравнению с оптимальным значением уменьшается временной интервал $\tau_{2}$, то есть разрешимый уровень функции Гиббса $\Phi_{p 2}$ не достигается, и достижимое состояние термодинамической системы сместится в сторону третьего градиента функции Гиббса. При этом увеличивается интервал наблюдения максимальных температур цикла 3. Таким образом, определяя достижимый уровень равного потенциала термодинамической модели сгорания топлива, устанавливаются 


\section{СТАБИЛИЗАЦИЯ СВОЙСТВ ТОПЛИВНО-ЭНЕРГЕТИЧЕСКИХ СИСТЕМ НА ОСНОВЕ ПРИРОДНЫХ И СИНТЕТИЧЕСКИХ ПОЛИМЕРОВ}

возможные концентрации продуктов сгорания в зависимости от изменения угла опережения впрыскивания топлива. Уменьшение установочного угла опережения взыскивания топлива сокращает время протекания подготовительных процессов сгорания топлива $\tau_{0}$, при этом достижимое состояние термодинамической системы сместится в сторону второго градиента функции Гиббса. Сокращается также время наблюдения максимальных температур $\tau_{1}$ и $\tau_{2}$, таким образом, увеличивается продолжительность временного интервала соответствующего четвертому градиенту функции Гиббса. Сокращение времени наблюдения максимальных температур определяет уменьшение образования оксидов азота, но при этом увеличивается количество несгоревших углеводородов (рис. 3.10).

Разработанная модель позволяет исследовать влияние изменение давления начала впрыскивания топлива на образование продуктов сгорания топлива (рис. 3.11). Разработан алгоритм расчета концентраций оксидов азота в отработавших газах и методология минимизации токсичных веществ [62, с. 37].

Из построенных диаграмм состояния следует, что теоретически можно существенно снизить выход оксидов азота, наложив ограничения на процесс организации сгорания топлива, фактически создав существование зон недостатка кислорода в начальной стадии горения, либо на линии расширения и наблюдения максимальных температур. 


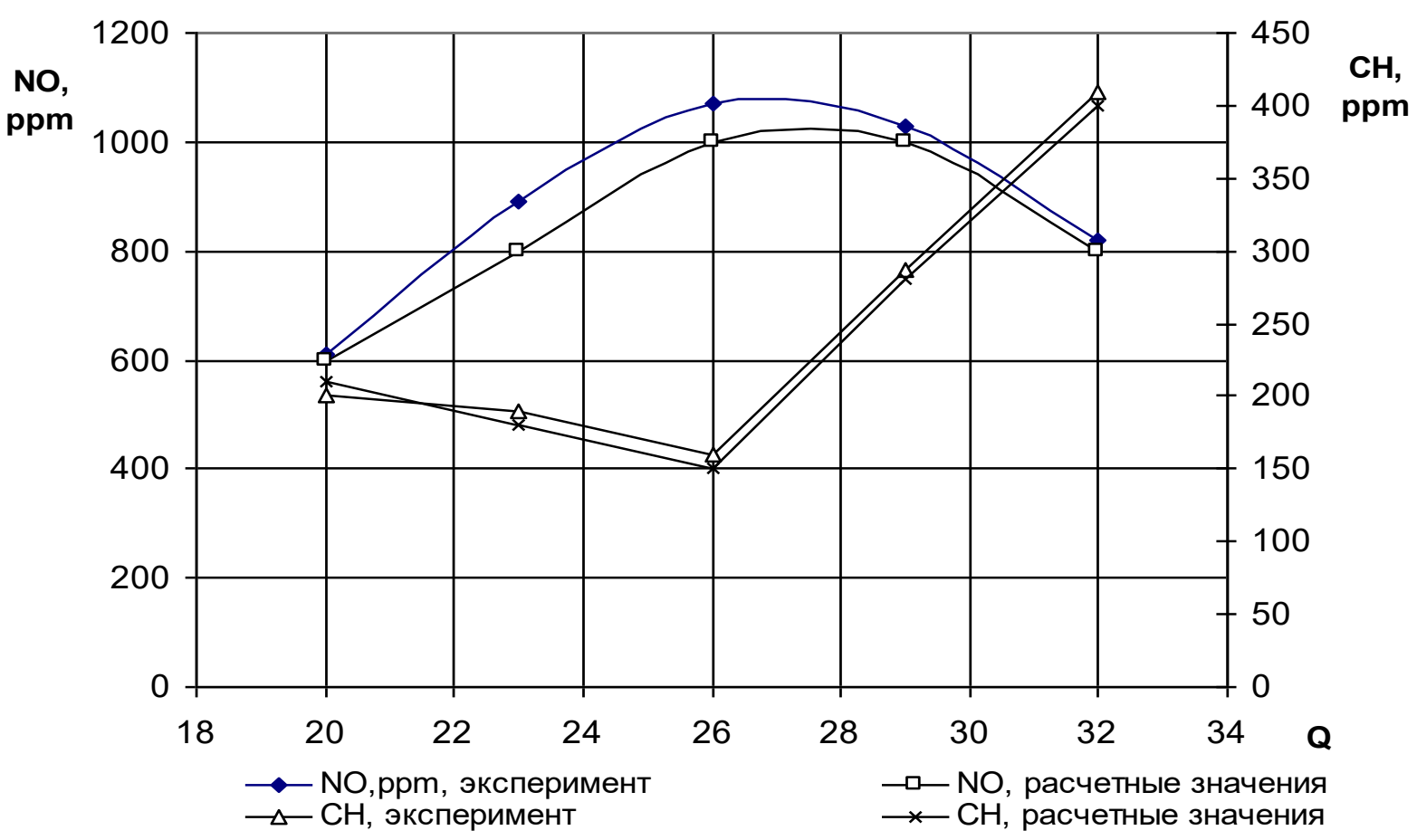

Рис. 3.10. Изменение состава отработавших газов дизеля Д-243 в зависимости от значений угла опережения впрыска топлива n=2200

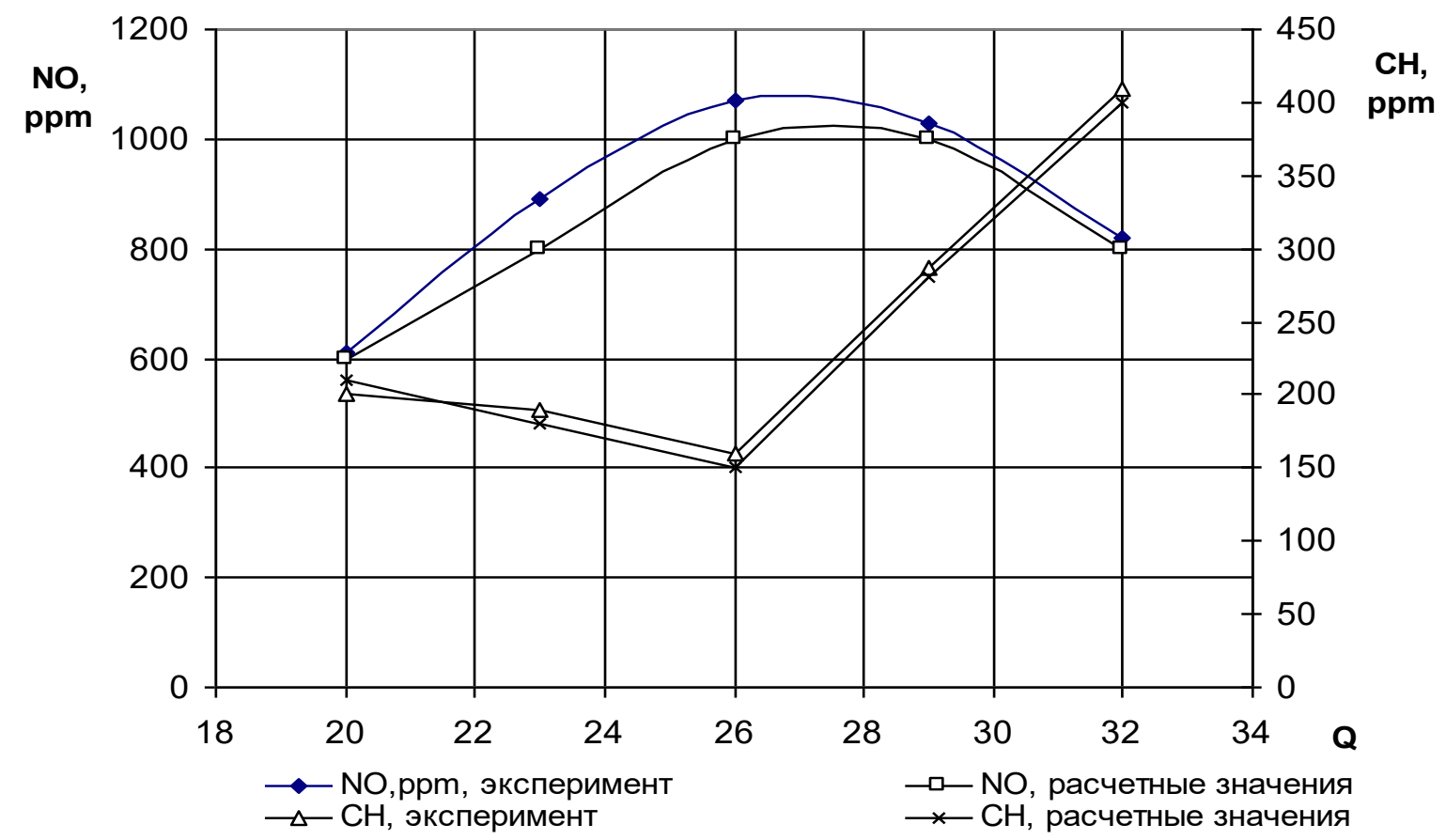

Рис. 3.11. Изменение состава отработавших газов дизеля Д-243 в зависимости от значений угла опережения впрыска топлива n=2200 


\section{СТАБИЛИЗАЦИЯ СВОЙСТВ ТОПЛИВНО-ЭНЕРГЕТИЧЕСКИХ СИСТЕМ НА ОСНОВЕ ПРИРОДНЫХ И СИНТЕТИЧЕСКИХ ПОЛИМЕРОВ}

Практически эти ограничения соответствуют неполному сгоранию топлива и совпадают с результатами многочисленных исследований зависимости содержания оксидов азота в ОГ от условий смесеобразования. Кроме того, рассматриваемая термодинамическая модель позволяет изучить зависимость изменения концентрации оксидов азота в отработавших газах от скорости развития процесса сгорания топлива или образования конечных продуктов сгорания $-\mathrm{CO}_{2}$, сажи или $\mathrm{CH}$ - при рассмотрении градиента концентрации.

Поэтому, первичные - режимно-технологические мероприятия для снижения образования термических $\mathrm{NO}_{x}$ основаны на воздействии на один или несколько факторов в зоне максимальной генерации $\mathrm{NO}_{x}$ для создания специальных условий в факеле горения, приводящих к восстановлению образовавшихся оксидов азота до молекулярного азота, как это происходит, например, при ступенчатом сжигании топлива. 


\section{ГЛАВА 4.}

\section{МЕТОДОЛОГИЯ ДЕСТРУКЦИИ СИНТЕТИЧЕСКИХ И ПРИРОДНЫХ ПОЛИМЕРНЫХ ОТХОДОВ}

\section{1 Теоретические аспекты утилизации полимерных отходов}

Бытовые и промышленных полимерные отходы можно рассматривать как потенциальные возобновляемые энергетические ресурсы, с помощью которых можно решить ресурсосберегающую проблему, минимизировать техногенное давление на атмосферный воздух, поверхностные воды, почву, стабилизировать качество техногенных экосистем. Полимерные отходы, содержащие преимущественно углерод, по своему происхождению могут быть органогенными: бумага, картон, пищевые или растительные массы, активный ил, осадки бытовых сточных вод или синтетическими: пластические массы, текстиль и другие. Наибольшую опасность для жизнедеятельности людей представляют крупнотоннажные техногенные отходы нефтехимической (II класса опасности), химической, горнодобывающей, целлюлозной, деревоперерабатывающей промышленности с длительным периодом разложения. Синтетические полимерные отходы относятся к 5 классу опасности. Однако увеличение объёма потребления синтетических полимерных материалов ведет к накоплению не свойственных природным экосистемам неразлагающихся биологическими объектами отходов и складируются на полигонах, что приводит к отчуждению земель агропромышленного комплекса, деградации почв, ландшафтов, загрязнению объектов окружающей среды. Низкая степень использования таких отходов в России связана с их неоднородным химическим составом, нестабильностью физико-химических свойств продуктов деструкции отходов (твердость, прочность, легкость, долговечность), и высокими энергетическими затратами на деструкцию 


\section{СТАБИЛИЗАЦИЯ СВОЙСТВ ТОПЛИВНО-ЭНЕРГЕТИЧЕСКИХ СИСТЕМ НА ОСНОВЕ ПРИРОДНЫХ И СИНТЕТИЧЕСКИХ ПОЛИМЕРОВ}

полимерных связей. В отличие от синтетических полимерных отходов техногенные органогенные отходы содержат устойчивые биополимеры: целлюлозу и лигнин, синтезируемые древесными и травянистыми растениями. Скорость поступления техногенных полимерных отходов во много раз превышает скорость их деструкции и отражается на биологической продуктивности природных экосистем и их стабильности. В природных экосистемах такие биополимеры подвергаются деструкции в течение длительного периода времени и включаются в естественный круговорот биогенных веществ.

Для получения дешевого и экологически безопасного возобновляемого энергетического сырья, повышения эффективности производства и рационального управления технологическими процессами разработана эффективная методология утилизации синтетических и природных полимерных отходов с использованием инновационных инструментариев утилизации углеродсодержащих отходов с получением полезных продуктов. В основе предлагаемой методологии оценку стабильности качества и безопасности природных и синтетических полимерных систем лежит принцип минимизации техногенного риска, замена природного сырья (биополимеров) на синтетические аналоги, а также минимизации тепловых и газообразных выбросов. Для достижения этих целей использовали инструментарии физикохимического анализа, мониторинга, моделирования, рационального использования природных энергетических ресурсов, утилизации бытовых и промышленных отходов.

Деструкцию синтетических и природных полимерных отходов, состав которых предопределятся функционированием природной почвеннобиотической экосистемой и получением полезных продуктов: композиционных материалов, биогаза и гумифицированной почвы проводится с использованием эффективных инструментариев. 


\section{СТАБИЛИЗАЦИЯ СВОЙСТВ ТОПЛИВНО-ЭНЕРГЕТИЧЕСКИХ СИСТЕМ НА ОСНОВЕ ПРИРОДНЫХ И СИНТЕТИЧЕСКИХ ПОЛИМЕРОВ}

Основными этапами технологии утилизации полимеров являются: идентификация отходов (анализ природы, состава и свойств); выбор инструментариев деструкции отходов; разработка рациональной технологической схемы получения полезных продуктов; оценка эффективности использования разработанной технологии.

\subsection{1 Идентификация полимерных отходов}

Синтетические полимеры, используемые для замены аналогов природного сырья при изготовлении широкого ассортимента полезных материалов: лаков и красок, пластмасс, пленок, волокон, шестерен, канатов, тары и других, после истечения срока эксплуатации попадают в виде отходов и складируются на полигонах. Рост объемов отходов приводит к увеличению площадей земельных угодий, отчуждаемых для их складирования, на которых они в течение длительного периода времени (около 80 лет) не подвергаются деструкции под действием внешних экологических факторов (термических, фотохимических, биологических и других) [63, с. 9]. Основной удельный вес в общей массе полимерных отходов занимают отходы на основе синтетического полимера - полиэтилентерефталата (ПЭТФ). В настоящее время в России объем его отходов превышают 10 млн. т / год [64, с. 25]. Почти 40\% изделий из пластмасс используется в качестве упаковочных материалов из-за своих универсальных эксплуатационных свойств легкости, прочности. В настоящее время объём перерабатываемых ПЭТФ отходов не превышает трёх процентов $[65,66]$.

Кроме синтетических полимеров около $45 \%$ техногенных отходов поступает в окружающую среду при переработке древесины и сельскохозяйственных культур и 8\% - в виде бытовых твердых отходов, содержащих биополимеры (рис.4.1). На долю технического лигнина приходится примерно 2\%. Отходы лигнина (около 350 тыс. т.) сжигаются, а остальные является потенциальным углеродсодержащим энергетическим 130 
ресурсом. Технический лигнин складируются на промышленных полигонах, высота которых достигает 50 м (терриконы), в которых под воздействием температуры, света, атмосферных осадков и других экологических факторов протекают химические или фотохимические реакции, что приводит к самовозгоранию терриконов при температуре воздуха плюс $35 \ldots 40^{0}$ С и выделением в атмосферный воздух летучих токсичных веществ и загрязнению прилегающих районов [66 - 68].

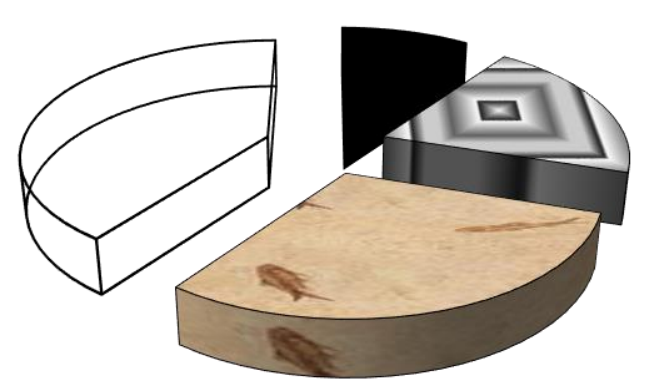

घ 1 2 2 प4

Рис. 4.1. Схема распределения биополимерных отходов: 1 - технический лигнин, 2 - твердые бытовые отходы, 3 - агропромышленные отходы,

\section{4 - промышленные отходы}

Содержание биополимеров в бытовых твердых отходах: пищевых массах, бумаге и картоне во много превышает (приблизительно 9 раз) содержание синтетических полимеров в виде текстиля и пластмасс (рис.4.2).

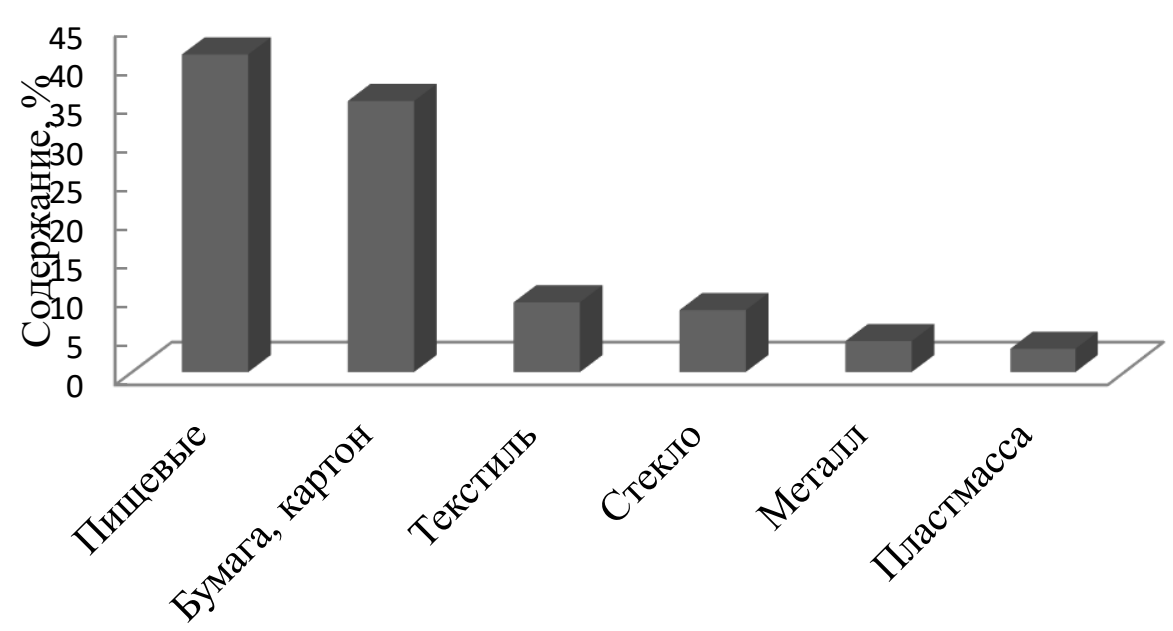

Рис. 4.2. Схема распределения твердых бытовых отходов 


\section{СТАБИЛИЗАЦИЯ СВОЙСТВ ТОПЛИВНО-ЭНЕРГЕТИЧЕСКИХ СИСТЕМ НА ОСНОВЕ ПРИРОДНЫХ И СИНТЕТИЧЕСКИХ ПОЛИМЕРОВ}

Наряду с техническим лигнином накапливается большое количество первичных и вторичных (кора, щепа, опилки, стружка) древесных некондиционных отходов (около 70 млн. тонн), содержащих целлюлозу и лигнин в связанном состоянии (лигноцеллюлоза), которые могут быть использованы как возобновляемые энергетические ресурсы. Преимуществом древесных отходов при получении тепловой энергии связано с отсутствием серы и невысокой зольности $(0,2 \ldots 1,7 \%)$, а недостатком - высокой влажностью $(30 \ldots 80 \%)$. Скорость утилизации биополимерных твердых отходов лимитирует прочные химические связи полимеров лигниноцеллюлозы.

\subsection{2 Состав и свойства синтетических и биополимерных отходов}

Идентификация химического состава, структуры, молекулярной массы, наличия функциональных групп и инструментариев синтеза необходима при выборе инструментариев деструкции полимерных отходов и получении полезного продукта деструкции. Стабильность синтетических полимерных отходов к воздействию физико-химических: температуры, кислорода, света, радиации, влажности, агрессивных химических агентов, и физикомеханических факторов зависит от свойств исходного полимерного материала, способа получения. В промышленности ПЭТФ обычно синтезируют двух стадийным способом: переэтерификацией диметирефталата (DMT) этиленгликолем с последующей поликонденсацией полученного на первой стадии дигликольтерефталата (DGT) [63]. Физико-химические свойства ПЭТВ зависят от химического состава и структуры элементарного звена макромолекулы (рис. 4.3), соотношения свободных функциональных гидроксильных $(-\mathrm{OH})$ или карбоксильных $(-\mathrm{COOH})$ групп [30].

Синтетический полиэтилентерефталат - твердое вещество белого цвета без запаха, плотностью $1,38 \ldots 1,40$ г $/ \mathrm{cm}^{3}\left(20^{\circ} \mathrm{C}\right)$, температура $\mathrm{t}_{\text {размяг. }} 245 \ldots 248^{\circ} \mathrm{C}$, температура стеклования $70 \ldots 80^{\circ} \mathrm{C}$, не растворяется в воде и органических 
растворителях, сравнительно устойчив к действию разбавленных растворов кислот, обладает высокой прочностью к истиранию и многократным деформациям при растяжении и изгибе, низкой гигроскопичностью, хороший диэлектрик (тангенс угла диэлектрических потерь при 1 Мгц - 0,013...0,015), устойчив к действию световых и рентгеновских лучей, обладает низкой вязкостью расплава (средний показатель текучести расплава при плюс $280^{\circ} \mathrm{C}$ равен 7,5г/10мин). Физико-химические и физико-механические показатели качества стабильны в диапазоне рабочих температур $60 \ldots 170^{\circ} \mathrm{C}$.

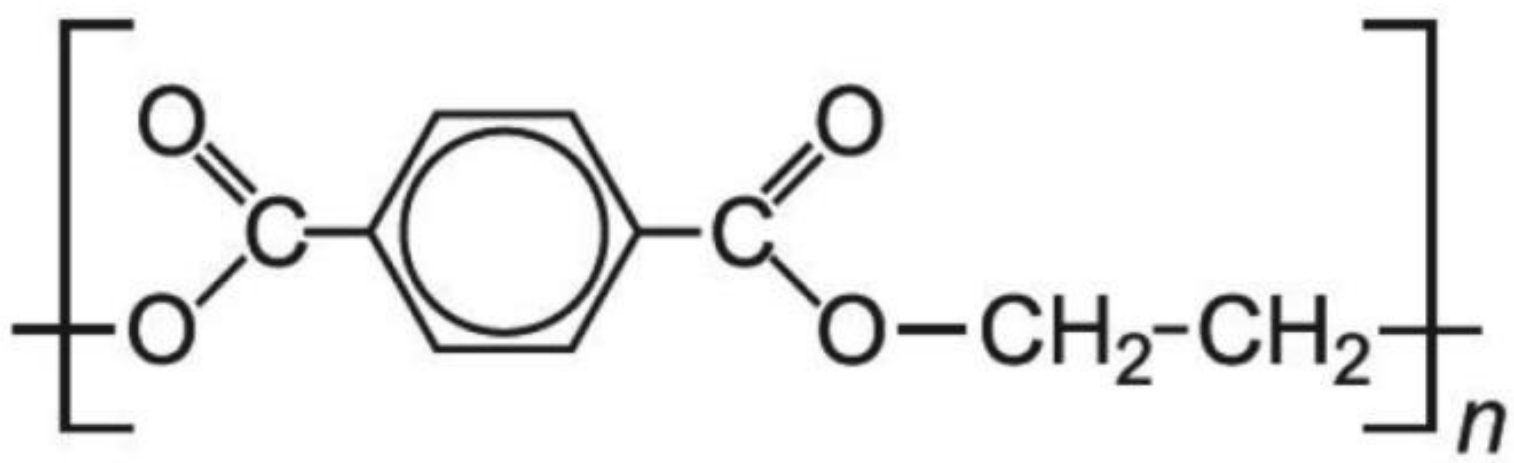

Рис. 4.3. Структура звена макромолекулы полимера ПЭТФ

Качественный и количественный состав природных полимеров целлюлозосодержащих отходов зависит от экологических, генетических, физиологических, биохимических факторов, жизненного цикла растений, соотношения лигнина и целлюлозы в них и во многом предопределяет скорость деструкции в почвенно-биотическом комплексе. Обобщенный элементарный состав древесных отходов представляет собой: углерод (C) - 49,5\%, кислород $(\mathrm{O})-44,1 \%$, водород $(\mathrm{H})-6,3 \%$ и азот $(\mathrm{N})-0,1 \%$. Эти элементы входят в состав сложных и простых химических соединений, образующих клетки, ткани, органы живых древесных [69, с. 7] и травянистых растений. В природных экосистемах биополимеры лигнин - целлюлоза медленно разлагаются под действием лигнинолитичеких ферментов (лакказы и пероксидазы) грибов- 


\section{СТАБИЛИЗАЦИЯ СВОЙСТВ ТОПЛИВНО-ЭНЕРГЕТИЧЕСКИХ СИСТЕМ НА ОСНОВЕ ПРИРОДНЫХ И СИНТЕТИЧЕСКИХ ПОЛИМЕРОВ}

базидиомицетов (Polystictus versicolor, Stereum hirsutum, Pleurotus ostreatus Ganoderma applanatum, Polyporus adustus, Armillaria mellea), живущих как на живых, так и на мёртвых деревьях с образованием промежуточных веществ, которые участвуют в гумификации или минерализации почв. При этом образуются подвижные биогенные вещества в виде минеральных солей, используемых растениями как элементы питания сульфатов $\left(\mathrm{SO}_{4}{ }^{2-}\right)$, нитритов $\left(\mathrm{NO}_{2}^{-}\right)$, нитратов $\left(\mathrm{NO}_{3}^{-}\right)$, или газообразных веществ водорода $\left(\mathrm{H}_{2}\right)$, аммиака $\left(\mathrm{NH}_{3}\right)$, углекислого газа или диоксида углерода $\left(\mathrm{CO}_{2}\right)$, метана $\left(\mathrm{CH}_{4}\right)$, азота $\left(\mathrm{N}_{2}\right)$, сероводорода $\left(\mathrm{H}_{2} \mathrm{~S}\right)$. Промежуточные и гумусовые вещества адсорбируются на минеральной составляющей почвы с образованием органоминеральных коллоидов [71, с. 66].

Химический состав травянистой и древесной биомассы представляет собой сложную многокомпонентную систему (рис. 4.4).

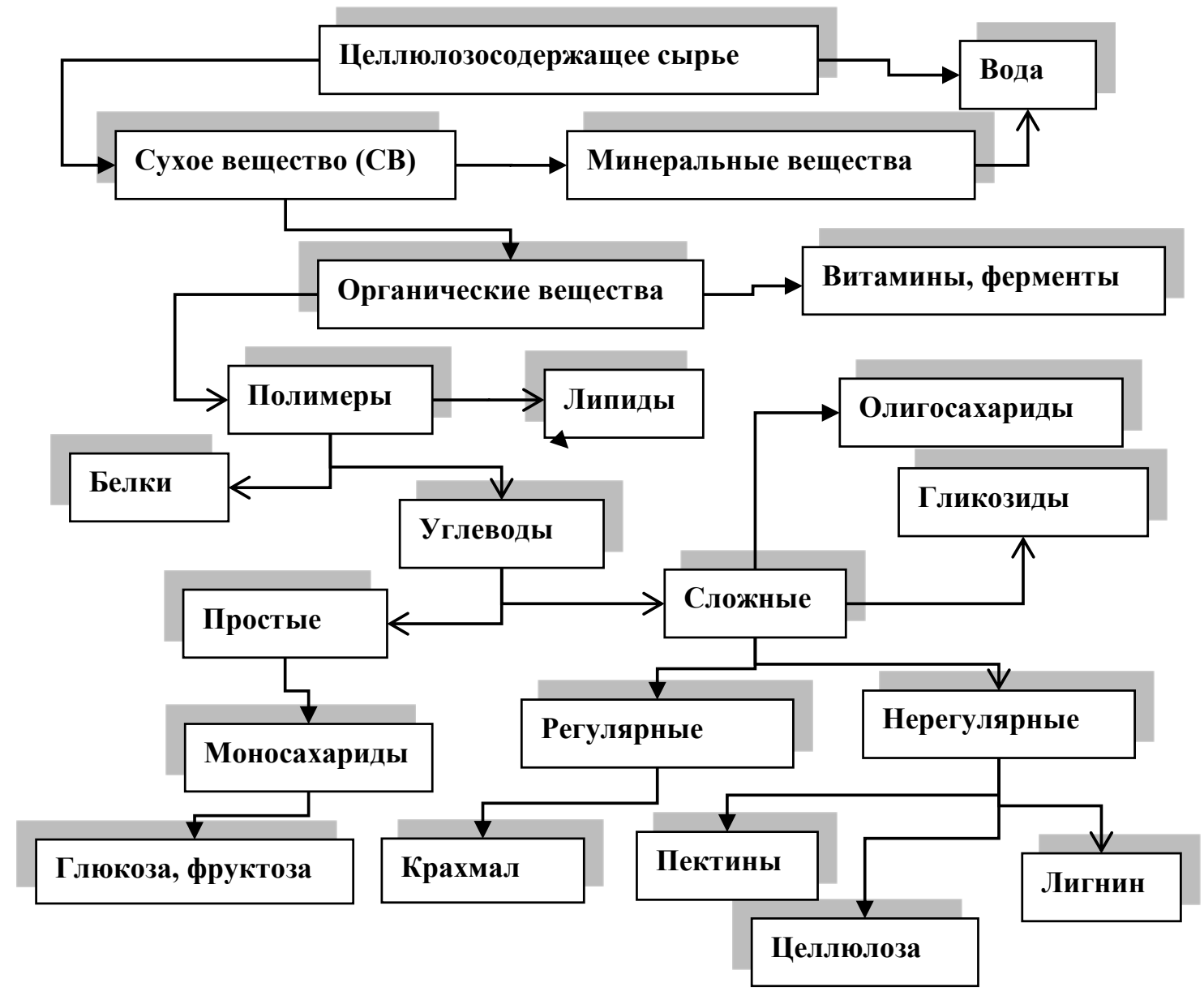

Рис. 4.4. Состав целлюлозосодержащего сырья 


\section{СТАБИЛИЗАЦИЯ СВОЙСТВ ТОПЛИВНО-ЭНЕРГЕТИЧЕСКИХ СИСТЕМ НА ОСНОВЕ ПРИРОДНЫХ И СИНТЕТИЧЕСКИХ ПОЛИМЕРОВ}

Белки имеют полимерную структуру, состоящую из остатков аминокислот с молекулярной массой 6000..1000000, легко минерализуются под действием ферментов микроорганизмов. К полимерным макромолекулам углеводов относятся полисахариды: крахмал, целлюлоза, гемицеллюлоза, пектины. Макромолекулы целлюлозы состоят из остатков D-глюкозы и представлены в виде пучков, волокон диаметром приблизительно 20 нм. Лигнин (протолигнин) (лат. lignum, ligni) ароматический сетчатый полимер с молекулярной массой примерно $4000 \ldots 50000000$ усл. ед., размером макромолекул 0,001 ... 0,1 мм, связан с полисахаридами сложноэфирными, гликозидными или простыми эфирными связями, обеспечивая высокую прочность и низкую проницаемость клеточных стенок, входит в состав почти всех наземных растений и по распространенности среди природных высокомолекулярных соединений уступает только полисахаридам (целлюлозе). Природный лигнин (протолигнин) связан с целлюлозой и гемицеллюлозой в единый комплекс и находится в устойчивом состоянии.

Кроме лигнина в состав ЦО входят полисахариды - крахмал целлюлоза, гемицеллюлоза пектины, моносахариды (глюкоза, фрруктоза) минеральные и органические кислоты, смолы, вода, зольные элементы. Количественный состав этих органических и минеральных веществ (зола) представлен в таблице 4.1. Содержание воды и растворенных в ней минеральных солей микро и макроэлементов (зола) составляет 5..10\%, быстро разлагаемых высокомолекулярных органических соединений белков $-0,5 \ldots 10 \%$, липидов $2 . .20 \%$, алкалоидов, витаминов, гормонов, органические кислоты меньше $1 \%$ $[69$, c. 421$]$. 
Таблица 4.1

\section{Качественный и количественный состав биомассы}

(\% на сухую беззольную массу)

\begin{tabular}{|l|c|c|c|c|c|c|}
\hline \multirow{2}{*}{ Растения } & \multicolumn{2}{|c|}{ Углеводы } & \multirow{2}{*}{ Лигнин } \\
\cline { 2 - 6 } & $\begin{array}{c}\text { Гемицел- } \\
\text { люлозы, } \\
\text { пектин-- } \\
\text { вые в-ва }\end{array}$ & $\begin{array}{c}\text { Целю- } \\
\text { лоза } \\
\text { родст- } \\
\text { венные } \\
\text { им } \\
\text { в-ва }\end{array}$ & $\begin{array}{c}\text { Липиды, } \\
\text { дубиль- } \\
\text { ные } \\
\text { в-ва }\end{array}$ & \\
\hline $\begin{array}{l}\text { Хвойные: } \\
\text { Древесина } \\
\text { Хвоя }\end{array}$ & $15 \ldots 25$ & $45 \ldots 50$ & $25 \ldots 30$ & $0,5 \ldots 1,0$ & $2 \ldots 12$ & $0,1 \ldots 1,0$ \\
\hline $\begin{array}{l}\text { Лиственные: } \\
\text { Древесина } \\
\text { Листья }\end{array}$ & $15 \ldots 20$ & $15 \ldots 20$ & $20 \ldots 30$ & $3,0 \ldots 8,0$ & $5 \ldots 20$ & $2,0 \ldots 5,0$ \\
\hline $\begin{array}{l}\text { Многолетние } \\
\text { травы: } \\
\text { Злаки }\end{array}$ & $10 \ldots 20$ & $15 \ldots 25$ & $20 \ldots 30$ & $4,0 \ldots 10$ & $5 \ldots 15$ & $3,0 \ldots 8,0$ \\
Бобовые & $25 \ldots 35$ & $25 \ldots 40$ & $15 \ldots 20$ & $5,0 \ldots 12$ & $2 \ldots 10$ & $5,0 \ldots 10$ \\
\hline
\end{tabular}

Природный лигнин связан с целлюлозой и гемицеллюлозой в единый устойчивый лигноцеллюлозный комплекс, большая часть которого приходится на целлюлозу (рис. 4.5).

При изучении продуктов деструкции целлюлозосодержащей древесной биомассы при кислотном и щелочном гидролизе был определен элементарный состав технического лигнина и предложена модель строения технического лигнина [68, с. 706]. Гидролизный лигнин представляет собой полидисперсную суспензию темно-коричневого цвета (влажностью $65 \ldots 70$ \%) или твердый материал (влажностью 15\%), обладающий развитой системой микро- и макропор приближающейся к пористости древесного угля, химически стоек, имеет постоянный функциональный состав. В состав гидролизного лигнина кроме макромолекул лигнина (40...88\%) входят полисахариды (13...45\%), моносахариды минеральные и органические кислоты, смолы (5...19\%), гуминовые вещества, вода, зольные элементы. (5..10\%). При температуре 
$190^{\circ} \mathrm{C}$ происходит его разложение с образованием токсичных летучих веществ. В состав золы лигнина входят окислы: $\mathrm{Al}_{2} \mathrm{O}_{3}-1 \% ; \mathrm{SiO}_{2}-93,4 \% ; \mathrm{P}_{2} \mathrm{O}_{5}-1,5 \%$; $\mathrm{CaO}-1,5 \% ; \mathrm{Na}_{2} \mathrm{O}-0,3 \% ; \mathrm{K}_{2} \mathrm{O}-0,3 \% ; \mathrm{MgO}-0,3 \% ; \mathrm{TiO}_{2}-0,1 \%$.

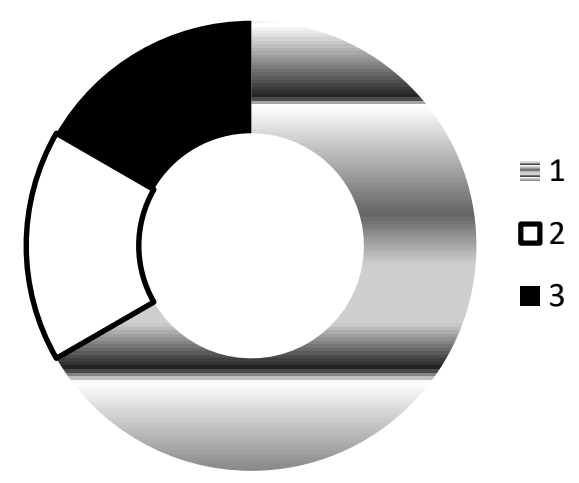

Рис. 4.5. Состав растительной ткани древесины: 1 - целлюлоза, 2 - гемицеллюлоза, 3 - лигнин

Обобщенный элементарный состав гидролизного лигнина (рис. 4.6). Макромолекула лигнина состоит из атомов углерода (65\%), кислорода (35\%) и водорода (10\%) имеет в структуре ароматические ядра, содержащие фенольные гидроксильные группы. Лигнин, полученный различными методами, отличается строением макромолекул лигнина, положением и содержанием свободных функциональных групп (-ОН и $\left.-\mathrm{OCH}_{3}\right)$. [68, 70].

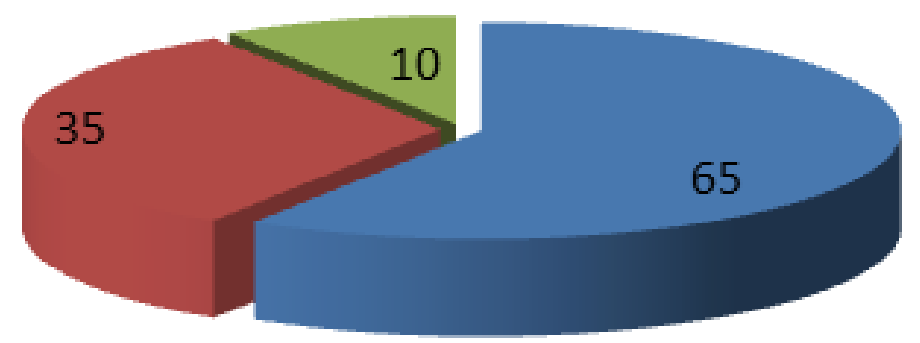

Углерод Кислород Водород

Рис. 4.6. Элементарный состав природного и технического лигнина 
Согласно модели Фрейденберга структурным звеном линейных макромолекул природного и гидролизного лигнина являются фенилпропановые ядра (рис.4.7), главным образом кониферилового спирта, которые соединяются между собой посредством эфирной или углеродной связи с образованием фуранового кольца.

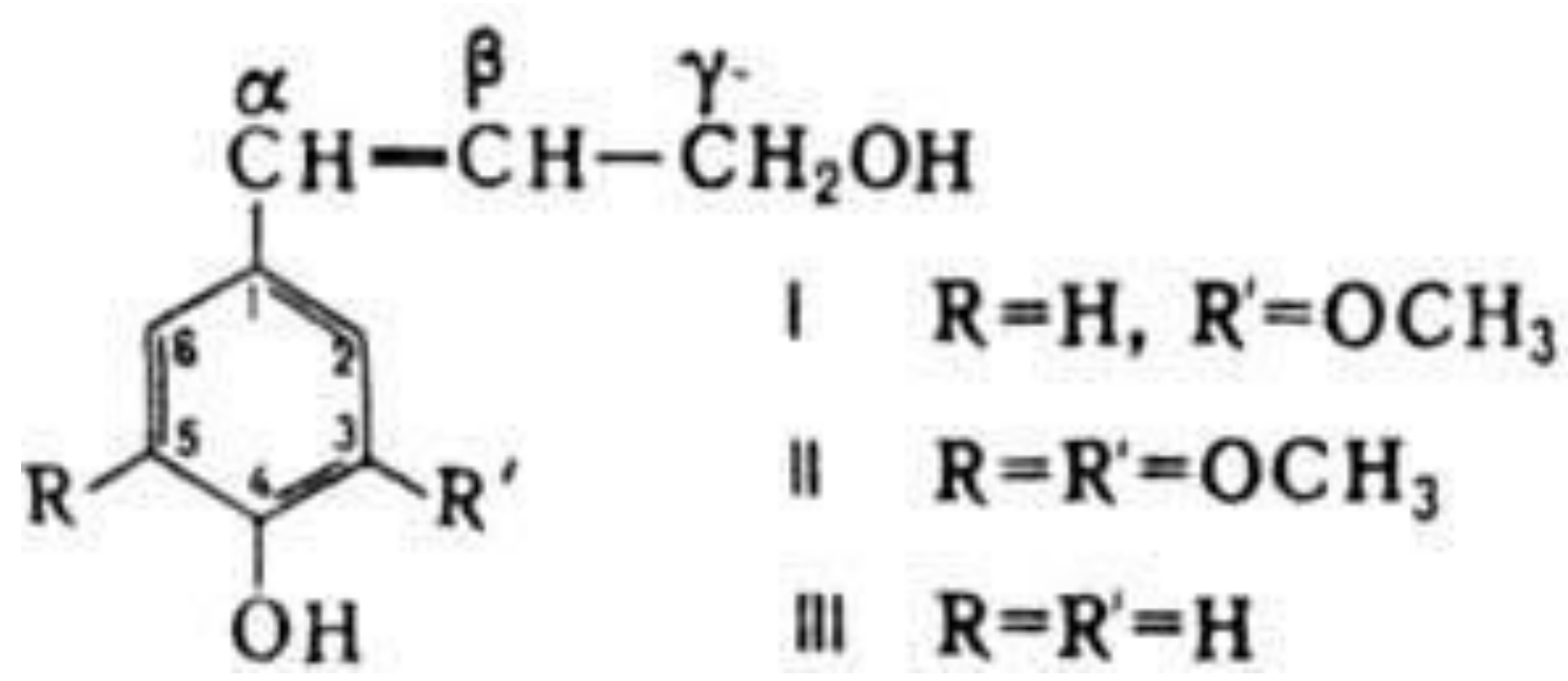

Рис. 4.7. Модель (Фрейденберга) строения макромолекул лигнина:

I - 3-метоксигидроксикоричного (кониферилового); II - 3,5-диметокси-4-гидроксикоричного (синапового); III - n-гидроксикоричного (n-кумарового) спиртов

Так, например, в состав гидролизного лигнина хвойных пород древесины входит конифериловый спирт, лиственных пород - конифериловый и синаповый спирты, травянистых растений и некоторых древесных пород (осины) входят и молекулы n-кумарового (III) спирта. Содержание метоксильных групп: $(20,5 \ldots 21,5 \%$, ) в хвойных $(15 \ldots 16 \%$, ) а в злаковых растениях $(14 \ldots 15 \%)$. 


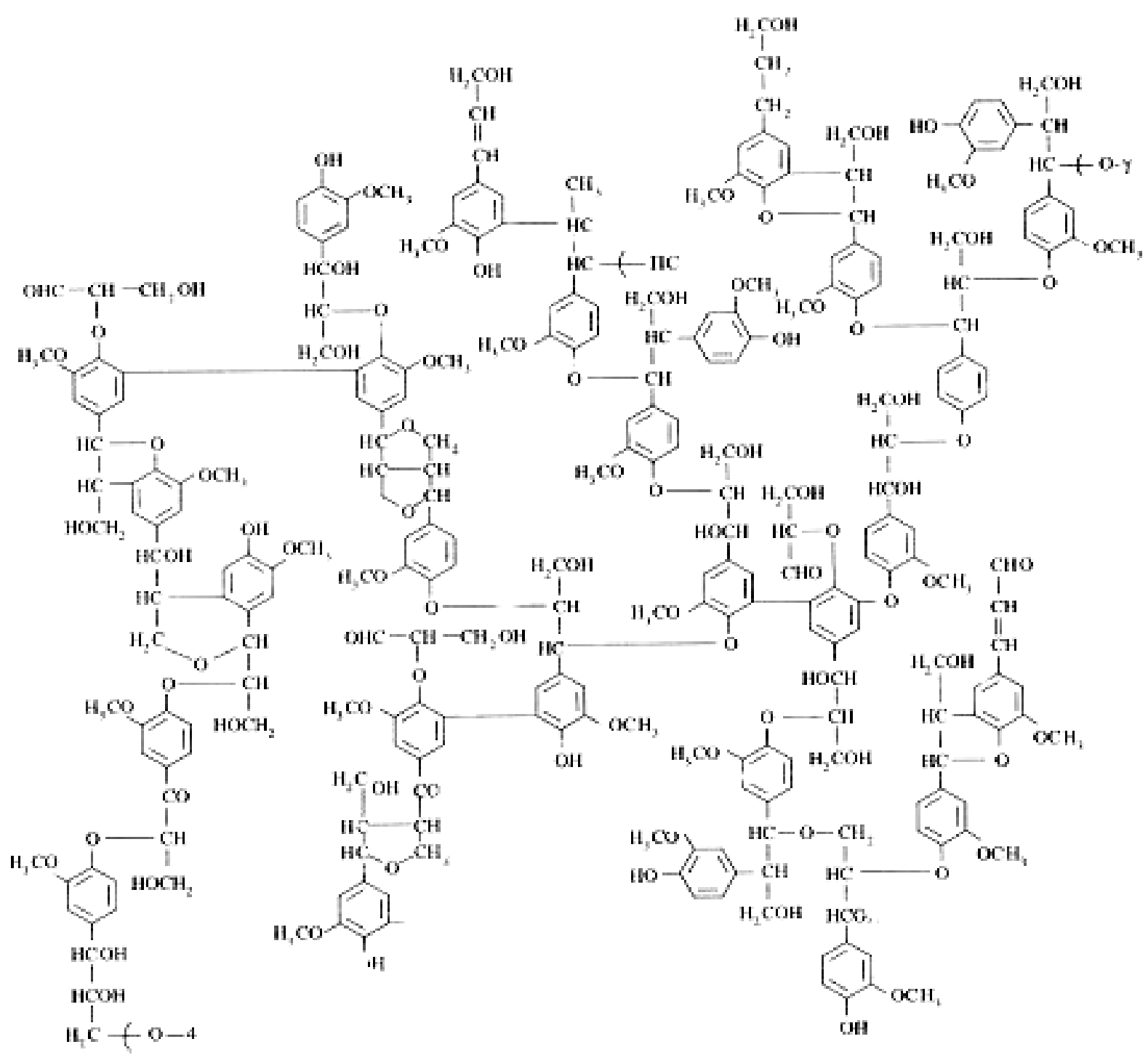

Рис. 4.8. Модель Класона строения макромолекул лигнина

В обобщенной модели Класона, полученного кислотным гидролизом, (рис.4.8) структурное звено макромолекулы лигнина представляет собой молекулы фенола, в которых часть атомов водорода в ароматических ядрах фенола замещена метоксильными группами $\left(-\mathrm{OCH}_{3}\right)$, а часть молекулами кониферилового спирта, при взаимодействии которых образуется сетчатая структура [70, с. 209].

Модифицированные лигнины способствуют стабилизации эксплуатационных показателей качества (светостойкость или термостойкость) композиционных материалов на их основе и могут быть использованы как 


\section{СТАБИЛИЗАЦИЯ СВОЙСТВ ТОПЛИВНО-ЭНЕРГЕТИЧЕСКИХ СИСТЕМ НА ОСНОВЕ ПРИРОДНЫХ И СИНТЕТИЧЕСКИХ ПОЛИМЕРОВ}

потенциальное возобновляемое сырье в различных сферах деятельности. Например, как наполнитель в производстве полимерных материалов (фенолоформальдегидных смол), компонент клеящих композиций в производстве картона и фанеры, для получения низких глинистых растворов, синтетических дубящих веществ, ванилина, пластификаторов в производстве цемента и кирпича, литейных крепителей. При смешении технического лигнина с нефтяными отходами получают топливо, которое используют для коммунально-бытовых нужд или в качестве восстановителя в черной и цветной металлургии [72].

\subsection{3 Современные инструментарии деструкции полимерных отходов}

Одной из основных задач при выборе инструментариев деструкции полимерных отходов является выбор и оптимизация технологических параметров деструкции с учетом показателей качества и безопасности полезных целевых продуктов. В зависимости от фактора воздействия на полимерные отходы: температуры, кислорода, света, механических нагрузок, радиации различают механические, термические, химические или биологические инструментарии деструкции полимеров (рис.4.9). Механическая деструкция полимерных отходов возможна при создании механических напряжений превышающих энергию связей атомов в структуре полимера.

Механические инструментарии деструкции ПЭТФ отходов основаны на сохранении прочностных и оптических характеристик материала, с получением промежуточных технологических масс с достаточным насыпным весом. Недостатком этого способа являются энергетические затраты на сбор, идентификацию, сортировку, измельчение отходов (рис. 4.10).

Измельчение протекает через ряд последовательных стадий, на которые затрачивается около 7..10\% производимой в мире электроэнергии. При измельчении под действием внешних сил затрачивается работа по разрушению 


\section{СТАБИЛИЗАЦИЯ СВОЙСТВ ТОПЛИВНО-ЭНЕРГЕТИЧЕСКИХ СИСТЕМ НА ОСНОВЕ ПРИРОДНЫХ И СИНТЕТИЧЕСКИХ ПОЛИМЕРОВ}

внутри- и межмолекулярных связей, образуются частицы заданной формы и размера без изменения химического состава и основных физико-механических свойств.

При измельчении уменьшается расстояние между частицами дисперсной фазы, увеличивается общая поверхность соприкосновения, улучшается однородность (оптимальный размер частиц) сырья ускоряется теплообмен между частицами технологических масс, улучшаются условия прессования, гранулирования, перемешивания, экстракции, экструзии, перекачивания по трубопроводам. Чрезмерное измельчение приводит к возрастанию сил притяжения и агрегации (слипанию) частиц.

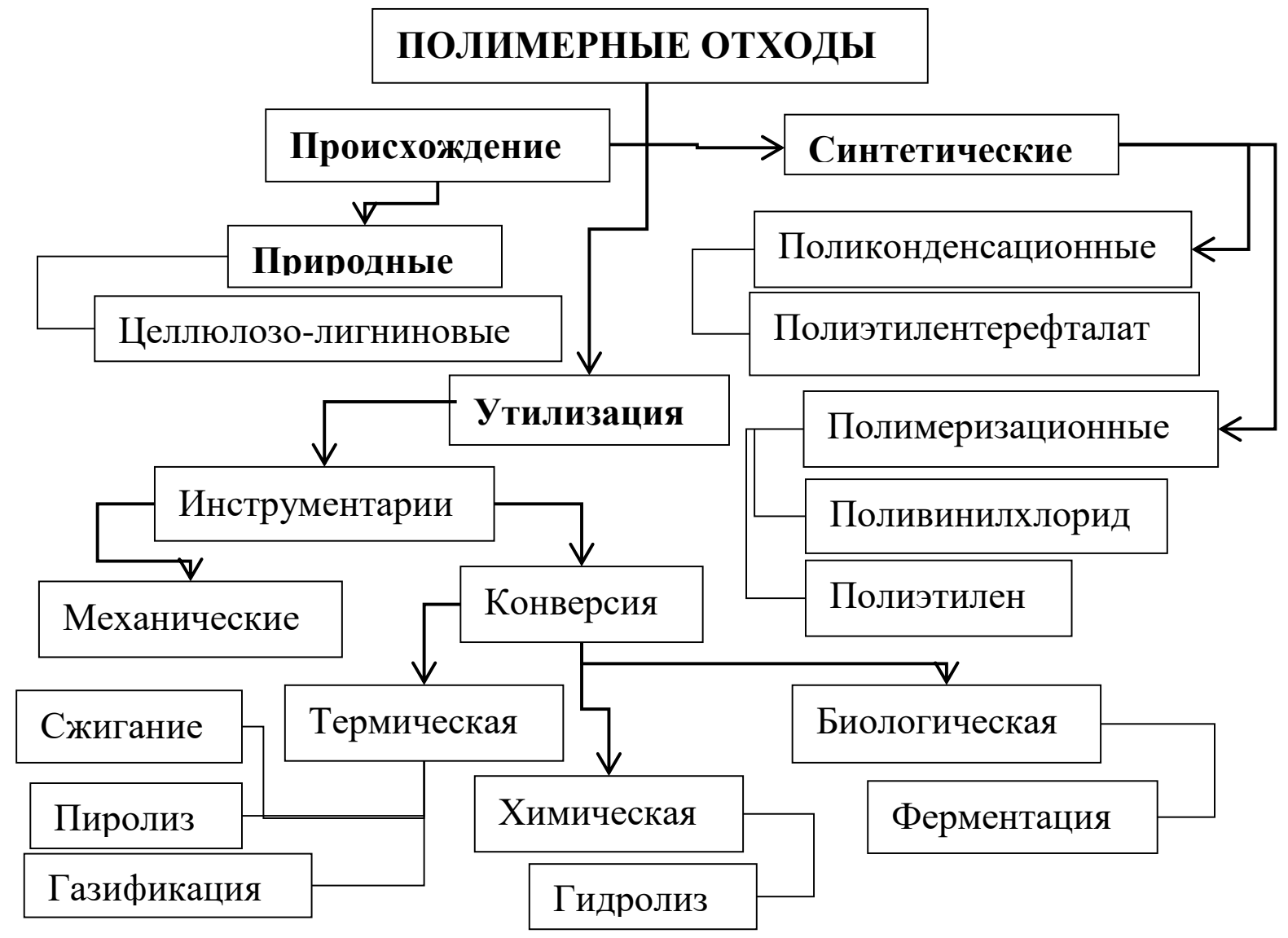

Рис. 4.9. Идентификации полимерных отходов и инструментариев утилизации 


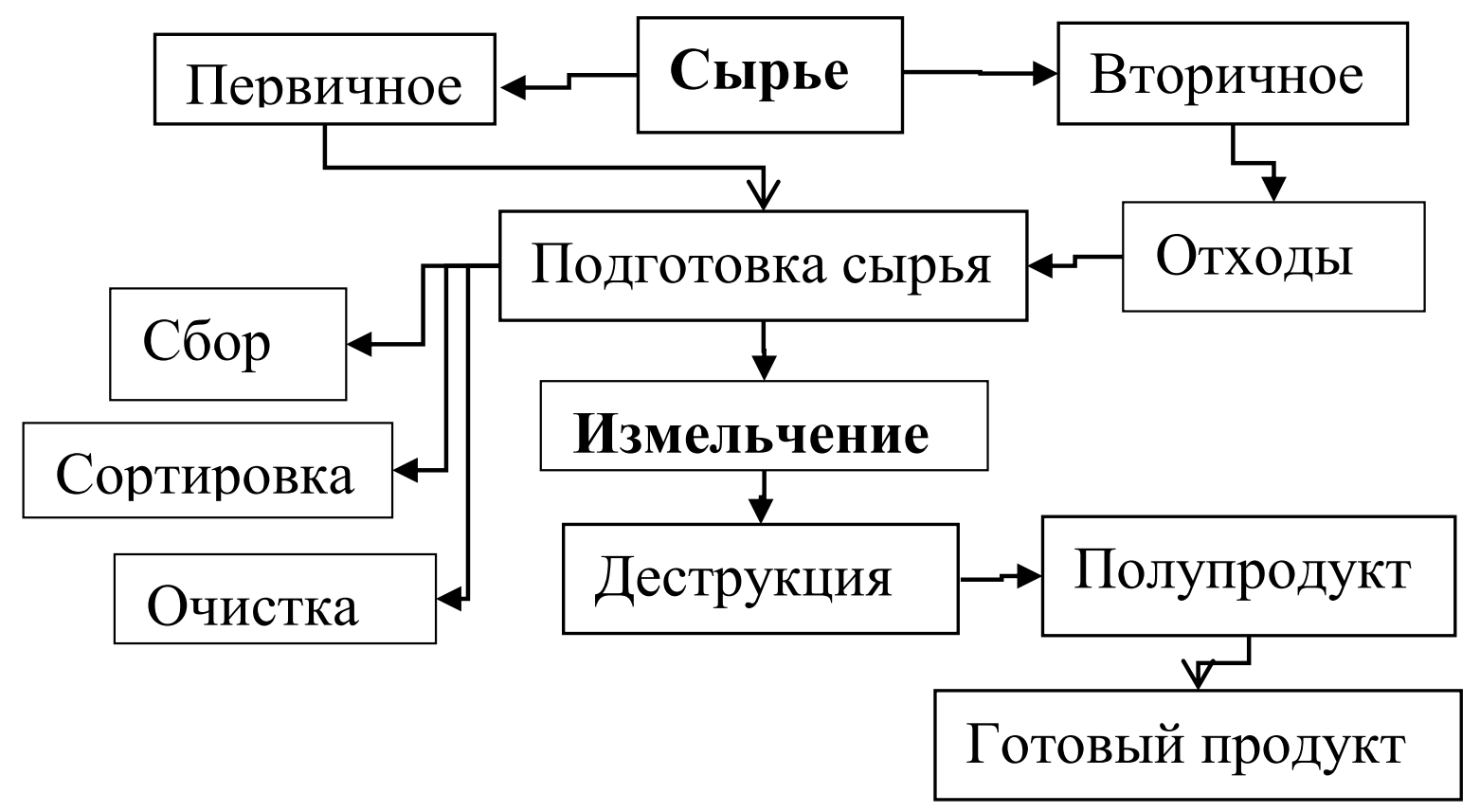

Рис. 4.10. Основные стадии технологии механической деструкции

Для устранения повторного измельчения, минимизации энергетических затрат процесс измельчения проводят ступенчато, с удалением на каждой стадии фракций одинакового размера. Грубое измельчение сырья основано на действии механических сил при раскалывании, раздавливании или ударе, а также сочетание этих сил при разламывании и истирании.

При тонком измельчении действуют вращательные, центробежные силы, эффекты кавитации ударных волн, а также движение с высокой скоростью навстречу друг другу частиц. Механические инструментарии ПЭТФ отходов позволяет получать промежуточные технологические массы - флексы (рис. 4.11).

В дальнейшем из них изготавливают широкий ассортимент изделий для бытовых и промышленных нужд: волокнистых наполнителей или нетканого полотна, пленок и листов, упаковочных материалов пищевых продуктов или напитков, строительные панели, декоративные материалы и другие (рис. 4.12). Кроме механических методов деструкции ПЭТФ отходов, широко используют термические инструментарии: сжигание, газификация, пиролиз для получения возобновляемых энергетических ресурсов. 


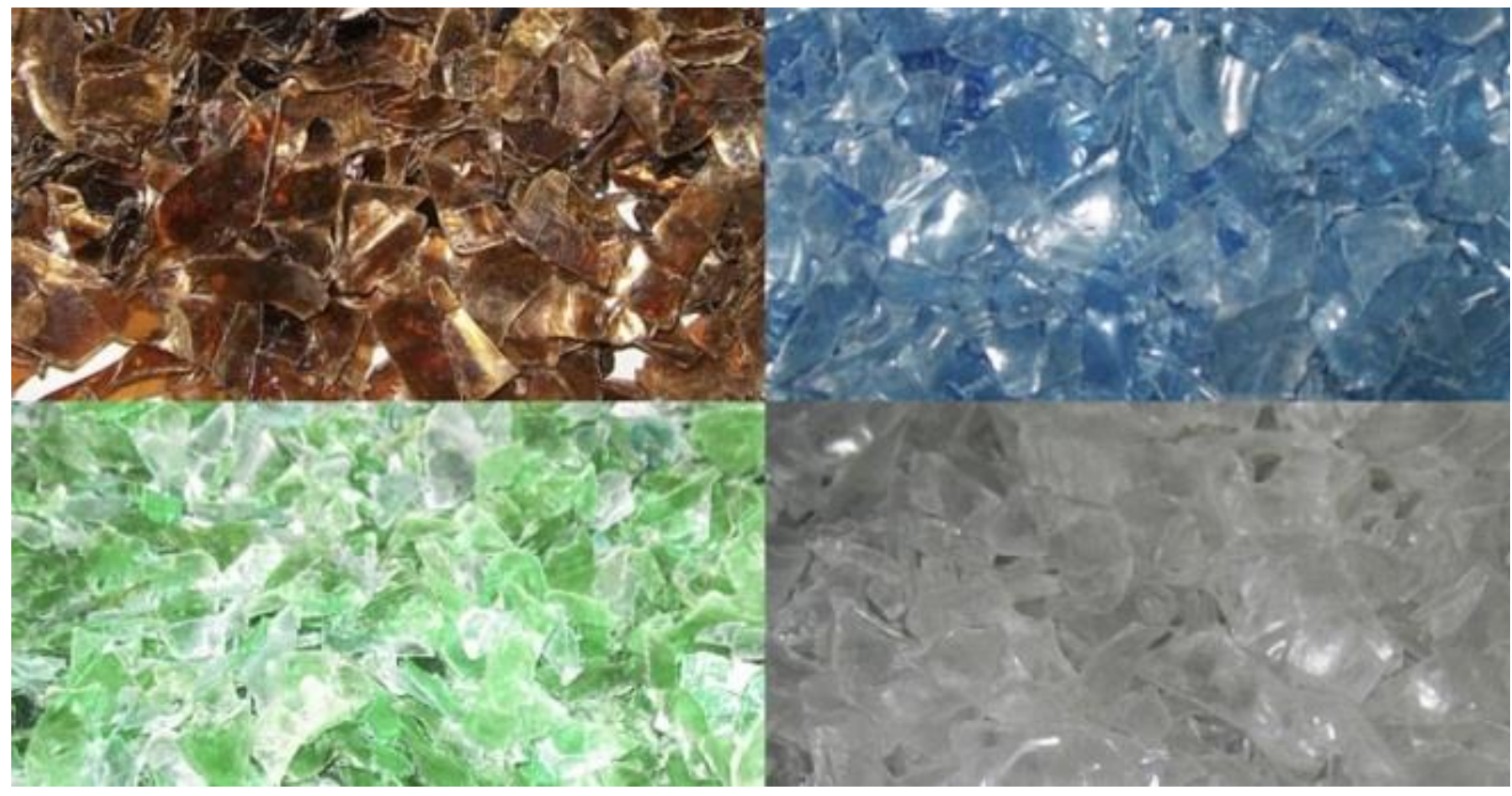

Рис. 4.11. Внешний вид ПЭТФ - флексов

Прямое сжигание термостойких синтетических полимерных отходов протекает через стадию плавления, и образования токсичных газов (хлорида водорода, оксидов азота, аммиака, цианистых соединений), что требует дополнительных затрат на поддержание высоких температур и очистку выбросов. Сжигание полимерных отходов в энергетических установках ( $\approx 40 \%)$ осуществляется через стадию плавления (начало термической деструкции) с получением тепловой (или электрической) энергии.

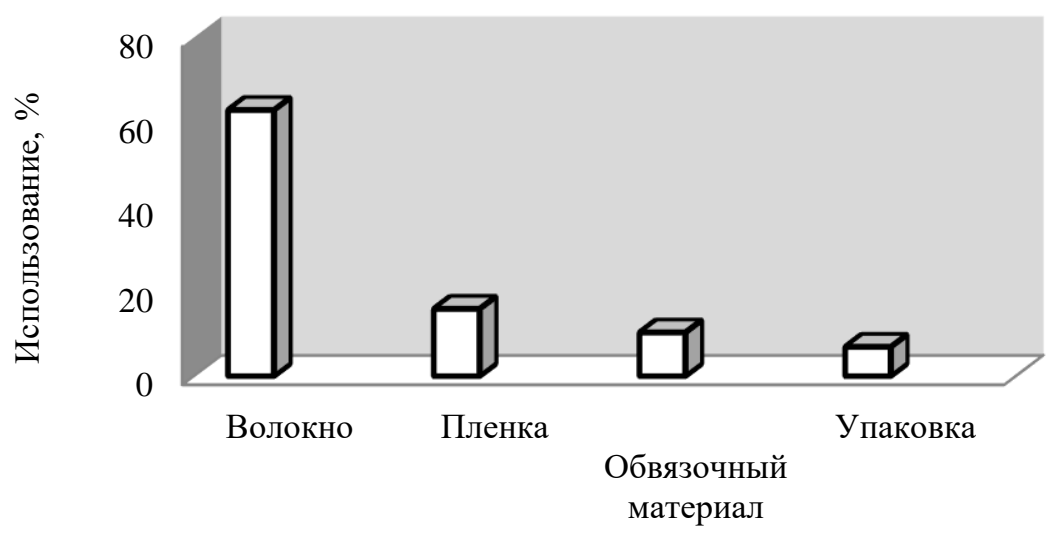

Вид полезного продукта

Рис. 4.12. Ассортимент полезных продуктов на основе отходов ПЭТФ 143 


\section{СТАБИЛИЗАЦИЯ СВОЙСТВ ТОПЛИВНО-ЭНЕРГЕТИЧЕСКИХ СИСТЕМ НА ОСНОВЕ ПРИРОДНЫХ И СИНТЕТИЧЕСКИХ ПОЛИМЕРОВ}

При этом происходит разрыв слабых (эфирных) связей с образованием свободных радикалов, понижение средней молекулярной массы и изменение структуры полимера. Незначительное изменение расположения атомов в основной цепи или боковых группах макромолекулы может оказать решающее влияние на механизм деструкции [73, 74]. При совместном действии повышенной температуры и кислорода образуются свободные радикалы, вследствие чего деструкция протекает по цепному механизму с образованием низкомолекулярных кислородосодержащих веществ: воды, углекислого газа, кетонов, альдегидов, спиртов, кислот. Преимущество данного инструментария заключается в высокой теплотворной способности $(\approx 20000$ кДж/кг) полимерных отходов и сокращения времени технологического процесса (отсутствии стадии сортировки). Теплотворная способность двух тонн отходов из пластиковых упаковок эквивалентна теплотворной способности 1 т нефти $[63,64]$. К недостаткам инструментариев прямого сжигания следует отнести накопление значительных объемов конечных продуктов золы, содержащей токсичные тяжелые металлы и летучих газообразных веществ (бенз- $\alpha$-пирена) и хлорсодержащих (диоксинов), что требует дополнительных затрат на их очистку.

Использование инструментариев пиролиза позволяет получать широкий ассортимент полезных продуктов, которые можно использовать как потенциальные возобновляемые энергетические ресурсы. При деструкции полимерных отходов в условиях высокой температуры $\left(600 \ldots 800^{\circ} \mathrm{C}\right)$ в вакууме без доступа кислорода получают преимущественно газообразные вещества: пропилен, этилен, водород жидкие и твердые остатки (рис. 4.13). Газ используется как топливо, жидкие в качестве теплоносителя, твердые (кокс и смолы) - как сырье в промышленных целях. Если полимерные отходы содержат серу, то в составе газа, кроме $\mathrm{H}_{2}$ : $\mathrm{CO}$ присутствуют токсичные газы сероводород $\left(\mathrm{H}_{2} \mathrm{~S}\right)$ и меркаптаны $(\mathrm{RCH})$, которые требуют очистки. В условиях низкотемпературного пиролиза $\left(400 \ldots 450^{\circ} \mathrm{C}\right)$ синтетических полимерных 
отходов продукты деструкции состоят на 95\% из жидких углеводородов и на 5\% - из горючего газа. В зависимости от химического состава синтетических полимерных отходов жидкая фракция низкотемпературного пиролиза может представлять собой топливные материалы: бензин, лигроин, керосин, гайзоль, тяжелые масла. Остаток пиролиза (гудрон или карбонизат) используют для получения пористых углеродных сорбентов или активированных углей (АУ) [75].

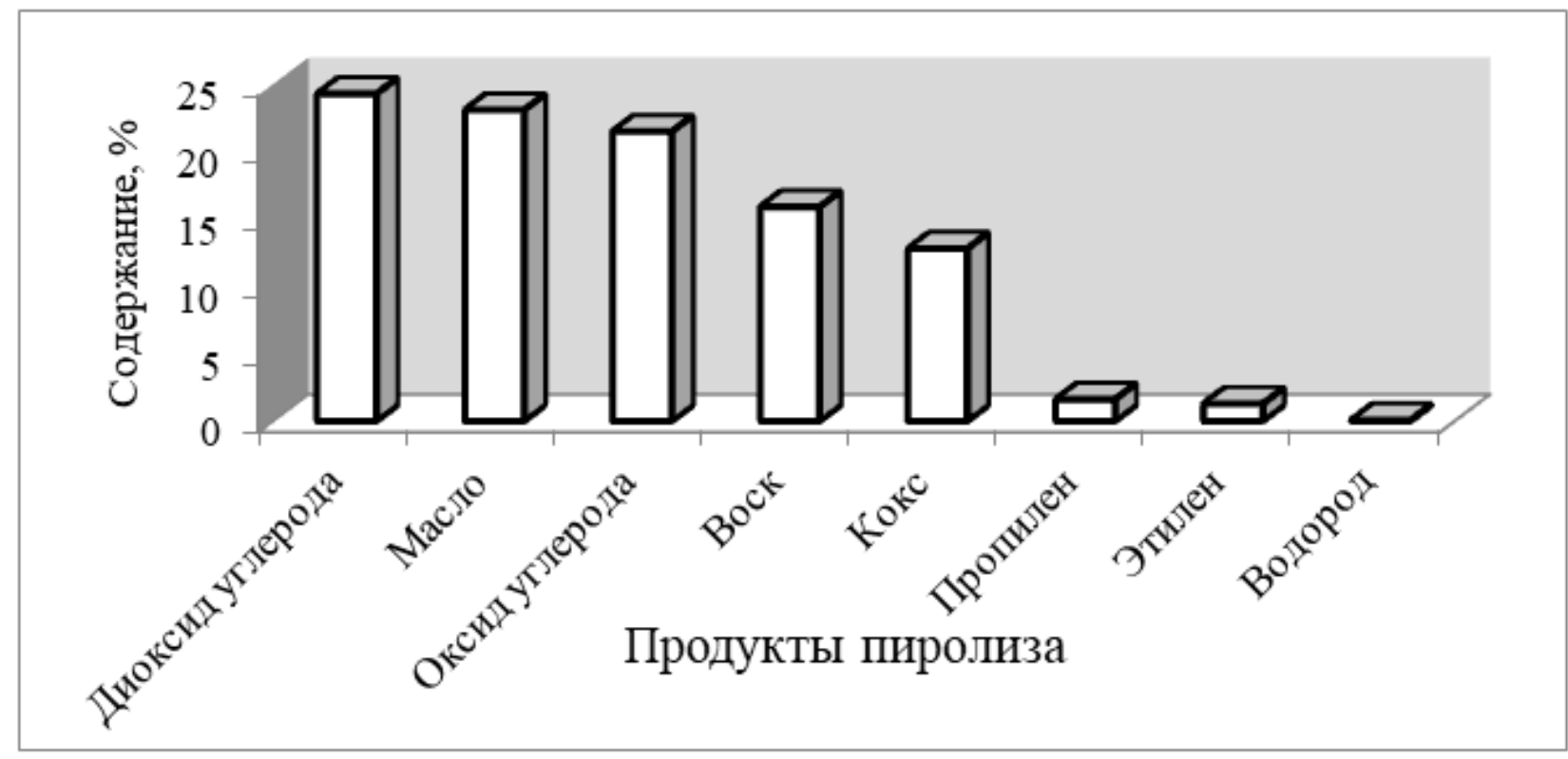

\section{Рис. 4.13. Продукты пиролиза ПЭТФ}

Жидкая фракция обладает высокой теплотворной способностью (35000...40000 кДж / кг) и после дополнительной обработки может быть использована в качестве жидкого топлива подобного мазуту. При низкотемпературном пиролизе $\left(\mathrm{t}<600^{\circ} \mathrm{C}\right)$ отходов из полиэтилентерефталата (ПЭТФ) образуются низкомолекулярные мономеры (диметилтерефталат и этиленгликоль), которые возвращаются в технологический цикл для синтеза полимера заданной молекулярной массы и структуры [65]. 


\section{СТАБИЛИЗАЦИЯ СВОЙСТВ ТОПЛИВНО-ЭНЕРГЕТИЧЕСКИХ СИСТЕМ НА ОСНОВЕ ПРИРОДНЫХ И СИНТЕТИЧЕСКИХ ПОЛИМЕРОВ}

Газификация твердых полимерных отходов высокотемпературный $\left(600 \ldots 1100^{\circ} \mathrm{C}\right)$ физико-химический процесс превращениях углерода полимера в горючий газ $\left(\mathrm{H}_{2}, \mathrm{CO}, \mathrm{CH}_{4}\right)$ [76] или жидкие углеводороды (метанол, этанол, бутанол) с помощью кислорода или других окислителей для производства тепловой энергии (4,6-6,3 мДж) в районах, удаленных от электрических и газовых сетей [76, 77 - 79]. Газификация позволяет минимизировать в выбросах содержание токсичных газов оксидов азота и серы. Состав продуктов газификации зависит от состава отходов, времени пребывания отходов в реакторе и скорости нагрева. При медленном нагревании сырья образуются газообразные продукты, при быстром нагревании - жидкие продукты (спирты, масла). В твердой фазе остаются неорганические компоненты и продукты химической модификации (углеподобный остаток). Соотношение газообразных составляющих газа может изменяться в зависимости от вида полимерных отходов и условий проведения газификации. С повышением температуры увеличивается доля $\mathrm{CO}$, с возрастанием давления $-\mathrm{H}_{2}$ и $\mathrm{CH}_{4}$. Синтетический генераторный газ, полученный при газификации биополимерных отходов (древесных) не содержит вредных сернистых примесей и соединений (табл. 4.2).

Таблица 4.2

\section{Состав генераторного газа}

\begin{tabular}{|c|c|c|c|c|c|c|c|c|}
\hline Состав газа & $\mathrm{CO}$ & $\mathrm{H}_{2}$ & $\mathrm{CH}_{4}$ & $\mathrm{CmHn}$ & $\mathrm{H}_{2} \mathrm{~S}$ & $\mathrm{CO}_{2}$ & $\mathrm{O}_{2}$ & $\mathrm{~N}_{2}$ \\
\hline Содержание, \% & 17.2 & 4.05 & 6.82 & 1.24 & - & 15.1 & 0.8 & 54.7 \\
\hline
\end{tabular}

Содержание смол в генераторном газе менее $50 \mathrm{Mr} / \mathrm{Hм}^{3}$, что соответствует международным нормам, предъявляемым к топливу для двигателей внутреннего сгорания. Газификация целлюлозосодержащих отходов в присутствии кислорода $\left(\mathrm{O}_{2}\right)$ воздуха протекает с разложением целлюлозы $\left(\mathrm{C}_{6}\left(\mathrm{H}_{2} \mathrm{O}\right)_{6}\right)$ и образованием генераторного газа, который очищается до синтезгаза по обобщенному уравнению 4.1 


$$
\mathrm{C}_{6}\left(\mathrm{H}_{2} \mathrm{O}\right)_{6}+1,5 \mathrm{O}_{2} \rightarrow 6 \mathrm{CO}+3 \mathrm{H}_{2}+3 \mathrm{H}_{2} \mathrm{O} .
$$

Однако, в связи с неопределенным составом целлюлозосодержащих отходов, условий газификации биополимеров, механизм деструкции сложный и протекает через ряд промежуточных стадий (4.2...4.9)

$$
\begin{array}{lc}
\mathrm{C}+0,5 \mathrm{O}_{2} \rightarrow \mathrm{CO}_{2} & -109 \text { кДж/моль } \\
\mathrm{C}+\mathrm{CO}_{2} \rightarrow 2 \mathrm{CO} & +172,5 \text { кДж/моль } \\
\mathrm{C}+\mathrm{H}_{2} \mathrm{O} \rightarrow \mathrm{CO}+\mathrm{H}_{2} & +131,2 \text { кДж/моль } \\
\mathrm{C}+\mathrm{O}_{2} \rightarrow 2 \mathrm{CO}_{2} & -284,3 \text { кДж/моль } \\
\mathrm{CO}+\mathrm{H}_{2} \mathrm{O} \leftrightarrow \mathrm{CO}_{2}+\mathrm{H}_{2} & \pm 131,4 \text { кДж/моль } \\
\mathrm{C}+2 \mathrm{H}_{2} \rightarrow \mathrm{CH}_{4} & +74,8 \text { кДж/моль } \\
\mathrm{CO}+3 \mathrm{H}_{2} \rightarrow \mathrm{CH}_{4}+\mathrm{H}_{2} \mathrm{O} & -206,2 \text { кДж/моль } \\
\mathrm{CO}+\mathrm{H}_{2} \rightarrow 0,5 \mathrm{CH}_{4}+0,5 \mathrm{CO}_{2} & -123,8 \text { кДж/моль }
\end{array}
$$

Суммарная скорость газификации будет определяться лимитирующей стадией. Для снижения температуры деструкции лигнина и целлюлозы и ускорения процесса газификации используют эффективные катализаторы. В присутствии катализаторов получают жидкие (бензин, керосин, газойль) или твердые смеси углеводородов, близкие по химическому составу к продуктам фракционирования нефти. Недостатком каталитических методов является низкая стабильность и селективность катализаторов. На долю каталитических технологий в мировой экономике приходится 35\%. Общим недостатком инструментариев газификации являются высокие температуры деструкции, низким содержанием $(\approx 30 \%)$ синтез газа. В зависимости от природы катализатора и условий газификации ЦО можно усовершенствовать качество топливного материала, преобразованием синтез газа в моторное топливо (синтетический бензин), и повысить производительность газогенератора.

Химические инструментарии деструкции полимеров основаны на использовании химических реагентов концентрированных кислот, щелочей (гидролиз), спиртов (гликолиз), аминов (аминолиз) и протекают при высоких температурах, давлении и используют в рециклинге синтеза полимеров. Для 


\section{СТАБИЛИЗАЦИЯ СВОЙСТВ ТОПЛИВНО-ЭНЕРГЕТИЧЕСКИХ СИСТЕМ НА ОСНОВЕ ПРИРОДНЫХ И СИНТЕТИЧЕСКИХ ПОЛИМЕРОВ}

ускорения процесса деструкции используют катализаторы, ультразвук. При гидролизе отходов ПЭТФ при температурах превышающих $200^{\circ} \mathrm{C}$ образуются продукты деструкции: оксид углерода $(\mathrm{CO})$ и формальдегид, диметиловый эфир фталевой кислоты, диметилфталат, ацетальдегид, которые после очистки возвращаются в технологический процесс. При метанолизе деструкция отходов ПЭТФ протекает при воздействии метанола и температуры выше $150^{\circ} \mathrm{C}$, давлении 1,5 МПа, катализатора.

Возможность применения химических инструментариев рассматривали на примере низкотемпературной деструкции полимерных бытовых отходов: бутылей из ПЭТФ для хранения пива марки «Афанасий» (темно-коричневого цвета) - ПЭТФ 2 и минеральной воды «Кашинская» (прозрачные) - ПЭТФ [80, с. 112]. Деструкцию ПЭТФ отходов осуществляли в диапазоне температур $280 \ldots 400^{\circ} \mathrm{C}$ в присутствии кислорода воздуха при скорости нагрева десять градусов в минуту $\left(10^{\%}\right.$ мин) по изменению концентрации карбоксильных групп от времени и построения кинетических кривых. Анализ кинетических кривых показал, что в диапазоне температур $280^{\circ} \ldots 330^{\circ} \mathrm{C}$ не наблюдается значительного изменения кислотного числа $(\approx 4$ мг КОН/г) в течение 40 минут, то есть деструкция ПЭТФ 1 не происходит (рис. 4.14 а).
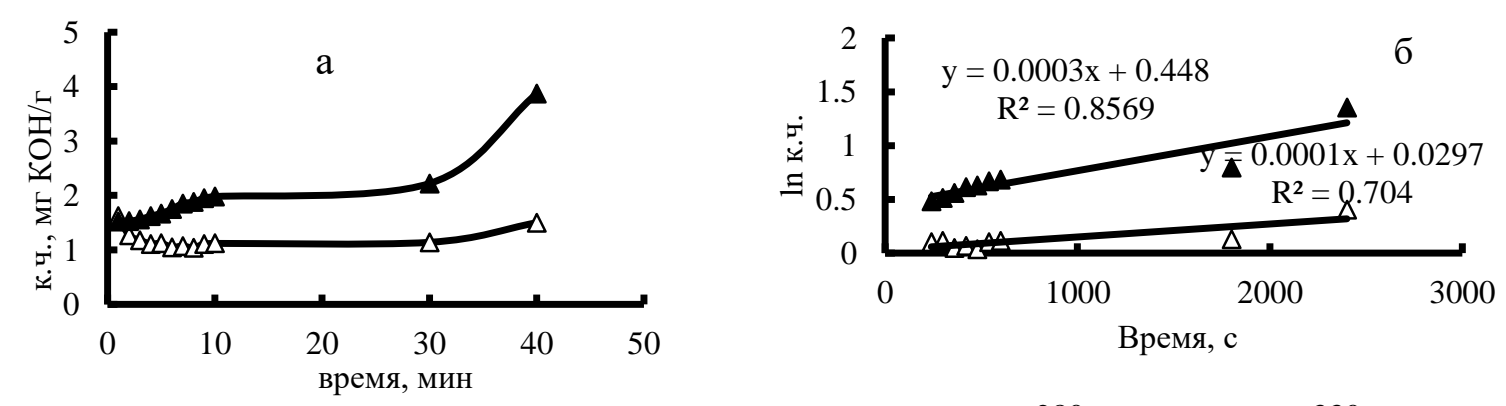

$\triangle 280 \quad \Delta 330$

Рис. 4.14. Изменение концентрации карбоксильных групп (а) и $\ln$ к.ч.

(б) ПЭТ $\Phi_{1}$ от времени при температурах $280^{\circ} \mathrm{C}(\Delta)$ и $330^{\circ} \mathrm{C}$ 


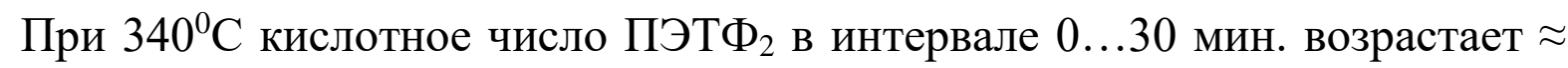
10 мг КОН/г (рис. 4.15 а), а при температуре $400^{\circ} \mathrm{C}$ в течение 30 минут кислотное число возросло в $30 \ldots 40$ раз. Математическая обработка кинетических кривых свидетельствует о первом порядке реакции (рис. 4.14 б, 4.15 б).

По полученным кинетическим параметрам был построен график в координатах Аррениуса $\ln \mathrm{k}$ - 1/T (рис.4.16) и по тангенсу наклона кривой рассчитана энергия активации процесса термической деструкции ПЭТФ 1 и ПЭТФ 2 . Кажущееся значение энергии активации термической деструкции отходов на основе ПЭТФ $($ (бутылки для хранения минеральной воды «Кашинская») составило - 140 кДж/моль, а отходов на основе ПЭТФ 2 (бутылки для хранения пива «Афанасий») - 187 кДж/моль.

Полученные закономерности можно объяснить исходя из основных положений теории случайных разрывов [74]. На начальном этапе при температурах близких температуре плавления полимера скорость реакции образования карбоксильных групп мала и соответствует индукционному периоду, на котором происходит разрыв физических связей между макромолекулами. При температуре $400^{\circ} \mathrm{C}$ происходит разрыв наиболее слабых связей в главной цепи (-C-O-) с образованием свободных радикалов и ускорения реакции деполимеризации по цепному механизму с образованием олигомеров через стадию активного промежуточного комплекса и образованием свободных карбоксильных групп.
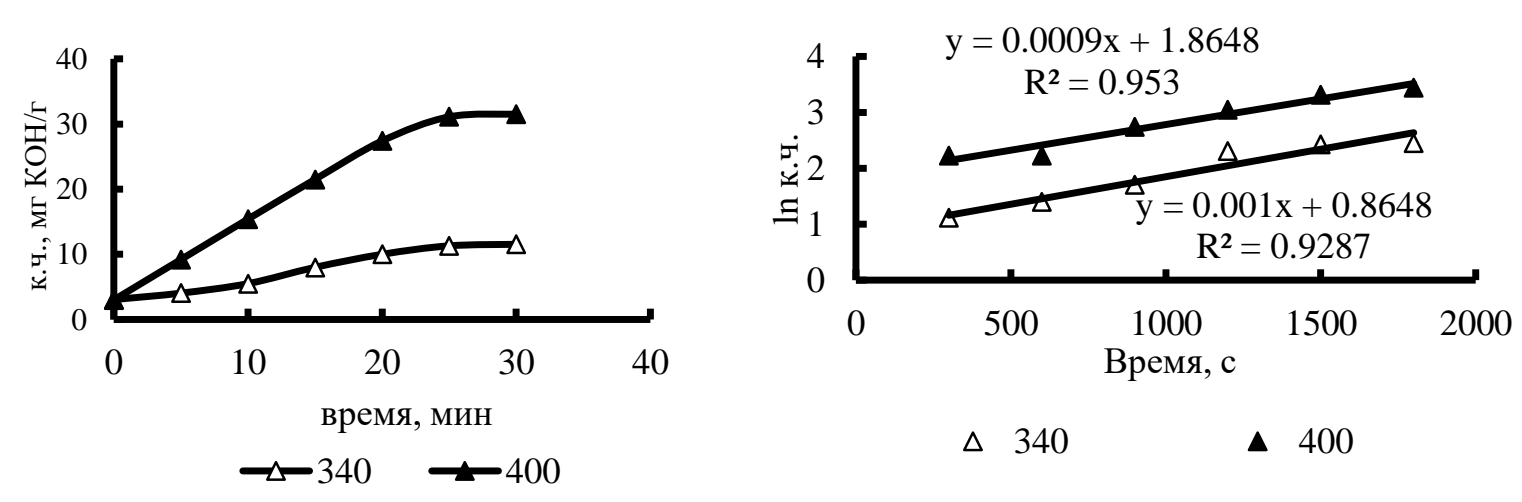

$\triangle 340 \quad \Delta 400$

Рис. 4.15. Изменение концентрации карбоксильных групп (а) и $\ln$ к.ч. (б)

ПЭТФ от $_{2}$ времени при температурах $340^{\circ} \mathrm{C}, 400^{\circ} \mathrm{C}$

149 


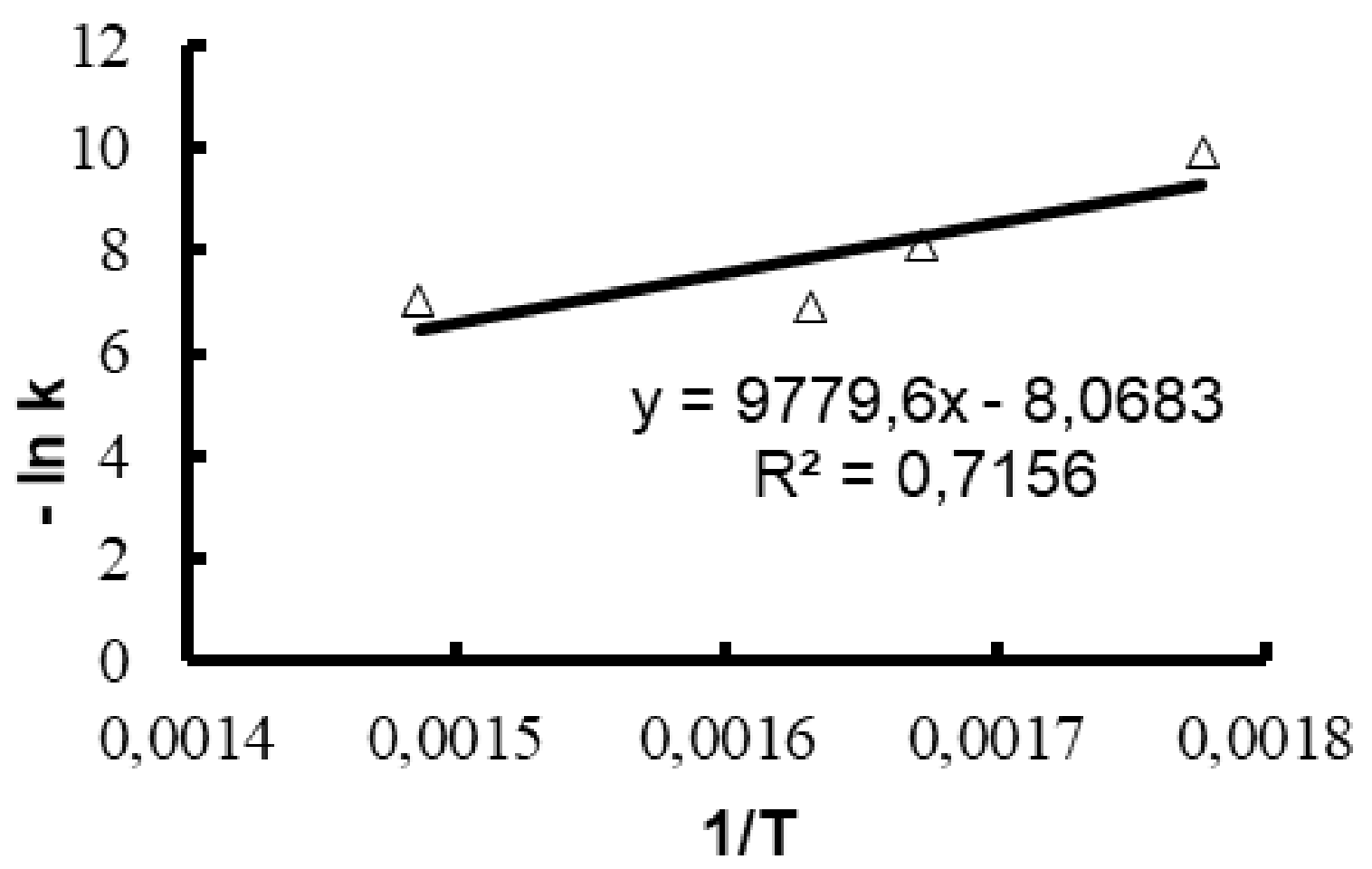

Рис. 4.16. Изменение $\ln \mathrm{k}$ от $1 / \mathrm{T}$ процесса термической деструкции ПЭТФ в интервале температур $280 . . .400^{\circ} \mathrm{C}$

Кинетические исследования низкотемпературной деструкции $\left(280 \ldots 400^{\circ} \mathrm{C}\right)$ обосновали гипотезу модификации битумных композиций [81]. Введение продукта деструкции ПЭТФ в битум позволило повысить эксплуатационные характеристики асфальтобетонных смесей: морозостойкость и сопротивление к механическим нагрузкам (деформации сдвига), адгезию к минеральным составляющим асфальтобетонных смесей и использовать как дорожно-строительные материалы. Повысить эксплуатационные характеристики битумных композиций можно при использовании в качестве функциональных модифицирующих добавок технического лигнина, который способствует ускорению протекания физико-химических реакций с сажей и битумами с образованием композиционных материалов [82]. Усовершенствование методологии технического регулирования стабильности качества полимерных отходов возможно с помощью инноваций, в частности, совместного использования технического лигнина и продуктов переработки 
ПЭТФ для модификации битумных композиций. Химическая природа лигнина, позволит стабилизировать продукты деструкции ПЭТФ и улучшить эффективность свето- и термостойкость изготовленных из этих отходов полезных продуктов [84].

Применение химических инструментариев деструкции природных полимеров древесины в промышленности основано на гидролизе. При воздействии кислот или щелочей, высоких температур и давлении происходит разрушение прочных связей между лигнином и целлюлозой в макромолекуле полимера, уменьшение молекулярной массы и переход их в свободное состояние. При этом повышается реакционная активность гидролизного (технического) лигнина за счет образования свободных функциональных групп (метоксильных, гидроксильных или карбонильных), способных участвовать в реакциях хлорирования, нитрования, окисления с образованием модифицированных лигнинов и увеличивается растворимость органических растворителях (этаноле диоксане, диметисульфоксиде, уксусной кислоте, феноле и других). Гемицеллюлоза подвергается кислотному гидролизу легче, чем целлюлоза. Недостатками химического способа конверсии ЦО являются высокая температура $\left(150 \ldots 180^{\circ} \mathrm{C}\right)$, избыточное давление $2,5 \ldots 3,0$ кгс/см ${ }^{2}$, и образование в качестве побочного химически активного продукта гидролизного лигнина [85, с. 41].

Биологические инструментарии утилизации находят все более широкое применение в России и за рубежом (Бразилии, Китае, Индии, Швеции, Германии, США, Канаде). Они основаны на способности различных штаммов микроорганизмов К биохимическому разложению (биоконверсии) биополимеров: углеводов (целлюлозы), белков, лигнина на простые составляющие (моносахариды, кислоты, биогаз). При использовании чистых культур грибов процесс биоконверсия происходит медленно. Поэтому используют эффективные системы штаммов микроорганизмов (Flavobacterium, Agrobacterium u Pseudomonas), способных разлагать лигнин до метана и наращивать биомассу. Однако эти штаммы чувствительны к действию сильных 
кислот, щелочей или высоких температур. На процесс биоконверсии влияет химический и гранулометрический состав биомассы, температура, влажность, кислород воздуха. Целлюлоза и гемицеллюлоза под действием ферментов микроорганизмов расщепляются до моносахаридов, согласно химической реакции

$$
\left(\mathrm{C}_{6} \mathrm{H}_{10} \mathrm{O}_{5}\right)_{\mathrm{x}}+\mathrm{n} \mathrm{H}_{2} \mathrm{O} \rightarrow \mathrm{C}_{6} \mathrm{H}_{12} \mathrm{O}_{6} .
$$

Разрушение лигнина с помощью бактерий происходит настолько медленно, что совершенно неэффективно для промышленности. При температуре больше $55^{0} \mathrm{C}$ грибы погибают [68, с. 723]. Ускоренное действие на деструкцию природного лигнина выявлено у представителей родов (Pholiota, Clitocybe, Lenzites, Panus Poria, Trametes и др.). Аэробная биоконверсия (компостирование) с помощью дождевых червей (Eisenia fjetida Lumbricus rubellus) протекает в течение $50 \ldots 200$ суток при температуре $16 \ldots 30^{\circ} \mathrm{C}$, влажности $60 \%$, аэрации и перемешивании. При этом одновременно происходит биосинтез гумуса.

Преимущество биологических инструментариев деструкции связаны с простотой генома, легкой его адаптации и лабильности в среде обитания, высокой скорости протекания ферментативных реакций при низких температурах $\left(20 \ldots 60^{\circ} \mathrm{C}\right)$ и наращивания клеточной массы. Недостатком этих инструментариев является многокомпонентность питательных сред; необходимость стерилизации питательных сред, оборудования и коммуникаций, низкая рентабельность ферментативного гидролиза, а также трудности в управлении процессом биосинтеза и автоматизации. При одинаковой степени деструкции $(25 \ldots 48 \%)$ целлюлозосодержащего сырья, производительность гидролизных аппаратов в $5 \ldots 10$ раз превосходит производительность ферментеров. Кроме того, необходимо учитывать индивидуальные особенности «поведенческих реакций» биообъектов в конкретных условиях культивирования, а именно: чувствительность к воздействию физико-механических факторов при перемешивании, специфику наследственных свойств данного вида, механизм обменных и биохимических 


\section{СТАБИЛИЗАЦИЯ СВОЙСТВ ТОПЛИВНО-ЭНЕРГЕТИЧЕСКИХ СИСТЕМ НА ОСНОВЕ ПРИРОДНЫХ И СИНТЕТИЧЕСКИХ ПОЛИМЕРОВ}

процессов. Способность микроорганизмов к мутации при изменении технологических параметров может привести к непредвиденному изменению биохимических реакций, и, соответственно химическую природу и свойства продуцируемого продукта.

Природные полимерные отходы содержат устойчивые к биологическому воздействию полимеры: лигнин, полисахариды - целлюлозу, крахмал и менее стойкие полимеры белки, липиды. Превращение целлюлозосодержащих отходов в сахаристые вещества происходит в два этапа: химического гидролиза с выделением модифицированного лигнина из продуктов гидролиза и ферментативного гидролиза целлюлозы в глюкозу. Избыточное содержание лигнина в продуктах гидролиза приводит к гибели микроорганизмов и снижении скорости гидролиза в 10 раз. Очищенный от лигнина субстрат целлюлозы подвергают ферментативному гидролизу растительного сырья с использованием штамма гриба Trichoderma viride с получением глюкозного концентрата с последующим биотехнологическим получением на его основе дрожжей и этанола и белкового корма для сельскохозяйственных животных $[84$, c. 90$]$.

В связи с тем, что макромолекулы полимеров крахмала и целлюлозы построены из остатков одного моносахарида - глюкозы и имеют молекулярную формулу $\left(\mathrm{C}_{6} \mathrm{H}_{10} \mathrm{O}_{5}\right)_{\mathrm{n}}$, то при ферментативном гидролизе (гликолизе) расщепляются бактериями до моносахаридов

$$
\underset{\substack{\text { Црахмал } \\ \text { Целлюлоза }}}{\left(\mathrm{C}_{6} \mathrm{H}_{10} \mathrm{O}_{5}\right.}+\mathrm{n} \mathrm{H}_{2} \mathrm{O} \stackrel{\alpha \text {-амилаза }}{\longrightarrow} \quad \mathrm{n}_{\text {Глюк } \mathrm{H}_{12} \mathrm{O}_{6}}
$$

которые в свою очередь, самопроизвольно окисляются до углекислого газа и воды. Свойства и скорость гидролиза этих полимеров зависят от положения свободной гидроксильной группы $(-\mathrm{OH})$ в звене мономера. Крахмал состоит из остатков $\alpha$-глюкозы, а целлюлоза - из $\beta$-глюкозы.

Скорость ферментативного гидролиза крахмала и гемицеллюлозы превышает скорость деструкции целлюлозы. При гидролизе гемицеллюлозы 


\section{СТАБИЛИЗАЦИЯ СВОЙСТВ ТОПЛИВНО-ЭНЕРГЕТИЧЕСКИХ СИСТЕМ НА ОСНОВЕ ПРИРОДНЫХ И СИНТЕТИЧЕСКИХ ПОЛИМЕРОВ}

кроме глюкозы образуются пентозы - ксилоза $\left(\mathrm{C}_{5} \mathrm{H}_{10} \mathrm{O}_{5}\right)$. Субстрат содержит смесь высших жирных кислот (около $76 \%$ ), ацетатов ( $\approx 20 \%$ ) и водорода (4 \%). Образовавшаяся глюкоза растворяется в воде и становится доступной формой питания для микроорганизмов и способствует росту их клеток и наращиванию биомассы. Освобождающуюся энергию микроорганизмы используют в качестве тепла [86]. При использовании систему анаэробных и аэробных штаммов микроорганизмов в различных условиях их культивирования при биоконверсии целлюлозосодержащих отходов можно получить различные полезные продукты (рис. 4.17). В этом случае механизм биоконверсии будет протекать в несколько анаэробных и аэробных стадий. На первой стадии в анаэробных условиях образуются пировиноградная кислота (пируват) $\mathrm{CH}_{3}(\mathrm{CO})-\mathrm{COOH}$ и диоксид углерода.

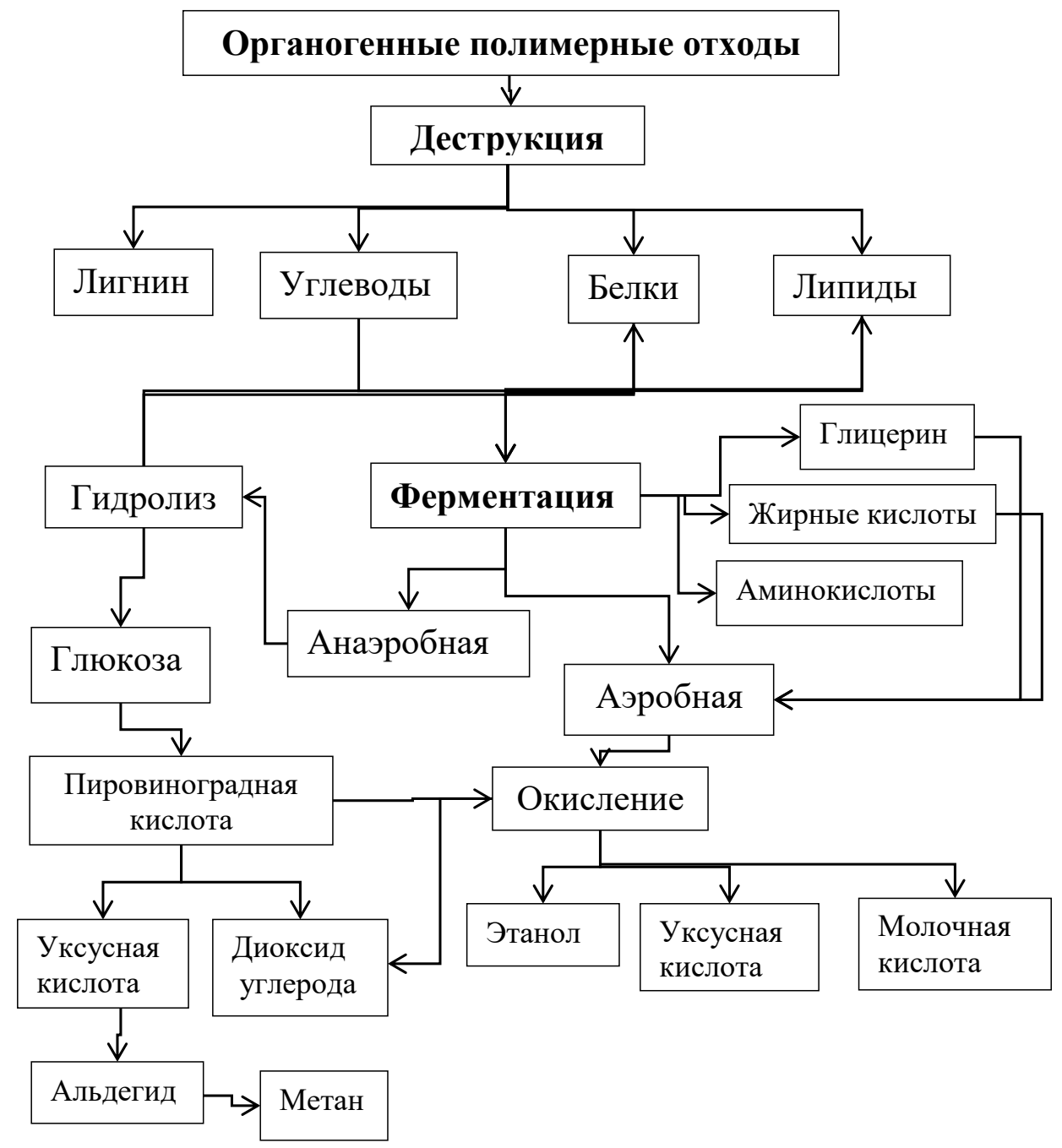

Рис. 4.17. Схема деструкции органогенных отходов 
Второй аэробной стадии при участии ряда ферментов и коферментов, объединенных структурно в мульти ферментную систему (пируватдегидрогеназный комплекс) по круговому циклу (Цикл Кребса ↔ ацетил-КоА). При этом образуются последовательно трикарбоновые (лимонная $\left.\mathrm{HOOCH}_{2} \mathrm{C}-\mathrm{C}(\mathrm{OH})(\mathrm{COOH})-\mathrm{CH}_{2} \mathrm{COOH}\right), \quad$ дикарбоновые: фумаровая $(\mathrm{COOHCH}=\mathrm{CHCOOH})$, щавелевая $(\mathrm{HOOC}-\mathrm{COOH})$ или монокарбоновые уксусная $\left(\mathrm{CH}_{3} \mathrm{COOH}\right)$ кислоты углекислый газ $\mathrm{CO}_{2}$, который соединяясь с щавелевой или уксусной кислоты образует вновь пировиноградную кислоту. Однако, вследствие общих потерь $\mathrm{CO}_{2}$ в цикле, количество этой кислоты и исходного продукта (глюкозы) уменьшается. На третьем этапе биохимическая деструкция пирувата протекает в присутствии фермента пируватдекарбрксилазы в анаэробных условиях (реакции декарбоксилирования) с образованием ацетальдегида $\left(\mathrm{CH}_{3} \mathrm{CHO}\right)$, который в свою очередь разрушается до этанола $\left(\mathrm{C}_{2} \mathrm{H}_{5} \mathrm{OH}\right)$ и диоксида углерода $\left(\mathrm{CO}_{2}\right)$. Конечными продуктами субстрата при анаэробном окислении углеводов специфическими ферментами будут монокарбоновые кислоты (молочная - $\mathrm{CH}_{3}$ $-\mathrm{CH}(\mathrm{OH})-\mathrm{COOH}$ или уксусная - $\left.\mathrm{CH}_{3} \mathrm{COOH}\right)$, либо этанол и $\mathrm{CO}_{2}$ [87, с. 302].

При ферментативном окислении (кислород воздуха) липидов, кроме фермента липаза, принимает участие в окислении и фермент липоксигеназа с образованием смеси высших жирных кислот: линолевой и линоленовой $\mathrm{C}_{18} \mathrm{H}_{32} \mathrm{O}_{2}$, которые в свою очередь окисляются до спиртов, альдегидов, карбоновых кислот. В сложных липидах помимо углерода (C), водорода (Н) и кислорода (O) содержатся другие химические элементы: фосфор (P), сера (S), азот $(\mathrm{N})$, которые участвую в образовании фосфоэфирной (фосфолипидах) или гликозидной связи.

При деструкции этих связей образуются фосфорная кислота, холин $\left[\left(\mathrm{CH}_{3}\right)_{3} \mathrm{~N}^{+} \mathrm{CH}_{2} \mathrm{CH}_{2} \mathrm{OH}\right]$-азотистое основание, этаноламин $\left(\mathrm{HOCH}_{2} \mathrm{CH}_{2}-\mathrm{NH}_{2}\right)$, аминокислота - серин $\left(\mathrm{HO}_{2} \mathrm{C}-\mathrm{CH}\left(\mathrm{NH}_{2}\right)-\mathrm{CH}_{2} \mathrm{OH}\right)$ и другие. 


\section{СТАБИЛИЗАЦИЯ СВОЙСТВ ТОПЛИВНО-ЭНЕРГЕТИЧЕСКИХ СИСТЕМ НА ОСНОВЕ ПРИРОДНЫХ И СИНТЕТИЧЕСКИХ ПОЛИМЕРОВ}

Ферментативный гидролиз липидов протекает при разрушении сложноэфирной группировки под действием экзогенного фермента липазы с образованием глицерина и смеси высших жирных кислот $\left(\mathrm{C}_{14} \ldots \mathrm{C}_{18}\right)$

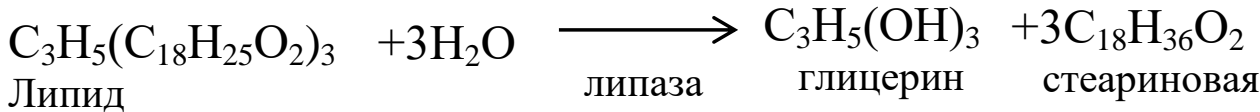

$$
\begin{aligned}
& \text { кислота }
\end{aligned}
$$

В ходе внутриклеточных процессов глицерин окисляется до углекислого газа и воды. Окисление жирных кислот протекает через ряд последовательных реакций отщепления от молекул кислот двух метильных групп $-\mathrm{CH}_{2}$ до образования конечных продуктов углекислого газа и воды.

Белки под действием эндогенных протеолитических ферментов (протеиназ) в кислой среде ( $\mathrm{pH}=4,5 \ldots 5,0)$ и температуре $45 \ldots 50^{\circ} \mathrm{C}$ происходит частичная их деструкция, разрушаются внутренние пептидные связи - $\mathrm{CO}-\mathrm{NH}-$ и образуются преимущественно низкомолекулярные пептиды и небольшое количество свободных аминокислот. Использование при щелочном гидролизе (pH 7...8, температура $40 \ldots 50^{\circ} \mathrm{C}$ ) экзогенных протеолитических ферментов (аминопептидаз, карбоксипептидаз) позволяет наиболее полно осуществить деструкцию пептидных связей и получить свободные аминокислоты. Фермент пепсин расщепляет связь между фенилаланином и тирозином, глутаминовой кислотой и цистином (метионином, глицином), между валином и лейцином. Трипсин расщепляет связь между аргинином (лизином) и другими аминокислотами. Химотрипсин - между ароматическими аминокислотами (триптофан, тирозин, фенилаланин) и метионином. Аминопептидазы действуют со стороны $\mathrm{N}-$ концевой аминокислоты $\left(\mathrm{H}_{2} \mathrm{~N}-\mathrm{RCH}-\mathrm{COOH}\right)$, карбоксипептидазы со стороны C - концевой аминокислоты. Свободные аминокислоты вновь могут вступать в биохимические реакции с образованием новых белков. 
Использование комбинированных методов биоконверсии

целлюлозосодержащих отходов природного или антропогенного происхождения позволило расширить ассортимент полезных продуктов: белки, моносахариды, дрожжи, удобрения, стимуляторы роста растений и другие. В промышленности конверсию целлюлозосодержащего сырья чаще всего проводят с помощью анаэробных микроорганизмов с получением биогаза, удобрений или кормовых добавок.

\section{2 Технологии утилизации углеродсодержащих биополимерных отходов}

Современные технологии утилизации углеродсодержащих отходов основаны на термохимических методах конверсии (пиролиз) или биотехнологических методах с использованием микроорганизмов с получением эффективных энергоносителей: синтез газ, этанол, бутанол, биогаз [88 - 90].

В зависимости от природы катализатора и условий газификации ЦО можно усовершенствовать качество топливного материала, преобразованием синтез газа в моторное топливо (синтетический бензин), и повысить производительность газогенератора. Генератор газификации представляет собой модифицированный дизельный двигатель, в котором синтез-газ, полученный из ЦО, преобразуются в моторное топливо через стадию получения метанола (рис. 4.18) по пути 1, либо по пути 2 минуя ее. Преобразование метана в синтез газ протекает по следующим химическим реакциям:

$$
\mathrm{CH}_{4}+\mathrm{H}_{2} \mathrm{O} \leftrightarrow \mathrm{CO}+3 \mathrm{H}_{2} \text { или } \mathrm{CH}_{4}+1 / 2 \mathrm{O}_{2} \leftrightarrow \mathrm{CO}+2 \mathrm{H}_{2} .
$$

Чем выше температура газификации, тем выше степень превращения метана в синтез-газ, тем выше производительность реактора.

При температуре более $1400^{\circ} \mathrm{C}$ метан разлагается с образованием этилена и водорода по реакции 


$$
2 \mathrm{CH}_{4} \rightarrow \mathrm{C}_{2} \mathrm{H}_{2}+3 \mathrm{H}_{2} .
$$

Использование специфических катализаторов $\left(\mathrm{Ni} / \mathrm{Al}_{2} \mathrm{O}_{3}\right)$ позволяет снизить температуру с $1400 \ldots 1600^{\circ} \mathrm{C}$ до $800 \ldots 900^{\circ} \mathrm{C}$ и ускорить процесс преобразования легких углеводородов $(\mathrm{CmHn})$, например, метана $\left(\mathrm{CH}_{4}\right)$ в жидкие органические соединения метанол и диметиловый эфир, а затем в моторное топливо (бензин, керосин, гайзоль).

Проведение реакции получения диметилового эфира (ДМЭ), минуя стадию образования метанола по пути 2, позволяет повысить содержание октанового (92) и цетанового (55...60) чисел, улучшить запуск холодного двигателя, снизить расход кислорода при сгорании топлива. Однако теплотворная способность топлива на основе ДМЭ уступает традиционному дизельному топливу (на основе пропана или бутана). В результате полученный синтетический бензин в 1,8 ... 2,0 раза дороже "нефтяного".

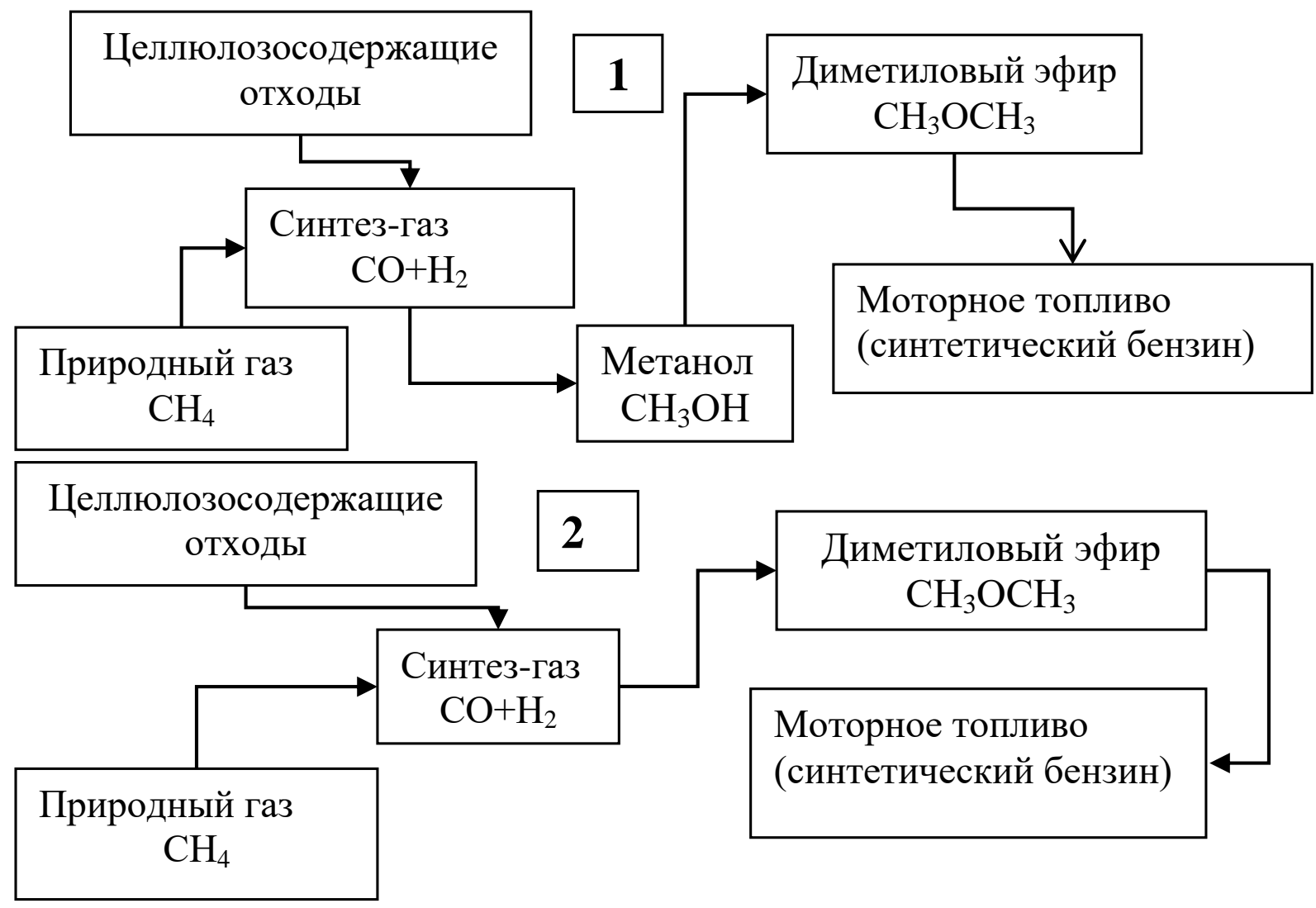

Рис. 4.18. Схемы преобразования синтез газа в моторное топливо 


\section{СТАБИЛИЗАЦИЯ СВОЙСТВ ТОПЛИВНО-ЭНЕРГЕТИЧЕСКИХ СИСТЕМ НА ОСНОВЕ ПРИРОДНЫХ И СИНТЕТИЧЕСКИХ ПОЛИМЕРОВ}

Газификация низкокалорийного органогенного сырья (бурого угля) под давлением в стационарном слое при совместной подаче пара и кислорода в газогенератор позволяет получить синтез-газ, состоящий из метана $(9 \ldots 11 \%)$, оксида углерода $(15 \ldots 18 \%)$, водорода $(38 \ldots 40 \%)$ и диоксида углерода (30...32\%) [91, с. 116]. С повышением температуры увеличивается доля СО, с возрастанием давления $-\mathrm{H}_{2}$ и $\mathrm{CH}_{4}$. Трудности газификации таких отходов связаны с их малой насыпной плотностью, высокой зольностью, высокими температурами, повышенным содержанием угле подобного остатка. В присутствии катализаторов можно снизить температуру газификации [92] и получить жидкие или твердые смеси углеводородов, близкие по химическому составу к продуктам фракционирования нефти. Газификация целлюлозосодержащих отходов (биомасса) с получением генераторного газа (рис. 4.19) актуальна для производства тепловой энергии (4,6..6,3 мДж) в районах, удаленных от электрических и газовых сетей [93 - 95].

Промышленные конструкции газогенераторов представляет собой модифицированный дизельный двигатель, просты и компактны, эффективны, экономичны (окупаются в течение $2 \ldots 3$ лет). Затраты на оборудование составляют менее 1000 \% на 1 кВт получаемой электроэнергии. На выработку 1 кВт электроэнергии требуется примерно $1,3 \ldots 1,8$ кг рисовой шелухи (соломы) или 1,1..1,6 опилок (или лигнина). Повысить производительность единичного газогенератора газификации можно при эксплуатации параллельных газогенераторов, что приводит к дополнительным затратам. Общим недостатком газификации твердых целлюлозосодержащих и органогенных отходов являются высокие температуры деструкции, низкий выход ( $\approx 30 \%)$ генераторного газа. 


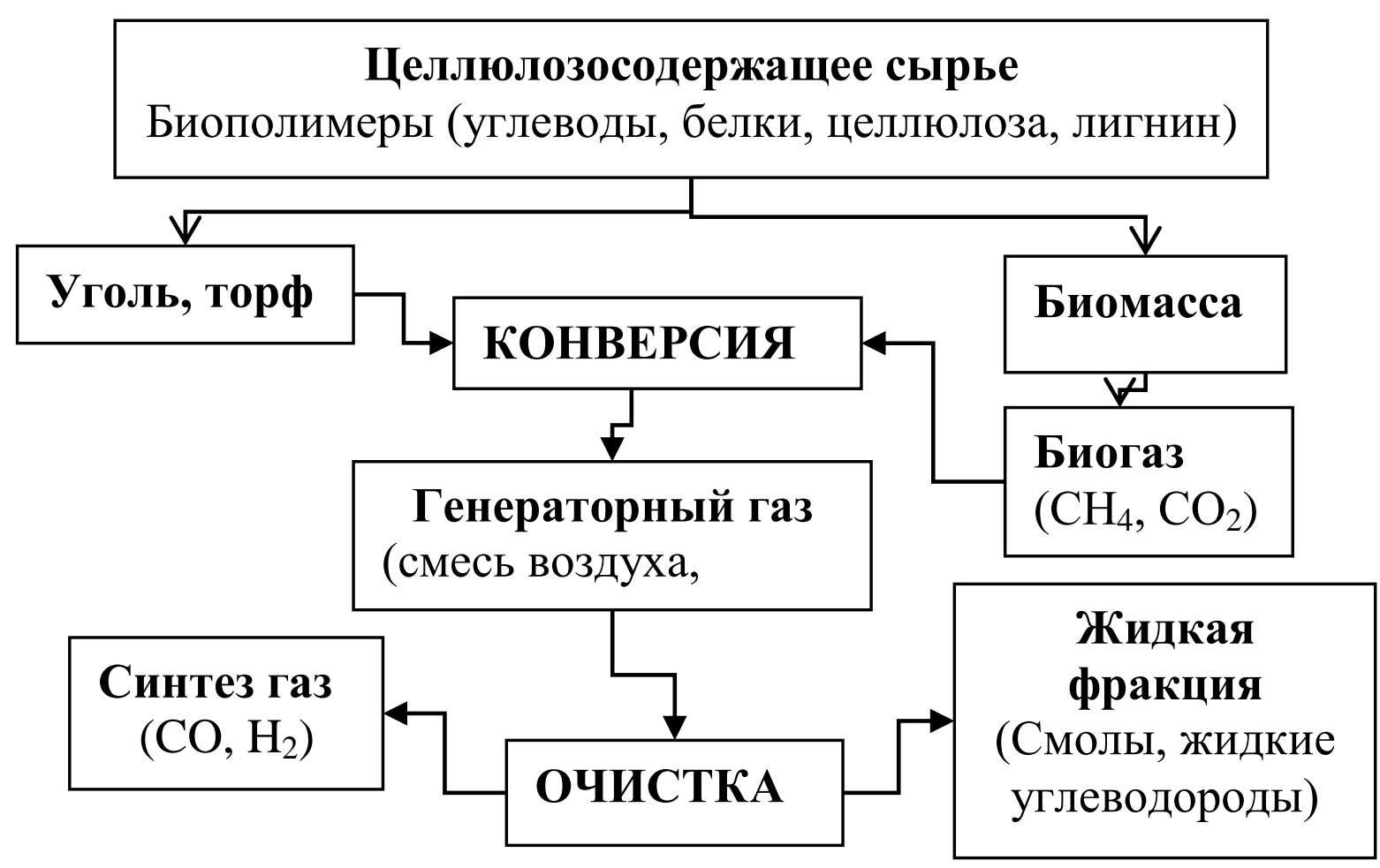

Рис. 4.19. Схема газификации целлюлозосодержащего сырья

Традиционная технологическая схема биоконверсии ЦО включает предферментацию и ферментацию (рис.4.20). На стадии предферментации происходит подготовка питательной среды, посевного материала, оборудования, воспроизводство микроорганизмов. По своему назначению питательные среды делят на диагностические и производственные. Диагностические питательные среды предназначены для обнаружения, выделения и идентификации патогенных микроорганизмов по морфологическим и физиологическим признакам. Различают элективные среды (для посева тест штамма и получения чистой культуры), среды обогащения (накопление одной группы микроорганизмов при одновременной задержке роста сопутствующих микроорганизмов), среды консервирования (для хранения), дифференциально-диагностические (для идентификации видов). Состав питательных сред подбирают на основании материального баланса с учетом трансформации элементов питания расходуемой (выделяемой энергии). 


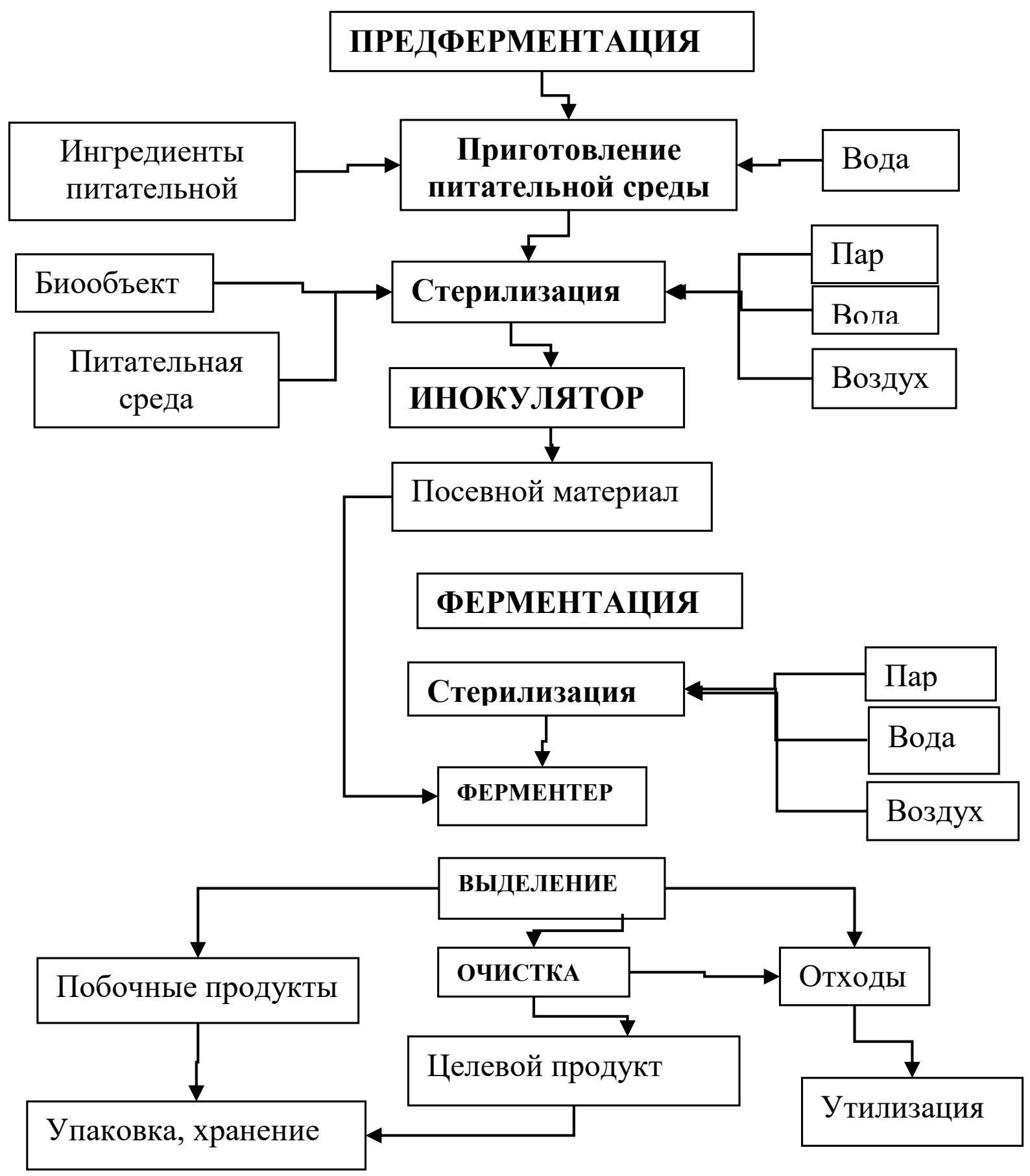

Рис. 4.20. Обобщенная схема биоконверсии

Для получения заданного количества биомассы компоненты питательной среды берутся в соотношениях, пропорциональных потребностям их культур:

$$
\frac{\mathrm{C}_{1}}{\mathrm{~A}_{1}}=\frac{\mathrm{C}_{2}}{\mathrm{~A}_{2}}=\cdots \frac{\mathrm{C}_{i}}{\mathrm{~A}_{i}}=S_{0},
$$




\section{СТАБИЛИЗАЦИЯ СВОЙСТВ ТОПЛИВНО-ЭНЕРГЕТИЧЕСКИХ СИСТЕМ НА ОСНОВЕ ПРИРОДНЫХ И СИНТЕТИЧЕСКИХ ПОЛИМЕРОВ}

где $-\mathrm{C}_{1}, \mathrm{C}_{2} \ldots \mathrm{C}_{\mathrm{i}}$ - концентрация компонентов в сбалансированной питательной среде; $\mathrm{A}_{1}, \mathrm{~A}_{2} \ldots \mathrm{A}_{\mathrm{i}}$ - коэффициент метаболизма культуры по i-му компоненту;

$\mathrm{S}_{0}$ - заданный запас субстрата в среде, выраженный в единицах концентрации биомассы [96].

Выбор и подготовка посевного материала осуществляется в два этапа: лабораторного и производственного. В основе выбора посевного материала лежат принципы принадлежности биообъекта к надцарствам живых существ: прокариотам (аэробные и анаэробные бактерии), эукариотам (водоросли, грибы, простейшие); функциональной активностью биообъекта (биосинтез, биотрансформация).

Лабораторный этап заключается в приготовлении рабочего посевного материала путем оживления исходного штамма, находящегося в состоянии анабиоза, и постепенного наращивания биомассы, переходя от пробирок к емкостям большеного объема $\left(1\right.$ дм $^{3}, 20$ дм³ $^{3}$. При этом следует соблюдать соотношение посевного материала и рабочего объема раствора 1:10. Коэффициент заполнения емкостей не должен превышать $0,5 \ldots 0,7$. Производственный этап - стадия ферментации осуществляют в инокуляторах объемом $\left(0,63 \ldots 10 \mathrm{~m}^{3}\right)$ диаметром $(0,9 \ldots 2,0$ м), с частотой перемешивания (180...270 оборотах в минуту) при поддержании оптимальных параметров культивирования. Производственные (натуральные и синтетические) питательные среды имеют неопределенный состав и предназначены для поддержания жизнедеятельности или наращивания биомассы микроорганизмов. На стадии ферментации происходит накопление конечных (целеввых и побочных продуктов), их выделение, утилизация отходов. В составе органических остатков микроорганизмов преобладают белки и нуклеиновые кислоты. Параметры контроля биоконверсии: температура, $\mathrm{pH}$ среды, биомасса клеток, скорость потребления источников питания, количество и состав метаболитов. 


\section{СТАБИЛИЗАЦИЯ СВОЙСТВ ТОПЛИВНО-ЭНЕРГЕТИЧЕСКИХ СИСТЕМ НА ОСНОВЕ ПРИРОДНЫХ И СИНТЕТИЧЕСКИХ ПОЛИМЕРОВ}

Преимущество микробиологического способа биоконверсии

основываются на возможности вычленения отдельных этапов из биотехнологических схем производства в виде самостоятельных процессов (подготовка питательных сред и оборудования, ферментация, стерилизация сред и оборудования). К недостаткам традиционной технологии биоконверсии можно отнести: многокомпонентность питательных сред; необходимость стерилизации питательных сред, оборудования и коммуникаций для удаления или разрушения контаминантов (патогенных микроорганизмов) при сохранении качества среды, а также трудности в управлении процессом биосинтеза и автоматизации.

\subsection{1 Разработка эффективной технологии биоконверсии твердых биополимерных отходов}

Обобщенный анализ механизма анаэробной биоконверсии органогенных полимеров позволяет выдвинуть гипотезу о протекании последовательных биохимических превращений в два этапа. На первом этапе протекает ферментативный гидролиз биополимеров $\mathrm{c}$ образованием глюкозы и органических кислот и рост биомассы микроорганизмов. На втором этапе идет деструкция органических кислот ( $252 \%)$ до образования воды, газов: метан $\left(\mathrm{CH}_{4}\right)$, диоксида углерода $\left(\mathrm{CO}_{2}\right)$, оксида углерода $(\mathrm{CO})$, водорода $\left(\mathrm{H}_{2}\right)$ или сероводорода $\left(\mathrm{H}_{2} \mathrm{~S}\right)$ и твердого углеродсодержащего остатка. После очистки биогаза от $\mathrm{CO}_{2}$ получается биометан - аналог природного газа. Выход биогаза зависит от содержания сухого вещества, вида и состава используемых отходов, условий ферментации и штаммов микроорганизмов.

При анаэробной ферментации бытовых сточных вод в кислой среде (pH 4,0..6,5) образуется твердая фракция (активный ил), которую используют в качестве органического удобрения. Жидкая фракция содержит смесь уксусной $\left(\mathrm{CH}_{3} \mathrm{COOH}\right), \quad$ пропионовой $\left(\mathrm{CH}_{3} \mathrm{CH}_{2} \mathrm{COOH}\right), \quad$ масляной 
$\left(\mathrm{CH}_{3}\left(\mathrm{CH}_{2}\right)_{2} \mathrm{COOH}\right)$ кислот, а газообразная фракция - диоксид углерода, водород. При анаэробной ферментации агропромышленного отхода навоза, содержащего биополимеры (белки, липиды) в нейтральной или слабощелочной среде $(\mathrm{pH}=7,0 \ldots 7,8)$ получают органическое удобрение повышенной биологической активности и биогаз (23 МДж/м $\left.{ }^{3}\right)$. Степень деструкции органического вещества навоза не превышает $47 \%$.

Основным преимуществом анаэробной ферментативной утилизации биополимерных отходов от других систем утилизации является минимальная затрата энергии на процесс ферментации и производство дополнительной энергии в виде биогаза. Установка занимает небольшую площадь и, благодаря герметичности ферментеров, в атмосферный воздух не выделяются токсичные выбросы.

Для повышения эффективности инструментариев и сокращении времени деструкции ЦО разработана технология утилизации биополимерных отходов с получением биогаза [97, с. 56]. Используются не специфические штаммы микроорганизмов, а консорциум эффективных микроорганизмов ( $\approx 80$ видов) биологически активного препарата «Тамир» (рис. 4.21). Препарат «Тамир» разработан на основе японского аналога «Waste Treatment» и предназначен для ускоренной утилизации бытовых и сельскохозяйственных отходов (остатков пищи, ботвы, сорных растений), а также для восстановления дренажа, устранения неприятных запахов.

Данная технология включает использование целлюлозосодержащих отходов и почвы, введение микроорганизмов, увлажнение и инкубацию. Отходы сортируют и измельчают в мельнице до размера частиц 1 . . 2 см для увеличения удельной поверхности контакта микроорганизмов с частицами твердофазного субстрата, оптимизации теплового и массового обмена. Измельченные частицы ЦО с помощью шнека загружают в ферментер, чередуя слои ЦО и почвы. Высота каждого слоя 2 ... 3 см. После чего твердофазный субстрат обрабатывают суспензией консорциума ЭМ, полученной 164 
культивацией микроорганизмов препарата «Тамир» без доступа воздуха при температуре $20 \ldots 40^{\circ} \mathrm{C}$ в течение 120 дней. Заданные условия наиболее благоприятны для функционирования мезофильных видов микроорганизмов, входящих в состав суспензии. Культивирование ЭМ осуществляют в инокуляторе с добавлением в него воды, сахара и препарата Ургаса в соотношении - вода: концентрат Тамира : сахар : препарат Ургаса - 30:0,3:1:0,5 при периодическом перемешивании (один раз в сутки в течении $1 \ldots 2$ мин). Технический результат, заключается в упрощении технологии приготовления и сокращении сроков гумификации техногенной почвы [98].

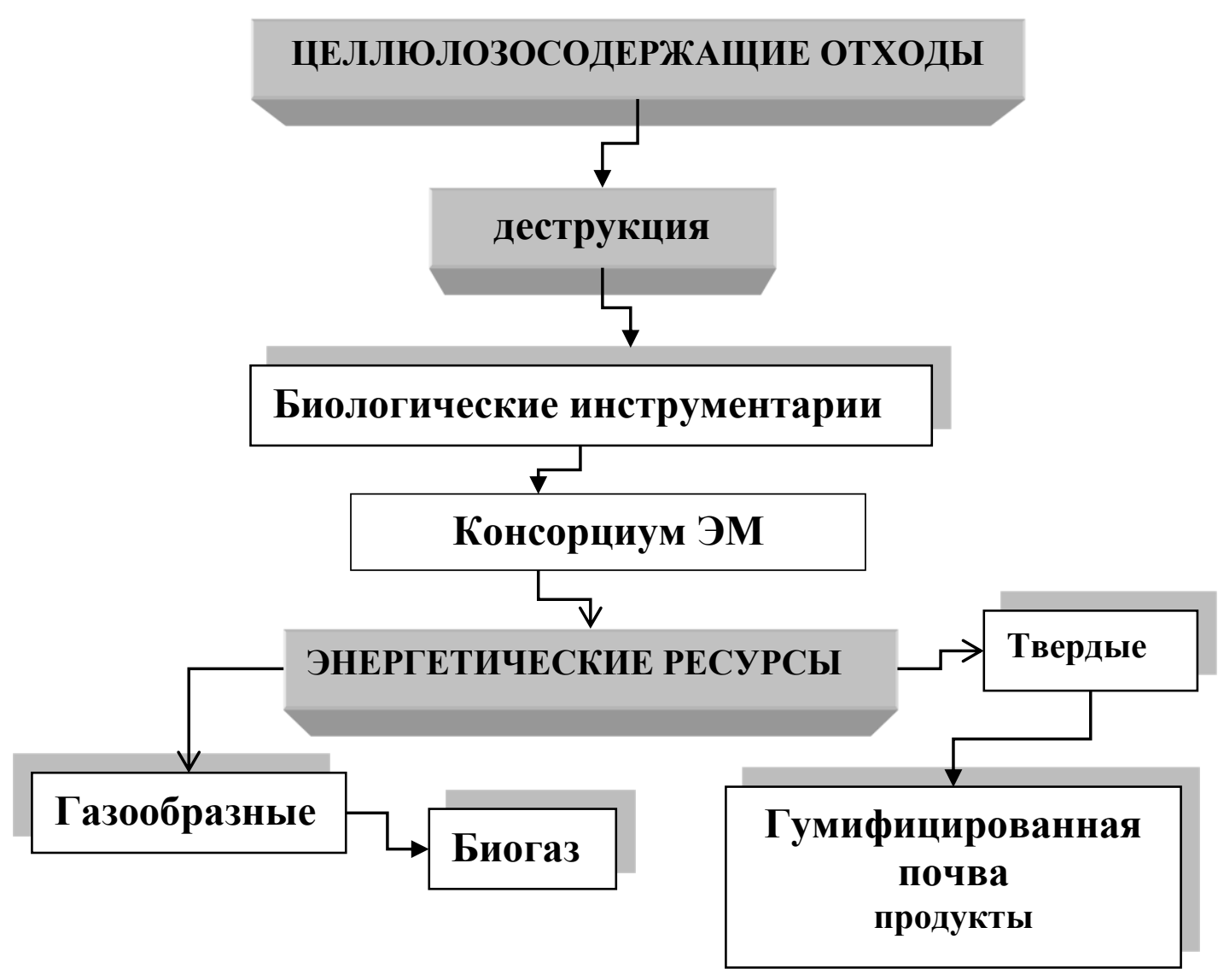

Рис. 4.21. Схема получения возобновляемых энергетических ресурсов

Исследования процесса анаэробной ферментации, проведенные на лабораторной установке (рис. 4.22), созданной на кафедре «Энергообеспечение предприятий и электротехнологии» ФГБОУ ВО СПбГАУ, показали, что на 
образование биогаза влияют температура процесса, $\mathrm{pH}$ среды и состав рабочего раствора эффективных микроорганизмов [99].

В качестве сырья использовали ЦО промышленные (опилки); бытовые (высушенные после заварки листья чая, картон); агропромышленные (солома ячменя). Деструкцию осуществляли в мезофильных условиях $\left(20 \ldots 40^{\circ} \mathrm{C}\right)$ в течение $10 \ldots 30$ суток. В процессе производства поддерживается постоянное значение $\mathrm{pH} \approx 7,0$ за счет нейтрализации образовавшихся кислот при взаимодействии с диоксидом углерода и образованием соответствующих солей (карбонатов). Корректировку рН при значении ниже 6,5 проводят добавлением извести.

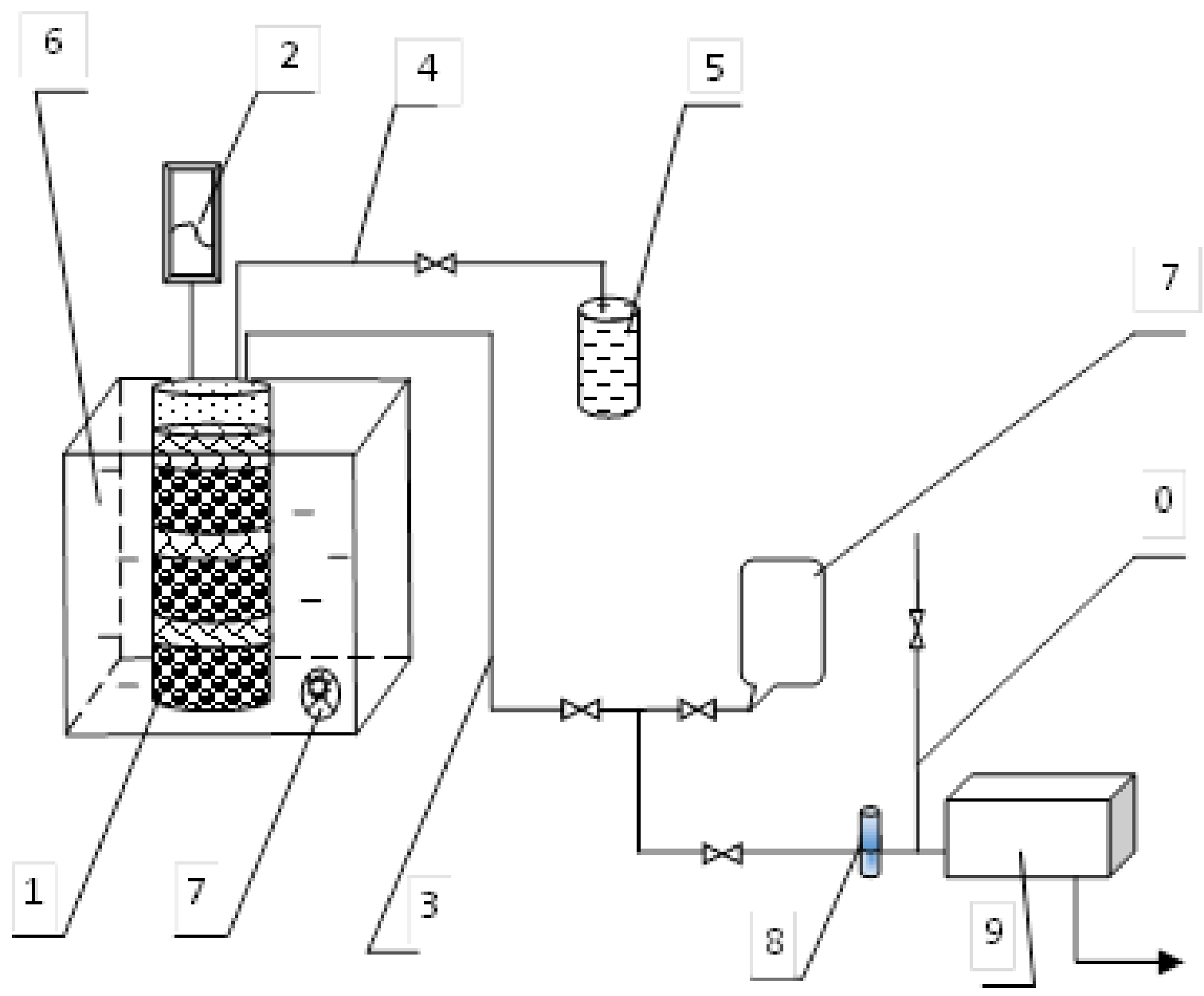

Рис. 4.22. Схема установки для переработки твердых отходов:

1- ферментер; 2- термометр и рН-метр; 3, 4 - трубопроводы выхода биогаза и подачи рабочих растворов; 5 - газгольдер; 6 - водяная баня; 7 - терморегулятор; 8 -ротаметр; 9 - газоанализатор 


\section{СТАБИЛИЗАЦИЯ СВОЙСТВ ТОПЛИВНО-ЭНЕРГЕТИЧЕСКИХ СИСТЕМ НА ОСНОВЕ ПРИРОДНЫХ И СИНТЕТИЧЕСКИХ ПОЛИМЕРОВ}

Интервал изменения температур ферментации $\left(20 \ldots 40^{\circ} \mathrm{C}\right)$ был выбран по условию прохождения процесса ферментации твердых ЦО: при температуре ниже $20^{\circ} \mathrm{C}$ процесс ферментации резко замедляется, при температуре выше $40^{\circ} \mathrm{C}$ скорость ферментации также замедляется. В результате деструкции ЦО получены гумицированная почва и биогаз [23, с. 144]. Анаэробная ферментация целлюлозосодержащих отходов (ЦО) с использованием консорциума ЭМ позволила ускорить деструкцию целлюлозы до биогаза, а лигнина до гумусовых веществ.

В связи с тем, что практически 70 \% всего метана образуется из уксусной кислоты, то механизм ферментативного гидролиза ЦО можно представить в виде системы последовательных химических реакций:

$$
\begin{gathered}
\left(\mathrm{C}_{6} \mathrm{H}_{10} \mathrm{O}_{5}\right)_{n} \rightarrow \mathrm{nC}_{6} \mathrm{H}_{12} \mathrm{O}_{6} \rightarrow \mathrm{CH}_{3} \mathrm{COOH}+\mathrm{CH}_{3} \mathrm{OH}+\mathrm{CO}_{2}+\mathrm{H}_{2} \mathrm{O}+\mathrm{H}_{2} \\
\mathrm{CH}_{3} \mathrm{COOH} \rightarrow \mathrm{CH}_{4}+\mathrm{CO}_{2} \\
4 \mathrm{CH}_{3} \mathrm{OH} \rightarrow 3 \mathrm{CH}_{4}+\mathrm{CO}_{2}+\mathrm{H}_{2} \mathrm{O} \\
\mathrm{H}_{2}+\mathrm{CO}_{2} \rightarrow \mathrm{CH}_{4}+2 \mathrm{H}_{2} \mathrm{O} .
\end{gathered}
$$

Bсе побочные реакции метаболического превращения можно представить брутто реакцией образования метана

$$
\mathrm{CO}_{2}+4 \mathrm{H}_{2} \mathrm{~A} \rightarrow \mathrm{CH}_{4} \uparrow+4 \mathrm{~A}+2 \mathrm{H}_{2} \mathrm{O} .
$$

Удельный выход биогаза $\mathrm{G}_{\text {бг }}, \mathrm{M}^{3} /$ кг из ЦО на основной стадии можно определить в зависимости от содержания органической компоненты $\mathrm{M}_{\mathrm{c}}$ и физических свойств - влажности и температуры отходов, по эмпирической зависимости

$$
\mathrm{G}_{\sigma \Gamma}=\frac{\mathrm{M}_{\mathrm{c}}\left(1-\mathrm{e}^{-k \tau}\right)}{\left(\frac{59-\mathrm{W}}{13}\right)^{4}},
$$

где $\mathrm{W}$ - влажность отходов, \%; $k$ - постоянная разложения, равная отношению углерода к общему азоту $(\mathrm{C} / \mathrm{N}), \boldsymbol{\tau}$ - продолжительность периода стадии, год.

Содержание органической компоненты $\mathrm{M}_{\mathrm{c}}$ определяется по формуле

$$
\mathrm{M}_{\mathrm{c}}=1,868 C_{\text {aкm }}(0,014 T+0,28),
$$


где $C_{a \kappa m}$ - активный органический углерод, г/кг отходов; $T$ - температура в теле полигона, ${ }^{\circ} \mathrm{C}$, которая колеблется от 28 до $32{ }^{\circ} \mathrm{C}$.

Для практических расчетов можно использовать уравнение выхода биогаза при метановом брожении

$$
\mathrm{M}_{\text {бг }}=10^{-6} \mathrm{R}(100-\mathrm{W}) \cdot(0,92 Ж+0,62 \mathrm{y}+0,34 \text { Б), }
$$

где $\mathrm{M}_{\text {бг }}$ - удельный выход биогаза за период активного выхода, кг/кг отходов;

$W$ - средняя влажность отходов, \%; $R$ - содержание органической составляющей в отходах, на сухую массу, \%; Ж - содержание жироподобных веществ в отходах, \%; $У$ - содержание углеводных веществ в отходах, \%;

5 - содержание белковых веществ в отходах, \%.

Значения $\mathrm{W}, \mathrm{R}$, Ж, У и Б - определяются анализами отбираемых проб отходов.

Так как процесс ферментации может идти только в определенных объемах - сочетания отходов и микроэлементов, то в расчетах выхода биогаза учитывается оптимальная высота слоя биотходов коэффициентом $0,5 \ldots 0,4$.

Выход биогаза кг/кг отходов в год можно определить, зная плотность биогаза по формуле

$$
\mathrm{M}_{\mathrm{b}}=0,8 \mathrm{G}_{\text {бг }} \rho_{\text {бг }} / \tau
$$

или

$$
\mathrm{M}_{\mathrm{b}}=800 \mathrm{M}_{б г} / \tau .
$$

Состав биогаза и концентрации компонентов в нем определяются анализами проб биогаза. Плотность биогаза определяется по закону аддитивности, как средневзвешенная величина из плотностей всех его компонентов

$$
\rho_{\text {б }}=\frac{\sum_{i=1}^{n} c_{\mathrm{B} i} \rho_{i}}{100}
$$

где $C_{6 i}-$ весовое содержание і-того компонента в биогазе, \%; $\rho_{i}-$ плотность i-того компонента биогаза, кг $/ \mathrm{M}^{3} ; n-$ количество компонентов в биогазе. 
Средняя плотность биогаза составляет обычно $0,95 \ldots 0,98$ плотности

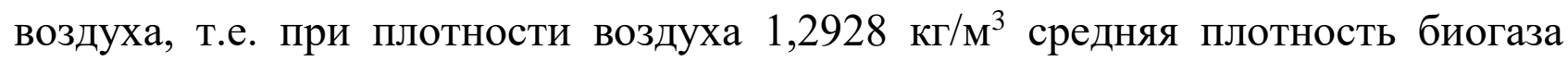
составит

$$
1,2928 * 0,965=1,24755 \mathrm{\kappa} / \mathrm{M}^{3} .
$$

С другой стороны, связь плотности биогаза, концентраций в нем компонентов и их весового процентного содержания определяются формулой

$$
\mathrm{C}_{\mathrm{B}}=\frac{10^{-4} C_{i}}{\rho_{6}},
$$

где $C_{i}$ - концентрация і-того компонента в биогазе, мг $/ \mathrm{M}^{3}$.

Решая совместно уравнения (4.24) и (․․25), получим формулу для

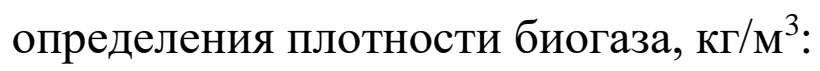

$$
\rho_{\text {б }}=10^{-3} \sqrt{\sum_{i=1}^{n} C_{i} \rho_{i}} .
$$

Для контроля расхода биогаза газгольдер устанавливается на весы. Проба биогза отбирается из газгольдера с помощью насоса, встроенного в газоанализатор ГИАМ. При отборе проб ротаметром измеряется скорость движения биогаза, время отбора пробы измеряется секундомером, таким образом, определялся расход биогаза. Концентрация метана в биогазе определяется газоанализатором ГИАМ, а затем рассчитывается количество метана во всем объеме биогаза. Выход биогаза и метана в выделенных зонах будет возрастать с течением времени (рис.4.23).

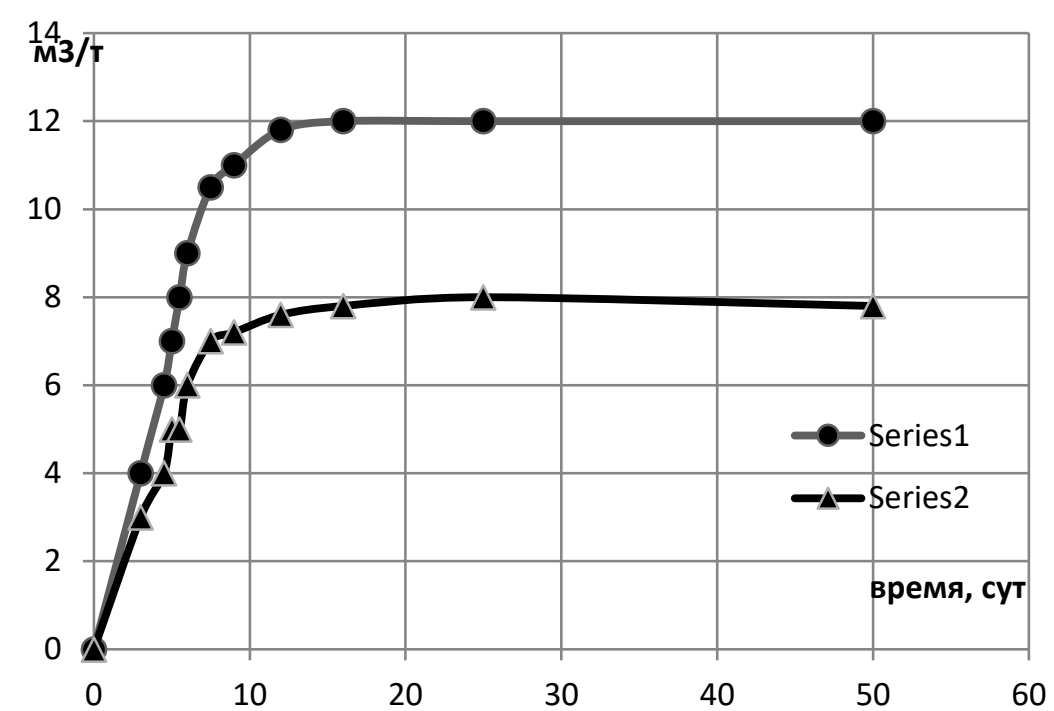

Рис. 4.23. Выход и состав биогаза в зависимости от времени брожения при температуре 50ㅜㄹ: Ряд 1 - выход биогаза, ряд 2 - выход метана 


\subsection{2 Оценка влияния параметров процесса биоконверсии твердых отходов на состав образовавшегося биогаза}

Оценку комплексного влияния параметров ферментации и проведения многофакторного эксперимента проводили с помощью рототабельного плана Бокса-Бенкина второго порядка, минимизирующий число экспериментов при одновременном варьировании изучаемых факторов (табл. 4.2). За параметры варьирования в закодированном виде приняты: $\mathrm{X}_{1}$ - температура в процессе биоконверсии; $\mathrm{X}_{2}$ - концентрация лигнина в ЦО; $\mathrm{X}_{3}$ - концентрация Тамира в суспензии ЭМ. За критерий оптимизации $\mathrm{V}_{1}, \mathrm{y}_{2}$ принято содержание метана в биогазе и контрольное содержание оксида углерода в биогазе [23, с. 160]. Измерения температуры и $\mathrm{pH}$ среды в ферментере проводятся периодически, один раз в сутки.

В ферментер установлены термометр и $\mathrm{pH}$-метр (2), а также трубопроводы для выхода биогаза (3) и для подачи рабочих растворов (4, рис.4.22). Для поддержания температуры процесса биоконверсии ферментер (1) помещается в водяную баню (6), имеющую терморегулятор (7). Трубопровод (3) соединяет ферментер с емкостью для сбора газа газгольдером 5, а затем через ротаметр (8) с газоанализатором (9). Расход биогаза регулируется кранами, установленными в трубопроводе 3. Для измерения концентрации метана в биогазе проба биогаза разбавлялась воздухом при ее поступлении в газоанализатор.

Таблица 4.2

Интервалы варьирования переменных трехфакторного эксперимента

\begin{tabular}{|l|c|c|c|}
\hline $\begin{array}{c}\text { Кодированное значение } \\
\text { факторов }\end{array}$ & $\begin{array}{c}\mathrm{X}_{1} \\
\text { температура, } \\
{ }^{0} \mathrm{C}\end{array}$ & $\begin{array}{c}\mathrm{X}_{2} \\
\text { состав } \\
\text { отходов ЦО } \\
(Л), \%\end{array}$ & $\begin{array}{c}\mathrm{X}_{1} \\
\text { состав } \\
\text { суспензии ЭМ } \\
(\mathrm{T}), \%\end{array}$ \\
\hline Верхний уровень $(+)$ & 20 & 5 & 0,1 \\
\hline Основной уровень $(0)$ & 30 & 20 & 0,3 \\
\hline Нижний уровень (-) & 40 & 35 & 0,5 \\
\hline
\end{tabular}




\section{СТАБИЛИЗАЦИЯ СВОЙСТВ ТОПЛИВНО-ЭНЕРГЕТИЧЕСКИХ СИСТЕМ НА ОСНОВЕ ПРИРОДНЫХ И СИНТЕТИЧЕСКИХ ПОЛИМЕРОВ}

Предварительными исследованиями установлены возможные интервалы значений основных параметров:

- температура ферментации $20-40^{\circ} \mathrm{C}$;

- состав исходного ЦО по содержанию лигнина (Л) и целлюлозы (Ц):

- картон - 26\% Л + 48\% Ц от общего состава или 35: 65;

- опилки - 3\% Л + 63\% Ц от общего состава или 5:95;

- спитой чай - 10\% Л + 50\% Ц от общего состава или 20:80;

- состав рабочего раствора эффективных микроорганизмов по основному компоненту препарата «Тамир» $0,1-0,5$.

При расчете материального баланса технологического процесса биологической деструкции твердых целлюлозосодержащих отходов в биогазовой установке принимались следующие условия: процесс происходит без испарения воды; начальная масса микроорганизмов $\left(\mathrm{M}_{0}\right)$ равна массе $\mathrm{M}_{\text {эм в }}$ рабочем растворе препарата «Тамир». В процессе ферментации происходит наращивание биомассы ЭМ с уменьшением концентрации элементов питания. В конце ферментации субстрат содержит только воду и микроорганизмы; потери на каждой стадии процесса составляют - при выращивании микроорганизмов $\Pi_{\mathrm{I}}=5 \%$, при разбавлении рабочего раствора жидкости $\Pi_{\text {II }}=$ $0,5 \%$, при гумификации $\Pi_{\mathrm{III}}=5 \%$, при упаковке $\Pi_{\mathrm{IV}}=0,5 \%$; для ускорения процесса содержимое ферментера нагревают горячей водой через рубашку. Результаты расчета масс веществ до выращивания микроорганизмов представлены в таблице 4.3 .

Таблица 4.3

Результаты расчета баланса технологического процесса биоконверсии твердых отходов в биогазовой установке

\begin{tabular}{|c|c|l|}
\hline \multirow{2}{*}{ Вещество } & \multicolumn{2}{|c|}{ Масса, кг } \\
\cline { 2 - 3 } & Обозначение & Значение \\
\hline Вода & $M_{\text {II в }}$ & 1997,05 \\
\hline Микроорганизмы & $M_{\text {II мо }}$ & 78 \\
\hline Земля & $M_{3}$ & 722,22 \\
\hline Гумус & $M_{\Gamma}$ & 528,84 \\
\hline Газ & $M_{H}$ & 154,90 \\
\hline Общая масса & $\mathrm{M}_{\text {III }}$ & 3481,03 \\
\hline
\end{tabular}




\section{СТАБИЛИЗАЦИЯ СВОЙСТВ ТОПЛИВНО-ЭНЕРГЕТИЧЕСКИХ СИСТЕМ НА ОСНОВЕ ПРИРОДНЫХ И СИНТЕТИЧЕСКИХ ПОЛИМЕРОВ}

Процесс получения тепловой и электрической энергии из биогаза можно представить схемой, состоящей из двух модулей - модуль получения биогаза метантек и технологическое оборудование [23, с. 185] и модуль когенерационной установки с технологическим оборудованием (рис. 4.24).

Для построения когенерационного модуля в качестве наиболее перспективного агрегата используется газопоршневая установка, на базе двигателей ЯМЗ и ТМЗ. Газопоршневая установка относится к установкам с относительно простотой системой обслуживания и управления, низкой стоимости и высоким показателей полного КПД (сумма электрического и теплового КПД). При использовании биогаза в качестве топлива возникает ряд технических задач, связанных с его составом и физико-химическими свойствам. По сравнению с другими газами, биогазу нужно меньше воздуха для возгорания.

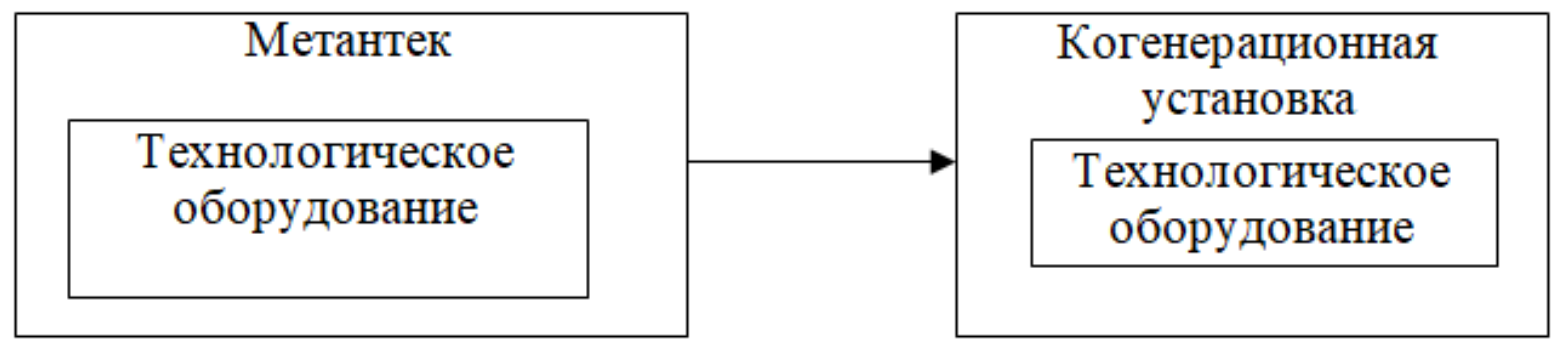

\section{Рис. 4.24. Схема получения тепловой и электрической энергии из биогаза}

Полученную в результате анаэробной ферментации ЦО с использованием консорциума эффективных микроорганизмов препарата «Тамир» почву исследовали на возможность дальнейшего ее использования для повышения продуктивности растений. Интегрированную оценку качества полученной почвы проводили биотестированием. Эффективность гумифицирующего эффекта почв оценивали по биометрическим показателям качества тест культур. При внесении в техногенную почву гумифицированной почвы улучшились биометрические показатели качества дерново-подзолистой почвы. 


\section{СТАБИЛИЗАЦИЯ СВОЙСТВ ТОПЛИВНО-ЭНЕРГЕТИЧЕСКИХ СИСТЕМ НА ОСНОВЕ ПРИРОДНЫХ И СИНТЕТИЧЕСКИХ ПОЛИМЕРОВ}

Ускорилось корнеобразование, всхожесть тест растений возросла в $2 \ldots .5$ раз, коэффициент фитотоксичности по абсолютной величине вырос в восемь раз, урожайность зерновых и кормовых культур увеличилась на $10 \ldots .50 \%$. Полученные результаты позволили сформулировать гипотезу стабилизации качества природных и техногенных дерново-подзолистых почв продуктом биоконверсии ЦО [20, с. 138; 23, с. 106; 100, с. 134; 101, с. 139].

Разработанная методология утилизации полимерных твердых техногенных отходов на основе синтетических и природных полимеров с получением вторичного сырья позволила не только решить экологические проблемы: минимизации техногенных риска; регенерации почв, но и расширить сырьевую базу для получения ассортимента полезных продуктов, используемых в энергетике и агропромышленном комплексе. Газообразные продукты деструкции (биогаз) твердых органических отходов рекомендуется использовать в качестве возобновляемого энергетического ресурса для когенерационных установок, представляющих собой оборудование для комбинированного производства электроэнергии и теплоты. Преимуществом малых установок является надежность, инерционность, возможность вырабатывать необходимое количество энергии в непосредственной близости от потребителя. Гумифицированную почву рекомендуется использовать для рекультивации техногенных почв.

\section{3 Модульные системы энергообеспечения}

Преимущества и перспективы применения поршневых газовых двигателей внутреннего сгорания для комбинированной выработки электрической и тепловой энергии обусловлены происходящими в Российской Федерации процессами: либерализация энергетического рынка, высокие затраты на подключение и кризис в эксплуатации крупных систем централизованного энергоснабжения. 


\section{СТАБИЛИЗАЦИЯ СВОЙСТВ ТОПЛИВНО-ЭНЕРГЕТИЧЕСКИХ СИСТЕМ НА ОСНОВЕ ПРИРОДНЫХ И СИНТЕТИЧЕСКИХ ПОЛИМЕРОВ}

Актуальность этого направления определяется также тем, что около $30 \%$ потребителей не нуждаются в десятках и сотнях мегаватт мощности и, следовательно, не нуждаются в обязательном централизованном энергоснабжении, общие потери которого при транспортировке по сетям до потребителя составляют до 25...30\%. В этих условиях реальным путем повышения эффективности энергетического производства является развитие локальных автономных децентрализованных источников комбинированного производства электроэнергии и тепла на базе газопоршневых двигателей, неоспоримыми преимуществами которых являются высокий КПД, полная независимость от региональных энергосетей, а следовательно, и от роста тарифов, надежность, отсутствие затрат на строительство подводящих и распределительных сетей.

Газопоршневые установки (ГПУ) работают от двигателей внутреннего сгорания, топливом для которых служит газ. Фактически это аналог дизельгенераторных электростанций, которые можно переделать под данный вид топлива.

Электрический КПД газопоршневых установок достигает 40\%, что несколько выше, чем у ГТУ, а вот тепловой КПД ниже - 50\%. Меньшим является также потолок мощности, который составляет около 9 МВт.

В настоящее время многие производители проводят адаптацию своих двигателей под соответствующее топливо, что в большинстве случаев не занимает много времени и не требует больших финансовых затрат. Помимо природного газа, газопоршневые установки могут использовать в качестве топлива: пропан, бутан, попутный нефтяной газ, газы химической промышленности, коксовый газ, древесный газ, пиролизный газ, газ мусорных свалок, газ сточных вод и т. д. Применение в качестве топлива перечисленных специфических газов вносит важный вклад в сохранение окружающей среды и позволяет использовать регенеративные источники энергии. 


\section{СТАБИЛИЗАЦИЯ СВОЙСТВ ТОПЛИВНО-ЭНЕРГЕТИЧЕСКИХ СИСТЕМ НА ОСНОВЕ ПРИРОДНЫХ И СИНТЕТИЧЕСКИХ ПОЛИМЕРОВ}

Построение технологической схемы когенерационной установки (мини-ТЭЦ) направлено на максимально эффективное использование топлива. Когенерационный энергоблок состоит из двух газопоршневых установок на базе ДВС и системы утилизации теплоты охлаждающей жидкости и выхлопных газов двигателей. $\mathrm{B}$ некоторых случаях возможно и целесообразно использование когенерационных установок в режиме одновременного производства трех видов энергии: электроэнергии, теплоты и холода.

Это дает возможность эффективно использовать в летний период утилизируемую теплоту, что особенно важно для многих промышленных предприятий и учреждений, где летняя потребность в отоплении помещений и нагреве воды на горячее водоснабжение может быть незначительной. Применение в когенерационных системах абсорбционных машин, преобразовывающих тепловую энергию в холод, позволяет рационально использовать установки и значительно повысить их экономическую эффективность, кроме того, мини-ТЭС на базе когенерационных установок имеют экологические преимущества.

При выборе первичного двигателя и в целом КГУ обращают внимание на несколько факторов:

- вид топлива, используемый в установке;

- необходимая мощность, какое количество электроэнергии и теплоты необходимо произвести.

У каждого типа двигателя имеются свои особенности (при сгорании топлива), которые влияют на конечный выбор всей когенерационной установки (станции).

Поршневой двигатель (ДВС) рассчитан на работу на различных составах топлива, в том числе на биогазе. Достоинством этих установок является возможность их лучшего использования на относительно малых мощностях. Применяют два типа поршневых двигателей: с искровым зажиганием, работающих на чистом газе, природном газе, биогазе и других; 


\section{СТАБИЛИЗАЦИЯ СВОЙСТВ ТОПЛИВНО-ЭНЕРГЕТИЧЕСКИХ СИСТЕМ НА ОСНОВЕ ПРИРОДНЫХ И СИНТЕТИЧЕСКИХ ПОЛИМЕРОВ}

воспламенением от сжатия, которые могут работать на дизельном топливе или природном газе (с добавлением 5\% дизельного топлива для обеспечения воспламенения топливной смеси).

Единичные мощности поршневых машин лежат в пределах от 0,2 до 20 МВт для дизелей и от 3 кВт до 6 МВт для искровых двигателей. Для них характерны следующие весомые достоинства:

- высокая производительность;

- эффективная работа в широком спектре нагрузок (от 30 до 100\%);

- многообразие моделей по выходной мощности;

- гибкость в выборе топлива и возможность работы на нескольких его видах;

- преобладание производства электроэнергии;

- имеется возможность использования теплоты от охлаждения элементов машины.

Оценка показателей энергоэффективности когенерационных установок определяется расчетным путем по методике, учитывающей структуру энергобаланса и соотношения используемых теплоперепадов в комбинированном цикле на генерацию электрической и тепловой энергии.

Газопоршневые электростанции могут иметь открытое исполнение для установки в помещениях и контейнерное исполнение для установки на открытой площадке. На базе единичных агрегатов выстраиваются параллельные системы (2-6 агрегатов) необходимой мощностью. Использование газового топлива для энергетических установок позволяет снизить стоимость электроэнергии и получить сопутствующую генерацию тепловой энергии. Общий КПД когенерационных установок достигает 82\%.

В разработанной модульной установке КГУ переработки твердых целлюлозосодержащих отходов отходы собираются в специальном накопителе, где происходит их временное хранение и подготовка к утилизации (рис. 4.25). 


\section{СТАБИЛИЗАЦИЯ СВОЙСТВ ТОПЛИВНО-ЭНЕРГЕТИЧЕСКИХ СИСТЕМ НА ОСНОВЕ ПРИРОДНЫХ И СИНТЕТИЧЕСКИХ ПОЛИМЕРОВ}

В накопителе из отходов приготавливается исходная биомасса - субстрат. Для этого отходы подвергаются измельчению крупных частей. Затем полученный субстрат подается в ферментер через промежуточную емкость гомогенизатор.

Для ускорения процесса ферментации субстрата вводят препарат (на основе Тамира) и поддерживается оптимальная температура (технология ферментации представлена в п.4.2).

После завершения процесса ферментации производят выгрузку гумуса в накопительный резервуар, техническое обслуживание ферментера и ферментер заполняют новой порцией субстрата, далее процесс повторяется.

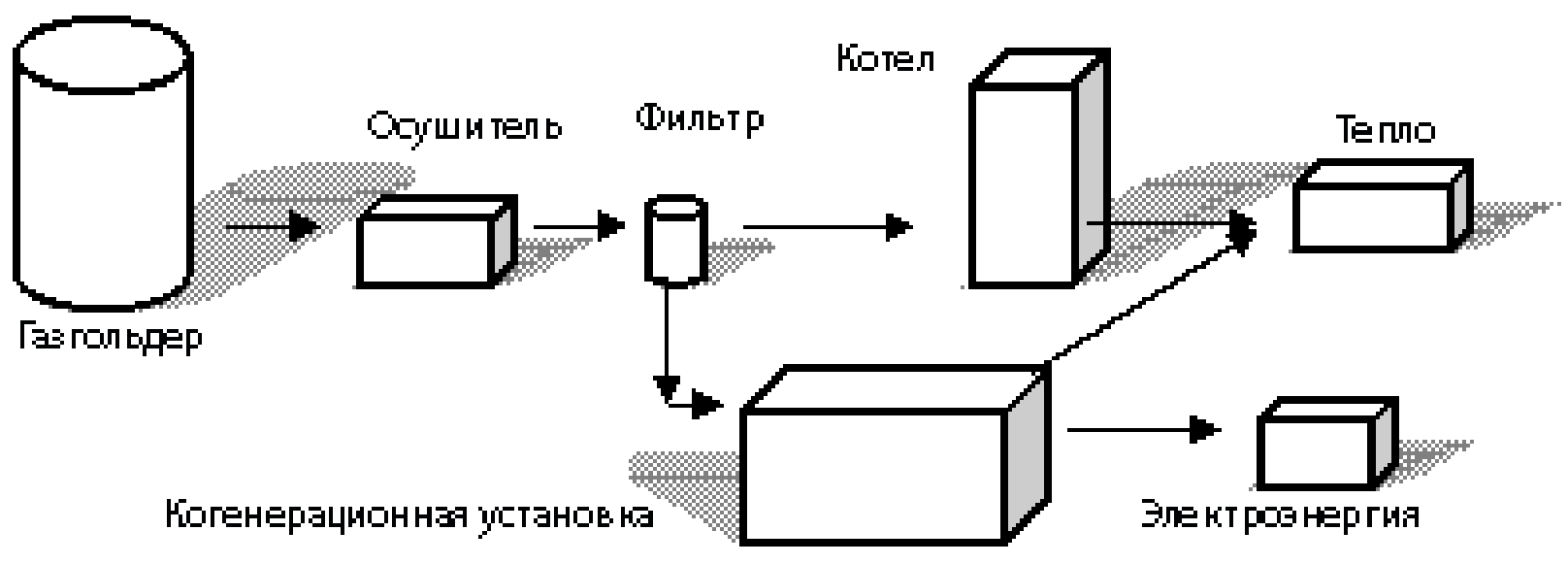

Рис. 4.25. Схема использования биогаза в качестве нетрадиционного вида топлива

Выделяющийся из субстрата биогаз собирают в газгольдере. Биогаз поступает в газгольдер через систему удаления конденсата водных паров, углекислого газа. Очищенный биогаз поступает непосредственно в котлы для производства теплоты или в когенерационные установки для выработки электроэнергии. Так же биогаз может использоваться для производства холода на абсорбционных или комбинированных холодильных машинах

Когенерационный блок работает с резервной линии подачи электроэнергии из общей сети, на случай перебоев в подаче биогаза (рис. 4.26). 
Все это позволяет достичь максимальной эффективности и бесперебойности электроснабжения объекта.

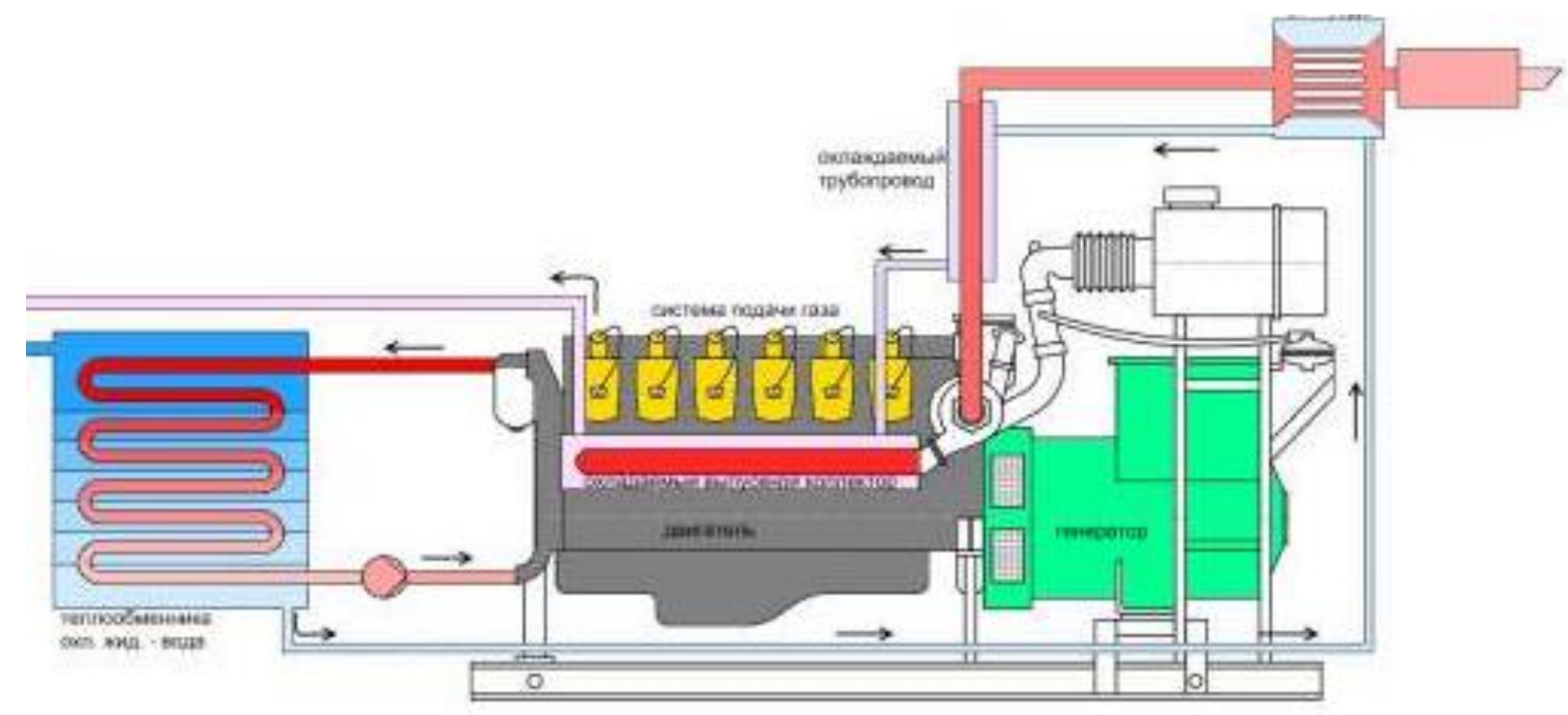

Рис. 4.26. Принципиальная схема работы когенерационной установки

При использовании биогаза в качестве топлива возникает ряд технических задач, связанных с его составом и физико-химическими свойствами (табл. 4.4, 4.5). По сравнению с другими газами, биогазу нужно меньше воздуха для возгорания. Следовательно, обычные газовые горелки и приборы нуждаются в более широких жиклерах для прохождения биогаза. Для полного сгорания 1 литра биогаза необходимо около 5,7литра воздуха, в то время как для бутана - 30,9 литра и для пропана - 23,8 литра.

По отношению к наиболее распространенным горелкам, приспособленным для использования бутана и пропана, можно отметить, что бутан и пропан обладают теплотворной способностью почти в 3 раза выше, чем биогаз, и даёт в два раза большее пламя. Перевод горелок на работу на биогазе всегда приводит к более низким уровням работы приборов. Некоторые практические меры для модификации горелок включают: увеличение жиклеров в $2 \ldots 4$ раза для прохождения газа, изменение объема подачи воздуха. 
Таблица 4.4

Физико-химические свойства биогаза

\begin{tabular}{|l|c|c|c|c|c|c|}
\hline \multirow{2}{*}{ Характеристики } & \multicolumn{5}{|c|}{ Компоненты биогаза } & \multirow{2}{*}{ Биогаз } \\
\cline { 2 - 6 } & $\mathrm{CH}_{4}$ & $\mathrm{CO}_{2}$ & $\mathrm{H}_{2}$ & $\mathrm{H}_{2} \mathrm{~S}$ & $\mathrm{~N}_{2}$ & \\
\hline Объемная доля, \% & $55-70$ & $20-44$ & 1 & 1 & $<3$ & 100 \\
\hline $\begin{array}{l}\text { Объемная теплота } \\
\text { сгорания, МДж/ м }\end{array}$ & 35,8 & - & 10,8 & 22,8 & - & 21,5 \\
\hline $\begin{array}{l}\text { Предел воспламеняемости } \\
\text { (содержание в воздухе, \%) }\end{array}$ & $5-15$ & - & $4-30$ & $4-45$ & - & $5-12$ \\
\hline $\begin{array}{l}\text { Температура } \\
\text { воспламенения }\end{array}$ & 650 & - & 585 & - & - & $650-750$ \\
\hline Нормальная плотность, г/л & 0,72 & 1,98 & 0,9 & 1,554 & - & 1,2 \\
\hline Состав биогаз: $\mathrm{CH}_{4}-60 \%, \mathrm{CO}_{2}-40 \%$ \\
\hline
\end{tabular}

Для успешной работы КГУ двигатель адаптируют под соответствующее топливо - биогаз, по теплоте сгорания, степени детонации и метановому числу. В состав модуля КГУ входят генераторы постоянного и переменного тока, водогрейные котлы, системы охлаждения, управления, вентиляции, сигнализации, смазки. Модуль дополнительно оборудуется системами кондиционирования (рис. 4.26).

Таблица 4.5

Состав биогаза

\begin{tabular}{|l|c|c|}
\hline \multicolumn{1}{|c|}{ Составляющие } & Природный газ & Биогаз \\
\hline Метан, \% & $85-95$ & $55-80$ \\
\hline Углекислород, \% & $<1,0$ & $20-45$ \\
\hline Азот, $\%$ & $4-12$ & - \\
\hline Кислород, \% & $<0,5$ & - \\
\hline Водород, \% & - & $<1,0$ \\
\hline Сероводород, мг $/ \mathrm{M}^{3}$ & $50-100$ & $500-5000$ \\
\hline Калорийность, МДж/м ${ }^{3}$ & $32-35$ & $29-29$ \\
\hline
\end{tabular}


Для построения когенерационного модуля в качестве наиболее перспективного агрегата используется газопоршневая установка, на базе двигателей ЯМЗ и ТМЗ Газопоршневая установка относится к установкам с относительно простой системой обслуживания и управления, низкой стоимости и высоким показателем полного КПД (сумма электрического и теплового КПД).

Биогазовая установка имеет четыре источника прибыли:

- выработка электроэнергии,

- выработка тепловой энергии,

- производство гумуса

- и обезвреживания отходов.

Предлагаемая схема тепло- и электроснабжения наиболее эффективно может быть использована для различных сельскохозяйственных объектов, в том числе для энергоснабжения теплиц.

Применение предлагаемой схемы позволит решить экологические проблемы сжигания топлива, повысить эффективность производства за счет получения и использования биогумуса и биогаза.

На основании вышесказанного можно сделать вывод, что малая энергетика успешно дополняет централизованную систему энергоснабжения и во многих случаях способна решить проблему надежного и экономичного обеспечения тепловой и электрической энергией промышленных и жилищнокоммунальных объектов. 


\section{ГЛАВА 5.}

\section{ТЕОРЕТИЧЕСКИЕ АСПЕКТЫ РЕКУЛЬТИВАЦИИ ТЕХНОГЕННЫХ ПОЧВ}

\section{1 Почва как возобновляемый природный ресурс}

\subsection{1 Структура, состав и свойства почв}

Почва - особое природное образование, возникшее в результате преобразования поверхностных слоев литосферы под совместным воздействием воды, воздуха, климатических факторов и живых организмов в условиях гравитационного поля Земли. Почвы обеспечивают стабильные показатели качества природных экосистем: видовое разнообразие, потоки биогенных веществ энергии. Устойчивость почв к антропогенному давлению определяют ее физико-химические свойства: буферная емкость, механический состав, водно-солевой режим, реакции окисления и восстановления, тип почв, содержание гумуса, биологическая активность.

Почва, как среда жизни, характеризуется как трехфазная сфера (рис. 5.1), состоящая из жидкой (почвенный раствор, вода), газообразной (почвенный воздух), твердой (гумус, минералы) фаз [5, с. 88]. 

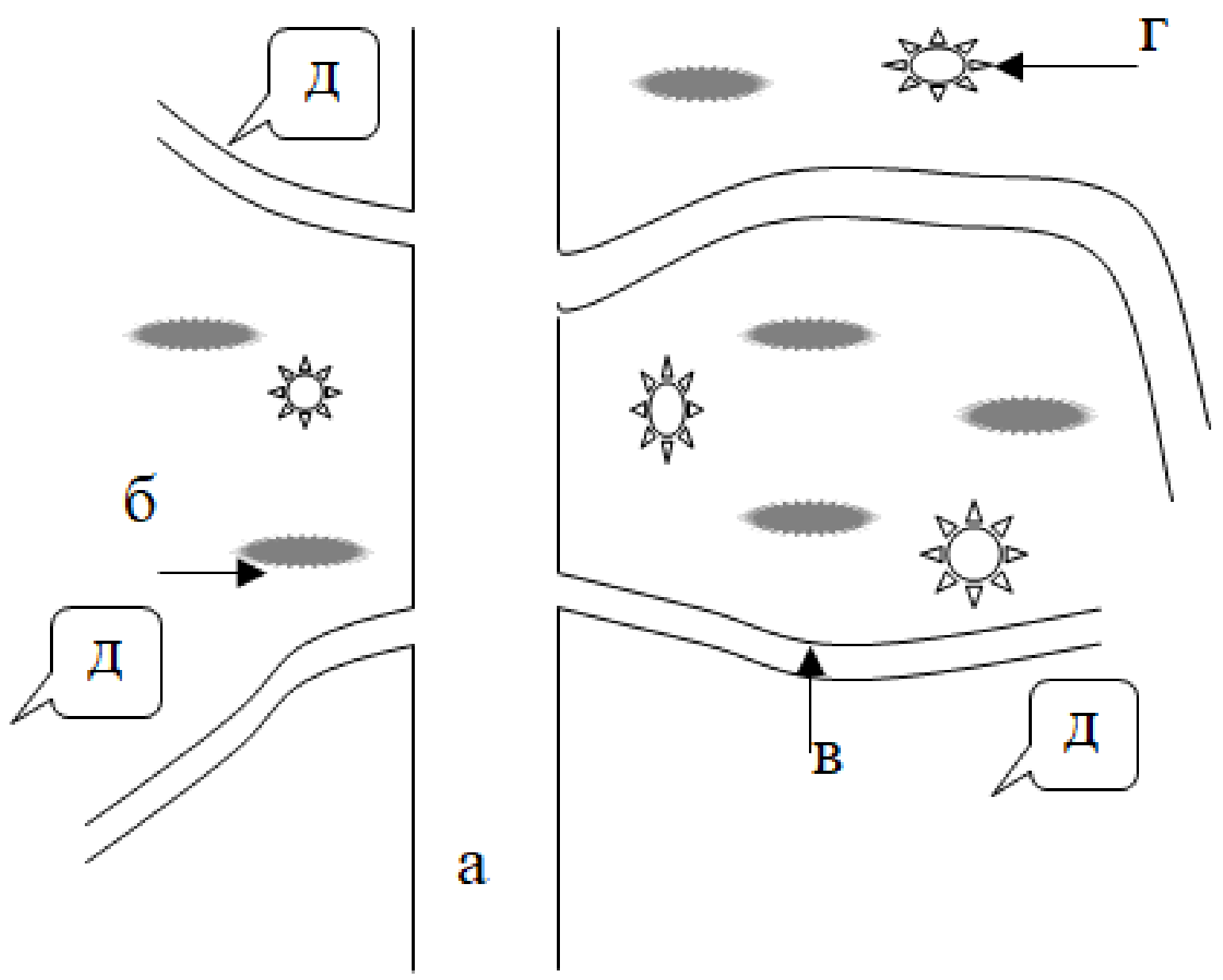

Рис. 5.1. Структура почвы

a - корень, б - частицы почвы, в - корневой волосок, г - влага, д- пузырьки воздуха

Твердые фаза почвы пронизаны порами и полостями, заполненными частично водой и растворенными в ней минеральными солями, частично воздухом. Пористость - важная характеристика почв и сотавляет до 70 \% для рыхлой и $20 \%$ - для плотной почвы. В полостях или на поверхности твердых частиц обитает огромное количество микроскопических организмов: бактерий, грибов, простейших, круглых червей, членистоногих. Более крупные животные (черви, медведка) прокладывают ходы в почве сами. Вся почва пронизана корнями растений. Глубина почвы определяется глубиной проникновения корней и деятельностью роющих животных, от 1,5 ... 2 м. 


\section{СТАБИЛИЗАЦИЯ СВОЙСТВ ТОПЛИВНО-ЭНЕРГЕТИЧЕСКИХ СИСТЕМ НА ОСНОВЕ ПРИРОДНЫХ И СИНТЕТИЧЕСКИХ ПОЛИМЕРОВ}

Воздух в почвенных полостях всегда насыщен водяными парами, обогащен диоксидом углерода $\mathrm{CO}_{2}$ и обеднен кислородом. Главная особенность почвенной среды - постоянное поступление органических веществ, в основном за счет мертвого вещества (детрита), отмирающих корней растений и опадающей листвы.

Почвенно-биотический комплекс связывает живое и неживое вещество биосферы в единую систему - «биокостное тело» (В.И. Вернадский). Элементарный химический состав поверхностного слоя почвы соответствует химическому составу земной коры литосферы (рис. 5.2), который выражают содержанием оксидов: кремния $\left(\mathrm{SiO}_{2}\right)$, алюминия $\left(\mathrm{Al}_{2} \mathrm{O}_{3}\right)$, железа $\left(\mathrm{Fe}_{2} \mathrm{O}_{3}\right)$, кальция $(\mathrm{CaO})$, магния $(\mathrm{MgO})$, калия $\left(\mathrm{K}_{2} \mathrm{O}\right)$, натрия $\left(\mathrm{Na}_{2} \mathrm{O}\right)$.

Минеральная часть составляет $80 \ldots 90 \%$ массы почв и содержит макроэлементы: кислород (O), кремний $(\mathrm{Si})$, алюминий $(\mathrm{Al})$, железо $(\mathrm{Fe})$, кальций $(\mathrm{Ca})$, магний $(\mathrm{Mg})$ калий $(\mathrm{K})$, натрий $(\mathrm{Na})$ и микроэлементы: бор (B), марганец $(\mathrm{Mn})$, медь $(\mathrm{Cu})$, цинк $(\mathrm{Zn})$, молибден $(\mathrm{Mo})$ и другие. Химический состав влияет на питательный режим растений и плодородие почв. На образование 10 см слоя плодородной почвы с содержанием гумуса до $5 \%$ необходимо 100 лет. В составе почвы содержание углерода примерно в 20 раз больше, а азота - в 10 раз больше по сравнению с их содержанием в земной коре литосферы.

Твердая фаза почвы - почвенный поглощающих комплекс (ППК), способна к реакциям ионного обмена и представлена системой коллоидов и высокодисперсных веществ, состав которых зависит от гранулометрического состава и содержания гумуса. ППК регулирует буферные свойства и поддерживает стабильность кислотно-щелочного баланса почв:

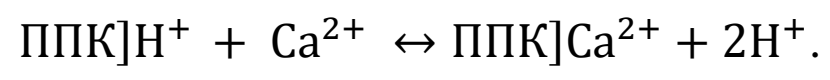


Живое вещество биосферы

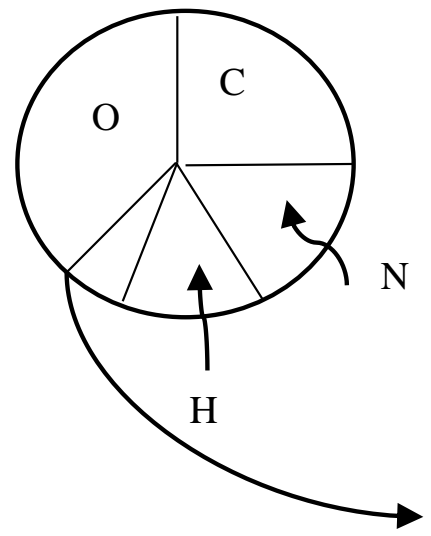

Земная кора литосферы

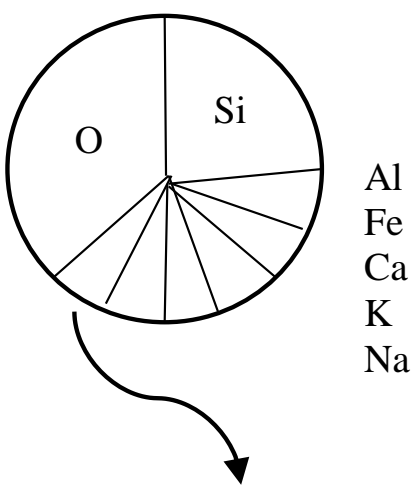

Остальные элементы
Поверхностный слой почвы

$\mathrm{O}$

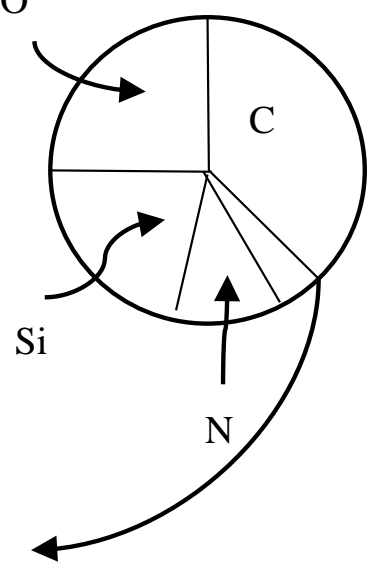

Рис. 5.2. Химический состав живого вещества, земной коры литосферы и поверхностного слоя почвы

В свою очередь насыщенность почвенных коллоидов катионами кальция $\mathrm{Ca}^{++}$повышает биологическую активность почв, улучшает их физические свойства и питательный режим. По размеру частиц дисперсной фазы коллоидные системы делят на грубодисперсные и высокодисперсные системы. Грубодисперсные системы - суспензии, эмульсии, порошки с размером частиц не меньше 1 мкм или $10^{-2} \ldots 0^{-6} \mathrm{~cm}$. Высокодисперсные системы (или коллоидные системы) - мембраны, золи, гели, студни, размеры которых не больше 1 мкм (1,0 мкм .. 1,0 нм) или находят в интервале $10^{-7} \ldots 10^{-9} \mathrm{~cm}$.

Количество почвенных коллоидов не превышает $30 \ldots 40 \%$ от почвенной массы. Среди минеральных солей наибольшей подвижностью обладают нитрат ионы $\left(\mathrm{NO}_{3}^{-}\right)$, образующиеся при диссоциации азотной кислоты $\left(\mathrm{HNO}_{3}\right)$ и ее солей - нитрата калия $\left(\mathrm{KNO}_{3}\right)$ или натрия $\left(\mathrm{NaNO}_{3}\right)$. Большинство питательных элементов поступают в растения через корневую систему, хотя некоторые могут абсорбироваться устьицами листьев. 


\section{СТАБИЛИЗАЦИЯ СВОЙСТВ ТОПЛИВНО-ЭНЕРГЕТИЧЕСКИХ СИСТЕМ НА ОСНОВЕ ПРИРОДНЫХ И СИНТЕТИЧЕСКИХ ПОЛИМЕРОВ}

В состав почвы входят кроме минеральных веществ органические и органоминеральные вещества. Органическое вещество почв представлено органическими остатками живых организмов, продуктами их метаболизма, а также специфическими органическими соединениями - гумусом [102, с. 64]. Неспецифические органические соединения - производные живого вещества биосферы, поступают в почву в виде мертвого вещества (детрита) фитоценозов, зооценозов, микроорганизмов, которые под действием ферментов микроорганизмов подвергаются деструкции до углеводов, белков, липидов, лигнина (табл. 5.1), восков, дубильных веществ, фенолов и других веществ.

Таблица 5.1

\section{Элементарный состав органической части почвы}

\begin{tabular}{|l|c|c|c|c|}
\hline \multirow{2}{*}{\multicolumn{1}{c|}{ Полимеры }} & \multicolumn{4}{|c|}{ Элементарный состав, } \\
& \multicolumn{2}{c|}{ \% (на сухую беззольную массу) } \\
\cline { 1 - 5 } & $\mathrm{C}$ & $\mathrm{H}$ & $\mathrm{O}$ & $\mathrm{N}$ \\
\hline Углеводы & $40 \ldots 45$ & 6,0 & $49 \ldots 54$ & - \\
\hline Белки & $50 \ldots 53$ & $6,0 \ldots 7,0$ & $19 \ldots 24$ & $16 \ldots 18$ \\
\hline Липиды & $76 \ldots 79$ & $11 \ldots 13$ & $10 \ldots 12$ & - \\
\hline Фульвокислоты & $41 \ldots 49$ & $4,0 \ldots 5,0$ & $47 \ldots .52$ & $2,0 \ldots 5,0$ \\
\hline Гуминовые кислоты & $52 \ldots 62$ & $3,0 \ldots 6,0$ & $31 \ldots 39$ & $2,0 \ldots 5,0$ \\
\hline Лигнин & $60 \ldots 66$ & 6,0 & $28 \ldots 34$ & 1,0 \\
\hline
\end{tabular}

Гумусовые вещества - консервант солнечной энергии, которая была накоплена в процессе фотосинтеза зелеными растениями и трансформирована в гумус. Именно поэтому почву относят к возобновляемым природным ресурсам.

Специфические органические (гумусовые) вещества - фульвокислоты и гуминовые кислоты и их соотношение в почве, определяет качество почв (миграцию и аккумуляцию биогенных элементов или токсичных веществ). Изменение этого соотношения свидетельствует о влиянии техногенных факторов на деградацию почв. 


\subsection{2 Почвообразовательные факторы}

Почвообразовательный процесс связан с формированием генетически связанных горизонтов, возникающих в результате преобразования поверхностных слоев литосферы под совместным воздействием экологических факторов (абиогенных, биогенных, антропогенных). Биогенное воздействие определяется круговоротом биогенных элементов: азота (N), углерода (C), фосфора (P), серы (S) веществ, в результате которого они из связанного состояния переходят в подвижное состояние [5, с. 159]. Действие абиогенных факторов регулирует поток солнечной энергии. Солнечная энергия обеспечивает тепловой режим поверхности биосферы, процессы ионизации атомов, диссоциации молекулярных газов атмосферы, фотосинтез. Солнечная энергия использованная и трансформированная в биохимические связи биологически активных веществ растений передается по звеньям пищевой цепи

$$
\text { растения } \rightarrow \text { животные } \rightarrow \text { микроорганизмы }
$$

с потерей на каждом этапе в виде тепла. Под действием ферментов желудочно-кишечного тракта травоядных животных растительный белок трансформируется в новые формы - животный белок. Остатки растений, животных и микроорганизмов - детрит попадая в почву при благоприятных климатических условиях минерализуются до подвижных форм биогенных элементов и возвращаются в круговорот веществ или остаются в связанном виде в гумусе. Наиболее эффективно протекает круговорот азота (рис. 5.3) и углерода (рис. 5.4).

Азот входит в состав атмосферного воздуха в виде свободных молекул азота $\left(\mathrm{N}_{2}\right)$. Другие газообразные формы азота попадают в приземный слой атмосферы, в результате круговорота вещества биосферы окисляются кислородом до ионов $\mathrm{NO}_{3}$, соединяются с конденсированными молекулами воды, формируют облака, которые переносятся воздушными потоками, и при 


\section{СТАБИЛИЗАЦИЯ СВОЙСТВ ТОПЛИВНО-ЭНЕРГЕТИЧЕСКИХ СИСТЕМ НА ОСНОВЕ ПРИРОДНЫХ И СИНТЕТИЧЕСКИХ ПОЛИМЕРОВ}

благоприятных климатических условиях выпадают из атмосферы с осадками в виде кислотных дождей в гидросферу и литосферу.

Азот в аммонийной форме $\mathrm{NH}_{3}$ попадает в атмосферный воздух при грозовых разрядах; в форме оксидов $\mathrm{NO}, \mathrm{NO}_{2}, \mathrm{~N}_{2} \mathrm{O}$ при горении лесов и вулканической деятельности, а также при сгорании твёрдого и жидкого топлива в виде техногенных выбросов. Молекулярная форма азота $\left(\mathrm{N}_{2}\right)$ участвует в реакции транспирации обратной реакции фотосинтеза - дыхании живых организмов: растений, животных, микроорганизмов.

В литосфере основная масса азота находится в связанном состоянии гумуса, торфа, каменного угля, нефти. Подвижные формы минерального азота $\mathrm{NH}_{4}{ }^{+}, \mathrm{NO}_{3}^{-}$, находятся в почвенном растворе и используются растениями в качестве питания для роста растений; участвуют в биосинтезе растительного белка и нуклеиновых кислот, хлорофилла, а часть вымывается в грунтовые воды.

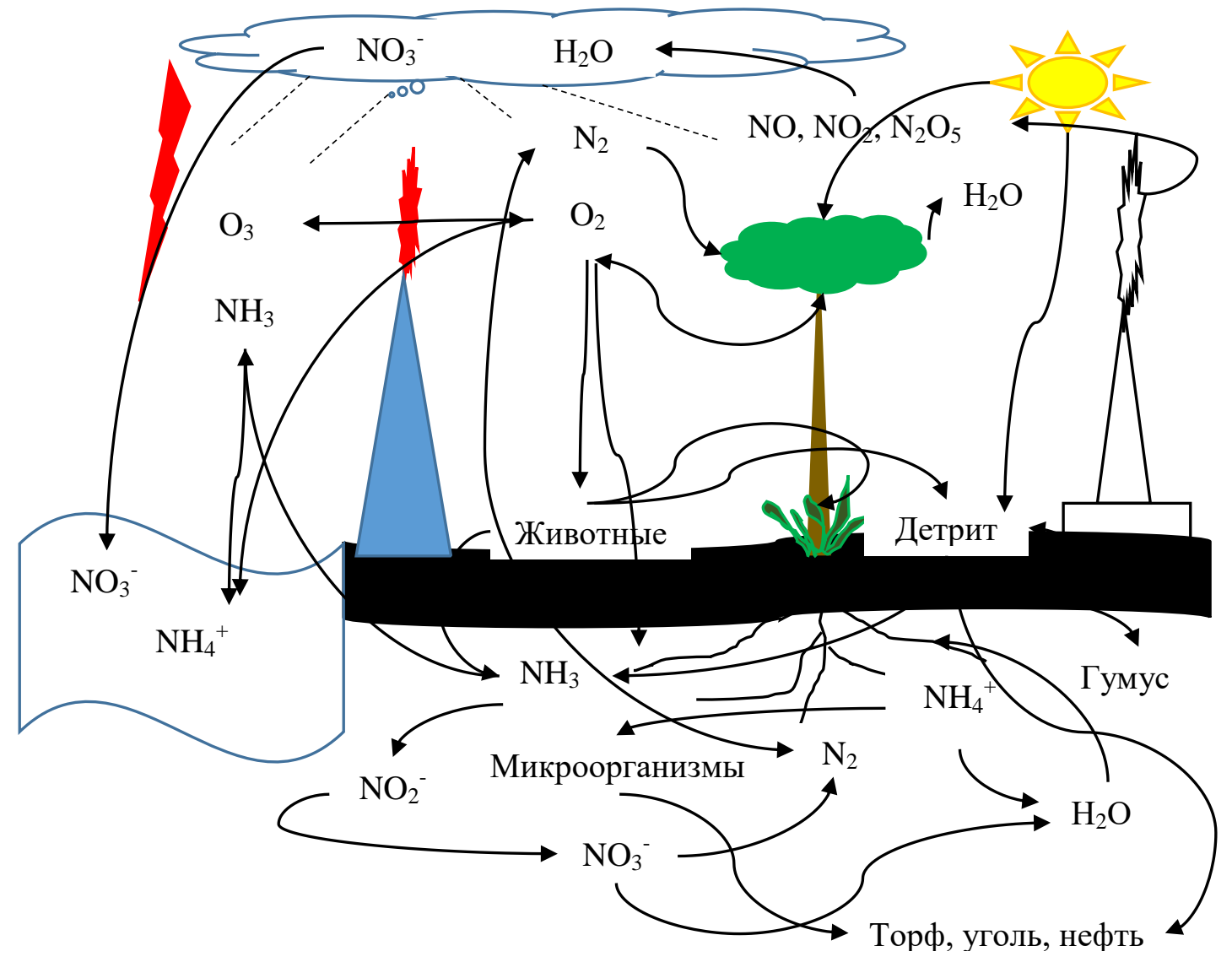

Рис. 5.3. Круговорот азота в природной экосистеме 


\section{СТАБИЛИЗАЦИЯ СВОЙСТВ ТОПЛИВНО-ЭНЕРГЕТИЧЕСКИХ СИСТЕМ НА ОСНОВЕ ПРИРОДНЫХ И СИНТЕТИЧЕСКИХ ПОЛИМЕРОВ}

Под действием ферментов микроорганизмов почвы трансформируется в реакциях

$$
\text { нитрификации } \quad \mathrm{NH}_{3} \rightarrow \mathrm{HNO}_{2} \rightarrow \mathrm{HNO}_{3},
$$

аммонификации

растительный белок $\rightarrow$ аминокислоты $\rightarrow \mathrm{NH}_{3}$, денитрификации: $\mathrm{HNO}_{3} \rightarrow \mathrm{N}_{2}$.

Углерод (C), также как азот входит в состав атмосферного воздуха в виде диоксида углерода $\left(\mathrm{CO}_{2}\right)$ и в состав живого вещества (белки, липиды, углеводы) биосферы - растений, животных, микроорганизмов.

Энергия солнца передается по пищевой цепи:

$$
\text { растения } \rightarrow \text { животные } \rightarrow \text { микроорганизмы. }
$$

Растения используют атмосферный $\mathrm{CO}_{2}$, воду. Квант (hv) солнечной энергии в процессе фотосинтеза используется в количестве $1 . .5 \%$ падающего светового потока, аккумулируется в биохимических связях органических соединений углеводов (глюкозы) с выделением кислорода

$$
\mathrm{CO}_{2} \uparrow+\mathrm{H}_{2} \mathrm{O} \leftrightarrow \mathrm{C}_{6} \mathrm{H}_{12} \mathrm{O}_{6}+\mathrm{O}_{2} \uparrow,
$$

необходимого для дыхания всех живых организмов (рис. 5.4).

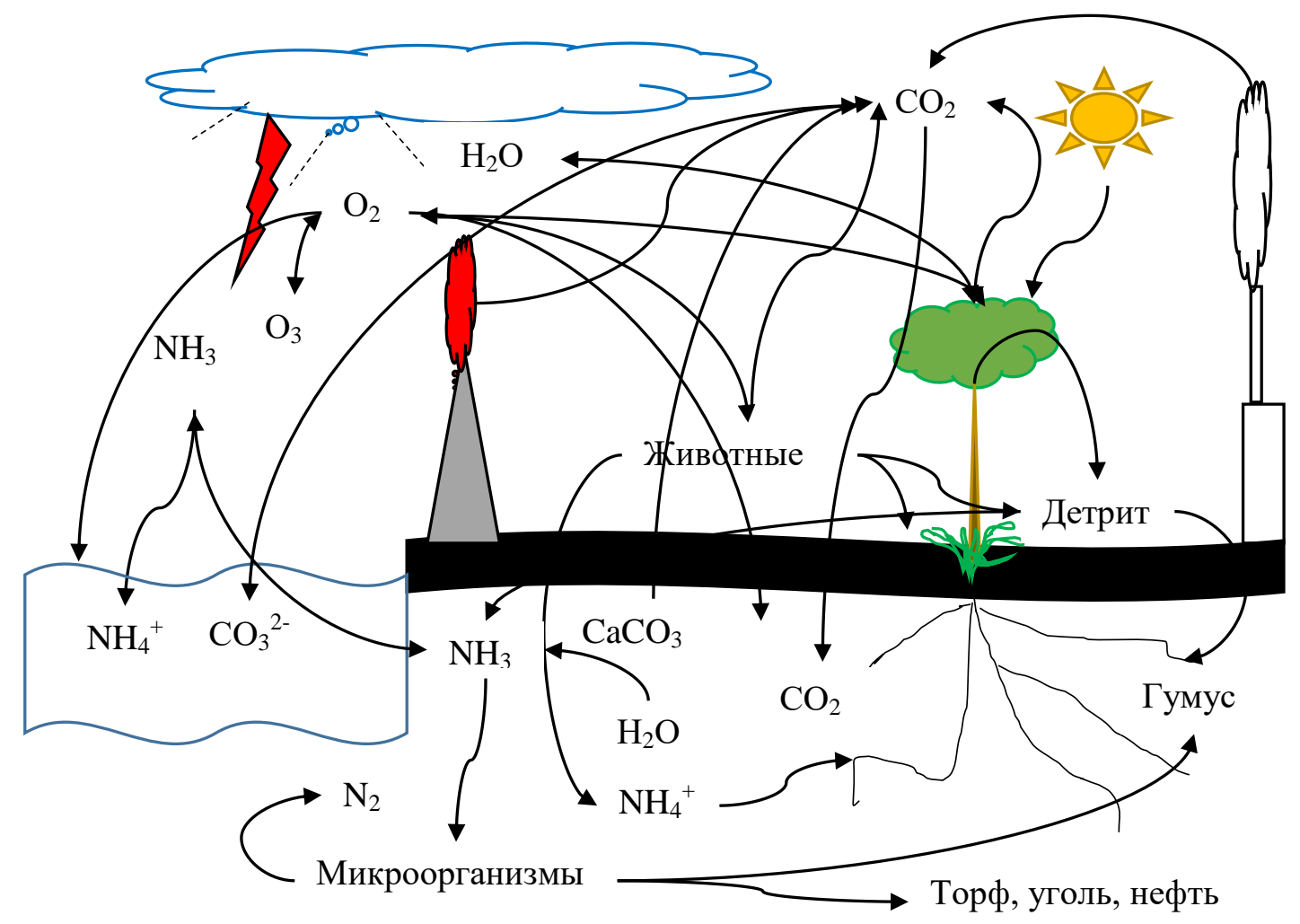

Рис. 5.4. Круговорот углерода в природной экосистеме 


\section{СТАБИЛИЗАЦИЯ СВОЙСТВ ТОПЛИВНО-ЭНЕРГЕТИЧЕСКИХ СИСТЕМ НА ОСНОВЕ ПРИРОДНЫХ И СИНТЕТИЧЕСКИХ ПОЛИМЕРОВ}

Атмосфера обменивается веществом с космосом: космическая пыль, метеоритный материал, легкие инертные газы.

Постоянным компонентом атмосферы является вода в разных формах, кислород $\left(\mathrm{O}_{2}\right)-20,9 \%$, азот $\left(\mathrm{N}_{2}\right)-78,1 \%$, инертные газы - $1 \%$, диоксид углерода $\left(\mathrm{CO}_{2}\right)-0,03 \%$, озон. Наибольшая плотность озона встречается в верхних слоях атмосферы на высоте приблизительно 20 км, который поглощая ультрафиолетовую радиацию, разлагается на молекулярный и атомный кислород. Способность озона задерживать губительные для живого вещества биосферы ультрафиолетовые лучи Солнца объясняется структурными особенностями его молекулы

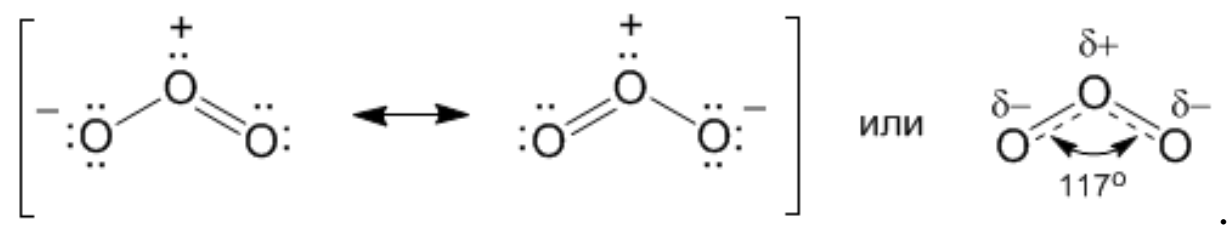

Молекула кислорода имеет линейную структуру: $\mathrm{O}=\mathrm{O}$. В зависимости от климатических факторов динамическое равновесие

$$
\mathrm{O}_{3} \leftrightarrow \mathrm{O}_{2}+\mathrm{O}
$$

смещается в сторону озона (грозовые разряды) или кислорода. Концентрация озона у земной поверхности составляет 6 .. 10\%.

Изменение концентрации $\mathrm{CO}_{2}$ в атмосферном воздухе зависит от климатических условий: ветра, рельефа земной поверхности; интенсивности дыхания живых организмов, прозрачности атмосферы, природных (пожары, вулканы) и техногенных (автомобильный транспорт, промышленные предприятия) экстремально-залповых выбросов. При дыхании всех живых организмов в атмосферный воздух выделяется $\mathrm{CO}_{2}$. В атмосферный воздух углекислый газ попадает при реакциях горения лесов, вулканической деятельности, брожения, гниения - естественный путь; при переработке твердого и жидкого топлива, работе двигателей внутреннего сгорания техногенный. Органическое вещество, синтезируемое растениями, передаётся через пищевые цепи и преобразуется в новую форму. Часть веществ 
растительного и животного происхождения, не вовлекаемое в круговорот веществ, накапливается и превращается в биогенное вещество (торф, нефть, каменный уголь). Мертвое вещество в почве, воде под действием микроорганизмов разлагается до минеральной формы, которая вновь вовлекается в круговорот веществ (брожение, гниение).

Аккумуляция химических веществ в почвенно-биотическом комплексе влияет на окислительные или восстановительные процессы гумификации почв $\left(\mathrm{Fe}^{2+} \leftrightarrow \mathrm{Fe}^{3+}\right)$. Гумификация почв зависит от экологических факторов (абиогенных, биогенных, антропогенных), скорости поступления биомассы растительного и животного происхождения, аэрации и влажности почв, гранулометрического состава, буферной емкости, биологической активности почв и скорости деструкции неспецифических органических веществ.

Интегральную диагностику стабильности качества системы почвафитоценоз проводят по биологической активности почв, содержанию азотфиксирующих, нитрифицирующих микроорганизмов или по активности их ферментов, катализирующих гумификацию почв с образованием гумуса. По суммарной активности почвенных организмов, разлагающих органическое вещество и выделяющих диоксид углерода (дыхание почвы). Дыхание почвы динамичный процесс и меняется не только по сезонам года, но и в течение суток (суточная динамика), а также с изменением погодных условий. При угнетении почвенных микроорганизмов снижается физиологическая активность растений.

\subsection{3 Факторы гумификации почв}

Гумификация - биохимический процесс превращения продуктов распада органических веществ в гумусовые вещества [103, с.10]. Гумусовые вещества высокомолекулярные соединения, обладающие высокой физиологической активностью (стимулирующие рост корней). В их состав входят: азотсодержащие гумусовые кислоты - гуминовые, фульвокислоты (оксикарбоновые), 190 
гиматомелановые, гумины - полимерная система, состоящая из лигнина, белка, целлюлозы, гемицеллюлозы, пектина, липидов, смол, воска (рис. 5.5).

В основе теории гумификации почв лежат труды В.В. Докучаева, П.А. Костычева, И.В. Тюрина, М.М Кононовой, С.А. Ваксмана, Л.Н. Александровой, Д.С. Орлова и других исследователей. Главные продукты гумификации представлены гуминовыми и фульвокислотами, которые имеют переменный состав и определяют цвет (бурый, черный, серый) почв. В общем виде процесс гумификации почв можно представить в виде динамического равновесия химических и биохимических реакций деструкции неспецифических органических веществ и их биосинтезом. Согласно кинетической теории Д.С. Орлова процесс гумификации можно выразить в виде уравнения

$$
\mathrm{H}=f(\mathrm{Q}, \mathrm{I}, \mathrm{t}),
$$

где $\mathrm{H}$ - степень гумификации; Q - общий объем поступающих в почву растительных остатков; I - интенсивность их трансформации, зависящая от скоростей отдельных стадий процесса и пропорциональной биохимической активности почв; $\mathrm{t}$ - время воздействия почвы на поступившие остатки.

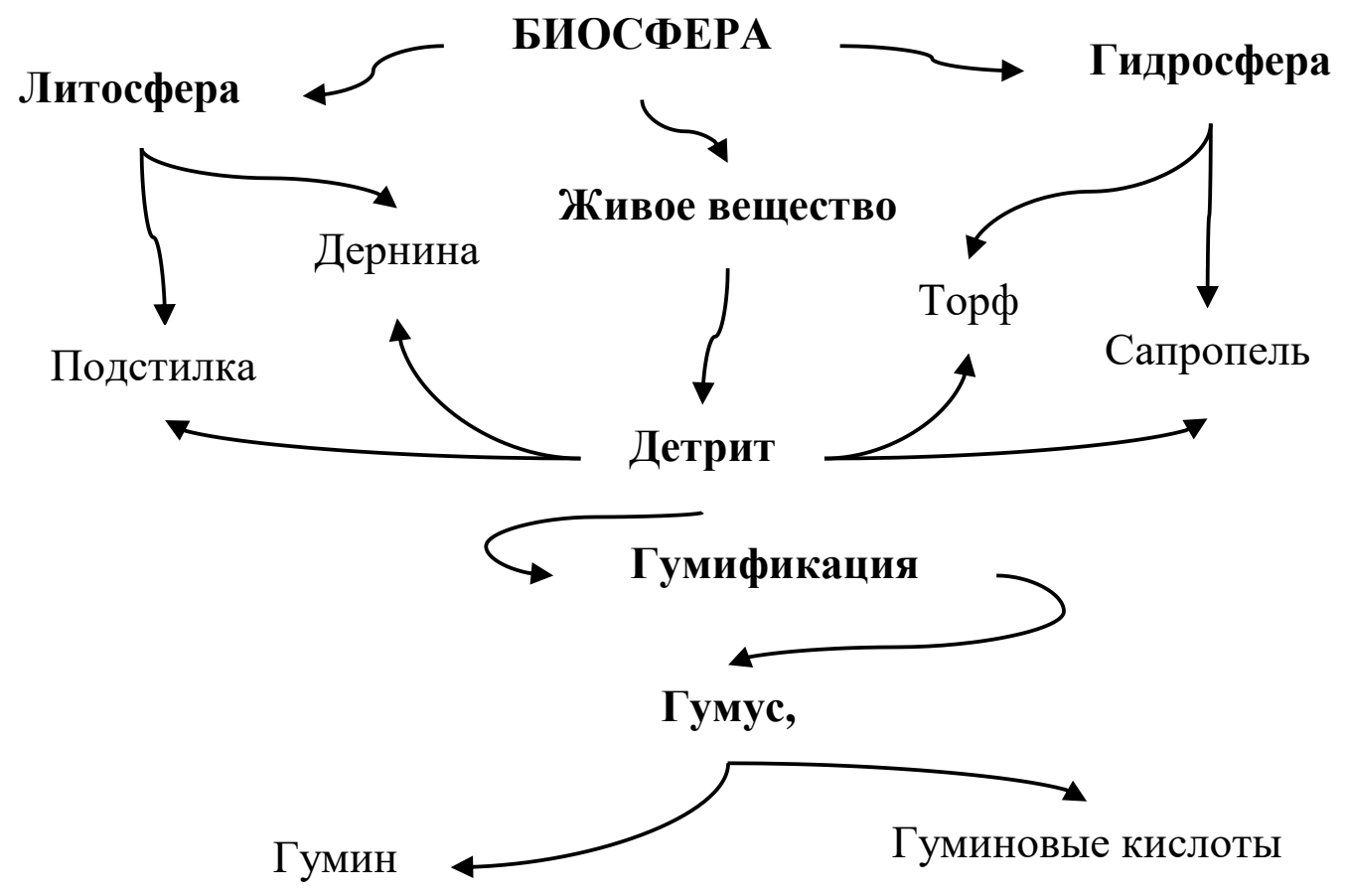

Рис. 5.5. Модель трансформации живого вещества в гумус почв 


\section{СТАБИЛИЗАЦИЯ СВОЙСТВ ТОПЛИВНО-ЭНЕРГЕТИЧЕСКИХ СИСТЕМ НА ОСНОВЕ ПРИРОДНЫХ И СИНТЕТИЧЕСКИХ ПОЛИМЕРОВ}

В естественных условиях в природных экосистемах гумификация отходов (детрита) протекает через ряд многократно повторяющихся биохимических реакций

$$
\text { биосинтез } \leftrightarrow \text { биоконверсия }
$$

c различной степенью полимеризации (или поликонденсации) и биоконверсии. Биоконверсия детрита начинается вне живых клеток под действием экзоферментов живого вещества и сводится к гидролизу макромолекул полимеров до олигомеров и мономеров, которые затем проникают через клеточные мембраны и подвергаются окислению под действием эндоферментов до минеральных соединений или низкомолекулярных органических соединений.

В этом процессе участвуют грибы, насекомые, земляные черви и бактерии. Биомасса микроорганизмов катализирует биосинтез, биоконверсию, адсорбцию и десорбцию биополимеров и минеральных веществ почвы. Главную роль в природном процессе гумификации углеводов играют грибы базидиомицеты, которые являются традиционными продуцентатами лигнинолитичеких ферментов (лакказы и пероксидазы). Разрушающие древесину базидиомицеты можно разделить на две группы. Возбудители бурой гнили превращают древесину в красновато-коричневую массу; они разрушают главным образом целлюлозные и гемицеллюлозные компоненты древесины и не действуют на фенилпропановые полимеры. Возбудители белой гнили разрушают древесину с образованием почти белой массы; они действуют в первую очередь на лигнин и почти не затрагивают целлюлозу. К грибам, разрушающим прежде всего лигнин, относятся Polystictus versicolor и некоторые другие (например, Stereum hirsutum). Есть также грибы, действующие одновременно на лигнин и целлюлозу; таковы Pleurotus ostreatus Ganoderma applanatum, Polyporus adustus, Armillaria mellea. Лигнин 


\section{СТАБИЛИЗАЦИЯ СВОЙСТВ ТОПЛИВНО-ЭНЕРГЕТИЧЕСКИХ СИСТЕМ НА ОСНОВЕ ПРИРОДНЫХ И СИНТЕТИЧЕСКИХ ПОЛИМЕРОВ}

травянистых растений практически не усваивается при пищеварения высших животных и поступает в почву в свободном активном состоянии с отходами. Лигнин отмерших растений под действием ферментов микроорганизмов через ряд промежуточных стадий гумифицируется в гумусовые кислоты и является одним из основных источников накопления углерода в органическом веществе почвы [71, с. 18; 104, с. 103; 105, с.10].

Полимеризационные гипотезы гумификации детрита опираются на концепцию окислительной полимеризации лигнина, содержащего фенольные метоксильные группы - $\mathrm{OCH}_{3}, \quad$ с азотсодержащими органическими веществами: нуклеиновыми или амино кислотами - продуктами биоконверсии белков и образования макромолекул гумусовых кислот.

Кислотообразование идет по типу

$$
\mathrm{C} \rightarrow \mathrm{COH} \rightarrow \mathrm{CHO} \rightarrow \mathrm{COOH} .
$$

Под действием абиотических факторов равновесный процесс биосинтез $\leftrightarrow$ биоконверсия сдвигается в сторону снижения скоростей реакций биосинтеза над скоростями реакций биоконверсии с образованием торфяников.

Процесс полимеризации гуминовых кислот из промежуточных структурных единиц - непрерывный и длительный. С течением времени в структуре макромолекул гуминовых кислот возрастает доля гетероциклической формы азота. При использовании графостатического метода Ван-Кревелена в работе [71, с. 37] были рассчитаны соотношения ароматической и алифатической фракций макромолекул гуминовых кислот (молодых) и предложена модель структуры макромолекул гуминовых кислот (рис. 5.7). 


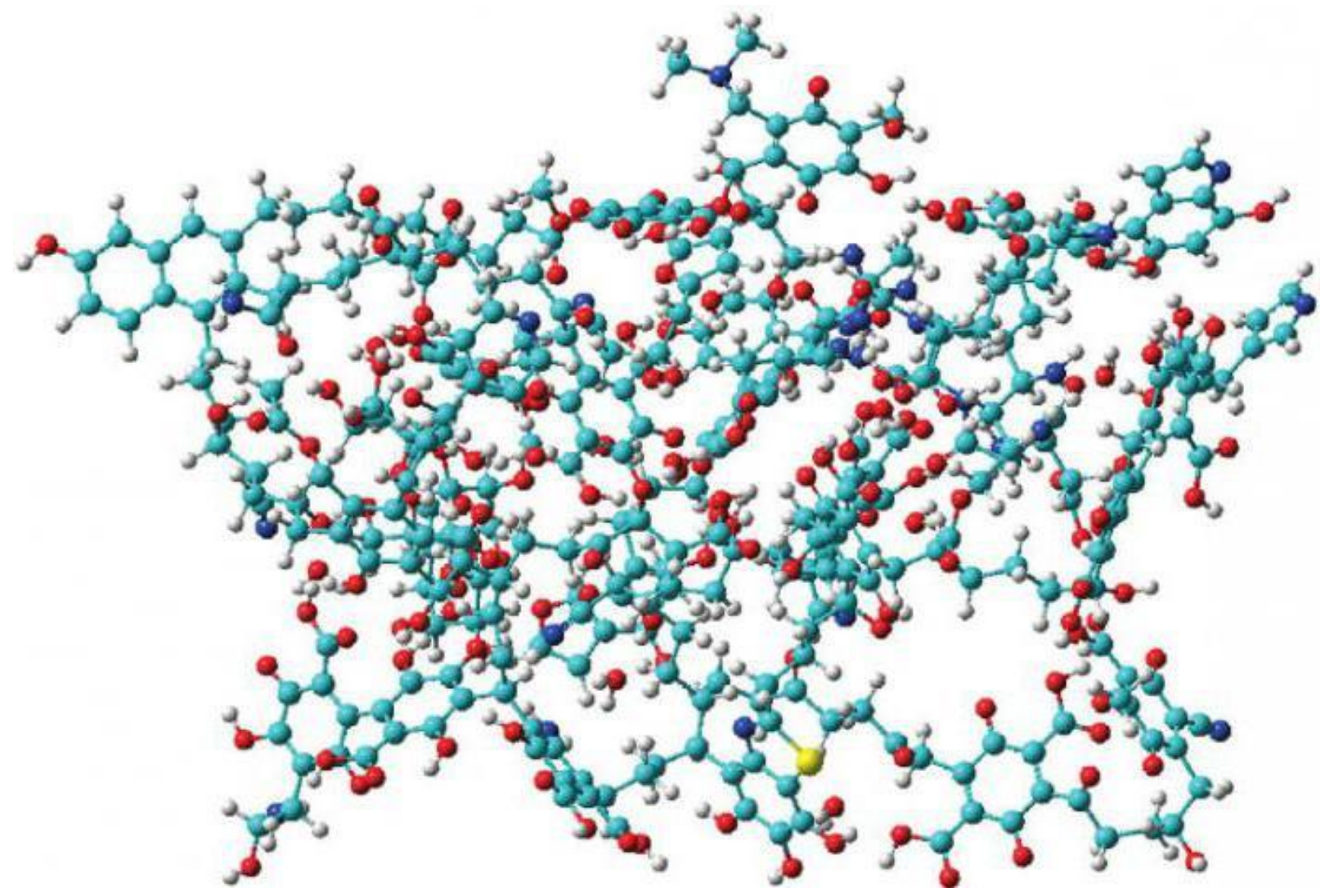

Рис. 5.7. Структура макромолекулы гуминовой кислоты

При этом отношение Н:C можно принять как показатель относительной доли ароматических группировок - структурных сегментов лигнина в молекуле, а отношение $\mathrm{N}: \mathrm{C}$ как степень развития процессов окисления полимеров целлюлозы, липидов, белков - основного поставщика мономеров для синтеза линейных макромолекул гуминовых кислот. Гипотеза механизма формирования гуминовых и фульвокислот остается единой.

Гуминовые кислоты - высокомолекулярные соединения с развитым длинноцепочечным гидрофобным радикалом (R) - Cn-Hm и большим количеством свободных полярных групп: -COOH, - OH, - NH. Соотношение длины неполярной гидрофобной части и количества свободных полярных групп в макромолекуле определяется гидрофильно-гидрофобным (ГГБ) балансом. Размер неполярного радикала, природа полярной группы, а также величина ГГБ влияют на устойчивость структуры ППК. Молекулярно-массовой 


\section{СТАБИЛИЗАЦИЯ СВОЙСТВ ТОПЛИВНО-ЭНЕРГЕТИЧЕСКИХ СИСТЕМ НА ОСНОВЕ ПРИРОДНЫХ И СИНТЕТИЧЕСКИХ ПОЛИМЕРОВ}

распределение (ММР) гуминовых кислот определяется фактором времени. Молодые гумусовых кислот, образованные в течение года, имеют гетерогенную структуру и $\quad$ MMP $50000 \ldots 60000$ в дерново-подзолистых $\quad$ и $40 \quad 000$ в черноземных почвах.

Свойства гуминовых кислот определяются элементарным составом, наличием различных форм азота, числом свободных функциональных групп, ароматических и гетероциклических группировок, растворимостью, гранулометрическим составом, реакционной способностью. В линейной макромолекуле (рис. 5.8) ароматические и гетероциклические группы соединены между собой предельными $-\mathrm{C}-\mathrm{C}-$ или непредельными $-\mathrm{C}=\mathrm{C}-$ углеродными связями в макромолекулу. При межмолекулярном взаимодействии активных свободных функциональных групп линейных макромолекул образуются связи: $-\mathrm{O}-,-\mathrm{N}-,-\mathrm{H}-,-\mathrm{CH}_{2}-$, соединяющие их между собой так называемыми мостиками.

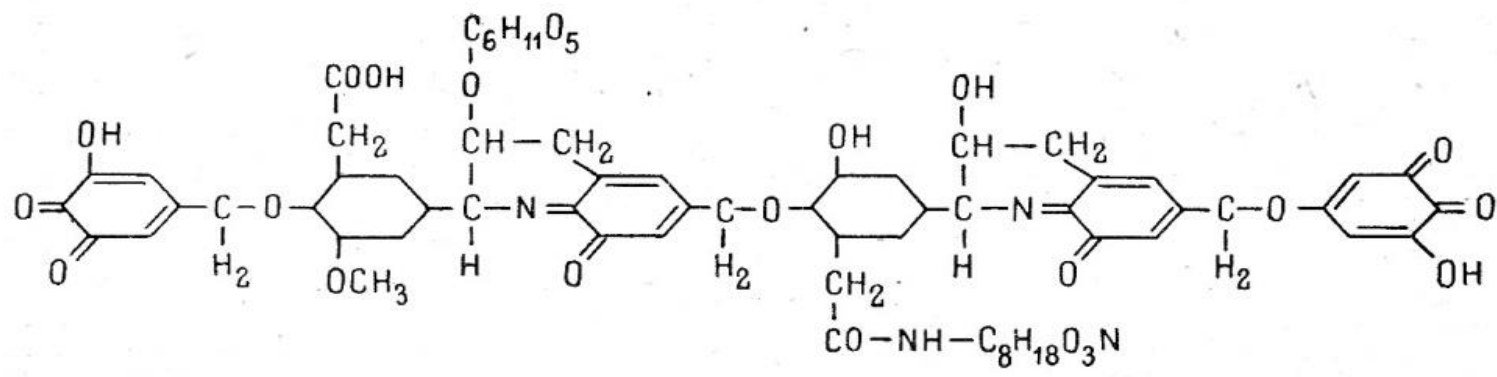

\section{Рис. 5.8. Структура линейных макромолекул гуминовых кислот}

Макромолекулы гуминовых кислот (ГК) в растворе образуют полидисперсную мицеллу (рис. 5.9), которая состоит из ядра (•) размером 16,5 нм, образованного межмолекулярными взаимодействиями гидрофобных лигнин-протеиновых сегментов (-) макромолекул, и оболочки, состоящей из упорядоченно ориентированных гидрофильных свободных функциональных групп (о): $-\mathrm{COOH},-\mathrm{OH},-\mathrm{NH}_{2},-\mathrm{OCH}_{3}, \mathrm{C}=\mathrm{O}$ вблизи ядра. 


\section{СТАБИЛИЗАЦИЯ СВОЙСТВ ТОПЛИВНО-ЭНЕРГЕТИЧЕСКИХ СИСТЕМ НА ОСНОВЕ ПРИРОДНЫХ И СИНТЕТИЧЕСКИХ ПОЛИМЕРОВ}

Упорядоченное расположение молекул в гидрофобном ядре мицеллы соответствует промежуточному состоянию между жидкостью и кристаллом непредельных углеводородов [106, с. 49].

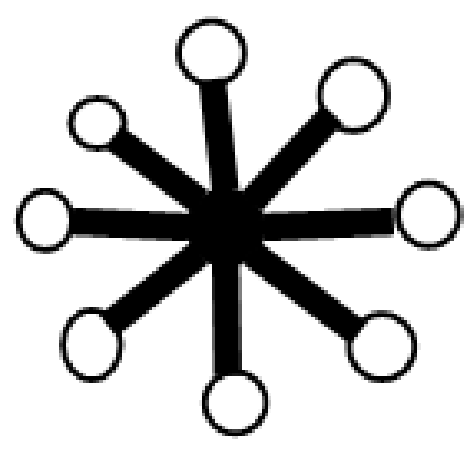

Рис. 5.9. Схематическое изображение сферической мицеллы: ядро- (•), гидрофобная часть (一), ( ( ) - гидрофильная часть макромолекул

Процесс образования мицелл с токи зрения квазихимической модели является обратимым и равновесным

$$
\sum v_{i} \cdot B_{i} \leftrightarrow M,
$$

где $B_{i}$ - макромолекулы ГК $i$-го сорта; $v_{i}$ - число агрегации; $M$ - мицелла.

При адсорбции мицелл гуминовых кислот на поверхности минеральных частиц глины протекают обменные ионные реакции с гидратированными ионами металлов или образуются водородные связи: ОН...О, NH...О, NH...N на границе раздела фаз с образованием тонких пленок на поверхности минеральных почвенных частиц. Часть промежуточных и гумусовых веществ, взаимодействуя с минеральной частью почвы (адсорбция) (окислами кремния, железа, алюмосиликатов) образуют органоминеральные коллоиды. Низкомолекулярные вещества: аминокислоты, спирты, альдегиды и другие участвуют в реакциях биосинтеза полимера лигнина [68, с. 757; 23, с. 118] (рис. 5.10) или проникают в пустоты кристаллической решетки минералов почвы - алюмосиликатов [71, с. 162]. 


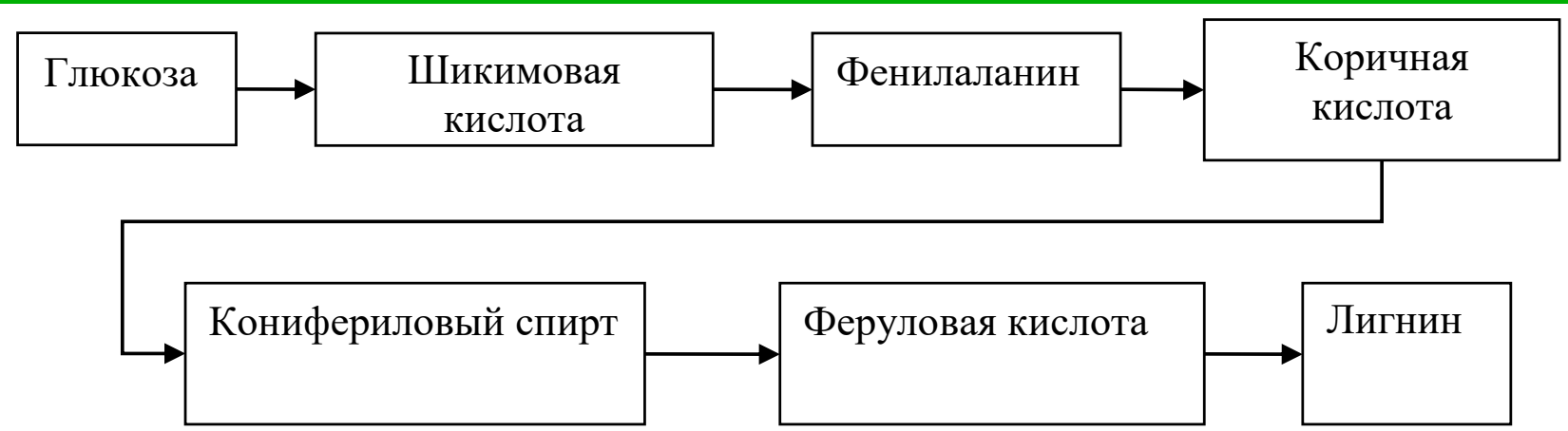

Рис. 5.10. Модель механизма биосинтеза лигнина в почве

При взаимодействии функциональных групп макромолекул гумусовых кислот с гидратированными молекулами минеральных солей почвенного раствора образуется в мицелле двойной электрический слой и возникает равновесный потенциал. С течением времени в почве происходит непрерывный процесс взаимодействия мицелл макромолекул гумусовых кислот с образованием органоминерального ППК. При выщелачивании горных пород в почве образуются минеральные соли и органоминеральные комплексы фульвокислот, которые способны мигрировать в гумусовом профиле почвы. Гуминовые кислоты аккумулируются в гумусе. Качественную характеристику почвенного гумуса определяют по содержанию растворимых в воде солей гуминовых кислот (гуматов), формирующих запас лабильных элементов питания и являющихся показателем доступности гумусовых веществ микроорганизмам. Образование гумусовых кислот возможно и в результате реакций поликонденсаций (А.Г. Турусов) ароматических соединений фенольного типа с аминокислотами с выделением в качестве побочных продуктов - воды, либо других низкомолекулярных веществ. При протекании реакций поликонденсации примерно $60 \ldots 70 \%$ образующихся полимерных веществ переходит в гумус. По всей видимости в природных экосистемах при гумификации имеют место оба механизма.

В обобщенном виде процесс гумификации представлен на рисунке 5.11 . Под действием ферментов живого вещества детрит в почве подвергается анаэробной или аэробной биоконверсии (гидролизу или окислению) с образованием биополимеров: углеводов, белков, липидов, лигнина, нуклеиновых кислот или мономеров. 


\section{СТАБИЛИЗАЦИЯ СВОЙСТВ ТОПЛИВНО-ЭНЕРГЕТИЧЕСКИХ СИСТЕМ НА ОСНОВЕ ПРИРОДНЫХ И СИНТЕТИЧЕСКИХ ПОЛИМЕРОВ}

Мономеры: амины, аминокислоты, карбоновые кислоты, спирты, фенолы, моносахариды, жирные кислоты частично расходуются на гумификацию и аккумулируются в гумусе, и частично при благоприятных климатических условиях на минерализацию мономеров до образования солей, кислот, газов. Аминокислоты быстро разлагаются почвенной микрофлорой при аммонификации до аммиака $\left(\mathrm{NH}_{3}\right)$, который при нитрификации трансформируется до нитратов $\left(\mathrm{NO}_{3}^{-}\right)$. Запас промежуточных веществ в почве непрерывно пополняется за счет биосинтеза микроорганизмами, корневых выделений растений (колины).

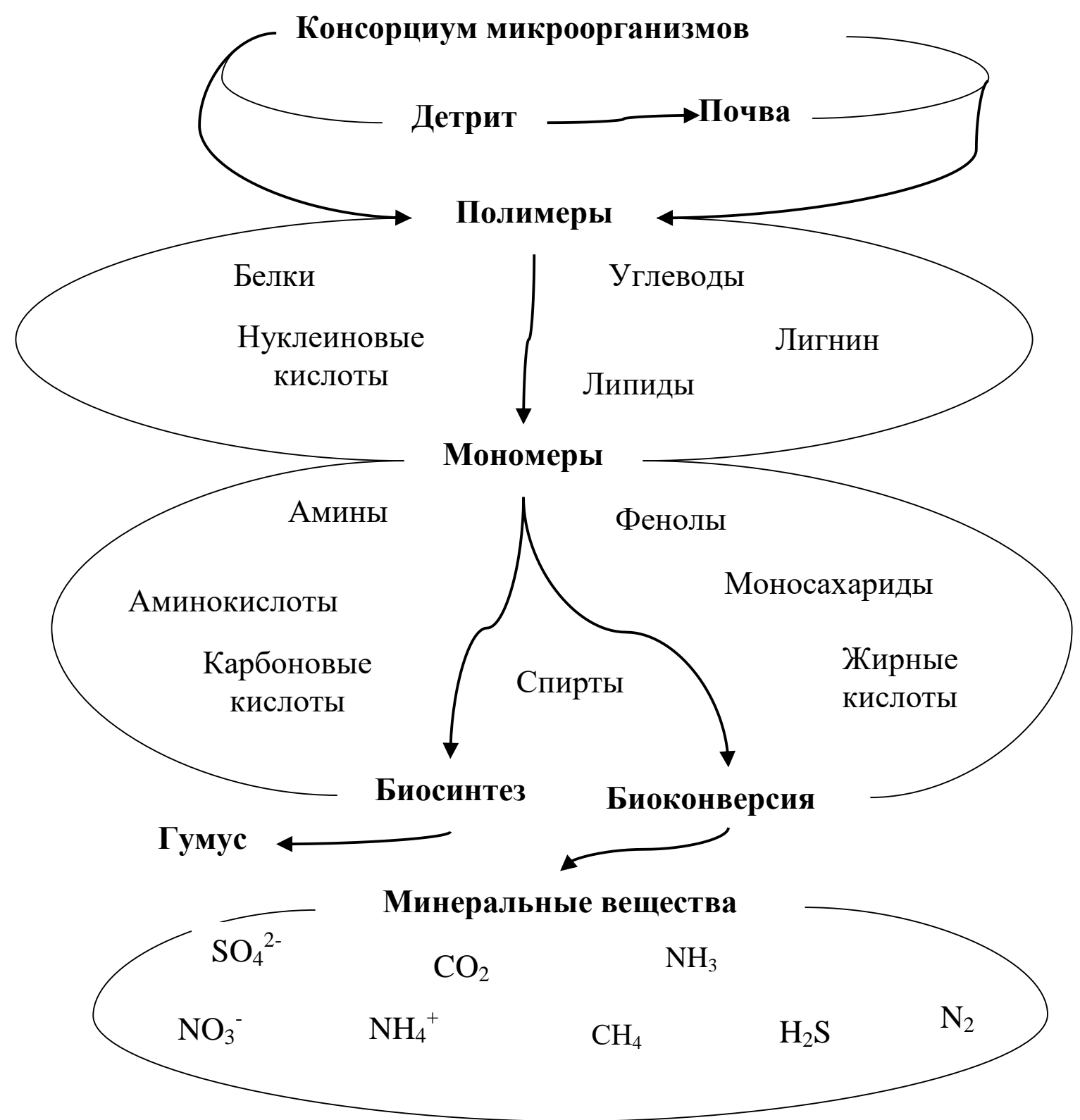

Рис. 5.11. Модель деструкции природных полимеров 


\section{СТАБИЛИЗАЦИЯ СВОЙСТВ ТОПЛИВНО-ЭНЕРГЕТИЧЕСКИХ СИСТЕМ НА ОСНОВЕ ПРИРОДНЫХ И СИНТЕТИЧЕСКИХ ПОЛИМЕРОВ}

Биосинтез может осуществляться в аэробных или анаэробных условиях. Низкомолекулярные карбоновые кислоты: щавелевая, янтарная, фумаровая, лимонная, малоновая, яблочная, масляная, уксусная, муравьиная образуются при аэробной ферментации углеводов. При анаэробной ферментации образуются спирты: метиловый, этиловый, пропиловый и другие, которые минерализуются до диоксида углерода $\left(\mathrm{CO}_{2},\right)$, метана $\left(\mathrm{CH}_{4}\right)$, сероводорода $\left(\mathrm{H}_{2} \mathrm{~S}\right)$ или меркаптана.

Целлюлоза расщепляется в природных условиях медленно бактериями, грибами, актиномицетами под действием целлюлаз из-за специфики строения природных волокон целлюлозы, которые пропитаны лигнином, восками, смолами. В анаэробных условиях целлюлоза разлагается бактериями рода Cytophaga, Cellvibrio, Cellulomans с образованием смеси низкомолекулярных органических кислот (уксусной, молочной, масляной, муравьиной) и спиртов. Наличие целлюлозно-лигниновых волокон в корнях травянистых растений лимитирует скорость его биологической деструкции.

Подвижные формы минеральных веществ:

$$
\mathrm{SO}_{4}{ }^{2-}, \mathrm{NO}_{2}{ }^{-}, \mathrm{NO}_{3}{ }^{-}, \mathrm{H}_{2}, \mathrm{NH}_{3}, \mathrm{H}_{2} \mathrm{O}, \mathrm{CO}_{2}, \mathrm{CH}_{4}, \mathrm{~N}_{2}, \mathrm{H}_{2} \mathrm{~S}
$$

вовлекаются в биотический круговорот экосистем и обеспечивают стабильность природных экосистем, продуктивность почв и фитоценозов, которые тесно взаимосвязаны и относятся к возобновляемым биоэнергетическим ресурсам, поскольку именно посредством живых организмов происходит гумификация природных отходов, накапливаются природные энергетические ресурсы нефти, и угля, сланцев, обеспечивающие человека продовольствием, топливом, строительными материалами, сырьем для многих видов промышленности. Древесная биомасса биосферы (около 200 млрд т в год) не только очищает атмосферный воздух, но и синтезирует кислород, который в свою очередь расходуется при окислении детрита и биосинтезе биополимеров. 


\section{2 Методология рекультивации техногенных почв}

Мониторинг плодородия почв Тверского региона показал, что большую часть посевных площадей России (78 млн. га) представляет дерновоподзолистые почвы. Массив черноземных почв достигает 1,53 млн. км², что составляет $48 \%$ от мировой площади черноземных почв. Длительное использование интенсивных технологий (химизация, механизация, мелиорация и другие) агропромышленным комплексом, нарушило механизм самовосстановления, трансформации, аккумуляции, миграции биогенных элементов и привело к снижению плодородия почв, повышению энергетической стоимости получаемой продукции [107 - 110].

Особую роль в формировании органического вещества подзолистых почв, согласно биохимической теории академика В.Р. Вильямса играют растения, аэробные процессы окисления и восстановления органических веществ, биогенный круговорот веществ [111, с. 24]. Регулирование почвенного плодородия дерново-подзолистых почв возможно с помощью агротехнических инструментариев: ежегодной вспашкой на 20 см, внесением извести, органических удобрений, введением в севооборот травопольной системой земледелия [71, с. 206], бобовых культур, использование их как зеленого удобрение (сидерат) для повышения урожайности сельскохозяйственных культур [112, с. 32]. Эти приемы культивирования почв повышают буферную емкость и $\mathrm{pH}$, сохраняют влагу ППК. Восстановление энергетического потенциала почв (гумуса) возможно и при использовании продуктов биоконверсии техногенных органогенных отходов в качестве удобрения для повышения урожайности культурных растений или при рекультивации техногенных почв с созданием нового плодородного слоя. 


\section{СТАБИЛИЗАЦИЯ СВОЙСТВ ТОПЛИВНО-ЭНЕРГЕТИЧЕСКИХ СИСТЕМ НА ОСНОВЕ ПРИРОДНЫХ И СИНТЕТИЧЕСКИХ ПОЛИМЕРОВ}

России ежегодно накапливается до 300 млн. тонн различных промышленных, сельскохозяйственных: солома, стебли, жмых, плодовые косточки, ореховая скорлупа и другие, а также до 50 млн. т бытовых органогенных отходов, которое можно использовать как вторичные возобновляемые энергетические биоресурсы для получения тепловой энергии (табл. 5.2) или удобрения (табл. 5.3). Незадействованные отходы сельскохозяйственной промышленности составляют $90 \%$ и $\quad 60 \%$ при промышленной деревопереработке древесины. Теплота сгорания целлюлозосодержащих отходов в два раза ниже теплоты сгорания каменного угля. Газификационные установки могут успешно применяться при переработке отходов деревообрабатывающих предприятий (гидролизный лигнин), зерноочистительных (солома, рисовая и подсолнечная шелуха, стебли хлопчатника и т.п.) или сельскохозяйственных предприятий для производства тепловой энергии (4,6-6,3 мДж) в районах, удаленных от электрических и газовых сетей $[93,94]$.

Таблица 5.2

Характеристика целлюлозосодержащих отходов в сравнении с каменным углем

\begin{tabular}{|l|c|c|c|}
\hline \multicolumn{1}{|c|}{ Сырье } & $\begin{array}{c}\text { Теплотворная способность, } \\
\text { мДж/кг }\end{array}$ & $\begin{array}{c}\text { Влажность, } \\
\%\end{array}$ & $\begin{array}{c}\text { Зола, } \\
\%\end{array}$ \\
\hline Каменный уголь & $25 \ldots 32$ & $1 \ldots 10$ & $0,5 \ldots 6$ \\
\hline Древесина & $10 \ldots 20$ & $10 \ldots 60$ & $0,2 \ldots 1,7$ \\
\hline Солома & $14 \ldots 16$ & $4 \ldots 5$ & $4 \ldots 5$ \\
\hline Рисовая шелуха & $13 \ldots 14$ & $9 \ldots 15$ & $15-20$ \\
\hline Хлопчатник & 14 & 9 & 12 \\
\hline Кукуруза & $13 \ldots 15$ & $10 \ldots 20$ & $2 \ldots 7$ \\
\hline
\end{tabular}

Промышленные конструкции газогенераторов просты и компактны, эффективны, экономичны (окупаются в течение $2 . .3$ лет). Затраты на 201 
оборудование составляют менее $1000 \$$ на 1 кВт получаемой электроэнергии. На выработку 1 кВт электроэнергии требуется примерно 1,3 ..1,8 кг рисовой шелухи (соломы) или 1,1..1,6 опилок (или лигнина).

Таблица 5.3

\section{Состав целлюлозосодержащего сырья}

(масс. \% от массы сухого вещества сырья)

\begin{tabular}{|l|c|c|c|c|}
\hline \multirow{2}{*}{ Вид сырья } & \multicolumn{3}{|c|}{ Химический состав сырья } & \multirow{2}{*}{ Зола } \\
\cline { 1 - 4 } & Целлюлоза & Лигнин & Пентоза & \\
\hline Солома & & & $19-30$ & \\
Пшеница & $34,8-49,2$ & 24,5 & $27,7-28,8$ & $4,6-5,5$ \\
Рожь & $40,4-49,3$ & 22,9 & 27,1 & $3,1--4,1$ \\
Рис & 42,9 & 17,9 & 15,3 \\
\hline
\end{tabular}

В составе древесины содержание лигнина больше, чем в многолетних травах, а в многолетних травах преобладает гемицеллюлоза. Соотношение этих веществ в биомассе зависит от генетических, биохимических или экологических факторов и предопределяет скорость их гумификации в почве и при переработке целлюлозосодержащих отходов. Содержание полимеров целлюлозы и лигнина, используемое при гумификации отходов при переработке первичного сырья - культурных растений представлено в таблице 5.3 [71, с.].

Биологические концепции образования гумуса, основанные на гипотезе синтеза и биосинтеза гумусовых веществ в почве, опираются на активизирующую деятельность почвенных микроорганизмов. Интенсивность гумусообразования в агроэкосистемах регулируется динамикой и химическим составом поступающих в почву органических остатков (надземной массой, подземной массой), гранулометрическим составом почвы и адсорбционной способностью ее минеральной составляющей. Остатки травянистой растительности богаты белками, углеводами и зольными элементами. Основная 


\section{СТАБИЛИЗАЦИЯ СВОЙСТВ ТОПЛИВНО-ЭНЕРГЕТИЧЕСКИХ СИСТЕМ НА ОСНОВЕ ПРИРОДНЫХ И СИНТЕТИЧЕСКИХ ПОЛИМЕРОВ}

часть их попадает непосредственно в почву в виде корней, их разложение происходит при тесном контакте с почвенными частицами в присутствии значительного количества микро и макроэлементов, активизируя деятельность почвенных микроорганизмов.

Эффективность гумификации органических отходов определяют по содержанию карбоксильных групп в гумусовых кислотах, то есть кислотному числу (КЧ) мг-экв. КОН/г (табл. 5.4). Содержание гуминовых кислот составляет при гумификации вегетативной массы клевера составляет 301,1 мг-экв. КОН/г, а при разложении корней многолетних трав 258,5 мг-экв. КОН/г. Эти данные свидетельствуют о преобладающей роли в накоплении гумуса вегетативной массы [71, с. 140].

Для черноземных почв КЧ составляет 375..530 мг•эКв. КОН/100г, для дерново-подзолистых или торфяных - 300...500 мг•экв. КОН/100г.

Таблица 5.4

\section{Элементарный состав продукта гумификации многолетних трав}

в пересчете сухую беззольную массу

\begin{tabular}{|c|c|c|c|c|c|c|c|c|}
\hline \multirow[t]{2}{*}{$\begin{array}{c}\text { Биомасса } \\
\text { Многолетних } \\
\text { трав }\end{array}$} & \multirow[t]{2}{*}{$\begin{array}{c}\text { Гумифи- } \\
\text { кация, } \\
\text { сут. }\end{array}$} & \multirow[t]{2}{*}{$\begin{array}{c}\text { Зола, } \\
\%\end{array}$} & \multicolumn{4}{|c|}{$\begin{array}{c}\text { Элементарный состав, } \\
\%\end{array}$} & \multicolumn{2}{|c|}{$\begin{array}{c}\text { Функциональные } \\
\text { группы, } \\
\text { мг экв./г }\end{array}$} \\
\hline & & & $\mathrm{C}$ & $\mathrm{H}$ & $N$ & $\mathrm{O}$ & $\mathrm{COOH}$ & $\mathrm{OH}$ \\
\hline & 15. & 1.6 & 8,10 & 4,50 &, 75 & 30 & & 323. \\
\hline корней & $15 \ldots 360$ & 2,22 & 55,93 & 3,20 & 3,2 & 35,5 & 258,5 & 305,75 \\
\hline
\end{tabular}

Использование научно обоснованных севооборотов, обработка почв с запахиванием сидератов, конструирование агроэнергетических фитоценозов многолетних трав, внесение минеральных и органических удобрений в почвенно-биотический комплекс агроэкосистем позволяют управлять накоплением гумуса $(0,5 \ldots 12 \%$ в год). Наиболее эффективными сидеральными культурами для повышения плодородия почв являются бобовые и мятликовые 
травостои [113 - 116]. Исследования гумификации органогенных отходов растительных остатков, подстилки, дернины, навоза в работах Л.Н. Александровой свидетельствуют о лимитирующей стадии биосинтеза гумусовых кислот (табл. 5.4). Содержание гумусовых веществ убывает в ряду органогенных отходах:

$$
\text { навоз > торф > дернина (дернина). }
$$

Содержание азота гумусовых кислот не является также постоянной величиной (табл. 5.5). При разложении корневой системы многолетних трав содержание азота в продукте гумификации составляет $3 \ldots 20 \%$, а при разложении вегетативной массы клевера $-1,64 \%$.

Скорость разложения протеинов наземной массы выше скорости разложения корней (рис. 5.12), как в аэробных, так и анаэробных условиях из-за особенностей морфологической структуры тканей в корнях, где белки находятся в комплексе с лигнином, что и тормозит скорость их минерализации.

\section{Таблица 5.5}

\section{Соотношение компонентов органической части гумуса}

В природных экосистемах

\begin{tabular}{|l|c|c|c|c|}
\hline \multicolumn{1}{|c|}{ Вещества } & Гумус & $\begin{array}{c}\text { Подстилка, } \\
\text { дернина }\end{array}$ & Торф & Навоз \\
\hline $\begin{array}{l}\text { исходных органических } \\
\text { остатков }\end{array}$ & $5,0 \ldots 20$ & $65 \ldots 90$ & $35 \ldots 85$ & $55 \ldots 80$ \\
\hline $\begin{array}{l}\text { промежуточные } \\
\text { продукты разложения }\end{array}$ & 1,0 & $1,0 \ldots 5,0$ & $1,1 \ldots 10$ & $2,0 \ldots 5,0$ \\
\hline гумусовые вещества & $80 \ldots 95$ & $5,0 \ldots 30$ & $10 \ldots 60$ & $15 \ldots 40$ \\
\hline
\end{tabular}




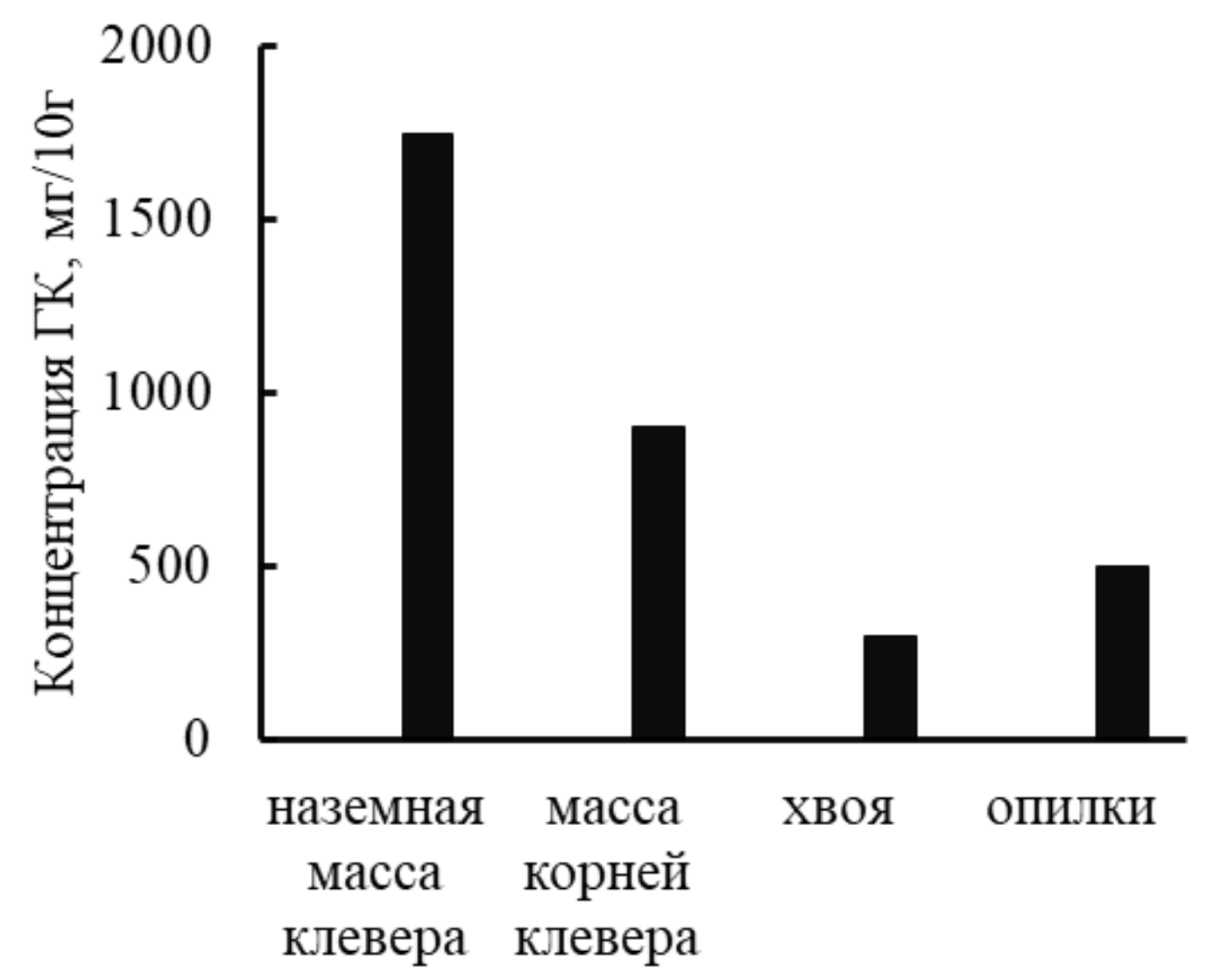

Рис. 5.12. Изменение концентрации гумусовых кислот (ГК) при биоконверсии растительных остатков

Кислая среда тормозит процесс гумусообразования. При распашке пласта козлятника восточного девятого года жизни в почву поступает от 27,7 до 30,2 т/га воздушно-сухих корневых остатков, а вместе с пожнивными остатками $28,5 \ldots 30,6$ т/га. [114, с. 93]. В то же время, коэффициент гумификации растительных остатков имеет тенденцию увеличения от вершины к подножию склона холма. В посевах клеверо-тимофеечной смеси энергетический потенциал пожнивно-корневых остатков возрастал при увеличении срока пользования многолетними травами. Так, энергия пожнивно-корневых остатков клеверо тимофеечной смеси 1 г.п. на 57 ГДж/га меньше трав 3 г.п. [113, с. 773].

Стабильность агроэнергетических фитоценозов многолетних трав во-многом определяется коэффициентом использования азота растениями из минеральных удобрений (рис. 5.13). 
Коэффициент использования азота из минеральных удобрений растениями не превышает 40\%. Остальное количество вносимого азота фиксируется в почве микрофлорой и безвозвратно теряется при денитрификации и вымывании грунтовыми водами. Биомасса сухого вещества микроорганизмов в годичном цикле почвообразования коррелирует с запасом гумуса. Применение изотопа азота ${ }^{15} \mathrm{~N}$ в многолетних луговых фитоценозах позволило достоверно выявить участие почвенного азота в питании растений на фоне внесения азотных удобрений, определить истинные коэффициенты использования азотных удобрений, определить потери на денитрификацию и вымывание [114, с. 93; 115].

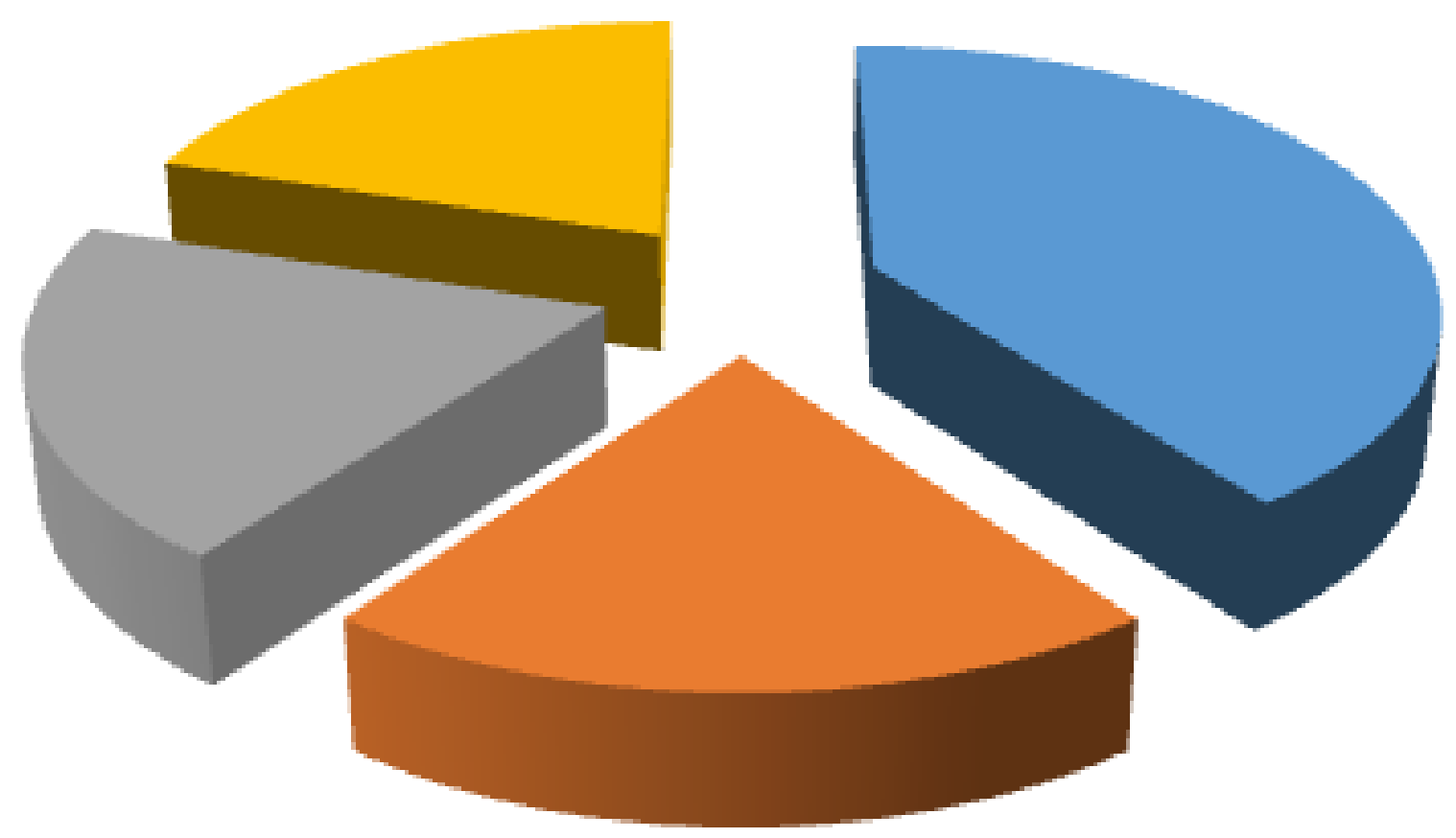

\section{растения \\ микрофлора}

\section{пинитрификация $\square$ вымывание}

Рис. 5.13. Распределение азота минеральных удобрений в почвенно-биотическом комплексе 


\section{СТАБИЛИЗАЦИЯ СВОЙСТВ ТОПЛИВНО-ЭНЕРГЕТИЧЕСКИХ СИСТЕМ НА ОСНОВЕ ПРИРОДНЫХ И СИНТЕТИЧЕСКИХ ПОЛИМЕРОВ}

Традиционный источник поступления органического вещества в пахотные дерново-подзолистые почвы, влияющий на гумусообразование органические удобрения, полученные компостированием навоза, торфонавозных смесей (ТМАУ), содержащих гумусовые кислоты [116, с. 3]. Расширить ассортимент органических удобрений, содержащих гумусовые вещества возможно при использовании химических [117, с.670] или биологических инструментариев [118] деструкции промышленных и агропромышленных отходов. Модификация гидролизного лигнина азотсодержащими солями повышает пористость органического удобрения, что позволяет сократить потребление воды растениями в среднем в 10 раз и увеличить урожайность сельскохозяйственных культур на $30 \ldots .50 \%$. $[117$, с.670]. Используя термофильные штаммы целлюлолитических микроорганизмов Clostridium thermocellum $u$ Streptomyces $s p$. возможно получить органическое удобрение из смеси почвы целлюлозосодержащих промышленных отходов - бумажный скоп и биокомпоста - смеси птичьего помета, навоза крупного рогатого скота, торфа и опилок; в соотношении 4:1:1 при влажности 60...65\% [118]. Недостатками данного способа гумификации являются необходимость предварительной стадии приготовления биокомпоста, стерилизации штаммов микроорганизмов и субстрата, длительные сроки гумификации отходов.

При внесении традиционных органических удобрений из десяти тонн вносимых в почву органических удобрений в вегетационный период лишь 0,3 тонны трансформируется в гумусовые кислоты, что объясняется лимитирующей стадией биоконверсии лигнина в почве, наличием в удобрениях семян сорных растений, патогенных микроорганизмов.

Использование эффективного консорциума микроорганизмов препарата «Тамир» при биоконверсии целлюлозосодержащих отходов [98] позволила в два три раза сократить сроки гумификации с получением высокоэффективной 


\section{СТАБИЛИЗАЦИЯ СВОЙСТВ ТОПЛИВНО-ЭНЕРГЕТИЧЕСКИХ СИСТЕМ НА ОСНОВЕ ПРИРОДНЫХ И СИНТЕТИЧЕСКИХ ПОЛИМЕРОВ}

гумифицированной почвой $[121$, с. 311$]$, которую можно рекомендовать при рекультивации техногенных почв, регулировании плодородия дерновоподзолистых почв и включении их в сельскохозяйственный оборот или декоративно-прикладное использование. Использование консорциума эффективных микроорганизмов усовершенствовать систему комбинированного производства тепловой и электрической энергии, разработать методологию утилизации полимерных отходов и сформулировать гипотезу рекультивации техногенных почв $[119$, с. 7]. В основе методологии лежат принципы безопасного и стабильного функционирования природных экосистем, мониторинга. При оценке загрязнения и плодородия почв использовали инновационные инструментарии биотестирования [120,с. 9].

Рекультивация техногенных почв с использованием стандартных инструментариев определены ГОСТ 17.5.1.02-85 и проводится в два этапа: технического и биологического. Технический этап рекультивации техногенных почв начинается с выравнивания рвов, впадин, терриконов с последующим нанесением плодородного слоя почвы Биологический этап - стабилизация качества новой почвы.

Для ускорения биологического этапа рекультивации техногенных почв предложено проводить с помощью эффективной гумифицированной почвы, полученной анаэробной ферментацией эффективными микроорганизмами

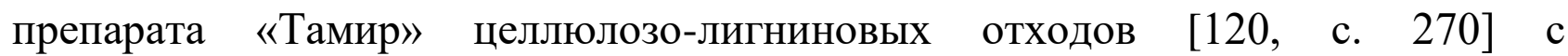
последующим посевом агроэффективных многолетних луговых трав.

Продуктивность почв оценивали по средневзвешенному выходу биомассы и продукции с единицы площади с учетом биомассы и продукции всех культур, входящих в структуру посевных площадей и биометрическим показателям качества тест растений [122, с. 13]. Многолетние исследования, проведенные в опытно-полевых условиях Тверской государственной сельскохозяйственной академии, рост и развитие корневой системы луговых 208 


\section{СТАБИЛИЗАЦИЯ СВОЙСТВ ТОПЛИВНО-ЭНЕРГЕТИЧЕСКИХ СИСТЕМ НА ОСНОВЕ ПРИРОДНЫХ И СИНТЕТИЧЕСКИХ ПОЛИМЕРОВ}

трав находится в зависимости от режима укоса и внесения удобрений. Наибольшая масса корней накапливается при двух укосах во всех режимах внесения минеральных удобрений. Фосфорно-калийный фон способствует увеличению корневой массы. Внесение азотных удобрений снижает ее количество, причем при распределении удобрений по укосам в большей степени. Наибольший коэффициент продуктивности наблюдался при двух укосах (табл. 5.6). Трехкратное использование травостоя сопровождается интенсивным вовлечением сахаров в обмен веществ. В варианте РК их содержание равнялось 5,2\%. Максимальное содержание сахара 8,9\% получено при полном минеральном удобрении. Распределение азота по укосам способствует накапливанию сахаров в корневой массе. Для восстановления продуктивности загрязненной почвы предложена модель биологической рекультивации техногенных почв (рис. 5.14).

Использование эффективного гумифицированного продукта биоконверсии техногенных целлюлозосодержащих отходов на биологическом этапе рекультивации ускорит адаптацию микроорганизмов к новым условиям, восстановление биологической активности техногенных почв, стабилизацию фитоценоза луговых многолетних трав. При внесении в техногенную почву эффективные микроорганизмы быстро ускорили посевную всхожесть семян луговых многолетних трав, улучшили условия формирования их корневой системы и защитные функции от болезней. 


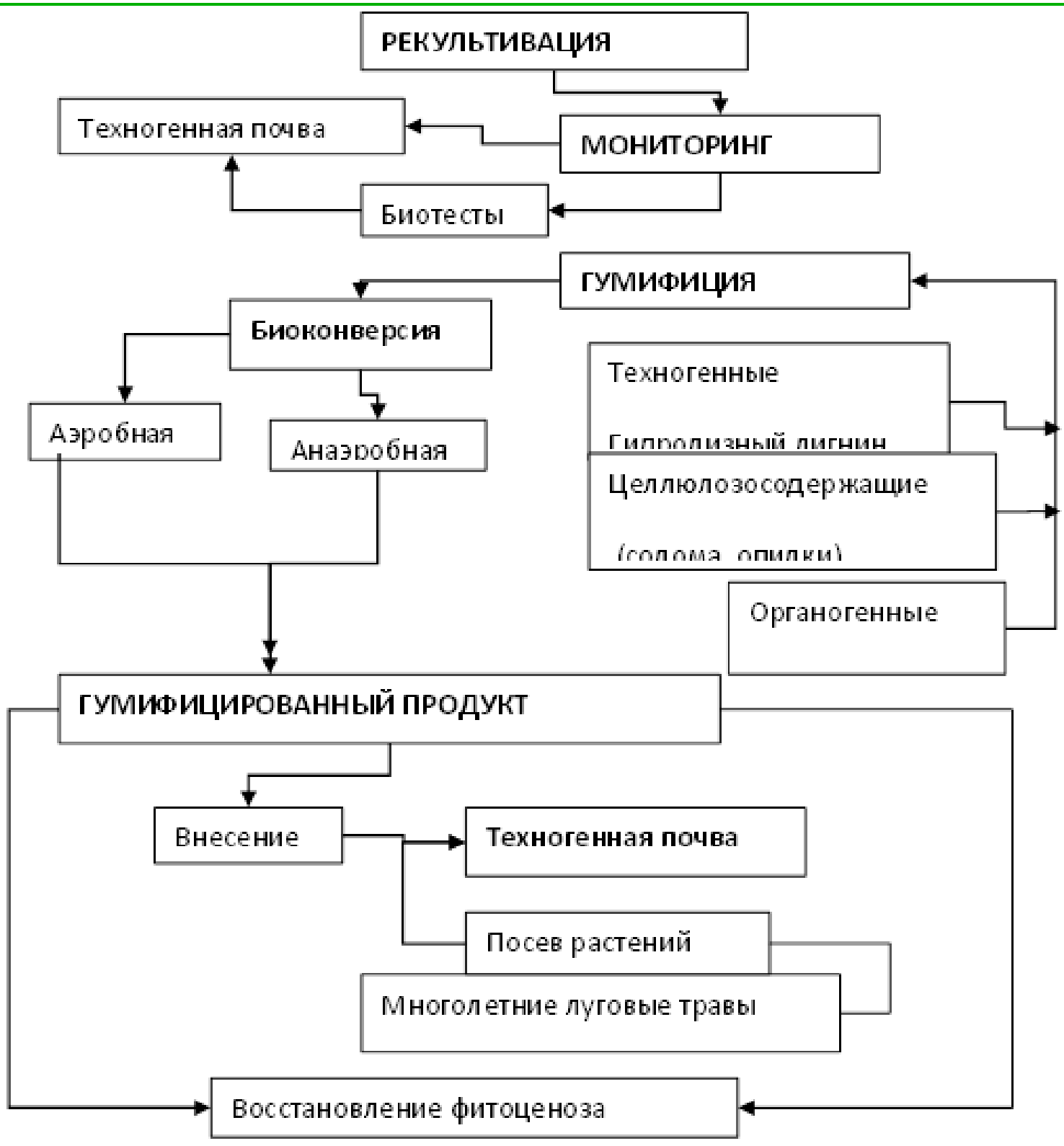

Рис. 5.14. Модель рекультивации техногенной почвы

Таблица 5.6

Характеристика массы корней луговых трав

\begin{tabular}{|c|c|c|c|}
\hline Удобрение & $\begin{array}{c}\text { Сухая масса, } \\
\text { ц с 1га }\end{array}$ & $\begin{array}{c}\text { Коэффициент } \\
\text { продуктивности }\end{array}$ & $\begin{array}{c}\text { Содержание } \\
\text { сахара, \% }\end{array}$ \\
\hline \multicolumn{4}{|c|}{ Двухукосное использование } \\
\hline РК & 99,8 & 0,82 & 7,1 \\
\hline NPК & 77,3 & 1,70 & 8,2 \\
\hline \multicolumn{4}{|c|}{ Трехукосное использование } \\
\hline РК & 98,7 & 0,80 & 5,2 \\
\hline NPК & 76,2 & 1,70 & 5,4 \\
\hline
\end{tabular}




Для эффективного использования злаковых $\quad$ травостоев при

рекультивации необходимо оптимизировать дозы внесения азотных удобрений в разные периоды вегетации. Возделывание энергетических растений бобовых и мятликовых трав эффективных при внесении гумифицированных продуктов биоконверсии ЦО позволит ускорить процесс гумификации, повысить продуктивность и снизить материальные и энергетические затраты на гумификацию почв, усовершенствовать биологический этап рекультивации почв, стабилизировать физико-химические свойства почв: водопроницаемость, воздухопроницаемость, буферную емкость ППК, повысить содержание гумуса, фитотоксичность почв. 


\section{ЗАКЛЮЧЕНИЕ}

Экологические проблемы по своей общественной значимости вышли на одно из первых мест, оттеснив даже опасность ядерной войны. Влияние человека на природу происходит как путем преобразования сложившихся в течение тысячелетий естественных систем, так и в результате загрязнения почв, и вод, и воздуха, что привело к резкому ухудшению состояния природы, и часто с необратимыми последствиями.

Одним из принципов достижения экологической безопасности является снижение выбросов, сбросов и отходов экономики, совершенствование методов и средств утилизации отходов.

Содержание монографии охватывает весьма широкий круг вопросов, связанных с концепцией создания экологически чистых энергоустановок. Основное внимание уделено методам стабилизации качества природных и техногенных экосистем. Рассмотрены известные классические и стабилизации физико-химических свойств синтетических полимерных систем.

Обращает на себя внимание, что в представленной рукописи достаточно полно охвачены как основополагающие методы утилизации синтетических и природных полимерных отходов, так и эффективные технологии биоконверсии твердых биополимерных отходов.

К новациям следует отнести разработку теоретических аспектов рекультивации техногенных почв. 


\section{Список литературы}

1. Пищевая химия / Нечаев А.П., Траубенгер С.Е., Кочетова А.А. [и др.] М.: ГИОРД, 2007. 640c.

2. Орлов, Д.С. Экология и охрана биосферы при химическом загрязнении. / Д.С. Орлов, Л.К. Садовникова, И.Н. Лозановская. М.: Высш.шк., $2002.334 \mathrm{c}$.

3. Салова Т.Ю. Основы экологии. Аудит техники и технологии. / Т.Ю. Салова, Н.Ю. Громова, В.С. Шкрабак [и др.]. Санкт-Петербург: Лань. 2004. $336 \mathrm{c}$.

4. Салова Т.Ю. Громова Н.Ю. Оценка техногенного риска энергетических систем / Т.Ю. Салова, Н.Ю. Громова // Международный журнал прикладных и фундаментальных исследований. 2018. № 2. С.165-169.

5. Громова, Н.Ю. Техногенные системы и экологический риск / Н.Ю. Громова, Т.Ю. Салова. - Санкт-Петербург: Политехнический университет, 2011.305 с.

6. Косаковская И.В. Стрессовые белки растений. / И.В. Косаковская. Киев, 2008.154 с.

7. Рассел, Э.Д. Почвенные условия и рост растений / Э.Д. Рассел. - М.: Иностранная литература, 1955. - 624 с.

8. Белов Г.В., Трусов Б.Г. Термодинамическое моделирование химически реагирующих систем / Г.В. Белов, Б.Г. Трусов. - Москва: МГТУ им. Н.Э. Баумана, (С) 2013. 96.

9. Бочкарев В.В. Оптимизация технологических процессов органического синтеза / В.В. Бочкарев. - Томск: Томский политехнический университет, 2010 .- 185 с.

10. Аносов В.Я., Озерова М.И., Фиалков Ю.Я. Основы физикохимического анализа / В.Я. Аносов, М.И. Озерова, Ю.Я. Фиалков. М.: Наука. 1976. $504 \mathrm{c}$. 


\section{СТАБИЛИЗАЦИЯ СВОЙСТВ ТОПЛИВНО-ЭНЕРГЕТИЧЕСКИХ СИСТЕМ НА ОСНОВЕ ПРИРОДНЫХ И СИНТЕТИЧЕСКИХ ПОЛИМЕРОВ}

11. Салова Т.Ю., Громова Н.Ю. Использование термодинамического метода в минимизации энергетических затрат / Т.Ю. Салова, Н.Ю. Громова // Вестник АПК Ставрополья. 2017. № 2 (26). С. 34-39.

12. Косенко В.В. Фальсифицированные лекарства - глобальная проблема / Косенко В.В., Быков А.В. Мешковский А.П. // Вестник росздравнадзора. 2009. №3. C 14-26.

13. Егоров Н.С. Основы учения об антибиотиках / Н.С. Егоров. - М.: Высшая школа. 1986.- 448 с.

14. Федеральный закон «Об обращении лекарственных средств» / № 61 Ф3 от 12 апреля 2010 г.

15. Таранцева, К.Р., Яхкинд, М.И. Анализ технологий синтеза 7-АЦК и выбор оптимальной безопасной промышленной технологии / К.Р. Таранцева, М.И. Яхкинд; М.: Научный мир, 2009. 210 с.

16. Громова Н.Ю., Лукеина М.Ю. Мониторинг безопасности антибиотиков / Н.Ю. Громова, М.Ю. Лукеина // Актуальные проблемы безопасности жизнедеятельности и экологии. Тверь: ТвГТУ. С.135-137.

17. Инженерная защита поверхностных вод от промышленных стоков / Д.А. Кривошеин, П.П. Кукин, В.Л. Лапин [и др.]. М.: Высшая школа. - 2003. $344 \mathrm{c}$.

18. ГОСТ 17.1.3.07-82. Охрана природы. Гидросфера. Правила контроля качества воды водоемов и водотоков.

19. Инженерная защита окружающей среды / Ю.А. Бирман, Н.Г. Вурдова. M.: ACB. - 2002. - 296 c.

20. Громова Н.Ю. Оценка эффективности гумифицированной почвы методом биотестирования / Н.Ю. Громова // Вестник Тверского государственного университета. Серия: Биология и экология. 2016. № 1. C. 135-141.

21. Громова Н.Ю. Оценка безопасности техногенных систем методом биотестирования / Н.Ю. Громова // Вестник Тверского государственного технического университета. 2016. № 2 (30). С. 75-79. 


\section{СТАБИЛИЗАЦИЯ СВОЙСТВ ТОПЛИВНО-ЭНЕРГЕТИЧЕСКИХ СИСТЕМ НА ОСНОВЕ ПРИРОДНЫХ И СИНТЕТИЧЕСКИХ ПОЛИМЕРОВ}

22. Фомин Г.С. Почва. Контроль качества по международным стандартам: справочник. / Г.С. Фомин, А.Г. Фомин - М.: Протектор, 2001. $300 \mathrm{c}$.

23. Салова Т.Ю., Громова Н.Ю. Термические методы переработки органических отходов. Источники возобновляемой энергии. СПб.: СПбГАУ. 2016. - 224 c.

24. ГОСТ Р ИСО 22030-2009 Качество почвы. Биологические методы. Хроническая фитотоксичность в отношении высших растений. - М.: Стандартинфом. 2010.

25. Мильчанова O.В. Тяжелые металлы в сельскохозяйственных растениях / О.В. Мельчакова, А.И. Иванов // Экология и промышленность России. - 2000. -№8 - c.38-40.

26. Ильин В.Б. Тяжелые металлы в системе почва - растение / В.Б. Ильин - Новосибирск: Наука. Сиб отд - ние, 1991. - 151 с.

27. Шведова Л.В. Миграция тяжелых металлов в системе «почва растение» / Л.В. Шведова, Т.А. Чеснокова, А.В. Невский // Инженерная экология. -2004. - №6. - c.46-53.

28. Якушина Н.И. Физиология растений / Н.И. Якушина, Е.Ю. Бахтенко М.: Владос 2005. - 463c.

29. Коган Н.Д., Рекунова М.М., Лазарева Г.А. Крылова И.А. Некоторые особенности нестабильности водных растворов алкидно-меламиновой смолы / Н.Д. Коган, М.М. Рекунова, Г.А. Лазарева, И.А Крылова // Лакокрасочные материалы и их применение. - 1974. - № 1. - С.10-14.

30. Тагер А.А. Физико-химия полимеров / А.А. Тагер. М.: Химия, 1968. $536 \mathrm{c}$.

31. Белоусов, В.П., Панов, М.Ю. Термодинамика водных растворов неэлектролитов / В.П. Белоусов, М.Ю. Панов. Л.: Химия, 1983. 264 с.

32. Громова Н.Ю. Теоретические аспекты минимизации опасностей лакокрасочных материалов // Актуальные проблемы безопасности жизнедеятельности и экологии. Тверь. 2016. С. 129-132. 
33. Gromova N.Yu. The roel of physico-chemical analysis in the stabilization of technological parameters / N.Yu Gromova // Sientific Discussien, 2017, v.1, № 6, p.30-34.

34. Игнатов И., Мосин О.В., Великов Б. Математические модели, описывающие структуру воды / И. Игнатов, О.В. Мосин, Б. Великов // Интернет журнал «Науковедение», ИГУПИТ, 2013, № 3, С.1-25.

35. Игнатов И.И., Мосин О.В. Структурные модели воды, описывающие циклические нанокластеры / И.И. Игнатов, О.В. Мосин // Нано- и микросистемная техника, М.: Новые технологии, 2014, № 3 (164), С. 47-56.

36. Кесслер Ю.М., Петренко В.Е., Лященко А.К. и др. Вода: структура, состояние, сольватация. Достижения последних лет / Ю.М.Кесслер, В.Е. Петренко, А.К. Лященко [и др.]. М.: Наука, 2003. 404 с.

37. Хан А.В., Власов В.А., Мышкин В.Ф. Анализ структуры и свойств разбавленных водных систем / А.В. Хан, В.А. Власов, В.Ф. Мышкин // Политематический сетевой электронный научный журнал Кубанского государственного аграрного университета, 2012, Выпуск № 81

38. Корсунский В.И., Наберухин Ю.И. Микрогетерогенное строение водных растворов неэлектролитов. Исследование методом дифракции рентгеновских лучей / В.И. Корсунский, Ю.И. Наберухин // Структурная химия, 1977, т.18, № 3

39. Ахунов Т.Ф., Салова Л.Е., Рахманкулов Д.Л. Инфрокрасные спектры воды в комплексах с триэтиламином и пиридином / Т.Ф. Ахунов, Л.Е. Салова, Д.Л. Рахманкулов //Основной органический синтез и нефтехимия. Ярославль, 1981, C.61-64.

40. Наберухин Ю.И., Рогов В.А. Строение водных растворов неэлектролитов (Сравнительный анализ термодинамических свойств водных и неводных двойных систем) // Успехи химии, 1971, т. 40, № 3, С. 369-384.

41. Фиалков Ю.Я. Двойные жидкие системы / Ю.Я. Фиалков. Техника, 1969. - $220 \mathrm{c}$. 


\section{СТАБИЛИЗАЦИЯ СВОЙСТВ ТОПЛИВНО-ЭНЕРГЕТИЧЕСКИХ СИСТЕМ НА ОСНОВЕ ПРИРОДНЫХ И СИНТЕТИЧЕСКИХ ПОЛИМЕРОВ}

42. Белоусов, В.П., Панов, М.Ю. Соколова Е.П., Смирнова Н.А. Межмолекулярные взаимодействия. Основные понятия / Е.П. Соколова, Н.А. Смирнова, Санкт-Петербург, 2008. 226 с.

43. Григорьев В.Ю., Громова Н.Ю. Свойства и структура водноорганических систем с низкомолекулярными компонентами / В.Ю. Григорьев, Н.Ю. Громова // Успехи химии, 1971, т.40, № 3, С. 369-384.

44. Григорьев В.Ю., Громова Н.Ю. Свойства и структура водноогранических систем с низкомолекулярными компонентами / В.Ю. Григорьев, Н.Ю. Громова // Физико-химическая механика дисперсных систем материалов. Киев: Наукова Думка. 1983, Ч.2, С.283.

45. Громова Н.Ю., Григорьев В.Ю. Принципы выбора низкомолекулярных компонентов водоразбавляемых лакокрасочных материалов / Н.Ю. Громова, В.Ю. Григорьев // Проблемы химии и технологии прогрессивных лакокрасочных материалов, Ярославль, 1990, С.90.

46. Язов А.Н. Изучение молекулярных взаимодействий органических растворителей с водой при производстве лакокрасочных материалов / А.Н. Язов // Технико-технологические проблемы сервиса, 2009, № 8, С.55-59.

47. Альдерс Л. Жидкостная экстракция / Л. Альдерс. М.: Иностранная литература, 1954. - 216 с.

48. Трейбал Р. Жидкостная экстракция / Р. Трейбал. М.: Химия, 1966. $724 \mathrm{c}$.

49. Громова, Н.Ю. Изучение фазовых равновесий жидкость-жидкость в системах вода-амин-полярный органический растворитель / В.Ю. Григорьев, А.М. Кунин, Н.Ю. Громова. Деп. В ВИНИТИ Калинин,1982, № 4936.

50. Салова Т.Ю., Громова Н.Ю. Теоретические аспекты изменения реологических свойств лакокрасочных материалов для судовых конструкций / Т.Ю. Салова, Н.Ю. Громова // Итоги науки. Выпуск 41. - Избранные труды Всероссийской конференции по проблемам науки и технологий. - М.: РАН, 2019.- 233 c. 


\section{СТАБИЛИЗАЦИЯ СВОЙСТВ ТОПЛИВНО-ЭНЕРГЕТИЧЕСКИХ СИСТЕМ НА ОСНОВЕ ПРИРОДНЫХ И СИНТЕТИЧЕСКИХ ПОЛИМЕРОВ}

51. Григорьев В.Ю., Громова Н.Ю., Коган Н.Д. Влияние фазового состояния на физико-химические свойства покрытий на основе водоразбавляемого олигоэфира ВПФСинА / В.Ю. Григорьев, Н.Ю. Громова, Н.Д. Коган // Лакокрасочные материалы и их применение, 1986, № 3, С. 42-46.

52. Способ получения пленкообразующего вещества. 1992. / Григорьев В.Ю., Громова Н.Ю. // Пат. РФ № 1754755.

53. Яминский В.В., Пчелин Е.А., Амелина Е.Д. Щучин. Коагуляционные контакты в дисперсных системах. М.: Химия, 1982. 185 с.

54. Фридрихсберг Д.А. Курс коллоидной химии. - М.: Химия. 1984.$368 \mathrm{c}$.

55. Баранов Н.А. Определение оптическими методами температуры пламени и содержания сажи в цилиндре дизеля / Н.А. Баранов // Труды ЦНИДИ, Л., 1978, вып. 74, С. 58-64.

56. Салова Т.Ю. Экологический мониторинг окружающей среды при эксплуатации автотракторной техники / Т.Ю. Салова. - С-П.: Индикатор, 1998. $-80 \mathrm{c}$.

57. Салова Т.Ю. Моделирование и исследование процессов образования оксидов азота дизелей / Т.Ю. Салова. - С-П.: Индикатор, 1998, 80 с.

58. Физическая химия / К.С. Краснов, Н.К. Воробьев, И.Н. Годнев и др. Под редакцией К.С. Краснова // В 2 книгах. Кн.1 Термодинамика: учебник для вузов. М.: Высшая школа, 2001. 512 с.

59. Белов Г.В., Трусов Б.Г. Термодинамическое моделирование химически реагирующих систем / Г.В. Белов, Б.Г. Трусов. - Москва: МГТУ им. Н.Э. Баумана, (С) 2013. - 96 с.

60. Бочков М.В., Ловачев Л.А., Четверушин Б.И. Химическая кинетика образования оксидов азота при горении / М.В. Бочков, Л.А. Ловачев, Б.И. Четверушин. - М.: Наука, 1974, 146 с.

61. Зельдович Я.Б. Садовников П.Я., Франк-Каменецкий Л.А. Окисление азота при горении / Я.Б. Зельдович, П.Я. Садовников, Л.А. Франк-Каменецкий. - М.: Наука, 1974, 146 с. 


\section{СТАБИЛИЗАЦИЯ СВОЙСТВ ТОПЛИВНО-ЭНЕРГЕТИЧЕСКИХ СИСТЕМ НА ОСНОВЕ ПРИРОДНЫХ И СИНТЕТИЧЕСКИХ ПОЛИМЕРОВ}

62. Салова Т.Ю., Громова Н.Ю. Использование термодинамического метода в минимизации энергетических затрат / Т.Ю. Салова, Н.Ю. Громова // Вестник АПК Ставрополья. 2017. № 2 (26). С. 34 - 39.

63. Гаев Ф.Ф., Шканов С.И. Оптимизация обращения с бытовыми отходами в муниципальных образованиях ФБУ «НИЦПУРО» / Ф.Ф. Гаев, С.И. Шканов // Твердые бытовые отходы. - 2021, №5(71). С. 8-13.

64. Пилунов Г.А., Михитарова 3.А., Цейтлин Г.М. Переработка отходов полиэтилентерефталата / Г.А. Пилунов, 3.А. Михитарова, Г.М. Цейтлин // Химическая промышленность. - 2001, № 6. - С. 22-26.

65. Иванкин А.Н. И Переработка органических отходов: учебное пособие / А.Н. Иванкин. А.Д. Неклюдов, С.М. Тарасов, Ю.Н. Жилин. - М.: ГОУ ВО МГУЛ, 2016. - 400 с.

66. Неклюдов А.Д., Иванкин А.Н. Экологическая биоэнергетика на основе анаэробного разложения органических отходов / А.Д. Неклюдов, А.Н. Иванкин // Экологические системы и приборы. - 2006, № 7, С. 33-44.

67. Бойлс Д. Биоэнергия: технология, термодинамика, издержки / Д. Бойлс.- М.: Агропромиздат, 1987.- 152 с.

68. Браунс, Ф.Э., Браунс Д.А. Химия лигнина / Ф.Э. Браунс, Д.А. Браунс. - М.: Лесная промышленность, 1964. - 855 с.

69. Фенгел Д., Вегенер Г. Древесина: химия, ультраструктура, реакции. / Д. Фенгел, Г. Вегенер. М.: Лесная промышленность 1988. 512 с.

70. Крутов С.М., Грибков В.И.,Зарубин М.Я. Изучение строения и свойств промышленных гидролизных лигнинов / С.М. Крутов, В.И., Грибков, М.Я. Зарубин // Известия СПбГЛТА.Санкт-Петербург. 2007. Вып.179. C. 201-210.

71. Александрова Л.Н. Органическое вещество почвы и процессы его трансформации / Л.Н. Александрова. Л.: Наука, 1980. - 288 с.

72. Способ получения топлива из лигнина 1999 / Нижегородцев В.И., Нижегородцева С.В., Нижегородцева Т.В., Торопова Л.В. // Пат. РФ № 2129142. 


\section{СТАБИЛИЗАЦИЯ СВОЙСТВ ТОПЛИВНО-ЭНЕРГЕТИЧЕСКИХ СИСТЕМ НА ОСНОВЕ ПРИРОДНЫХ И СИНТЕТИЧЕСКИХ ПОЛИМЕРОВ}

73. Грасси Н., Скот Дж. Деструкция и стабилизация полимеров / Н. Грасси, Дж. Скот. - М.: Мир, 1988. - 246 с.

74. Мадорский С. Термическое разложение органических полимеров / С. Мадорский. - М.: Мир, 1967. 328 с.

75. Сурков А.А., Балабенко Н.А. Глушанкова И.С. Утилизация полимерных отходов полипропилена и поликарбоната с получением углеродных сорбентов / А.А. Сурков, Н.А. Балабенко, И.С. Глушанкова // Вестник ПНИТУ. Урбанистика. - 2012, № 1, С. 89 - 96.

76. Гофтман М.В. Прикладная химия твердого топлива / М.В. Гофтман. М.: Металлургиздат, 1963. 597 с.

77. Анискин В.И. Топка на растительных отходах: разработка, испытание, расчет, использование //Энергообеспечение и энергосбережение в сельском хозяйстве. -Ч.4. - М., 2003. -С. 260-270.

78. Сергеев, В.В. Нетрадиционные и возобновляемые источники энергии. Часть 1. Возобновляемые источники энергии /Л.В. Зысин, В.В. Сергеев: Учеб. пособие. - СПб.: Политехн. ун-т, 2008. - С. 192.

79. Салова Т.Ю. Молчанов О.А. Анализ перспективных методов и схем использования процессов газификации в современной энергетике: Мат 7-й Всероссийской научно молодежной школы с международным участием «Возобновляемые источники энергии». - М.: МГУ, 2010. - С. 241-244.

80. Сульман Э.М., Громова Н.Ю., Тимофеев А.Г. Особенности термической деструкции вторичного полиэтилентерефталата / Э.М. Сульман, Н.Ю. Громова, А.Г. Тимофеев // Известия Санкт-Петербургского аграрного университета. 2006. № 2. С. 111-115.

81. Способ получения комплексной битум-полимерной композиции 2009 / В.А. Миронов, Э.М. Сульман, В.А. Кукушкин // Пат. РФ. № 2281963.

82. Полимерная композиция 1980 / Г.Я. Зальянц, Н.В. Губко, В.Р. Горбунова // Пат. РФ. № 765306.

83. Шкадин И.М., Громова Особенности технического регулирования утилизации полимерных отходов / И.М. Шкадин, Н.Ю. Громова // Актуальные 220 
проблемы безопасности жизнедеятельности и экологии. Тверь. 2015. C. 381-384.

84. Селиванов А.С. Комплексная переработка целлюлозосодержащих отходов лесоперерабатывающих и сельскохозяйственных предприятий на основе биоконверсии / А.С. Селиванов // Биотехнология на рубеже веков: проблемы и перспективы. Киров, 2001. С. 89-91.

85. Громова Н.Ю. Экологические аспекты утилизации целлюлозосодержащих отходов / Н.Ю. Громова // Вестник Тверского государственного технического университета. - 2015. № 1. (27). С. 40 - 43.

86. Емцев В.Т., Мишустин Е.Н. Микробиология / В.Т. Емцев, Е.Н. Мишустин.- М.: Дрофа, 2005.- 445 с.

87. Тюкавкина Н.А., Бауков Ю.И. Биоорганическая химия / Н.А. Тюкавкина, Ю.И. Бауков. - М.: Дрофа. 2005.- 542 с.

88. Промышленная микробиология / 3.А.Аркадьева [и др.]. М.: Высш.шк. 1989. - $688 \mathrm{c}$.

89. Гофтман М.В. Прикладная химия твердого топлива / М.В. Гофтман. М.: Металлургиздат, 1963. - 597 с.

90. Юкельсон И.И. Технология основного органического синтеза / И.И. Юкельсон. М.: Химия, 1968. - 848 с.

91. Латышев В.П., Мельник С.В. Технология получения горючего газа из бурых углей в газогенераторе кипящего слоя / В.П. Латышев, С.В. Мельник // Вестник ИрГТУ, 2004, № 3 (19), С. 115 - 117.

92. Способ получения газа из торфа 2002 / А.Е. Афанасьев, Э.М. Сульман, А.Е. Усанов, О.С. Мисников // Пат. РФ. № 2185418.

93. Голубкович А.В., Курбанов К.К. Сжигание растительных отходов во взвешенном слое / А.В. Голубкович, К.К. Курбанов // Энергообеспечение и энергосбережение в сельском хозяйстве. -Ч.4. - М., 2003. - С. 271-276.

94. Газогенератор. 2013 / Т.Ю. Салова, О.А. Молчанов // Пат. РФ. № 2497582 . 


\section{СТАБИЛИЗАЦИЯ СВОЙСТВ ТОПЛИВНО-ЭНЕРГЕТИЧЕСКИХ СИСТЕМ НА ОСНОВЕ ПРИРОДНЫХ И СИНТЕТИЧЕСКИХ ПОЛИМЕРОВ}

95. Салова Т.Ю. Молчанов О.А. Энергетические комплексы с использованием газогенерации твердого топлива / Т.Ю. Салова, О.А. Молчанов // Известия Санкт-Петербургского государственного аграрного университета. 2011. № 22. - С. 331-336.

96. Громова Н.Ю., Косивцов Ю.Ю., Сульман Э.М. Технология синтеза и биосинтеза биологически активных веществ / Н.Ю. Громова, Ю.Ю. Косивцов, Э.М. Сульман // Учебное пособие. Тверь: ТвГТУ, 2006. - 84 с.

97. Громова Е.А., Громова Н.Ю., Салова Т.Ю. Методология рационального использования природных ресурсов / Е.А. Громова, Н.Ю. Громова, Т.Ю. Салова // Международный журнал экспериментального образования. 2017. № 3-1. С. 55 - 57.

98. Способ получения гумифицированной почвы. 2013 / Т.Ю. Салова, Н.Ю. Громова, Е.А. Громова // Пат. РФ. №2508281.

99. Салова Т.Ю., Громова Н.Ю., Громова Е.А. Моделирование биоконверсии твердых отходов и получение биогаза / Т.Ю. Салова, Н.Ю. Громова, Е.А. Громова // Известия Международной акадении аграрного образования. 2013. № 19. С. 25 - 30.

100. Громова Н.Ю. Усовершенствование технологии гумификации вторичного сельскохозяйственного сырья / Н.Ю. Громова // Научноинновационная деятельность в агропромышленном комплексе. Минск.: БГИТУ. 2011. Часть 1. С. 133 - 135.

101. Громова Н.Ю., Салова Т.Ю., Тюлин А.В. Экологические аспекты управления гумификацией почв Тверского региона / Н.Ю. Громова, Т.Ю. Салова, В.А. Тюлин // Международный журнал экспериментального образования. 2017. № 1. С. 138 -140.

102. В.Ф. Вальков, К.Ш. Казеев, С.И. Колесников. - М.: ИКЦ «МарТ. 2006. - $496 \mathrm{c}$.

103. Гришина Л.А. Гумусообразование и гумусное состояние почв / Л.А. Гришина. - М.: МГУ. 1986. - 244 с. 


\section{СТАБИЛИЗАЦИЯ СВОЙСТВ ТОПЛИВНО-ЭНЕРГЕТИЧЕСКИХ СИСТЕМ НА ОСНОВЕ ПРИРОДНЫХ И СИНТЕТИЧЕСКИХ ПОЛИМЕРОВ}

104. Никитин В. М., Оболенская А. В., Щеголев В. П. Химия древесины и целлюлозы / В.М. Никитин, А.В. Оболенская. В.П. Щеглов. М.: Лесная промышленность, 1978. - 368 с.

105. Фенгел Д., Вегенер Г. Древесина: химия, ультраструктура, реакции. / Д. Фенгел, Г. Вегенер. М.: Лесная промышленность 1988. 512 с.

106. Сульман М.Г. Громова Н.Ю., Сульман Э.М. Физико-механические свойства сырья и готовой продукции пищевых производств / М.Г. Сульман, Н.Ю. Громова, Э.М. Сульман. Тверь: Тверской государственный технический университет. 2016. - 104 с.

107. Ковалев Н.Г. Баланс гумуса в агроландшафтном земледелии Ковалев Н.Г., Тюлин В.А., Иванов Д.А., Сутягин В.П. // Бюллетень ВИУА. 2003. -№119. - С.77-78.

108. Тюлин В.А. Плодородие почвы и продуктивность зерновых культур в звене севооборота с козлятником восточным. / В.А. Тюлин, А.Г. Кобзин А.М. Бакланов, Н.Н. Иванова// Земледелие. 2008. №5. С. 22-23.

109. Фирсов С.А. Состояние плодородия почв Тверской области / С.А. Фирсов // агрохимический вестник. 2009. № 5. С. 1 -3.

110. Фирсова Е.А., Фирсов С.С. Мониторинг земель сельскохозяйственного назначения Тверской области по основным показателям плодородия: обоснование динамики и оценка потенциала / Е.А. Фирсова, С.С. Фирсов // Плодородие. 2018. № 6 (105). - С. 39 - 44.

111. Наумов В.Д. Научное наследие академика В.Р. Вильямса в почвоведении / В.Д. Наумов // Известия ТСХА. 2014. Вып. 1. С. 16 - 26.

112. Салова, Т.М. Основная обработка почвы и урожай / Т.М. Салова, Ю.С. Адомяко// Земледелие. 1985. - № 7. - С. 31-32.

113. Иванов Д.А. Энергетический потенциал посевов клеверотимофеечной смеси / Д.А. Иванов, В.П. Сутягин, В.А.Тюлин // Международный журнал прикладных и фундаментальных исследований. -2016. -№ 5-5. - С 771775. 


\section{СТАБИЛИЗАЦИЯ СВОЙСТВ ТОПЛИВНО-ЭНЕРГЕТИЧЕСКИХ СИСТЕМ НА ОСНОВЕ ПРИРОДНЫХ И СИНТЕТИЧЕСКИХ ПОЛИМЕРОВ}

114. Тюлин В.А. Повышение эффективности удобрений в условиях экологизации земледелия. Тюлин В.А., Сутягин В.П., //Успехи современного естествознания. - 2016- № 11. - С. 91-95.

115. Филимонов Д.А. Азотные удобрения на сенокосах и пастбищах / Д.А. Филимонов. М.: Агропромиздат. 1985. - 176 с.

116. Ковалев Н.Г. Основные направления совершенствования технологических средств производства удобрений путем ускоренной биоконверсии органического сырья, получаемого на предприятиях агропромышленного комплекса // Н.Г. Ковалев. Вестник ВНИИМЖ, 2012, №4 (8), C. 3-12.

117. Комаров А.А. Моделирование трансформации гидролизного лигнина и выделение лигно-гуминовых кислот / А.А. Комаров // Почвоведение. 2005. № 6. С. $664-671$.

118. Способ получения органического удобрения путем утилизации целлюлозосодержащих промышленных отходов. 2005 / О.Д. Сидоренко, В.П. Земцов, Н.В. Голубцов // Пат. РФ. № 2257366.

119. Gromova N. Yu., Tyulin V.A. Modern instruments for stabilizing soil fertility / N. Yu. Gromova, V.A. Tyulin // Znanstvena misel journal. - Slovenia . 2017. - №5. - VOL.1. - c.4-8.

120. Громова Н.Ю. Влияние гумифицированного продукта на рост и развитие тест растений в техногенных системах / Громова Н.Ю. // Энергетический вестник Санкт-Петербургского аграрного университета. СанктПетербург. 2010. С. 259-272.

121. Громова Е.А., Салова Т.Ю. Разработка метода биоконверсии твердых отходов для получения возобновляемых энергетических ресурсов / Е.А. Громова, Т.Ю. Салова // Известия Санкт-Петербургского государственного аграрного университета. 2012. № 27. С. 307-312.

122. Громова Н.Ю. Биотестирование объектов окружающей среды / Н.Ю. Громова. Тверь: Тверской государственный технический университет. 2009. $-28 \mathrm{c}$. 
НАУЧНОЕ ИЗДАНИЕ

Салова Тамара Юрьевна

Громова Нина Юрьевна

\section{СТАБИЛИЗАЦИЯ СВОЙСТВ ТОПЛИВНО-ЭНЕРГЕТИЧЕСКИХ СИСТЕМ НА ОСНОВЕ ПРИРОДНЫХ И СИНТЕТИЧЕСКИХ ПОЛИМЕРОВ}

\section{Монография}

Редактор И. И. Ивановская

Подписано в печать 10.09.2021. Формат 60x85 1/16.

Бумага офсетная. Усл. печ. л. 12,96.

Тираж 500 экз.

МЦНП «Новая наука»

185002 , г. Петрозаводск

ул. С. Ковалевской д.16Б помещ. 35, 185002.

office@sciencen.org

https://sciencen.org/

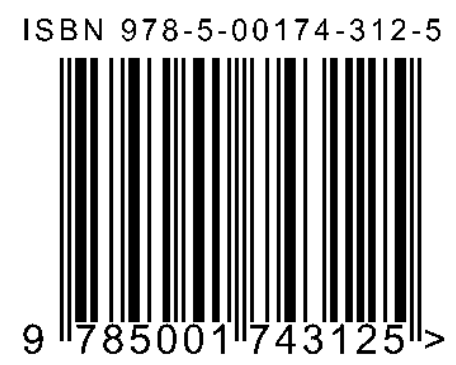

